University of Louisville

ThinkIR: The University of Louisville's Institutional Repository

Electronic Theses and Dissertations

$12-2005$

\title{
Sex-based differences in regulatory T cells.
}

Lum Doreen Nebane-Ambe 1975-

University of Louisville

Follow this and additional works at: https://ir.library.louisville.edu/etd

\section{Recommended Citation}

Nebane-Ambe, Lum Doreen 1975-, "Sex-based differences in regulatory T cells." (2005). Electronic Theses and Dissertations. Paper 1045.

https://doi.org/10.18297/etd/1045

This Doctoral Dissertation is brought to you for free and open access by ThinkIR: The University of Louisville's Institutional Repository. It has been accepted for inclusion in Electronic Theses and Dissertations by an authorized administrator of ThinkIR: The University of Louisville's Institutional Repository. This title appears here courtesy of the author, who has retained all other copyrights. For more information, please contact thinkir@louisville.edu. 


\title{
SEX-BASED DIFFERENCES IN REGULATORY T CELLS
}

\author{
By
}

\author{
Lum Doreen Nebane-Ambe
}

\begin{abstract}
A Dissertation
Submitted to the Faculty of the Graduate School of the University of Louisville in partial Fulfillment of the Requirements for the Degree of
\end{abstract}

Doctor of Philosophy

Department of Microbiology and Immunology

University of Louisville

Louisville, Kentucky

December, 2005 


\section{SEX-BASED DIFFERENCES IN REGULATORY T CELLS}

By

Lum Doreen Nebane-Ambe

A Dissertation Approved on

November 18, 2005

by the following Dissertation Committee:

Dissertation Director 


\section{DEDICATION}

This thesis is dedicated to the loving and everlasting memory of our beloved son,

\section{Naithan Abinwi Nebafu Ambe}

$\begin{array}{ll}\text { Sunrise: } & \text { Nov 30, } 2004 \\ \text { Sunset: } & \text { April 10, } 2005\end{array}$

A Brave Little Boy with a Fighting Spirit, Now our Little Angel in Heaven.

Bebe, you Forever Changed our Lives and we Miss you so Much. 


\section{ACKNOWLEDGEMENTS}

It is my first duty to acknowledge with pleasure, my indebtedness to all the individuals, and institutions that have contributed in various ways to the formulation, execution and submission of the work described in this thesis.

I thereby take this opportunity to express immense thanks to my mentor, Dr. Michele M. Kosiewicz, not only for her guidance, encouragement and stimulating discussions, but also for her patience, tolerance, kindness and unfailing cooperation throughout my stay in her laboratory.

My profound gratitude also goes to Dr. Pascale Alard, one of my committee members who gave me a lot of academic/technical advice and moral support throughout my research project.

Much gratitude also goes to my other committee members, Drs. Suttles, Klinge and Bodduluri for first of all accepting to advise me during this project, and subsequently following through with suggestions, corrections and advice, despite their busy schedules. Special appreciation also goes to my lab-mate Jean Manirarora, for the immense academic, research, moral and self-sacrificing support he gave me towards the end of my project. I also appreciate all the support that was given to me by the rest of my lab mates Sherry Clark, Jason Hudkins, Xiaohong Li, Shuang Liang, Michael Meyers, Sarah Parnell and Yuan Zhao. Immense appreciation also goes to Chris Worth and Jeffery Lay who tirelessly helped in sorting cells for me. 
I also express immense thanks to the Department of Microbiology and Immunology, and the Integrated Program in Biomedical Sciences (IPIBS), for giving me this great and rare financial/academic opportunity to further my education.

Above all, I thank the ALMIGHTY GOD for sustaining me, my beloved husband, Roland, my dear parents/siblings, my extended family and in-laws, who all immensely supported me in every possible way throughout the project and the trying times that arose while I worked at it. 


\section{ABSTRACT \\ SEX-BASED DIFFERENCES IN REGULATORY T CELLS \\ Lum Doreen Nebane-Ambe \\ November 18, 2005}

Females have a higher incidence of autoimmune diseases than males for reasons that are currently unknown. $\mathrm{CD} 4^{+} \mathrm{CD} 25^{+}$regulatory $\mathrm{T}$ cells play an important role in the maintenance of immunological homeostasis and self-tolerance by suppressing autoreactive $\mathrm{T}$ cells that could potentially cause autoimmune diseases.

Given that autoimmune diseases are more prevalent in women compared to men, we hypothesized that sex steroids could influence the incidence and/or progression of autoimmune disease through an effect on $\mathrm{CD} 4{ }^{+} \mathrm{CD} 25^{+}$regulatory $\mathrm{T}$ cell number and/or function. The overall objective of this project was then to determine whether sex steroids mediate sex-based differences in $\mathrm{CD} 4^{+} \mathrm{CD} 25^{+}$regulatory $\mathrm{T}$ cell number, function and phenotype, and through this mechanism influence the differential incidence of systemic lupus erythematosus in females and males. To attain our objectives, we 1) assessed the influence of androgens (dihydrotestosterone) on $\mathrm{CD} 4^{+} \mathrm{CD} 25^{+}$regulatory T-cell number, phenotype and function; 2) assessed the influence of estrogens (estradiol) on $\mathrm{CD} 4{ }^{+} \mathrm{CD} 25^{+}$regulatory $\mathrm{T}$ cell number and function; 3) assessed $\mathrm{CD} 4{ }^{+} \mathrm{CD} 25^{+} \mathrm{T}$ cells and the effects of androgens in an animal model of systemic lupus erythematosus (SLE). 
We found that androgens increased the numbers of $\mathrm{CD} 4^{+} \mathrm{CD} 25^{+}$, $\mathrm{CD}^{+} \mathrm{CD} 25^{+} \mathrm{CD}_{103}{ }^{+}$and $\mathrm{CD} 4^{+} \mathrm{CD} 25^{+} \mathrm{CTLA} 4^{+}$cells. Moreover, male $\mathrm{CD}^{+} \mathrm{CD} 25^{+} \mathrm{CD} 103^{+}$cells expressed more of the regulatory cell-associated transcription factor, Foxp3, than females, which also correlated with an enhancement in in vitro regulatory function, because male $\mathrm{CD} 4^{+} \mathrm{CD} 25^{+}$and $\mathrm{CD} 4^{+} \mathrm{CD} 25^{+} \mathrm{CD} 103^{+}$cells suppressed the proliferation of responder $\mathrm{CD} 4^{+} \mathrm{CD} 25^{-}$cells better than those from females. Conversely, estrogens had a very little effect on regulatory T cell numbers, phenotype and function. Our conclusion was that androgens, but not estrogens, can in fact, have an influence on the numbers, function and phenotype of $\mathrm{CD} 4^{+} \mathrm{CD} 25^{+}$regulatory $\mathrm{T}$ cells. In radiation bone marrow chimera experiments, we determined that androgens increase $\mathrm{CD} 4^{+} \mathrm{CD} 25^{+}$regulatory cell numbers through an effect on the thymic epithelium, but influence the development of $\mathrm{CD} 4^{+} \mathrm{CD} 25^{+}$regulatory function through a direct effect on the bone marrow-derived precursor (not mature) cells.

In the second part of our project, we assessed $\mathrm{CD} 4^{+} \mathrm{CD} 25^{+} \mathrm{T}$ cells and the effects of androgens in a murine model of systemic lupus erythematosus (NZB x NZW) in which only females get disease, and found that female NZB x NZW mice had significantly lower levels of $\mathrm{CD} 4^{+} \mathrm{CD} 25^{+}$and $\mathrm{CD} 4^{+} \mathrm{CD} 25^{+} \mathrm{CD} 103^{+} \mathrm{T}$ cells compared with male mice. Furthermore, androgen deprivation (castration) led to a reduction in the percentages of $\mathrm{CD}^{+} \mathrm{CD} 25^{+} \mathrm{CD} 103^{+}$cells in male mice to levels lower than those found in intact male mice, or comparable to levels in intact females. Moreover, male NZB x NZW mice have more potent and greater numbers of $\mathrm{CD} 4^{+} \mathrm{CD} 25^{+} \mathrm{CD} 103^{+}$cells. Androgen deprivation in males led to an increase in disease as indicated by the increase in antibodies to dsDNA and a coincident reduction in $\mathrm{CD} 4{ }^{+} \mathrm{CD} 25^{+}$cell numbers. On the other hand, the 
administration of androgens to females inhibited disease progression, as reflected in significantly lower levels of dsdNA antibodies compared to placebo-treated females, and this decrease correlated with enhanced $\mathrm{CD} 4{ }^{+} \mathrm{CD} 25^{+}$cell number and function.

Taken together, these data strongly suggest that androgens could influence the incidence and/or severity of disease by affecting the numbers and/or function of regulatory T cells. It also suggests that androgens appear to be associated with an increase in the percentage of $\mathrm{CD} 4{ }^{+} \mathrm{CD} 25^{+}$cells that express the important trafficking molecule, $\mathrm{CD} 103$, which may facilitate the ability of male $\mathrm{CD} 4{ }^{+} \mathrm{CD} 25^{+}$regulatory cells to reach sites of inflammation. These androgen-mediated changes appear to correlate with prevention of disease, thus androgens may confer, at least in part, resistance to autoimmune disease in males through an enhansive effect on $\mathrm{CD} 4{ }^{+} \mathrm{CD} 25^{+}$cell numbers and function. 


\section{TABLE OF CONTENTS}

PAGE

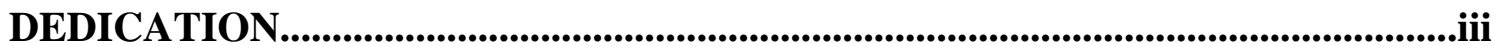

ACKNOWLEDGEMENTS........................................................................................iv

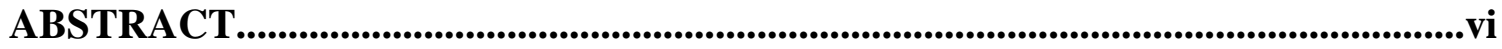

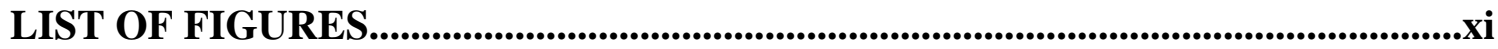

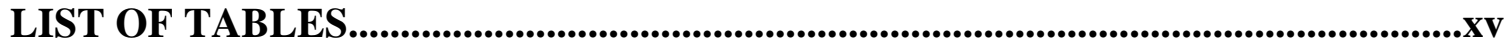

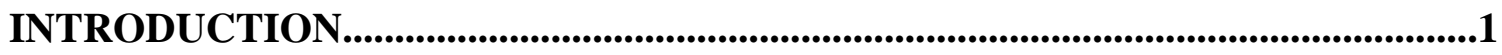

General overview of $\mathrm{CD}^{+} \mathrm{CD}^{+} 5^{+}$regulatory T cells........................

Accessory molecules associated with the regulatory activity of CD4 ${ }^{+} \mathrm{CD} 25^{+} \mathrm{T}$

Cells..................................................................

Foxp3, CD103 and CD62L may identify the most potent subpopulation of

$\mathrm{CD}^{+}{ }^{+} \mathrm{CD} 25^{+}$regulatory $\mathrm{T}$ cells........................................

CD28/B7-1/B7-2/CTLA-4 and regulatory T cells.........................13

Relationship between sex steroids and autoimmune disease...................15

Compartments/targets of the immune system influenced by sex steroids..........21

Possible role of $\mathrm{CD} 4^{+} \mathrm{CD} 25^{+} \mathrm{T}$ cells and steroids in SLE disease progression....23

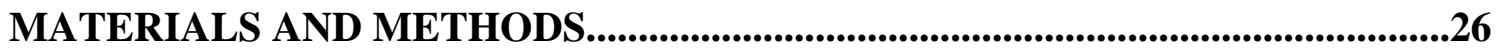


Specific Aim 1.

Assessing the influence of androgen (dihydrotestosterone) on $\mathrm{CD}^{+} \mathrm{CD} 25^{+}$

regulatory $\mathrm{T}$-cell number, phenotype and function......................................35

Analysis of phenotype and function of $\mathrm{CD} 4^{+} \mathrm{CD} 25^{+}$regulatory $\mathrm{T}$ cells from

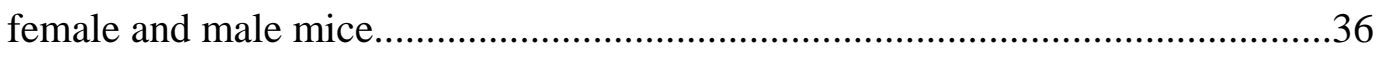

Analysis of phenotype and function of $\mathrm{CD} 4^{+} \mathrm{CD} 25^{+} \mathrm{CD}_{103}{ }^{+}$cells from female and male mice.

Androgens may modulate $\mathrm{CD} 4{ }^{+} \mathrm{CD} 25^{+}$regulatory $\mathrm{T}$ cell numbers, phenotype and

function.

Androgens do not have a direct in vitro effect on $\mathrm{CD} 4^{+} \mathrm{CD} 25^{+} \mathrm{T}$ cell

function.

Androgens influence $\mathrm{CD} 4^{+} \mathrm{CD} 25^{+}$regulatory $\mathrm{T}$ cells through a direct effect on the thymic epithelium.

Specific Aim 2. Assessing the influence of estrogens (estradiol) on

$\mathrm{CD}^{+} \mathrm{CD} 25^{+}$regulatory $\mathrm{T}$ cell number and function.

.97

Estrus cycle has a small influence on the numbers and function of $\mathrm{CD} 4{ }^{+} \mathrm{CD} 25^{+}$

regulatory cells

Estrogens do not have a direct effect on $\mathrm{CD} 4{ }^{+} \mathrm{CD} 25^{+} \mathrm{T}$ cell function in vitro....100

Specific Aim 3. Assessment of $\mathrm{CD}^{+} \mathrm{CD}^{+} 5^{+} \mathrm{T}$ cells and the effects of

androgens in systemic lupus erythematosus.

.106

Analysis of numbers, function and phenotype of $\mathrm{CD} 4{ }^{+} \mathrm{CD} 25^{+}$regulatory $\mathrm{T}$ cells

from female and male NZB x NZW mice

107 
Assess the effects of androgens on $\mathrm{CD}^{+} \mathrm{CD} 25^{+} \mathrm{T}$ cells in NZB x NZW mice and correlate these effects with SLE disease regression or progression

a). Effect of the absence of androgens in male NZB x NZW mice.

b). Effect of androgen treatment of female NZB x NZW mice.

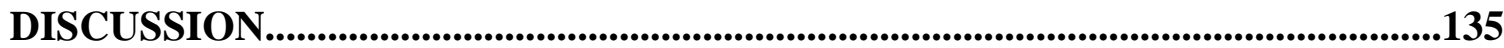

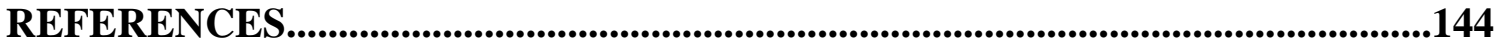

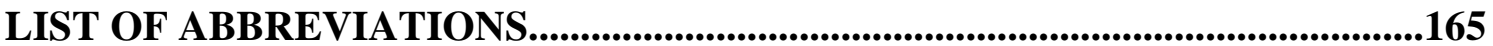

CURRICULUM VITAE.......................................................................................168 


\section{LIST OF FIGURES}

PAGE

\section{FIGURE}

1. Adult C57BL/6 male mice have significantly more $\mathrm{CD} 4^{+} \mathrm{CD} 25^{+}$cells than

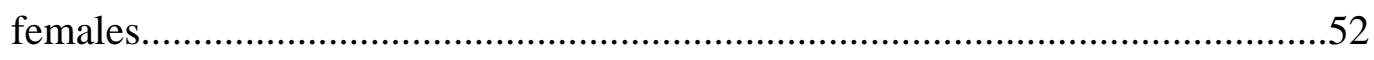

2. Adult SJL male mice have significantly more $\mathrm{CD} 4{ }^{+} \mathrm{CD} 25^{+}$cells than females..

3. No differences in the percentages of $\mathrm{CD} 4^{+} \mathrm{CD} 25^{+}$cells between pre-pubertal female versus male C57BL/6, SJL and Balb/c mice.

.54

4. A \& B. No differences in the percentage of $\mathrm{CD} 4^{+} \mathrm{CD} 25^{+}$cells expressing $\mathrm{CD} 62 \mathrm{~L}$, CTLA-4, GITR or CD45RB between adult female and male C57BL/6 mice......55

C \& D. There are significant differences in the percentage of $\mathrm{CD} 4^{+} \mathrm{CD} 25^{+}$cells expressing CD103 between adult female versus male mice....................................57

5. There is no difference in the levels of CD103 expression by pre-pubertal female and male mice.

6. A \& B. $\mathrm{CD}^{+} \mathrm{CD}^{2} 5^{+} \mathrm{T}$ cells from adult female and male mice do not exhibit significant differences in the mean intensity of expression of CD62L, GITR, CD45RB, or CD103(A), but do exhibit differences in the expression of CTLA-4 (B). 
C \& D. $C D 4^{+} \mathrm{CD} 25^{+} \mathrm{T}$ cells from adult female, intact or castrated or Tfm male mice do not exhibit significant differences in the mean intensity of expression of CD62L, GITR, CD45RB, or CD103 (A), but do exhibit differences in the expression of CTLA-4 (B) ......................................60

7. Standard in vitro assay for regulatory $\mathrm{T}$ cell function (proliferation assay)......61

8. Male $\mathrm{CD} 4^{+} \mathrm{CD} 25^{+}$cells suppress significantly better than female $\mathrm{CD} 4^{+} \mathrm{CD} 25^{+}$

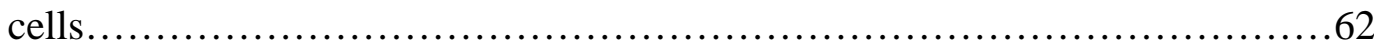

9. Male $\mathrm{CD} 4{ }^{+} \mathrm{CD} 25^{+} \mathrm{CD} 103^{+}$cells suppress significantly better than female $\mathrm{CD} 4^{+} \mathrm{CD} 25^{+}$cells

10. $\mathrm{CD} 4^{+} \mathrm{CD} 25^{+} \mathrm{CD} 103^{+}$, but not $\mathrm{CD} 4^{+} \mathrm{CD} 25^{+}$cells, from males express significantly higher levels of Foxp3 compared with females.

11. Castration in C57BL/6 and SJL males decreases the percentage of $\mathrm{CD} 4^{+} \mathrm{CD} 25^{+}$ $\mathrm{T}$ cells to levels comparable to those found in females

12. Testicular feminization mice (Tfm) have a lower percentage of $\mathrm{CD} 4^{+} \mathrm{CD} 25^{+}$ cells compared with wild-type male mice. .68

13. $\mathrm{CD} 4{ }^{+} \mathrm{CD} 25^{+}$cells from intact wild-type male mice express significantly more CD103, but not CD62L, CTLA-4, GITR or CD45RB compared with wild-type female, or castrated or Tfm male mice.

14. Androgens increase the percentage of $\mathrm{CD} 4^{+} \mathrm{CD} 25^{+}$regulatory $\mathrm{T}$ cells in females. .71

15. Treatment with androgens results in an increase in the percentage of $\mathrm{CD}^{+} \mathrm{CD} 25^{+} \mathrm{CD}_{103}{ }^{+}$regulatory $\mathrm{T}$ cells in females. 
16. Intact $\mathrm{C} 57 \mathrm{BL} / 6$ male $\mathrm{CD} 4^{+} \mathrm{CD} 25^{+} \mathrm{CD} 103^{+}$cells suppress significantly better than intact female, or castrated or $\mathrm{Tfm}$ male $\mathrm{CD} 4^{+} \mathrm{CD} 25^{+} \mathrm{CD} 103^{+}$cells..............73

17. Androgen receptor mRNA is expressed by both $\mathrm{CD} 4^{+} \mathrm{CD} 25^{+}$and $\mathrm{CD} 4^{+} \mathrm{CD} 25^{-}$ T cells.

18. Treatment of $\mathrm{CD} 4{ }^{+} \mathrm{CD} 25^{+}$cells with androgens in vitro does not affect their regulatory function

19. Pretreatment of $\mathrm{CD} 4^{+} \mathrm{CD} 25^{+}$with androgens has no direct effect on regulatory function of $\mathrm{CD} 4^{+} \mathrm{CD} 25^{+}$cells.

20. Protocol to test for the influence of androgens on numbers, phenotype and/or function of $\mathrm{CD} 4{ }^{+} \mathrm{CD} 25^{+}$cells through an effect on bone-marrow derived cells...77

21. Androgens influence the function but not the percentage of $\mathrm{CD} 4^{+} \mathrm{CD} 25^{+}$cells through an effect on bone marrow-derived cells.

22. Protocol to test for the influence of androgens on the numbers and phenotype of $\mathrm{CD} 4^{+} \mathrm{CD} 25^{+}$cells through an effect on the non-bone marrow-derived compartment

23. Androgens influence the percentages of $\mathrm{CD} 4^{+} \mathrm{CD} 25^{+}$and $\mathrm{CD} 4{ }^{+} \mathrm{CD} 25^{+} \mathrm{CD} 103^{+}$ cells through an effect on the non-bone marrow-derived compartment.

24. Protocol to test for the influence of androgens on the numbers and phenotype of $\mathrm{CD} 4^{+} \mathrm{CD} 25^{+}$cells through an effect on the thymus

25. Androgens influence the percentages of $\mathrm{CD} 4^{+} \mathrm{CD} 25^{+}$and $\mathrm{CD} 4^{+} \mathrm{CD} 25^{+} \mathrm{CD} 103^{+}$ cells through an effect on the thymus 
26. Diestrus, estrus and proestrus stages of the estrous cycle as observed under the microscope and reflect changes in estrogen levels that occur during each

stage. .101

27. The percentages of $\mathrm{CD} 4^{+} \mathrm{CD} 25^{+}$and $\mathrm{CD} 4^{+} \mathrm{CD} 25^{+} \mathrm{CD} 103^{+}$regulatory $\mathrm{T}$ cells are not significantly different between the diestrus, proestrus and estrus stages....102

28. $\mathrm{CD} 4^{+} \mathrm{CD} 25^{+}$regulatory $\mathrm{T}$ cells in proestrus are slightly less effective than those from male mice at regulating proliferation of responder cells. 103

29. There were no significant differences in Foxp3 expression by $\mathrm{CD} 4^{+} \mathrm{CD} 25^{+} \mathrm{T}$ cells from diestrus, estrus or proestrus females or males .104

30. Estradiol does not have a direct effect on $\mathrm{CD} 4^{+} \mathrm{CD} 25^{+} \mathrm{T}$ cells in vitro 105

31. NZB x NZW female mice have significantly fewer $\mathrm{CD} 4^{+} \mathrm{CD} 25^{+}$cells than males at 9,16 and 18 , but not 28 weeks of age

32. Blood $\mathrm{CD} 4{ }^{+} \mathrm{CD} 25^{+}$cells from female mice express significantly lower CD103 compared with male mice.

33. Males have significantly more $\mathrm{CD} 4^{+} \mathrm{CD} 25^{+} \mathrm{CD} 103^{+}$cells at 9 and 16 , but not 28 weeks of age, while females have fewer $\mathrm{CD} 4^{+} \mathrm{CD} 25^{+} \mathrm{CD} 62 \mathrm{~L}^{\text {hi }}$ cells than males at 28 weeks of age

34. Male NZB x NZW $\mathrm{CD} 4^{+} \mathrm{CD} 25^{+} \mathrm{CD}_{103^{+}}$but not $\mathrm{CD} 4^{+} \mathrm{CD} 25^{+}$cells suppress $\mathrm{CD} 4^{+} \mathrm{CD} 25^{-}$cells significantly better than female $\mathrm{CD} 4^{+} \mathrm{CD} 25^{+} \mathrm{CD} 103^{+}$cells...119

35. $\mathrm{CD} 4^{+} \mathrm{CD} 25^{+} \mathrm{CD} 103^{+}$cells from androgen pellet-treated female but not those from intact male mice, suppressed $\mathrm{CD} 4^{+} \mathrm{CD} 25^{-}$cells significantly better than $\mathrm{CD}^{+} \mathrm{CD} 25^{+} \mathrm{CD} 103^{+}$cells from female vehicle-pellet treated or castrated male mice, respectively. 
36. The absence of androgens could lead to a reduction in the percentages of $\mathrm{CD}^{+} \mathrm{CD}^{+} 5^{+}$and $\mathrm{CD} 4{ }^{+} \mathrm{CD} 25^{+} \mathrm{CD}_{103^{+}}$cells in male mice......................122

37. Castrated male mice have higher levels of serum antibodies to dsDNA than intact male controls that are comparable to those found in females.............123

38. Androgen-treated female mice have levels of serum antibodies to dsDNA that are comparable to intact male mice, but are significantly lower than in placebo-treated female controls.............................................124 


\section{LIST OF TABLES}

PAGE

\section{TABLE}

1. Female/Male Ratios in Autoimmune Diseases..........................................................84

2. Analysis of the percentage of $\mathrm{CD} 4^{+} \mathrm{CD} 25^{+} \mathrm{T}$ cells in female and male mice.........85

3. Analysis of the percentage of $\mathrm{CD} 4^{+} \mathrm{CD} 25^{+} \mathrm{CD} 103^{+} \mathrm{T}$ cells in female and male mice.

4. a. Mean intensity of expression of CD103, CD45RB, CTLA-4, GITR, and CD62L

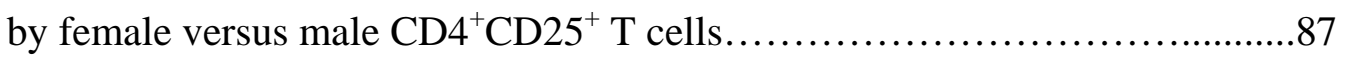

b. Mean intensity of expression of CD103, CD45RB, CTLA-4, GITR, and CD62L by intact male versus female, castrated or Tfm male $\mathrm{CD} 4^{+} \mathrm{CD} 25^{+} \mathrm{T}$ cells.......88

5. a. Absolute numbers of $\mathrm{CD} 4^{+} \mathrm{CD} 25^{+} \mathrm{T}$ or $\mathrm{CD} 4^{+} \mathrm{CD} 25^{+} \mathrm{CD} 2103^{+}$cells in female and male mice. .89

b. Absolute numbers of $\mathrm{CD} 4{ }^{+} \mathrm{CD} 25^{+} \mathrm{CD} 2103^{+} \mathrm{T}$ cells in female and male mice..89

6. a. Comparison of $\mathrm{CD} 4{ }^{+} \mathrm{CD} 25^{+} \mathrm{T}$ cell regulatory function between adult female and male C57BL/6 mice.............................................90

b. Comparison of $\mathrm{CD} 4^{+} \mathrm{CD} 25^{+} \mathrm{CD}_{103^{+}} \mathrm{T}$ cell regulatory function between female and male SJL mice. 
7. a. Comparison of $\mathrm{CD} 4^{+} \mathrm{CD} 25^{+} \mathrm{CD} 103^{+} \mathrm{T}$ cell regulatory function between female and male C57BL/6 mice.........................................92

b. Comparison of $\mathrm{CD} 4^{+} \mathrm{CD} 25^{+} \mathrm{CD}_{103^{+}} \mathrm{T}$ cell regulatory function between female and male SJL mice..............................................93

8. a. Analysis of the percentage of $\mathrm{CD} 4{ }^{+} \mathrm{CD} 25^{+} \mathrm{T}$ cells in castrated mice.............94

b. Analysis of the percentage of $\mathrm{CD} 4{ }^{+} \mathrm{CD} 25^{+} \mathrm{T}$ cells in $\mathrm{Tfm}$ male mice............94

c. Analysis of the percentage of $\mathrm{CD}^{+} \mathrm{CD}_{2} 5^{+} \mathrm{T}$ cells in androgen pellet-treated

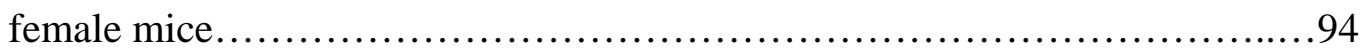

9. Percentage of $\mathrm{CD} 4^{+} \mathrm{CD} 25^{+} \mathrm{CD} 103^{+} \mathrm{T}$ cells in intact female or intact or castrated or Tfm male and androgen pellet-treated female..............................95

10. Comparison of suppression by regulatory $\mathrm{CD} 4^{+} \mathrm{CD} 25^{+} \mathrm{CD} 103^{+} \mathrm{T}$ cells from intact female or intact or castrated or Tfm male mice.......................96

11. a. Analysis of the percentage of lymph node $\mathrm{CD} 4^{+} \mathrm{CD} 25^{+} \mathrm{T}$ cells in female and male NZB x NZW mice.

b. Time course analysis of the percentage of blood $\mathrm{CD} 4{ }^{+} \mathrm{CD} 25^{+} \mathrm{T}$ cells in female

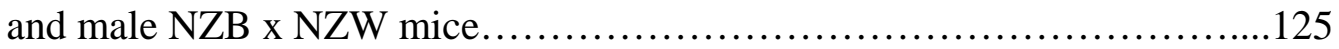

12. a. Analysis of the percentage of lymph node $\mathrm{CD} 4^{+} \mathrm{CD} 25^{+} \mathrm{CD} 103^{+} \mathrm{T}$ cells in female and male NZB x NZW mice. 126

b. Time course analysis of the percentage of blood $\mathrm{CD} 4^{+} \mathrm{CD} 25^{+} \mathrm{CD}_{103^{+}} \mathrm{T}$ cells in female and male NZB x NZW mice.....................................126

13. a. Analysis of the percentage of CD62L, CTLA-4 and Foxp3 by lymph node $\mathrm{CD} 4^{+} \mathrm{CD} 25^{+} \mathrm{T}$ cells in female and male NZB x NZW mice. 
14. Analysis of the percentage of thymus $\mathrm{CD} 4{ }^{+} \mathrm{CD} 25^{+}$or $\mathrm{CD} 25^{+} \mathrm{CD} 103^{+}$regulatory $\mathrm{T}$ cells in female and male NZB x NZW mice. . 128

15. a. Analysis of the absolute numbers of lymph node $\mathrm{CD} 4{ }^{+} \mathrm{CD} 25^{+} \mathrm{T}$ cells in female and male NZB x NZW mice.

b. Analysis of the absolute numbers of lymph node $\mathrm{CD} 4^{+} \mathrm{CD} 25^{+} \mathrm{CD} 103^{+} \mathrm{T}$ cells in female and male NZB x NZW mice. 129

16. a. Comparison of $\mathrm{CD} 4^{+} \mathrm{CD} 25^{+} \mathrm{T}$ cell regulatory function between female and male NZB x NZW mice.

b. Comparison of $\mathrm{CD} 4^{+} \mathrm{CD} 25^{+} \mathrm{CD} 103^{+} \mathrm{T}$ cell regulatory function between female and male NZB x NZW mice.

17. a. Time course analysis of the percentage of blood $\mathrm{CD} 4^{+} \mathrm{CD} 25^{+} \mathrm{T}$ cells in androgen-treated female NZB x NZW mice...

b. Time course analysis of the percentage of blood $\mathrm{CD} 4^{+} \mathrm{CD} 25^{+} \mathrm{CD} 103^{+}$

T cells in androgen-treated female NZB x NZW mice.

18. Comparison of $\mathrm{CD}_{2} 5^{+} \mathrm{CD} 103^{+} \mathrm{T}$ cell regulatory function between 6 month old female and male NZB x NZW mice. ...

19. Analysis of the percentage of $\mathrm{CD} 4^{+} \mathrm{CD} 25^{+}$and $\mathrm{CD} 4^{+} \mathrm{CD} 25^{+} \mathrm{CD} 103^{+} \mathrm{T}$ cells in lymph nodes in castrated and androgen-treated female and male NZB x NZW mice.

20. Analysis of the absolute numbers of lymph node $\mathrm{CD} 4^{+} \mathrm{CD} 25^{+}$and $\mathrm{CD}^{+} \mathrm{CD} 25^{+} \mathrm{CD}_{103}{ }^{+} \mathrm{T}$ cells in lymph nodes in castrated and androgen treated female and male NZB x NZW mice. 


\section{INTRODUCTION}

\section{General overview of $\mathrm{CD}^{+}{ }^{+} \mathrm{CD} 25^{+}$regulatory $\mathrm{T}$ cells.}

In 1969, Nishizuka and Sakakura discovered that neonataly thymectomized mice developed autoimmune oophoritis that resulted in infertility (1). However, subsequent studies showed that the phenomenon could be prevented by transferring thymocytes or splenocytes from mice of any age or splenocytes of adult mice (2). Sakaguchi and others later showed that there was a subpopulation of $\mathrm{CD}^{+} \mathrm{T}$ cells which could prevent the induction of autoimmune diseases, that were subsequently designated regulatory $\mathrm{T}$ cells (3). They observed that the adoptive transfer of $\mathrm{CD} 4^{+} \mathrm{CD} 25^{+}$-depleted $\mathrm{T}$ cells induced several organ-specific autoimmune diseases in immunodeficient recipient mice. On the other hand, the adoptive transfer of $\mathrm{CD} 4^{+} \mathrm{CD} 25^{+} \mathrm{T}$ cells prevented the development of organ-specific autoimmunity in some strains of mice that were thymectomized on day 3

of life. The above studies provide powerful evidence that $\mathrm{CD} 4{ }^{+} \mathrm{CD} 25^{+}$regulatory cells are critical for generating and establishing peripheral self-tolerance (4).

A growing body of evidence in recent years has shown that $\mathrm{CD} 4^{+} \mathrm{CD} 25^{+}$ regulatory cells play an active role in maintaining immunological self tolerance (immunological unresponsiveness to self antigens) and the regulation of other immune responses to non-self antigens (5-7). The normal process of $\mathrm{T}$ cell maturation in the thymus generates a naturally-occurring subset of $\mathrm{CD} 4^{+} \mathrm{CD} 25^{+}$Treg (nTreg) cells that 
develop and acquire their suppressive phenotype in the thymus, and subsequently migrate to the periphery where they establish and exhibit a stable function that may potentially prevent autoimmune diseases $(3,8-11)$. Eventually, $\mathrm{CD} 4{ }^{+} \mathrm{CD} 25^{+}$regulatory $\mathrm{T}$ cell expansion in the periphery, is promoted by the self-antigens that mediated their selection in the thymus (11), which finally generates $5-10 \%$ of peripheral $\mathrm{CD} 4^{+} \mathrm{T}$ cells in normal naïve mice $(3,8)$ and healthy humans $(12-14)$. Nevertheless, without requiring the thymus, normal $\mathrm{CD} 4^{+} \mathrm{CD} 25^{-}$possess an inherent ability to spontaneously convert in the periphery into $\mathrm{CD} 4^{+} \mathrm{CD} 25^{+}$regulatory $\mathrm{T}$ cells that are physically and functionally indistinguishable from naturally occurring $\mathrm{CD} 4{ }^{+} \mathrm{CD} 25^{+}$regulatory $\mathrm{T}$ cells (15-17).

Naturally occurring regulatory $\mathrm{T}$ cells have been shown to inhibit inappropriate activation of cell- and antibody-mediated immune responses against self antigen (18) as well as innate immune responses (19). They have also been shown to prevent the development of autoimmune disease in animal models and also play an important role in transplantation tolerance and the prevention of graft rejection (20). $\mathrm{CD} 4^{+} \mathrm{CD} 25^{+}$ regulatory $\mathrm{T}$ cells express $\mathrm{CD} 25$, the high-affinity receptor for $\operatorname{IL}-2(3,21)$ and studies have shown that IL-2 is required for the production of $\mathrm{CD} 4{ }^{+} \mathrm{CD} 25^{+}$nTreg cells during thymic development (22). Others have shown that IL-2 signaling is required for $\mathrm{CD} 4{ }^{+}$ regulatory $\mathrm{T}$ cell function (23). Although the identification of $\mathrm{CD} 4{ }^{+} \mathrm{CD} 25^{+}$regulatory $\mathrm{T}$ cells is associated with expression of $\mathrm{CD} 25$, this receptor is also expressed on normal activated $\mathrm{T}$ cells. Thus, $\mathrm{CD} 25$ is an activation marker for T cells, and activated effector T cells also express $\mathrm{CD} 25^{+}$, suggesting that not all $\mathrm{CD} 25^{+}$cells are regulatory cells (24). $\mathrm{CD}^{+} \mathrm{CD} 25^{+} \mathrm{T}$ cells can inhibit in vitro $\mathrm{T}$ cell proliferation that is induced by anti-CD3 (25). $\mathrm{CD} 4{ }^{+} \mathrm{CD} 25^{+} \mathrm{T}$ cells are anergic to TCR stimulation in vitro, and do not proliferate 
or produce IL-2 in response to T cell stimuli such as concanavalin A or anti-CD3. However, they require activation via the TCR to exert their regulatory/suppressive functions (26-28). Once activated, $\mathrm{CD} 4^{+} \mathrm{CD} 25^{+}$regulatory $\mathrm{T}$ cells suppress both $\mathrm{CD} 4^{+}$ and $\mathrm{CD}^{+} \mathrm{T}$ cell responses in an antigen non-specific manner (4). Although $\mathrm{CD} 4^{+} \mathrm{CD} 25^{+}$ Treg cells cannot proliferate in vitro, they are capable of proliferating in vivo in response to stimulating antigens (29). A remarkable feature of these regulatory cells is that they are highly sensitive to antigenic stimulation. They require a much lower concentration of antigen for stimulation to exert suppressive activity, compared with the antigen concentration required for the activation/proliferation of naïve $\mathrm{CD} 4^{+} \mathrm{CD} 25^{-} \mathrm{T}$ cells with the same antigen specificity (28).

\section{Accessory molecules associated with the regulatory activity of $\mathrm{CD4}{ }^{+} \mathrm{CD} 25^{+} \mathrm{T}$ cells.}

Recent studies indicate that CD25 is not the most specific cell surface marker for the $\mathrm{CD} 4{ }^{+} \mathrm{CD} 25^{+}$naturally-occurring Treg cells because it is also an activation marker for other $\mathrm{T}$ cells; for example $\mathrm{CD} 4^{+} \mathrm{CD} 25^{-} \mathrm{T}$ cells can also upregulate expression of $\mathrm{CD} 25$ after TCR activation. Since CD25 is not a specific marker for naturally produced regulatory $\mathrm{T}$ cells, other surface markers specific to regulatory cells have been sought. Apart from the CD25 receptor, naturally-occurring T regulatory cells also constitutively express various cell surface/intracellular molecules associated with activated/memory cells, including; CD45RB, cytotoxic T lymphocyte antigen-4 (CTLA-4), glucocorticoidinduced tumor necrosis factor receptor-related gene (GITR), CD134 (OX-40), CD38, TGF- $\beta$, Foxp3, CD103 ( $\alpha_{E} \beta_{7}$ intergrin), and CD62L $(3,30-35)$. Most of these markers have been shown to segregate with suppressive function (35-39). GITR, CTLA-4, 
CD134 (OX-40) and CD103 were reportedly highly expressed on $\mathrm{CD}^{+} \mathrm{CD} 25^{+}$regulatory $\mathrm{T}$ cells, but not at all or to a lesser extent on naïve $\mathrm{CD} 4^{+} \mathrm{CD} 25^{-} \mathrm{T}$ cells (35). Although $\mathrm{CD} 4^{+} \mathrm{CD} 25^{+} \mathrm{T}$ cells are the only $\mathrm{CD} 4^{+} \mathrm{T}$ cells to constitutively express $\mathrm{CD} 25$ as well as CTLA-4 and GITR in the non-activated state (14), no phenotypic surface markers are currently available to readily distinguish activated effector cells from naturally-occurring $\mathrm{CD} 4{ }^{+} \mathrm{CD} 25^{+}$Tregs (4). Nevertheless, the above markers and others to be discussed are essential for inducing, propagating or maintaining the regulatory (suppressive) activity of $\mathrm{CD} 4^{+} \mathrm{CD} 25^{+}$regulatory cells.

$\mathrm{CD} 4{ }^{+} \mathrm{CD} 25^{+}$regulatory $\mathrm{T}$ cells constitutively express CTLA-4, a costimulatory molecule that may be needed for their survival and/or suppressive activity when ligated $(32,33)$. CTLA-4 is a homologue of $\mathrm{CD} 28$ and a positive costimulator of $\mathrm{CD} 4^{+} \mathrm{CD} 25^{+}$ regulatory T cell activity. However, CD28 has higher T cell surface expression levels than CTLA-4, but lower affinity for ligands B7.1 and B7.2 (40-44). On the other hand, CTLA-4 has high affinity for its ligands B7.1 and B7.2 on APCs and is a negative costimulator of $\mathrm{T}$ cell activation/function $(45,46)$. Treg cells express CTLA-4 which is perhaps the most well documented signaling molecule involved in the suppression of an immune response. The proposed mechanisms of suppression mediated by Treg cells, which ranges from direct cell-cell contact to the release of regulatory cytokines (47-49), includes CTLA-4 as a potent costimulatory molecule involved in Treg-mediated suppression of effector T cells. Cell-to-cell contact demonstrated by ligation of CD80 and CD86 on effector T cells by CTLA-4 on suppressor cells resulted in the suppression of the effector $\mathrm{T}$ cells, implying contact between suppressors and effectors is needed for in vitro suppression $(50,51)$. To emphasize the importance of CTLA-4 in Treg-mediated 
suppression, other researchers have shown that coating allogeneic cells with anti-CTLA-4 $\mathrm{Ab}$ cells engages CTLA-4 and induces immune tolerance to these cells through selective induction of an Ag-specific $\mathrm{CD} 4{ }^{+} \mathrm{CD} 25^{+} \mathrm{CTLA}-4^{\text {hi }}$ regulatory T cell (Treg cell) population (52). When the CTLA-4 on these activated allogeneic cells is engaged in this manner, the cells induce immune hyporesponsiveness through up-regulation of the regulatory cytokines IL-10, TGF- $\beta 1$, and IL-4 and suppression of proinflammatory cytokines IFN- $\gamma$ and IL-2.

Treg cells also differentially express CD45RB, which in mice, is best delineated by high and low expression of CD45 exon B-containing isoforms, respectively designated $\mathrm{CD}_{45 \mathrm{RB}} \mathrm{hi}^{\mathrm{hi}}$ and $\mathrm{CD} 45 \mathrm{RB}^{\text {lo }}(53,54)$. Naïve $\mathrm{CD} 4^{+} \mathrm{T}$ cells from normal mice generally express high levels of CD45RB (CD45RB $\left.{ }^{\text {hi }}\right)$ but when they encounter antigen, they down-regulate the expression to lower levels of CD45RB $\left(C D 45 R B^{\text {lo }}\right)$. Transfer of $\mathrm{CD} 4^{+} \mathrm{CD} 45 \mathrm{RB}^{\text {hi }}$ cells into immunocompromised mice induces colitis which is prevented by co-transfer of $\mathrm{CD}^{+} \mathrm{CD}^{+} 5 \mathrm{RB}^{\text {lo }}$ cells, suggesting that this population contains a potent subset of regulatory cells which may include the $\mathrm{CD} 4^{+} \mathrm{CD} 25^{+}$cells (55).

GITR is a member of the TNFR superfamily. It is another surface marker that is not exclusively expressed by $\mathrm{CD} 4{ }^{+} \mathrm{CD} 25^{+}$regulatory $\mathrm{T}$ cells, for it is constitutively present on a very small population of $\mathrm{CD} 4^{+} \mathrm{CD} 25^{-}$non-activated $\mathrm{T}$ cells $(34,35,56)$ and is also upregulated by activated T cells $(9,57)$. Studies have shown that GITR is a costimulatory molecule for mouse $\mathrm{T}$ cell subpopulations $(58,59)$. Although analysis by both microarray and $\mathrm{FACS}^{\circledR}$ have shown that non-activated $\mathrm{CD} 4{ }^{+} \mathrm{CD} 25^{+}$regulatory $\mathrm{T}$ cells constitutively and abundantly express GITR, up-regulation of GITR also occurs following activation of CD25 $\mathrm{T}$ cells $(34,35)$. The high-level, basal expression of GITR 
by $\mathrm{CD} 4{ }^{+} \mathrm{CD} 25^{+}$regulatory $\mathrm{T}$ cells suggested an important and regulatory role for GITR on this subset, which was further supported by functional studies in which the addition of agonistic anti-GITR Abs to cocultures of suppressor and responder $\mathrm{T}$ cells led to a reversal of suppressive activity by $\mathrm{CD} 4^{+} \mathrm{CD} 25^{+}(34,35)$. However, using combinations of $\mathrm{CD} 4^{+} \mathrm{CD} 25^{+}$and $\mathrm{CD} 4^{+} \mathrm{CD} 25^{-} \mathrm{T}$ cells from wild-type and $\mathrm{GITR}^{-1-}$ mice in coculture experiments, Stephens et al later found that ligation of GITR on the CD25- responder T cells, not the $\mathrm{CD} 25^{+}$suppressor $\mathrm{T}$ cells, was required to abrogate suppression (60). In the absence of $\mathrm{CD} 4{ }^{+} \mathrm{CD} 25^{+} \mathrm{T}$ cells, $\mathrm{GITR}^{-/} \mathrm{T}$ cells mounted proliferative responses similar to those of wild-type animals. They suggested that GITR/GITR-L engagement provides an undefined signal that renders effector $\mathrm{T}$ cells resistant to the inhibitory effects of $\mathrm{CD} 4^{+} \mathrm{CD} 25^{+} \mathrm{T}$ cells.

$\mathrm{CD} 4{ }^{+} \mathrm{CD} 25^{+}$regulatory $\mathrm{T}$ cells also produce high levels of TGF- $\beta$ in vitro $(21,61$, 62). Although the function of TGF- $\beta$ in suppression of $T$ cell proliferation is controversial, some in vitro studies have shown that anti-TGF- $\beta$ abolishes suppression by $\mathrm{CD}^{+} \mathrm{CD} 25^{+}(62)$. This concept, however, is controversial since both cell contact and cytokine-based mechanisms have been proposed; for instance, roles for soluble interleukin-10 and transforming growth factor-beta (TGF- $\beta$ ) have been suggested (44, 63-67). However, other in vitro studies show that $\mathrm{CD} 4^{+} \mathrm{CD} 25^{+}$regulatory $\mathrm{T}$ cells require cell-to-cell contact-dependent, surface-bound TGF- $\beta$, but not a cytokine-dependent (soluble factor), to mediate their suppressive activity $(27,62,68)$. Moreover, $\mathrm{CD} 4^{+} \mathrm{CD} 25^{+}$regulatory $\mathrm{T}$ cells, but not $\mathrm{CD} 4^{+} \mathrm{CD} 25^{-} \mathrm{T}$ cells, express cell-surface TGF- $\beta$. This suggests that cell-mediated immunosuppression may be mediated by cell surface presentation of TGF- $\beta$ to TGF- $\beta$ R on target cells (62); for instance, the suppression of 
$\mathrm{CD} 8^{+} \mathrm{T}$ cells that mediate autoimmunity (69) or tumor rejection (51) by $\mathrm{CD} 4^{+} \mathrm{CD} 25^{+} \mathrm{T}$ cells requires an intact TGF- $\beta$ receptor II on the $\mathrm{CD} 8^{+} \mathrm{T}$ cells. Studies using a model of $\mathrm{CD} 8^{+} \mathrm{T}$ cell-mediated autoimmune diabetes have shown that $\mathrm{CD} 4^{+} \mathrm{CD} 25^{+} \mathrm{T}$ cells can suppress disease caused by wild-type effector $\mathrm{T}$ cells but do not inhibit $\mathrm{T}$ cells that express a dominant negative TGF- $\beta$ receptor (69).

TGF- $\beta$ may not only be involved in suppression of $\mathrm{CD} 8^{+}$effector $\mathrm{T}$ cells but also may contribute to generation and/or proliferation of $\mathrm{CD} 4{ }^{+} \mathrm{CD} 25^{+}$suppressor cells, as mice defective in TGF- $\beta$ receptor II have reduced numbers of such cells (70). Nevertheless, although the involvement of TGF- $\beta$ in in vitro assays remains controversial, reports have shown that TGF- $\beta$ is required for regulatory cell function in vivo, based on the results that anti-TGF- $\beta$ administration abrogates regulatory cell protection from colitis (33). Moreover, TGF- $\beta$ is also essential in the prevention of autoimmune thyroiditis in rats (71). Others have shown that TGF- $\beta$ is a cytokine, mediating generalized control of autoimmunity $(65,71-75)$ and oral tolerance (76). TGF- $\beta$ treatment of CD $4^{+} \mathrm{CD} 25^{-}$cells may also lead to the induction of the transcription factor FoxP3 in naïve cells $\mathrm{CD} 4^{+} \mathrm{CD} 25^{-}$ $(44,77)$. Since FoxP3 is crucial for development of regulatory activity $(78)$, these data imply that TGF- $\beta$ may play an important role in the development and maintenance of $\mathrm{CD} 4{ }^{+} \mathrm{CD} 25^{+}$regulatory $\mathrm{T}$ cells in vivo. Others have demonstrated that the systemic expression of TGF- $\beta$ in overtly diabetic NOD mice blocks islet destruction, facilitates regeneration of endogenous cell function, and cures overt diabetes (79). They demonstrated that such a protective effect is related to the local emergence of $\mathrm{CD} 4^{+} \mathrm{CD} 25^{+}$Foxp $^{+}$T cells. Overall, TGF- $\beta$ appears to have a variety of functions in the immune system that generally favor immunosuppression, although the exact mechanism 
by which TGF- $\beta$ mediates immunosuppression remains to be fully elucidated. TGF- $\beta$ may be involved in $\mathrm{CD} 4^{+} \mathrm{CD} 25^{+}$regulatory function.

\section{Foxp3, CD103 and CD62L may identify the most potent subpopulation of $\mathrm{CD}^{+} \mathrm{CD}^{+}{ }^{+}$regulatory $\mathrm{T}$ cells.}

Foxp3 (forkhead box P3) is a regulatory gene which encodes a forkhead/winged helix transcription factor, scurfin and may act as a transcriptional repressor (63). Disruption of scurfin (Foxp3), results in the fatal lymphoproliferative disorder that characterizes the scurfy mouse. Foxp3 is exclusively expressed by $\mathrm{CD} 4{ }^{+} \mathrm{CD} 25^{+} \mathrm{T}$ cells in mice and humans, and correlates with the suppressive activity of these cells. $\mathrm{CD} 4^{+} \mathrm{CD} 25^{+} \mathrm{T}$ cells account for almost all of the Foxp3 expression within lymphoid cells (78, 80-84). Studies have shown that 3-day-old mice already contain a significant compartment of Foxp3-expressing $\mathrm{CD} 4{ }^{+} \mathrm{CD} 25^{+}$splenocytes (85). Foxp3 is not only specifically and exclusively expressed in regulatory $\mathrm{T}$ cells, but is also absolutely required for the generation, thymic development and function of the regulatory $\mathrm{T}$ cells $(78,81,82)$. Foxp3 is expressed by $\mathrm{CD} 4^{+} \mathrm{CD} 25^{+} \mathrm{T}$ cells in the thymus and periphery of normal mice and humans (63) and is a specific marker for regulatory activity (78). It is currently the most definitive marker of regulatory function (80-82). Recent studies by Fontenot et al have shown that Foxp3 acts as the regulatory $\mathrm{T}$ cell lineage specification factor and mediator of the genetic mechanism of dominant tolerance (83). They show that the expression of Foxp3 is highly restricted to the subset of $\alpha \beta$ of T cells and strongly correlates with CD25 expression and suppressor activity. Mutations in Foxp3 lead to the depletion of $\mathrm{CD} 4^{+} \mathrm{CD} 25^{+}$regulatory $(81,82)$. Scurfin-deficient (sf) mice lack 
Treg cells and suffer autoimmunity (82) and conversely, transgenic mice that overexpress Foxp3 have increased numbers of Treg cells and display increased immunosuppressive activity when compared to wild-type mice $(81,82)$. Normal nonregulatory $\mathrm{CD} 4^{+} \mathrm{CD} 25^{-} \mathrm{T}$ cells adopted a functional phenotype similar to $\mathrm{CD} 4^{+} \mathrm{CD} 25^{+}$ Treg cells by induced Foxp3-overexpression, and were capable of suppressing pathology in a mouse model of colitis $(81,82)$. Mice with the X-linked scurfy mutation develop a lymphoproliferative disease, whereas the human beings with a similar mutation develop IPEX (immune dysregulation, polyendocrinopathy, enteropathy, X-linked syndrome), which is characterized by the development of an array of autoimmune diseases similar to those found in mice deficient for $\mathrm{CD} 4^{+} \mathrm{CD} 25^{+} \mathrm{T}$ cells (80). The mutation common to both of these diseases is in the Foxp3 gene (86). Collectively, these studies strongly suggest that Foxp3 plays a central role in the generation of $\mathrm{CD} 4{ }^{+} \mathrm{CD} 25^{+}$Treg cells, and illustrate the importance of $\mathrm{CD} 4^{+} \mathrm{CD} 25^{+}$regulatory T cells in the maintenance of homeostasis and prevention of autoimmune and inflammatory diseases in mice and humans. In summary, these findings indicate that Foxp3 may be a master gene that controls the development and function of $\mathrm{CD} 4^{+} \mathrm{CD} 25^{+}$regulatory $\mathrm{T}$ cells and is currently the only known specific marker for $\mathrm{CD} 4^{+} \mathrm{CD} 25^{+}$regulatory $\mathrm{T}$ cells.

$\mathrm{CD} 103\left(\alpha_{\mathrm{E}} \beta_{7}\right.$ intergrin) which recognizes epithelial cadherin (E-cadherin) is a critical component for the intraepithelial homing of $\mathrm{T}$ cells. Most $\mathrm{CD} 8^{+} \mathrm{T}$ cells in or adjacent to the intestinal epithelium and $40-50 \%$ of the $\mathrm{CD} 4^{+} \mathrm{T}$ cells in the intestinal lamina propria express CD103 which mediates binding to E-cadherin at the basolateral side of the epithelium (87-89). CD103 is also expressed by lymphocytes within the bronchial epithelium, by some alveolar wall lymphocytes, and by bronchoalveolar fluid $\mathrm{T}$ 
cells $(90,91)$. Therefore, in general, the $\alpha_{E} \beta_{7}$ intergrin is expressed at high levels in $\mathrm{T}$ cells that seed mucosal tissues $(88,92,93)$. Expression of the $\alpha_{\mathrm{E}} \beta_{7}$ intergrin $(\mathrm{CD} 103)$ delineates murine $\mathrm{CD} 4^{+} \mathrm{CD} 25^{+}$subsets, which differ in their suppressive and functional abilities (31). CD103 identifies the most potent subpopulation of regulatory $\mathrm{CD}_{2} 5^{+} \mathrm{T}$ cells (31), and thus can be regarded as a novel marker for subsets of highly potent, functionally distinct regulatory $\mathrm{T}$ cells specialized for crosstalk with epithelial environments (31). It is expressed by subsets of highly active $\mathrm{CD} 4{ }^{+} \mathrm{CD} 25^{+}$cells (Ding et al, 2003) in naïve mice $(31,35,56,94)$ with $\mathrm{CD} 4^{+} \mathrm{CD} 25^{+} \mathrm{CD} 103^{+}$being more potent both in vitro and in vivo. In other studies, $\mathrm{CD} 103^{+} \mathrm{CD} 25^{+}$cells are more suppressive in vitro and are more effective at inhibiting inflammatory disease than $\mathrm{CD} 4{ }^{+} \mathrm{CD} 25^{+} \mathrm{CD} 103^{-}$cells (95). It is therefore tempting to suggest that $\mathrm{CD} 103^{+}$expressing subsets, by combining high suppressive potential with specific migration behavior into inflamed sites, could have a strong therapeutic potential in established autoimmune diseases. To support these data, Belkaid et al have shown that the expression of $\alpha_{E} \beta_{7}$ intergrin is necessary for the homing of regulatory $\mathrm{T}$ cells to sites of Leishmania major infection (96). The vast majority of these regulatory cells during the L. major infection expressed the $\alpha_{E}$ chain (CD103) of $\alpha_{\mathrm{E}} \beta_{7}$ intergrin and their results also showed that CD103 is induced and maintained on regulatory cells following or just prior to their arrival in tissues.

Many studies have also reported on the expression of CD62L by $\mathrm{CD} 4^{+} \mathrm{CD} 25^{+} \mathrm{T}$ cells. The CD62L antigen is a $74 \mathrm{kDa}$ glycoprotein and is a member of the selectin family of cell surface molecules, also referred to as L-selectin, LECAM-1, or LAM-1. CD62L binds a series of glycoproteins, including CD34, GlyCAM-1 and MAdCAM-1 that are expressed by high endothelial venules (HEV). CD62L is important for homing 
of naive lymphocytes via the high HEV to peripheral lymph nodes and Peyer's patches, as well as into chronically inflamed tissues through HEV-like structures (97). The CD62L molecule also contributes to the recruitment of leukocytes from the blood to areas of inflammation. Most hematopoietic cells express CD62L including most peripheral blood B cells, T cells, monocytes, granulocytes and some myeloid cells from bone marrow and thymocytes. You et al reported that regulation of autoimmune diabetes was mediated by $\mathrm{CD}^{+} \mathrm{CD} 62 \mathrm{~L}^{+} \mathrm{T}$ cells, which could also be involved in homeostatic mechanisms (98). Other studies show that $\mathrm{CD} 4^{+} \mathrm{CD} 25^{+}$splenocytes that delay the adoptive transfer of diabetes express CD62L (99). $\mathrm{CD} 4{ }^{+} \mathrm{CD} 25^{+} \mathrm{CD} 62 \mathrm{~L}^{+}$cells but not $\mathrm{CD} 4^{+} \mathrm{CD} 25^{+} \mathrm{CD} 62 \mathrm{~L}^{-}$ cells express high levels of the chemokine receptor, CCR7 and migrate toward secondary lymphoid tissue chemokines (SLC), where they could inhibit activation of autoreactive effector cells. Such studies show that $\mathrm{CD} 4^{+} \mathrm{CD} 25^{+} \mathrm{CD} 62 \mathrm{~L}^{+}$, unlike $\mathrm{CD} 4^{+} \mathrm{CD} 25^{+} \mathrm{CD} 62 \mathrm{~L}^{-}$ splenocytes delay diabetes transfer (99). Other in vivo studies using models of

autoimmune gastritis and colitis also show that the $\mathrm{CD}_{6} 2 \mathrm{~L}^{+}$population is far more potent and suppressive than the $\mathrm{CD} 62 \mathrm{~L}^{-}$population, and are concomitantly more responsive to chemokine-driven migration to secondary lymphoid organs (100).

\section{CD28/B7-1/B7-2/CTLA-4 and regulatory $T$ cells.}

It has been observed that regulatory $\mathrm{T}$ cells are readily found both in the thymus and the periphery of mice expressing transgenic clonotypic (MHC class II restricted) TCR but are lost upon back-crossing onto a RAG-deficient background (8), implying a role for TCR specificity as a determining factor in regulatory T cell development. The binding of B7-1 (CD80) and B7-2 (CD86) which are expressed on APC to CD28 on T 
cells induces a strong co-stimulatory signal which plays a major role in $\mathrm{T}$ cell activation. In contrast to CD28, CTLA-4 is only expressed on activated, and not resting, T cells and binds to B7-1 and B7-2 with high affinity to provide a negative or inhibitory signal. Other studies show that B7/CD28 interactions appear to promote the thymic development and peripheral homeostasis of regulatory T cells (58). In such studies, comparing thymic $\mathrm{CD}^{+} \mathrm{CD} 25^{+}$T cells in WT and CD28-deficient mice demonstrated that disruption of the CD28/B7 pathway resulted in a significant $80 \%$ reduction in the levels of $\mathrm{CD} 4{ }^{+} \mathrm{CD} 25^{+}$in the thymus. Similarly, treatment of mice with a combination of B7 blocking antibodies (anti-B7-1 and anti-B7-2 Abs) for 10 days reduced the number of regulatory $\mathrm{T}$ cells in the thymus by $66 \%$ compared with PBS-treated controls. $\mathrm{CD} 4{ }^{+} \mathrm{CD} 25^{+}$regulatory $\mathrm{T}$ cells constitutively express CTLA-4 $(35,101)$, which leads to the suggestion that CD28/B7 and/or CTLA-4/B7 interactions may be necessary for the development and/or effector function of regulatory $\mathrm{T}$ cells. For example it has been suggested that signaling through CD28 and/or CTLA-4 via B7.1/B7.2 is required for the development and maintenance of $\mathrm{CD} 4{ }^{+} \mathrm{CD} 25^{+}$regulatory $\mathrm{T}$ cells $(58,101,102)$. Both CD28-deficient mice and B7-1/B72-deficient mice lack $\mathrm{CD} 4{ }^{+} \mathrm{CD} 25^{+}$regulatory T cells, indicating that the development of $\mathrm{CD}^{+} \mathrm{CD} 25^{+}$regulatory $\mathrm{T}$ cells requires B7/CD28 costimulation (101). Some studies have shown that B7-1 and B7-2 have different effects on regulatory T cell function. B7-1, but not B7-2, is required for the regulatory $\mathrm{T}$ cells to inhibit resting human $\mathrm{T}$ cells (68). On the other hand, blockade of B7-2 instead of B7-1 prevented disease progression in some murine disease models (103). In some autoimmune disease models, such as lupus and diabetes, B7-2 plays a role as the dominant costimulatory ligand for the activation of autoreactive effector T cells $(101,104)$. 
Human $\mathrm{T}$ cells with regulatory function can be induced in vitro from naïve cord blood or peripheral $\mathrm{T}$ cells by stimulation with anti-CD3 and anti-CD28 in the presence of TGF$\beta$ (105), while others show that $\mathrm{B} 7$ co-stimulation is required for $\mathrm{CD} 4^{+} \mathrm{CD} 25^{-}$cells to spontaneously convert into $\mathrm{CD} 4{ }^{+} \mathrm{CD} 25^{+}$regulatory $\mathrm{T}$ cells in vivo (17), because $\mathrm{CD} 4{ }^{+} \mathrm{CD} 25^{-}$cells transferred into B7-/- mice failed to convert into $\mathrm{CD} 4+\mathrm{CD} 25^{+}$cells that exhibit the regulatory phenotype. In summary, the above data demonstrate that CD28/B7 and CTLA-4/B7 signaling pathways may be essential for regulatory cell development and/or function.

\section{Relationship between sex steroids and autoimmune disease.}

Within the past two decades, there has been intensive investigation on why autoimmune diseases such as rheumatoid arthritis, multiple sclerosis and systemic lupus erythematosus are more prevalent in women compared with men, irrespective of the fact that women are generally known to have more potent immune responses compared with men. For example, females mount higher antibody responses to many microorganisms and elicit more vigorous $\mathrm{T}$ cell activation than males. Furthermore, the proinflammatory (IL-1 secretion) and TH1 (IFN- $\gamma$ ) secretion) responses observed in females are also greater than those observed in males $(106,107)$. The discrepancy between the sexes could occur from the influence of sex chromosomes, sex hormones and/or a complex influence of neuronal and endocrine pathways (108). Furthermore, fluctuations of multiple sclerosis and systemic lupus erythematosus disease activity during pregnancy has suggested that sex hormones could modulate autoimmunity (109-113). Research has shown that the phenomenon observed in female mice is reminiscent of that in female human beings and may be mediated by sex hormones (114-119) through mechanism(s) 
which are currently unknown. It has long been suspected that naturally fluctuating levels of estrogens influence different autoimmune diseases by different mechanisms, resulting in women on the average being 2.7 times at greater risk than men to acquire autoimmune disease in general. In recent epidemiological studies carried out by the American Autoimmune Related Diseases Association, the autoimmune disease ratios between females and males were as reported in Table 1. This obvious discrepancy of autoimmune disease prevalence in females and males also occurs in animal models of autoimmune disease (Voskuhl et al, 1996; Jacobswon et al, 1997; Bebo et al, 1996; Roubinian et al, 1978). For example, a similar phenomenon has been observed in a model of multiple sclerosis, experimental autoimmune encephalomyelitis (EAE) in SJL mice, models of SLE in New Zealand Black (NZB) mice and also models of spontaneous diabetes, (nonobese diabetic NOD mice) $(114,115,117,119)$.

Although the sex steroid hormones, estrogens, testosterone and progesterone all have the same precursor, cholesterol, the differences amongst them arise from the fact that a series of enzymes in different organs act accordingly to generate each end-product. The intermediate metabolites such as dehydroepiandrostenedione (DHEA) (120) and $16 \alpha$-estradiol (121) as well as progesterone, estrogen and testosterone have been proposed to interact with the immune system. Due to their lipophylic nature, steroid hormones can diffuse across the cell membrane, and bind to classical steroid hormone receptors found primarily, but not exclusively intracellularly, $(122,123)$. Some steroid receptors can also be found on the cell membrane (124). When the steroid binds to the intracellular steroid receptor, it results in the translocation of the complex to the nucleus. The steroid/steroid receptor complex then serves as a transcription factor, regulating 
genes which have a binding site for the complex in the promoter region (125). The reaction of tissue/cells to sex steroids is a result of the binding of these hormones to their receptor. How, when and where each particular steroid product influences the immune system is very complex and remains obscure. Many autoimmune diseases, including multiple sclerosis (MS), rheumatoid arthritis (RA), systemic lupus erythematosus (SLE), myasthenia gravis (MG), Sjogren's syndrome and Hashimoto's thyroiditis, are characterized by a distinct female preponderance (112). Disease onset in females typically occurs soon after puberty (126-137). In males, disease onset, when it occurs, usually does so later in life, (age 30-40), coinciding with the age at which serum testosterone levels begin to decline in normal healthy men (138). Additionally, it has been reported that $24 \%$ of male MS patients tested had significantly lower levels of testosterone as compared to age-matched healthy men ((138). Estrogen is thought to contribute to the increased frequency of autoimmune disorders occurring in females by its ability to affect immune organs or cells. Estrogens exert their biological effectṣ through estrogen receptors alpha $(\operatorname{ER} \alpha)$ and beta $(\operatorname{ER} \beta(139)$. The same estrogen binding to the alpha or beta receptors can produce opposite effects in the same system (140). In the lymphocyte population, ERs have been found only in suppressor or cytotoxic $\mathrm{T}$ cell subsets, while helper lymphocytes showed no significant steroid binding, indicating their absence in the latter $(130,135)$. However, mRNAs for ERs were present in both lymphocyte populations. This could imply that in helper lymphocytes the mRNA is probably not translated into the protein receptor itself.

Studies show that the estrogen receptor alpha $(E R \alpha)$ appears to be required for both the development of a full-sized thymus, and in conjunction with a second receptor, 
possibly estrogen receptor beta $(\mathrm{ER} \beta)$, the generation of maximum thymic atrophy in response to estrogens $(127,128)$. The thymus undergoes atrophy and phenotypic alterations when exposed to elevated levels of estrogens during puberty $(126,141)$ and also during pregnancy when estrogens and progestins are high. ER $\alpha$ has also been detected in thymic epithelial cells, thymocytes, macrophages, bone marrow nonhematopoietic cells and B-lymphocyte precursors (129-136). ER $\beta$ on the other hand has been found in bone marrow non-hematopoietic cells, thymus and spleen (129-136). Conflicting data however exists regarding the effects of estrogens; while some data show that estrogens may improve EAE and other autoimmune diseases like adjuvant-induced arthritis in mice (142-144), others show that estrogens exacerbate disease in several models of SLE (145). There is apparently some controversy surrounding the role of estrogens in EAE, SLE and other autoimmune diseases.

On the other hand, androgens and/or gene products from sex chromosomes may be responsible for the decreased susceptibility to autoimmune diseases observed in males (138). Although androgen receptors have been found in many tissues of the immune system, the thymus (thymocytes and thymic epithelium) is the most prominent (146, 147). A role for sex hormones in protection against autoimmunity is supported by changes in disease symptomatology that correspond to alterations in sex hormone levels during pregnancy and exogenous hormone treatment. Studies show that estrogeninduced thymic involution occurs much more slowly than androgen-induced thymic involution (148). The thymus atrophies in response to androgens (126). Castration of adult male mice results in enlargement (hypertrophy) of the thymus $(146,149,150)$ and replacement therapy with physiologic doses of androgens reverses this phenomena (151). 
Androgen-resistant testicular feminization (testicular feminization mouse; Tfm) mice, which have defective androgen receptors, also exhibit significant thymus enlargement (146), indicating that the androgen receptor (AR) probably mediates these changes. Furthermore, such studies indicate that the cellular targets of androgen action in the thymus may include the lymphoid cells (thymocytes) which express AR. Phenotypic analyses of lymphocytes in mice whose thymic epithelium lack the AR have shown androgens suppress normal responses, suggesting that AR expressed by thymic epithelium are also important modulators of thymocyte development, and that thymic epithelial expression of AR is required for androgen effects on thymocyte development (146). Research shows that castration and sex hormone treatment modulate the incidence/exacerbation of disease in many animal models of autoimmune disease (115, 117, 152). The removal of physiologic levels of testosterone from male mice via castration increased EAE disease susceptibility $(116,138)$ and testosterone levels have been shown to be decreased in male mice during EAE relapse (138). However, reconstitution of the castrated mice with androgens reverses the phenomenon $(116,117$, 152). More detailed studies have been performed in recent years to evaluate the potential role of androgen in the prevention/cure of autoimmune diseases like SLE, with results that generally suggest that androgens are responsible for the protection against autoimmune disease. In some of such studies the role of testosterone in the treatment of SLE was emphasized, wherein the administration of various forms of the steroid alleviated SLE, or SLE development was seen to occur if levels of testosterone dropped (87, 117, 153-155). In the Lupus prone NZB x NZW mice, more suppressor cells were 
generated in the presence of testosterone, suggesting their role in protecting susceptible mouse strains from the production of autoantibodies (156).

In other models of autoimmune disease like the Non-obese diabetes mice (NOD), it was shown that the administration of androgen after the onset of insulitis, prevents diabetes in these mice, by preventing the further destruction of the islet (157). In other studies, the oral administration of testosterone prior to the induction of EAE in male rats reduced the incidence and clinical symptoms of EAE in such rats and, when supplemented in vitro, testosterone also inhibited the proliferative response of monocuclear cells to myelin basic protein ((158). Studies in multiple sclerosis patients have also indicated an inverse relationship between serum testosterone concentrations and progress of disease, wherein lower levels of testosterone were found in women with MS compared with controls (159).

Together, these data support the hypothesis that physiologic levels of endogenous androgens, and not estrogens, are protective against autoimmune disease.

\section{Compartments/targets of the immune system influenced by sex steroids.}

Steroid hormones regulate target genes at the level of transcription (160). Hence with the development of ER $\alpha$ and ER $\beta$ knockout mice, $\alpha E R K O$ and $\beta E R K O$, respectively, the double knockout mouse $\alpha \beta E R K O$ and the discovery of the androgen receptor mutant mouse (testicular feminization mouse; Tfm) it is possible to assess how sex steroids regulate certain compartments of the immune system by measuring the expression of certain molecules in those compartments.

Androgens exhibit varying effects on some compartments of the immune system. 
Transforming growth factor beta1 (TGF $\beta 1$ ), for example, has been demonstrated to be produced by T lymphocytes (161) and to have significant immunoregulatory properties. It has been shown that testosterone induces expression of TGF $\beta 1$ in the murine thymus (151). Bone marrow chimera experiments have shown that the thymic epithelium appears to be the target of both androgens and estrogens, and thereby mediates the effects of sex steroids on thymic size and development $(127,146)$. Some reports show that androgen receptor (AR) gene expression in leucocytes is hormonally regulated, thereby influencing the rate of inflammatory diseases (162). In such studies, it was shown that human leucocytes isolated from male cells expressed more (AR) than those from female cells. They investigated whether the gender difference in AR expression was due to genetic or hormonal regulation by studying the influence of hormones on AR expression in a mouse model of androgen deficiency, which was treated with testosterone, estradiol or dihydrotestosterone (DHT). Blood samples were obtained for leucocyte AR expression from females versus males and, using RT-PCR, the investigators found that AR mRNA levels were significantly down-regulated in the leucocytes of androgendeficient mice that were treated with exogenous testosterone, estradiol or DHT. In some studies, the castration of male mice to remove physiological levels of testosterone, suggests that androgen deprivation results in a decrease in the number of mature peripheral $\mathrm{T}$ cells, thus altering the function of the peripheral immune system in such mice (163). Other studies show the effect of testosterone on thymocyte proliferation, the thymus gland and nonthymic lymphoid organs such as monocyte/macrophage function $(141,164,165)$. 
Studies also show that treatment of male mice with 17- $\beta$ estradiol induces changes in the immune system, but not in reproductive organs (166). In such studies, the researchers used the male outbred-CD-1 mouse which is considered to be less 17- $\beta$ estradiol responsive (in terms of reproductive changes) compared to the inbred mouse. The CD-1 mice were treated with $17-\beta$ estradiol or vehicle, and the results indicated that the thymic organ weight/body ratio and thymocyte cellularity decreased with increasing doses of 17$\beta$ estradiol. However, although thymocyte numbers were decreased, no differences were noted in the relative percentages of major thymocyte subsets. In contrast to the diminished thymocyte numbers, $17-\beta$ estradiol increased splenic lymphocyte cellularity, indicating that treatment of CD-1 mice with modest doses of $17-\beta$ estradiol, altered both thymocytes and splenocytes. Estrogens also tend to inhibit both $\mathrm{T}$ and $\mathrm{B}$ cell bone marrow-derived precursors $(128,167)$. Transplantation studies using ER gene-targeted animals indicate that ER $\alpha$ expressed by lymphocyte precursors is important for the hormone-mediated suppression of lymphopoiesis (128).

Although androgens and estrogens influence these immune cells, it has not yet been ascertained whether or not sex steroids have direct effects on peripheral $\mathrm{T}$ cells, or whether the effects on peripheral $\mathrm{T}$ cell activity are mediated through the thymus or other compartments (126).

\section{Possible role of $\mathrm{CD}^{+} \mathrm{CD} 25^{+} \mathrm{T}$ cells and steroids in SLE disease progression.}

It is thought that autoimmune diseases are more prevalent in females because of maternal factors, sex-linked gene inheritance and/or hormonal effects $(57,168,169)$. Systemic lupus erythematosus (SLE) is more prevalent in women than in men with a 
corresponding ratio that may be as high as 9:1, respectively. This ratio tends to be more prominent just after puberty, suggesting that hormones might play a role in SLE susceptibility or exacerbation. Inherent genetic and environmental heterogeneity within human populations hinders comparisons of autoantigen-specific responses between females and males with autoimmune disease. However, inbred animal models of autoimmune disease serve as useful tools for the study of gender-related differences in immune responses (119). For example, the (NZB x NZW)F1 mouse is a good model for the study of gender-related differences in SLE, since only female and not male mice develop SLE-like disease (170).

SLE is a multigenic disease associated with IgG hypergammaglobulinemia, IgG antinuclear antibodies and immune complex (IC)-type glomerulonephritis. (NZB x NZW) F1 mice are an experimental model for SLE. Female (NZB x NZW) F1 mice spontaneously develop an SLE characterized by the formation of antibodies to nucleic acids and the development of a fatal immune complex glomerulonephritis. Studies have shown that sex hormones modulate the expression of autoimmunity in both (NZB x NZW) F1 mice and SLE in humans, with androgens exerting a protective effect, while estrogens exert an opposing effect $(117,171)$.

It has been shown that levels of $\mathrm{CD} 4^{+} \mathrm{CD} 25^{+} \mathrm{T}$ cells are decreased in the peripheral blood of patients with SLE compared with normal individuals (172). Other functional studies have shown that the abrogation of suppression that is mediated by peripheral $\mathrm{CD} 4{ }^{+} \mathrm{CD} 25^{+}$regulatory T cells is a distinguishing feature of systemic SLE, because $\mathrm{CD} 4^{+} \mathrm{CD} 25^{-} \mathrm{T}$ cells from a polygenic model of SLE (MRL/Mp mouse strain), showed reduced sensitivity to suppression by $\mathrm{CD} 4{ }^{+} \mathrm{CD} 25^{+}$regulatory $\mathrm{T}$ cells, and 
therefore exhibited a defect in $\mathrm{CD} 4^{+} \mathrm{CD} 25^{+} \mathrm{T}$ cell regulation (173). Such studies suggest that $\mathrm{CD} 4^{+} \mathrm{CD} 25^{+} \mathrm{T}$ cells and sex steroids could play a possible role in the pathogenesis of SLE through mechanisms which are currently unknown. It is therefore reasonable to hypothesize that sex steroids could influence SLE through their action on $\mathrm{CD} 4{ }^{+} \mathrm{CD} 25^{+} \mathrm{T}$ cells that are required for controlling autoimmunity mediated by autoreactive $\mathrm{T}$ cells. It is, therefore, worthwhile to assess the influence of sex hormones on SLE, by characterizing their effects on regulatory $\mathrm{T}$ cell function between the two sexes. Such studies may provide insight into how androgens affect the onset, progression and/or abrogation of clinical SLE, leading to a possible therapeutic role for $\mathrm{CD}^{+} \mathrm{CD} 25^{+} \mathrm{T}$ cells and androgens in SLE. This could lead to development of novel therapies for the prevention and/or cure of SLE, as well as other autoimmune diseases. 


\section{MATERIALS AND METHODS}

\section{Mice.}

Female and/or male NZB x NZW F1, C57BL/6 (CD45.2 $\left.{ }^{+}\right)$, estrogen receptor knockout, testicular feminization (heterozygous female and wildtype male), B.6SJLPtprc $^{\mathrm{a}}$ Pep3 3 /BoyJ $\left(\mathrm{CD} 45.1^{+}\right)$and (NZB x NZW) F1 mice, were purchased from the Jackson laboratory (Bar Harbor, ME). Mice were bred in a specific pathogen-free facility at the University of Louisville according to institutional animal care and use committee (IACUC) guidelines. Adult mice were used at either 6-8 weeks of age, or ages described.

\section{Gonadectomy and steroid treatment}

Mice were anesthetized at 21 days of age and skin shaved in the mid-back for female, and in the testes area for males. Ovaries were surgically removed after cutting through the skin and peritoneum. The testes were removed by cutting through the skin covering the scrotum, ligation of the testes with surgical sutures, followed by separation of the testes from adjoining blood vessels. Sham surgeries were done in a similar way but without the removal of gonads. For steroid pellet treatment, mice were subcutaneously implanted with 60-day testosterone or vehicle-release pellets (Innovative Research of America, Sarasota, FL) in the upper back with the aid of a trochar, and the incision sealed with a wound clip. Lymphoid organs were then collected at the appropriate time during each experiment and analyzed. 


\section{Adult thymectomy}

For thymectomy, adult mice were anesthetized by intraperitoneal injection with tribromoethanol (Aldrich, Milwaukee, WI). The skin over the anterior part of the ribcage was incised to expose the sternum, and the chest cavity was opened by cutting the first two ribs of the sternum. The two lobes of the thymus were then extracted using forceps and the incision sealed with sutures or wound clips. Mice were kept warm under a heat lamp and retuned to their cages when fully awake.

\section{FACS $^{\circledR}$ analysis and antibodies.}

For FACS ${ }^{\circledR}$ analysis of cells, $1 \times 10^{6}$ lymph node, spleen or thymus T-cells were labeled for 15 min with various combinations and concentrations of antibodies in staining buffer ( Dulbecco's PBS, 0.1\% BSA and 0.01\% $\mathrm{Na}_{2}$ azide). Cells were washed and analyzed on a FACScan ${ }^{\circledR}$ (Becton, Dickinson, CA) or FACSCalibur ${ }^{\circledR}$ (BD, Palo Alto, CA). The following antibody reagents were used: FITC-, PE- and PerCP-anti-CD4, FITC-, PE- and biotinylated anti-CD25, FITC-anti-CD45RB, -CD62L, and -CD45.1, PEanti-CD103, and -CD45.1, biotinylated CD45.2 antibodies and FITC-, PE-, PERCP- and APC-labeled streptavidin, anti-CD3 antibody (Pharmingen, CA), and PE-anti-GITR, and isotype antibodies ( $\mathrm{R} \& \mathrm{D}$ Systems, Minneapolis, $\mathrm{MN}$ ). Intracellular staining with CTLA-4-PE and Foxp3-PE was done as per manufacturer's instructions.

\section{Harvesting of regulatory $\left(C D 4^{+} \mathrm{CD} 25^{+}\right)$and responder $\left(C D 4^{+} \mathrm{CD} 25^{-}\right) \mathrm{T}$ cells.}

Spleen and lymph nodes (LN) were collected from adult mice and cells dissociated using HBSS media without phenol red, supplemented with $2 \%$ heat- 
inactivated charcoal/dextran fetal calf serum (Hyclone, Logan, UT). LN and spleen cells combined and enriched for $\mathrm{CD} 4^{+} \mathrm{T}$ using a $\mathrm{CD} 4^{+} \mathrm{T}$-cell enrichment column $(\mathrm{R} \& \mathrm{D}$ systems). The cells were then labeled with PE-anti-CD25 antibody and incubated with anti-PE beads (Miltenyl Biotech, Auburn, CA). Afterwards, the antibody/bead-treated cells were passed through an automagnetic column (Miltenyl Biotech) and the $\mathrm{CD} 4^{+} \mathrm{CD} 25^{+} \mathrm{T}$ cells separated from the $\mathrm{CD} 4^{+} \mathrm{CD} 25^{-} \mathrm{T}$ cells. This procedure yields $\mathrm{CD} 4^{+} \mathrm{CD} 25^{+} \mathrm{T}$ cells of $>90 \%$ purity. To purify $\mathrm{CD} 103^{+}$cells, pre-purified $\mathrm{CD} 4^{+} \mathrm{CD} 25^{+}$ cells were stained with fluorochrome-labeled anti-CD103 antibody and $\mathrm{CD} 4^{+} \mathrm{CD} 25^{+} \mathrm{CD} 103^{+}$cells sorted by high speed cell sorter (Moflow).

\section{Harvesting of bone marrow cells.}

Bone marrow cells were harvested from the tibias and femurs of donors after cervical dislocation of the mice. The cells were then washed by centrifuging $\left(4^{\circ} \mathrm{C}\right.$, 1000rpm, 10 mins) in HBSS without lysing red blood cells. Mononuclear cells, but not red blood cells were then counted, after which $30 \times 10^{6}$ cells were resuspended in $100 \mathrm{ml}$ cell sort media (CSM) (1X clear HBSS, 1M HEPES, decomplemented FCS, 50mg/ml Pen-Strep) and stained with antibodies from BD Pharmingen). The antibodies used for staining $30 \times 10^{6}$ cells were as follows; $30 \mu 1$ each of biotin anti-CD3, B220, MAC1, Gr-1, $25 \mu 1$ each of c-KIT APC and SCA-1 PE. After a 15 min incubation in the dark, the cells were washed in CSM and stained in SA-FITC for another 15 mins. Cells were then sorted for stem cells by depleting all the biotin-bound T cells, B cells, macrophages and granulocytes, while retaining the stem cells that were double positive for c-KIT and SCA1. The sorted cells were then washed and resuspended in HBSS, ready for injection. 
In other cases, T-cell depleted bone marrow cells were used. After harvesting, washing and counting bone marrow cells as described above, a 1:500 (1 ml) dilution of ascites (CD90.2) specific for Thy 1.2 on T cells, was added to $10 \times 10^{6}$ cells and incubated at $4^{\circ} \mathrm{C}$ for 60 mins. Cells were then resuspended in a 1:10 dilution of complement and incubated for $37^{\circ} \mathrm{C}$ for 60 mins to deplete $\mathrm{T}$ cells. After testing for the depletion of T cells, cells were washed and resuspended in HBSS, ready for injection.

\section{Adoptive transfer of cells.}

The CD45 isotype was used as a marker to track cells in the recipients.

Ten thousand bone marrow stem cells or $5 \times 10^{6} \mathrm{~T}$-cell depleted bone marrow cells from B.6SJL-Ptprc ${ }^{\mathrm{a} P e p} 3^{\mathrm{b}} / \mathrm{BoyJ}$ mice $\left(\mathrm{CD} 45.1^{+}\right)$were injected i.v. into sub-lethally irradiated (550 rads) $\mathrm{C} 57 \mathrm{BL} / 6$ or Tfm $\left(\mathrm{CD} 45.2^{+}\right)$mice. For some experiments, adult mice (6-8 weeks of age) were manipulated and used as recipients, as detailed in results. Lymph node, spleen and thymus (when available) were collected 6-8 weeks after injection. Cells were then either analyzed by FACS ${ }^{\circledR}$ or sorted for use in in vitro assays or for analysis of Foxp3 expression. Absolute cell numbers were determined by direct cell counts and flow cytometric analysis. A dose of $550 \mathrm{rad}$ was used for sublethal irradiation of recipient mice, in preparation for adoptive transfer of bone marrow cells.

\section{In vitro proliferation assay}

$\mathrm{CD} 4^{+} \mathrm{CD} 25^{+}$or $\mathrm{CD} 4^{+} \mathrm{CD} 25^{-} \mathrm{T}$ cells were either used directly or labeled with either anti-CD45.1, anti-CD45.2, anti-CD103 and sorted by a high-speed cell sorter (MoFlo ${ }^{\circledR}$ DakoCytomation, Fort Collins, CO). $\mathrm{CD} 4^{+} \mathrm{CD} 25^{+} \mathrm{T}$ cells, $\mathrm{CD} 4^{+} \mathrm{CD} 25^{+} \mathrm{CD} 103^{+}$, 
$\mathrm{CD} 4^{+} \mathrm{CD} 25^{+} \mathrm{CD} 103^{-}, \mathrm{CD} 4^{+} \mathrm{CD} 25^{+} \mathrm{CD} 45.1^{+}, \mathrm{CD} 4^{+} \mathrm{CD} 25^{+} \mathrm{CD} 45.2^{+} \mathrm{T}$ cells were evaluated for their ability to suppress proliferation by co-culture with $\mathrm{CD}^{+} \mathrm{CD} 25^{-}$responder $\mathrm{T}$ cells $(2000,4000,12000$ or 25000$)$, irradiated spleen cells $\left(1 \times 10^{5}\right.$ or $2 \times 10^{5}$ cells $)$ as antigen presenting cells (APC) and anti-CD3 antibody $(0.5 \mathrm{mg} / \mathrm{ml})$. (The regulatory:responder ratios that were tested in these assays were dependent on the number of regulatory cells recovered, i.e., under some experimental conditions, very few transferred cells were recovered). Cells were cultured in complete media (RPMI 1640, 10\% heat-inactivated FCS, $2 \mathrm{mM}$ glutamine, $10 \mathrm{mM} \mathrm{g} / \mathrm{ml}$ strep, HEPES, $100 \mathrm{U} / \mathrm{ml}$ penicillin G sodium, 100 tomycin sulfate, and $1 \times 10^{-5} \mathrm{M} 2$-mercaptoethanol) at $37^{\circ} \mathrm{C}$ and $5 \% \mathrm{CO}_{2}$ for 3 days. $\mathrm{H}^{3}$ thymidine $(0.5 \mathrm{mCi})$ was added for the last $18 \mathrm{hrs}$. Cells were harvested and $\mathrm{H}^{3}$ thymidine incorporation measured by scintillation counter.

\section{Direct culturing of cells with steroids.}

Varying doses of $10^{7}-10^{11} \mathrm{M}$ dihydrotestosterone (DHT), estradiol (E2) (Sigma Aldrich, USA) diluted in 200 proof ethanol (Aaper Chemical Co, Shelbyville, KY) were used to treat cocultures of $\mathrm{CD} 4^{+} \mathrm{CD} 25^{+} / \mathrm{CD} 4^{+} \mathrm{CD} 25^{-}$cells harvested from adult female or male C56BL/6 mice. The treatment of cocultures with similar dilutions of the vehicle(ethanol) served as controls. APC and 0.5ug antiCD3 were added to the cocultures and incubated for 3 days at $37^{0} \mathrm{C}, 5 \% \mathrm{CO}_{2}$. At the end of three days, $0.5 \mathrm{uCi}$ of $\left[{ }^{3} \mathrm{H}\right] \mathrm{TdR}$ were added to each well and incubated overnight. Cells were harvested and $\mathrm{H}^{3}$ thymidine incorporation measured by scintillation counter. 


\section{Pretreatment of $\mathrm{CD}^{+} \mathrm{CD}^{+} 5^{+} \mathrm{T}$ cells with dihydrotestosterone or estradiol.}

Regulatory T cells were stained with CFSE by incubatinq with $20 \mu \mathrm{M}$ CFSE, for 30 mins at $37^{\circ} \mathrm{C}$ in a dark water-bath. The CFSE-CD $4^{+} \mathrm{CD} 25^{+} \mathrm{T}$ cells were co-cultured overnight in the presence of irradiated spleen cells (APC), $0.5 \mathrm{ug}$ antiCD3 and $10^{-8} \mathrm{M}$ steroid (Sigma Aldrich, USA). At the end of the culture period, the CFSE-CD4 ${ }^{+} \mathrm{CD} 25^{+}$ steroid-treated regulatory T cells were sorted from the APC and washed. The testosterone pretreated regulatory cells were then cocultured with fresh untreated $\mathrm{CD} 4^{+} \mathrm{CD} 25^{-}, \mathrm{APC}$ and antiCD3 for three days. At the end of the culture period, $3^{\mathrm{H}}-$ thymidine was added to each well and cells harvested after $18 \mathrm{hrs}$ to evaluate the degree of regulation by $\mathrm{CD} 4^{+} \mathrm{CD} 25^{+} \mathrm{T}$ cells.

\section{Timed pregnancies and implantation of fetal thymus under the kidney capsule.}

Fetal thymi were harvested at day 14 of gestation of pregnant mice and implanted under the kidney capsule of adult mice. Briefly, mice were anesthesized using tribromoethanol and the dorso-lateral portion of the abdomen of the transplant recipient was shaved and cut through to view the right kidney. The right kidney capsule was then carefully incised and two fetal thymic lobes carefully inserted under the capsule using a micro pipette tip. The cut over the dorso-lateral portion of the abdomen was then sealed with sutures or wound clips. Mice were kept warm under a heat lamp and retuned to their cages when fully awake. 


\section{Monitoring of the mouse estrous cycle for $\mathrm{CD}^{+} \mathrm{CD} 25^{+} \mathrm{T}$ cell numbers and function.}

Briefly, 8 week old female mice were monitored daily for diestrus, proestrus and estrus stages by staining vaginal smears with J-stain and observing under a phase contrast microscope (see Figure 26). The diestrus stage was identified if the slide contained predominantly leukocytes, some nucleated epithelial cells and few/no cornified cells. The estrus stage was identified if the slide contained predominantly flat cornified epithelial cells, few nucleated epithelial cells but no leucocytes. The proestrus stage was identified if the slide contained predominantly nucleated epithelial cells, some leucocytes and few/no cornified epithelial cells. Once the diestrus, proestrus and estrus stages were attained in at least 2 mice/stage, spleen and LN cells from each stage were pooled and enriched for $\mathrm{CD}^{+} \mathrm{T}$ cells using a CD4-enrichment column. The $\mathrm{CD} 4^{+} \mathrm{T}$ cells were incubated with anti-CD25-PE antibody, then anti-PE microbeads, followed by the separation of $\mathrm{CD} 4^{+} \mathrm{CD} 25^{+}$and $\mathrm{CD} 4^{+} \mathrm{CD} 25^{-} \mathrm{T}$ cells on a magnetic column. Varying dilutions of $\mathrm{CD} 4^{+} \mathrm{CD} 25^{+} \mathrm{T}$ cells from each stage were co-cultured for 3 days with a standard number of $\mathrm{CD}^{+} \mathrm{CD} 25^{-}$responder T cells, APC and anti CD3 antibody. At the end of the culture period, 3H-thymidine was added to each well and plates harvested after 18 hrs. $\mathrm{CD}^{+} \mathrm{CD} 25^{+}$cell numbers were analyzed by FACs ${ }^{\circledR}$

\section{Induction and evaluation of SLE}

(NZB x NZW) F1 mice were evaluated for SLE disease progression. Serum collected from tail blood was evaluated monthly for anti-dsDNA antibodies by ELISA. Briefly, high binding microtitre plates (Corning, Acton, MA) coated with $1 \mu \mathrm{g}$ dsDNA in $50 \mu \mathrm{l}$ coating buffer $\left(50 \mathrm{ml} \mathrm{H}_{2} \mathrm{O}, 0.079 \mathrm{~g} \mathrm{Na}_{2} \mathrm{CO} 3,0.146 \mathrm{~g} \mathrm{NaHCO} 3, \mathrm{pH} 9.6\right)$ were 
incubated overnight at $4^{0} \mathrm{C}$ in the dark. After being washed with PBS-Tween20 $(0.1 \%$, $\mathrm{pH}$ 7.2), plates were blocked with blocking buffer and incubated at room temperature for

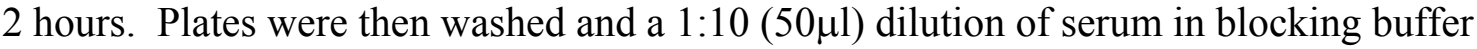
added to each well. Afterwards, plates were incubated at room temperature for 1 hour and washed. $50 \mu 1$ of 1:2000 alkaline phosphate-conjugated goat anti-mouse IgG Fc (Sigma) was added and incubated for 1 hour. After washing, 50ul pNPP alkaline phosphatase substrate was added and incubated in the dark for 15 minutes. After development of color, the optical density (OD) at $405 \mathrm{~nm}$ was determined. Urine samples were collected and evaluated for proteinuria each month using Albustix ${ }^{\circledR}$ reagent and chemistrips (Bayer, IN).

\section{Realtime PCR for Foxp3}

$\mathrm{CD}^{+} \mathrm{CD} 25^{+} \mathrm{T}$ cells, $\mathrm{CD} 4^{+} \mathrm{CD} 25^{+} \mathrm{CD} 103^{+}, \mathrm{CD}^{+} \mathrm{CD} 25^{+} \mathrm{CD} 103^{-}$, $\mathrm{CD} 4^{+} \mathrm{CD} 25^{+} \mathrm{CD} 45.1^{+}, \mathrm{CD} 4^{+} \mathrm{CD} 25^{+} \mathrm{CD} 45.2^{+} \mathrm{T}$ cells were sorted to $>98 \%$ purity. Total RNA was extracted using the Picopure RNA isolation kit (Arcturus, Mountain View, CA), and reverse transcribed using the Taq Man reverse transcriptase kit (Applied Biosystems, Foster City, CA). The cDNA was amplified in duplicate by real-time PCR using the SYBR Green PCR kit (Applied Biosystems, Foster City, CA) with primers for GAPDH and Foxp3. Foxp3 mRNA levels were normalized relative to GAPDH mRNA expression. Data were presented as the fold-change relative to $\mathrm{CD} 4^{+} \mathrm{CD} 25^{-} \mathrm{T}$ cells. Primer pairs were designed using software provided by Applied Biosystems, and synthesized and purified by HPLC by IDT (Coralville, IA). Primer pairs were as follows: 
Foxp3;

5'-CCCACCTACAGGCCCTTCTC-3', 5'-GGCATGGGCATCCACAGT-3'

GAPDH;

5'-GGAGCGAGACCCCACTAACA-3', 5'-ACATACTCAGCACCGGCCTC-3'.

\section{Statistical analyses}

Data were subjected to analyses by either Student's t test or ANOVA and the Tukey-Kramer multiple comparisons test. All experiments were performed at least three times. 


\section{RESULTS}

\section{SPECIFIC AIM I}

\section{Assessing the influence of androgen (dihydrotestosterone) on $\mathrm{CD}^{+} \mathrm{CD} 25^{+}$ regulatory T-cell number, phenotype and function.}

The differences in immune function found in females and males are thought to be associated with sex-specific sex steroids, e.g., estrogens and progesterone in females, and androgens in males (12). Recent studies have shown that these hormones could have opposing effects on the immune system, at physiological levels, i.e., androgens prevent autoimmune diseases, while estrogens exacerbate them (106, 174, 175). Accumulating evidence suggests that the $\mathrm{CD} 4{ }^{+} \mathrm{CD} 25^{+}$regulatory $\mathrm{T}$ cells control autoimmunity in various animal models and human beings as well. We propose that the greater levels of sex steroids after puberty, could influence $\mathrm{CD} 4{ }^{+} \mathrm{CD} 25^{+}$regulatory $\mathrm{T}$ cell number and function, and through this mechanism may influence the differences in autoimmune disease prevalence in females and males. The following study was designed to determine the effect that endogenous and exogenous androgens have on regulatory $\mathrm{T}$ cell numbers, phenotype and function. 


\section{Analysis of phenotype and function of $\mathrm{CD}^{+} \mathrm{CD} 25^{+}$regulatory $\mathrm{T}$ cells from female and male mice.}

In the first series of experiments, $\mathrm{CD} 4{ }^{+} \mathrm{CD} 25^{+}$cells were analyzed in female and male mice. To evaluate the percentage of $\mathrm{CD}^{+} \mathrm{CD} 25^{+} \mathrm{T}$ cells, spleen and lymph nodes (LN) were collected from pre-pubertal (3 weeks) or adult ( $>6$ weeks) female versus male mice of various strains, including C57BL/6, Balb/c, SJL and DO11.10. Cells from spleens and lymph nodes were labeled with PE-anti-CD4 and FITC-anti-CD25 antibodies. Flow cytometric analysis was used to determine the percentage of the $\mathrm{CD} 4^{+}$ $\mathrm{T}$ cell population expressing $\mathrm{CD} 25$ in females versus males. In adult $\mathrm{C} 57 \mathrm{BL} / 6$ mice, the percentages of $\mathrm{CD} 4{ }^{+} \mathrm{CD} 25^{+}$cells were significantly higher in male than female mice in 5 of 7 experiments (Table 2, Figure 1A \& B). In 4 of 7 experiments in SJL mice, the percentages of $\mathrm{CD} 4^{+} \mathrm{CD} 25^{+}$cells in males were also significantly higher than in females (Table 2, Figure 2A \& B). In the results of experiments with Balb/c mice, 1 of 3 showed significant differences, and in the single experiment with D011.10 mice, females also had fewer $\mathrm{CD} 4^{+} \mathrm{CD} 25^{+}$cells (Table 2). There appears to be a trend, in at least some strains of mice, suggesting that males may have significantly more $\mathrm{CD} 4{ }^{+} \mathrm{CD} 25^{+}$cells than females.

Mice (and humans) produce higher levels of sex-specific hormones after puberty. Therefore, to determine whether sex steroids influence $\mathrm{CD} 4{ }^{+} \mathrm{CD} 25^{+}$cells, juvenile (prepubertal) female and male mice were evaluated for the presence of $\mathrm{CD}^{+} \mathrm{CD} 25^{+}$cells. In the three strains evaluated, C57BL/6, Balb/c and SJL, there were no differences in the percentages of $\mathrm{CD}^{+} \mathrm{CD} 25^{+}$cells between females and males (Figure 3). The above results suggest that sex steroids may influence the levels of $\mathrm{CD} 4{ }^{+} \mathrm{CD} 25^{+}$in adult mice. 
$\mathrm{CD}^{+} \mathrm{CD} 25^{+} \mathrm{T}$ cells constitutively express high levels of various molecules that are associated with regulatory function, such as CTLA-4, GITR and CD103. CTLA-4 (CD152) is upregulated in activated T cells, and is generally involved in down-regulating T cell activation and maintaining lymphocyte homeostasis. However, CTLA-4 which is constitutively expressed on $\mathrm{CD} 4{ }^{+} \mathrm{CD} 25^{+}$regulatory $\mathrm{T}$ cells, is co-stimulatory for $\mathrm{CD} 4{ }^{+} \mathrm{CD} 25^{+}$regulatory $\mathrm{T}$ cells (50). Microarray analysis of gene expression, has found that $\mathrm{CD} 4^{+} \mathrm{CD} 25^{+} \mathrm{T}$ cells preferentially express high levels of GITR. Interestingly, ligation of GITR on these cells inhibits immunosuppression mediated by these T cells $(34,35)$. Similar to CTLA-4, although GITR is thought to be a good marker for $\mathrm{CD} 4{ }^{+} \mathrm{CD} 25^{+}$regulatory $\mathrm{T}$ cells, GITR is also upregulated by activated $\mathrm{T}$ cells. The intergrin $\left(\alpha_{\mathrm{E}} \beta_{7}\right), \mathrm{CD} 103$, identifies a subset of $\mathrm{CD} 4^{+} \mathrm{CD} 25^{+}$regulatory $\mathrm{T}$ cells that are not only more suppressive in vitro than the $\mathrm{CD} 103^{-}$cells, but have also been shown to be more effective at suppressing the inflammatory reaction in inflamed tissues in vivo (95). Therefore, with the help of $\mathrm{CD} 103, \mathrm{CD} 4^{+} \mathrm{CD} 25^{+} \mathrm{T}$ cells may be able to traffic to sites of inflammation during an ongoing immune response and regulate inflammation directly. $\mathrm{CD} 4^{+} \mathrm{CD} 25^{+} \mathrm{T}$ cells can also be divided into subsets according to the cell-surface expression of CD62L (L-selectin). CD62L is a member of the selectin adhesion molecule family, and is required for lymphocyte homing to peripheral lymph nodes via binding to sialylated oligosaccharide determinants on high endothelial venules in peripheral lymph nodes $(176,177)$. CD62L is down-regulated upon $\quad \mathrm{T}$ cell activation, and its level of expression, along with other markers, distinguishes naïve $\mathrm{T}$ cells, including $\mathrm{CD} 4{ }^{+} \mathrm{CD} 25^{+}$ cells, from most effector/memory $\mathrm{T}$ cells. The $\mathrm{CD} 4{ }^{+} \mathrm{CD} 25^{+} \mathrm{CD} 62 \mathrm{~L}^{+}$population is more potent as it mediates in vitro suppressive function more effectively than the 
$\mathrm{CD}^{+} \mathrm{CD} 25^{+} \mathrm{CD} 62 \mathrm{~L}^{-}$population (100). Naïve $\mathrm{CD} 4^{+} \mathrm{T}$ cells express relatively high levels of CD45RB (CD45RB hi), in contrast to memory $\mathrm{T}$ cells that express low levels of CD45RB (178) and CD45RB is also downregulated upon activation. Studies have shown that the suppression of $\mathrm{CD} 4^{+} \mathrm{CD} 45 \mathrm{RB}^{\mathrm{hi}}$-induced colitis in immunodeficient mice, is mediated by $\mathrm{CD} 45 \mathrm{RB}^{\text {lo }}$ and a sub-set of these cells is composed of the $\mathrm{CD} 4{ }^{+} \mathrm{CD} 25^{+}$cells (55).

Since CTLA-4, GITR, CD103, CD62L and CD45RB are all associated with the $\mathrm{CD} 4{ }^{+} \mathrm{CD} 25^{+}$regulatory $\mathrm{T}$ cell phenotype, we analyzed the expression of these molecules in several different strains of adult female and male mice by FACS. No differences were detected in the percentage of $\mathrm{CD} 4{ }^{+} \mathrm{CD} 25^{+}$cells expressing CD62L, CTLA-4, GITR or CD45RB (Figure 4A \& B). However, there was a significant difference in the percentage of $\mathrm{CD} 4^{+} \mathrm{CD} 25^{+}$cells expressing CD103, between females and males (Table 3, Figure 4C \& D). In all experiments using adult C57BL/6 and Balb/c mice, the percentages of $\mathrm{CD} 4{ }^{+} \mathrm{CD} 25^{+} \mathrm{CD}_{103^{+}}$cells were significantly higher in male than female mice. In 2 of 4 experiments using SJL mice, the percentages of $\mathrm{CD} 4^{+} \mathrm{CD} 25^{+} \mathrm{CD} 103^{+}$cells in males were also significantly higher than in females, while the data from the other two experiments exhibited a similar trend, although the differences were not statistically significant. To determine whether sex steroids have an effect on CD103 expression, we compared the levels of $\mathrm{CD} 4{ }^{+} \mathrm{CD} 25^{+} \mathrm{CD} 103^{+}$cells in pre-pubertal female and male $\mathrm{C} 57 \mathrm{BL} / 6$ mice. Our results indicated that there was no significant difference in the percentage of $\mathrm{CD} 4{ }^{+} \mathrm{CD} 25^{+} \mathrm{CD} 103^{+}$cells in pre-pubertal female versus male mice (Figure $5 \mathrm{~A} \& \mathrm{~B}$ ). In subsequent experiments, we also evaluated the mean intensity of expression of CTLA-4, GITR, CD62L, CD45RB and CD103 in female and male C57BL/6 mice, to determine the 
levels of expression of each marker per cell based on mean fluorescence intensity. There were no consistent differences in the mean fluorescence intensity of CD103, CD62L, CD45RB or GITR by female and male $\mathrm{CD} 4{ }^{+} \mathrm{CD} 25^{+} \mathrm{T}$ cells (Table 4a, Figure 6A).

However, in all 3 experiments, there was a significant difference in the mean fluorescence intensity of expression of CTLA-4, between females and males; females showed a consistently lower mean fluorescence intensity of CTLA-4 by comparison to males (Table 4a, Figure 6B). We also determined the absolute numbers of $\mathrm{CD} 4^{+} \mathrm{CD} 25^{+}$ or $\mathrm{CD}^{+} \mathrm{CD} 25^{+} \mathrm{CD} 103^{+} \mathrm{T}$ cells in females versus male $\mathrm{C} 57 \mathrm{BL} / 6$, Balb/c and SJL mice. In the majority of experiments using $\mathrm{C} 57 \mathrm{BL} / 6, \mathrm{Balb} / \mathrm{c}$ and $\mathrm{SJL}$, the total numbers of $\mathrm{CD} 4{ }^{+} \mathrm{CD} 25^{+} \mathrm{T}$ cells in males was significantly higher than that in females (Table 5a). In an even larger majority of experiments, the total numbers of $\mathrm{CD} 4^{+} \mathrm{CD} 25^{+} \mathrm{CD} 103^{+} \mathrm{T}$ cells in males was significantly higher than that in females (Table 5b). Taken together, these data suggest that CD103 and CTLA-4 are differentially expressed by $\mathrm{CD} 4{ }^{+} \mathrm{CD} 25^{+}$cells in female and male mice, and their expression may be influenced by sex steroids, which could contribute to the differential autoimmune incidence observed in the females and males.

$\mathrm{CD} 4{ }^{+} \mathrm{CD} 25^{+}$regulatory $\mathrm{T}$ cell function can be detected using a classic in vitro assay (Figure 7). In this assay varying numbers of $\mathrm{CD} 4^{+} \mathrm{CD} 25^{+} \mathrm{T}$ cells are co-cultured with $\mathrm{CD} 4^{+} \mathrm{CD} 25^{-}$responder cells, in the presence of APC and anti-CD3. Functional $\mathrm{CD} 4^{+} \mathrm{CD} 25^{+}$regulatory cells will inhibit proliferation of $\mathrm{CD} 4^{+} \mathrm{CD} 25^{-}$responder cells under these conditions. The following experiments were designed to determine whether there are differences in $\mathrm{CD} 4^{+} \mathrm{CD} 25^{+}$regulatory cell function between adult female and male mice. For these experiments, spleen and LN cells from 8-week-old female or male 
mice were pooled and enriched for $\mathrm{CD} 4^{+} \mathrm{CD} 25^{+}$and $\mathrm{CD} 4^{+} \mathrm{CD} 25^{-} \mathrm{T}$ cells. Female and male $\mathrm{CD} 4^{+} \mathrm{CD} 25^{+} \mathrm{T}$ cells were co-cultured with male $\mathrm{CD} 4^{+} \mathrm{CD} 25^{-}$responder $\mathrm{T}$ cells in the presence of male irradiated spleen cells (APC) and anti-CD3 antibody. $\mathrm{CD} 4{ }^{+} \mathrm{CD} 25^{+}$ T regulatory cell function was tested at various responder: regulatory cell ratios in order to detect any possible subtle but distinct differences in the efficacy of regulatory activity. In 3 of 7 experiments in $\mathrm{C} 57 \mathrm{BL} / 6$ mice, male $\mathrm{CD} 4^{+} \mathrm{CD} 25^{+}$cells were significantly better than female cells in suppressing responder $\mathrm{CD} 4^{+} \mathrm{CD} 25^{-}$cells typically at ratios of $1: 2,1: 4$ and 1:8 (Figure 8A, Table 6a); and in 2 of 5 experiments in SJL mice, male regulatory T cells were better than their female counterparts in suppressing in vitro proliferation also at ratios of 1:2, 1:4 and 1:8 (Table 6b, Figure 8B). Frequently, at lower ratios (1:1) regulator: effector, there were no significant differences in suppression by $\mathrm{CD} 4^{+} \mathrm{CD} 25^{+}$ cells from females versus male mice (Table $6 \mathrm{a}$ and $6 \mathrm{~b}$ ). However, at higher dilution ratios, which are comparable to physiological ratios (e.g., 1:8), significant differences were observed. Although not definitive, overall these results suggest that males may have more regulatory cells and that male $\mathrm{CD} 4^{+} \mathrm{CD} 25^{+}$regulatory cells may function somewhat better than female cells.

\section{Analysis of phenotype and function of $\mathrm{CD}^{+} \mathrm{CD} 25^{+} \mathrm{CD} 103^{+}$cells from female and} male mice.

Previous studies have found in in vitro proliferation assays using subsets of $\mathrm{CD} 4^{+} \mathrm{CD} 25^{+}$cells, that $\mathrm{CD} 103^{+}$is generally expressed by the most potent subpopulation

of $\mathrm{CD} 4{ }^{+} \mathrm{CD} 25^{+}$, because at very low responder : regulatory cell ratios (i.e., ratios that are comparable to physiological conditions), the $\mathrm{CD} 103^{+} \mathrm{CD} 25^{+} \mathrm{CD} 4^{+}$subset exhibits greater 
suppressive effects (31). These data suggest that CD103 identifies a more potent subset of $\mathrm{CD}^{+} \mathrm{CD} 25^{+}$regulatory cells, in addition to its involvement in trafficking to inflamed tissues.

The following experiments were designed to determine whether there are differences in function in the $\mathrm{CD} 4{ }^{+} \mathrm{CD} 25^{+} \mathrm{CD} 103^{+}$cell subset between female and male C57BL $/ 6$ and SJL mice. Female and male $\mathrm{CD} 4^{+} \mathrm{CD} 25^{+} \mathrm{CD} 103^{+} \mathrm{T}$ cells were co-cultured with male $\mathrm{CD} 4^{+} \mathrm{CD} 25^{-} \mathrm{T}$ cells in the presence of male irradiated spleen cells (APC) and anti-CD3 antibody (Figure 7). In the majority of experiments (4 of 5), male $\mathrm{CD}^{+} \mathrm{CD} 25^{+} \mathrm{CD} 103^{+}$regulatory $\mathrm{T}$ cells from $\mathrm{C} 57 \mathrm{BL} / 6$ mice were significantly better than females in inhibiting the proliferation of $\mathrm{CD} 4^{+} \mathrm{CD} 25^{-}$regulatory $\mathrm{T}$ cells at ratios of 1:1, 1:2, 1:4, 1:8 (Figure 9A, Table 7a). However, in SJL mice, in only 1 of 3 experiments, male $\mathrm{CD} 4{ }^{+} \mathrm{CD} 25^{+} \mathrm{CD} 103^{+}$were found to be significantly better than females at suppressing $\mathrm{CD} 4^{+} \mathrm{CD} 25^{-} \mathrm{T}$ cells (Figure 9B; Table 7b). The differences found in $\mathrm{CD}^{+} \mathrm{CD} 25^{+} \mathrm{CD} 103^{+}$regulatory cell function between females and males were greater (i.e., found at ratios as low as 1:1) and more consistent than those found in the unfractionated $\mathrm{CD} 4^{+} \mathrm{CD} 25^{+}$regulatory cell population.

Another characteristic of $\mathrm{CD} 4{ }^{+} \mathrm{CD} 25^{+}$regulatory $\mathrm{T}$ cells is their high expression of the transcription factor, Foxp3, which seems to have a key function in the development of $\mathrm{CD} 4^{+} \mathrm{CD} 25^{+}$regulatory $\mathrm{T}$ cells, and there is a direct correlation between $\mathrm{CD} 4^{+} \mathrm{CD} 25^{+}$ regulatory cell function and Foxp3 expression $(78,81-83,179)$. To determine whether the difference in $\mathrm{CD} 4^{+} \mathrm{CD} 25^{+}$and $\mathrm{CD} 4^{+} \mathrm{CD} 25^{+} \mathrm{CD} 103^{+}$regulatory function between females and males correlates with differences in Foxp3 expression, Foxp3 mRNA from $\mathrm{CD}^{+} \mathrm{CD} 25^{+}$and $\mathrm{CD} 4^{+} \mathrm{CD} 25^{+} \mathrm{CD} 103^{+}$cells was quantified by real-time PCR in $\mathrm{C} 57 \mathrm{BL} / 6$ 
mice. Our results indicated that unlike unfractionated $\mathrm{CD} 4{ }^{+} \mathrm{CD} 25^{+} \mathrm{T}$ cells, where little or no differences in Foxp3 expression was found between females and males (Figure 10A) $\mathrm{CD}^{+} \mathrm{CD} 25^{+} \mathrm{CD} 103^{+}$from males expressed significantly higher levels of Foxp3, compared with females (Figure 10B). Male $\mathrm{CD} 4^{+} \mathrm{CD} 25^{+} \mathrm{CD} 103^{+}$cells expressed 13-fold more Foxp3 than female $\mathrm{CD} 4{ }^{+} \mathrm{CD} 25^{+} \mathrm{CD} 103^{+}$cells. Taken together, the above results suggest that not only do males produce more $\mathrm{CD} 4^{+} \mathrm{CD} 25^{+} \mathrm{CD} 103^{+}$cells which can differentially traffic to sites of inflammation, but these cells also appear to exhibit better regulatory function than female $\mathrm{CD} 4^{+} \mathrm{CD} 25^{+} \mathrm{CD} 103^{+}$cells.

\section{Androgens may modulate $\mathrm{CD} 4^{+} \mathrm{CD} 25^{+}$regulatory $\mathrm{T}$ cell numbers, phenotype and}

\section{function.}

Based on our data showing that adult males may have greater numbers and more effective $\mathrm{CD} 4{ }^{+} \mathrm{CD} 25^{+}$regulatory cells, we hypothesized that sex steroids play a role in these differences. The following experiments were designed to test this hypothesis. Castration of mice dramatically decreases levels of circulating estrogens or androgens in females or males, respectively (116). In the following experiments, pre-pubertal (21 days of age), female or male mice were castrated and the percentage, function and phenotype of $\mathrm{CD} 4{ }^{+} \mathrm{CD} 25^{+}$determined when the mice reached adulthood. Briefly, 4 weeks after castration, lymph nodes from individual mice were collected, and cells labeled with PerCP-anti-CD4, APC-anti-CD25 and PE-CD103 antibodies, then analyzed by FACS ${ }^{\circledR}$. Our results showed that castration of C57BL/6 and SJL males decreased the percentage of $\mathrm{CD} 4{ }^{+} \mathrm{CD} 25^{+} \mathrm{T}$ cells to levels that were comparable to those found in females (Figure 11A \& B, Table 8a). The percentage of $\mathrm{CD}^{+} \mathrm{CD} 25^{+} \mathrm{T}$ cells in $\mathrm{SJL}$ females remained 
unaltered after castration. We did not find any differences in the percentage of $\mathrm{CD}^{+} \mathrm{CD} 25^{+} \mathrm{T}$ cells after castration of Balb/c male, compared with female mice (Table 8a). We also compared the percentages of $\mathrm{CD} 4^{+} \mathrm{CD} 25^{+}$cells from androgen receptordeficient male mice (testicular feminization mice; Tfm) with those from wild-type male mice. Interestingly, we found that the percentage of $\mathrm{CD} 4^{+} \mathrm{CD} 25^{+}$cells was decreased in Tfm mice compared with wildtype mice in 3 of 5 experiments and similar to that found in castrated mice (Figure 12A \& B, Table 8b). These data, therefore, suggest that androgens, and not estrogens may increase the percentage of $\mathrm{CD} 4{ }^{+} \mathrm{CD} 25^{+}$regulatory cells in general.

Next, we analyzed the effects of androgen on surface marker expression by $\mathrm{CD} 4^{+} \mathrm{CD} 25^{+}$cells. $\mathrm{CD} 4^{+} \mathrm{CD} 25^{+}$cells from female, or intact, castrated or Tfm male mice were analyzed for the expression of CTLA-4, GITR, CD62L, CD45RB or CD103. No differences were found in the percentage of $\mathrm{CD} 4^{+} \mathrm{CD} 25^{+}$cells expressing GITR, CD62L or $\mathrm{CD} 45 \mathrm{RB}$ by $\mathrm{CD} 4{ }^{+} \mathrm{CD} 25^{+}$in all of the various groups that were compared (Figure 13A $\& \mathrm{~B})$. However, a significantly higher percentage of $\mathrm{CD} 4{ }^{+} \mathrm{CD} 25^{+} \mathrm{T}$ cells from intact males expressed CTLA-4 and CD103, compared with female, or castrated or Tfm male mice (Figure 13A \& B, Table 9). We also evaluated the mean intensity of expression of CTLA-4, GITR, CD62L, CD45RB and CD103 in female, or intact, castrated or Tfm male mice, to determine the levels of expression of each marker per cell based on mean fluorescence intensity. There were no consistent differences in the mean fluorescence intensity of CD103, CD62L, CD45RB or GITR by female or intact, castrated or Tfm male $\mathrm{CD} 4{ }^{+} \mathrm{CD} 25^{+} \mathrm{T}$ cells in both experiments (Table 4b, Figure 6C). However, in both experiments, there was a significant difference in the mean fluorescence intensity of 
expression of CTLA-4, between males and the rest of the groups; intact males showed a consistently higher mean fluorescence intensity of CTLA-4 by comparison to females, castrated or Tfm males (Table 4b, Figure 6D). Taken together, these data also suggest that both CD103 and CTLA-4 are differentially expressed by $\mathrm{CD} 4^{+} \mathrm{CD} 25^{+}$cells in intact male mice, compared with female or castrated or Tfm male mice, thus reiterating our prior findings that their expression may be influenced by sex steroids.

The experiments described above strongly suggested that androgens may influence the percentages of $\mathrm{CD} 4{ }^{+} \mathrm{CD} 25^{+}$regulatory $\mathrm{T}$ cells. To determine whether androgens could increase the percentage of $\mathrm{CD} 4{ }^{+} \mathrm{CD} 25^{+}$regulatory $\mathrm{T}$ cells in females, sixty-day testosterone (DHT) release pellets or vehicle (control) pellets were implanted subcutaneously into the backs of female pre-pubertal (21day old) C57BL/6 mice that were then euthanized 4-6 weeks later. In 2 of 3 experiments, female mice that received testosterone-release pellets, had significantly higher levels of $\mathrm{CD} 4^{+} \mathrm{CD} 25^{+}$regulatory $\mathrm{T}$ cells, compared with female mice that received only vehicle pellets (Figure 14, Table 8c). The levels of $\mathrm{CD}^{+} \mathrm{CD} 25^{+}$in female mice implanted with testosterone pellets were comparable to those in male mice (Figure 14). The $\mathrm{CD} 4{ }^{+} \mathrm{CD} 25^{+}$cells were also analyzed for CD103 expression, but not CTLA-4, GITR, CD62L, CD45RB, since these other markers did not appear to be affected by androgens in the castration experiments. A significantly higher percentage of $\mathrm{CD} 4{ }^{+} \mathrm{CD} 25^{+}$cells from female mice that were treated with androgen pellets expressed the CD103 phenotype (Figure 15, Table 9). These results indicated that androgens boost both the percentage of $\mathrm{CD} 4{ }^{+} \mathrm{CD} 25^{+}$and $\mathrm{CD}^{+} \mathrm{CD} 25^{+} \mathrm{CD} 103^{+} \mathrm{T}$ cells, further supporting the hypothesis that testosterone may augment the potential of these cells in vivo, as well. 
Having observed that androgens boost both the percentage of $\mathrm{CD} 4^{+} \mathrm{CD} 25^{+}$and $\mathrm{CD} 4{ }^{+} \mathrm{CD} 25^{+} \mathrm{CD} 103^{+}$cells, we also investigated whether the presence or absence of androgens could affect the function of these cells in vitro. We therefore harvested $\mathrm{CD} 4{ }^{+} \mathrm{CD} 25^{+} \mathrm{CD} 103^{+}$from intact female, or intact, castrated or Tfm male mice, or $\mathrm{CD} 4{ }^{+} \mathrm{CD} 25^{+}$cells from androgen pellet-treated female and tested their suppressive capacity in in vitro proliferation assays. In 3 of 3 experiments, proliferation assays performed with $\mathrm{CD} 4{ }^{+} \mathrm{CD} 25^{+} \mathrm{CD} 103^{+}$cells showed that intact $\mathrm{C} 57 \mathrm{BL} / 6$ male mice were significantly better than intact female, or castrated or Tfm male mice in suppressing $\mathrm{CD}^{+} \mathrm{CD} 25^{-} \mathrm{T}$ cells in vitro (Figure 16, Table 10). We also performed three different proliferation assays with $\mathrm{CD} 4{ }^{+} \mathrm{CD} 25^{+}$cells from androgen-pellet treated female $\mathrm{C} 57 \mathrm{BL} / 6$ mice versus naive female and male mice. Our results did not show any significant differences in suppression of $\mathrm{CD} 4^{+} \mathrm{CD} 25^{-}$at regulator: effector dilutions of 1:1, 1:2, 1:4, 1:8, 1:16 and 1:32 (Data not shown).

Although androgens clearly have an effect on $\mathrm{CD} 103$ expression by $\mathrm{CD} 4{ }^{+} \mathrm{CD} 25^{+}$cells, their effect on $\mathrm{CD} 4{ }^{+} \mathrm{CD} 25^{+}$regulatory cell function is less clear.

\section{Androgens do not have a direct in vitro effect on $\mathrm{CD}^{+} \mathrm{CD} 25^{+} \mathrm{T}$ cell function.}

Studies have shown that sex steroids can exert their effect on immune cells by binding to sex-steroid receptors on these cells. In order to evaluate the effect of androgens on $\mathrm{CD} 4{ }^{+} \mathrm{CD} 25^{+} \mathrm{T}$ cells, we first determined by RT-PCR whether these cells express androgen receptor (AR) mRNA. $\mathrm{CD}^{+} \mathrm{CD} 25^{+}$and $\mathrm{CD} 4^{+} \mathrm{CD} 25^{-} \mathrm{T}$ cells from female and male adult mice were sorted to $>98 \%$ purity, mRNA extracted and the androgen receptor mRNA detected by RT-PCR. Androgen receptor mRNA could be 
detected in both $\mathrm{CD} 4^{+} \mathrm{CD} 25^{+}$as wells as the $\mathrm{CD} 4^{+} \mathrm{CD} 25^{-} \mathrm{T}$ cells (Figure 17). These data suggest that androgens could possibly act directly on the $\mathrm{CD} 4{ }^{+} \mathrm{CD} 25^{+}$cells.

The following experiments were designed to determine whether androgens have a direct effect on $\mathrm{CD} 4{ }^{+} \mathrm{CD} 25^{+}$cell function. We tested the in vitro effect of exogenous dihydrotestosterone (DHT) on $\mathrm{CD}^{+} \mathrm{CD} 25^{+}$regulatory $\mathrm{T}$ cells, by assessing whether direct stimulation with DHT during in vitro proliferation assays has an effect on the function of $\mathrm{CD} 4^{+} \mathrm{CD} 25^{+}$regulatory $\mathrm{T}$ cells. $\mathrm{CD} 4^{+} \mathrm{CD} 25^{+} \mathrm{T}$ cells were co-cultured with $\mathrm{CD} 4^{+} \mathrm{CD} 25^{-} \mathrm{T}$ cells in the presence of irradiated spleen cells (antigen presenting cells), anti-CD3 and increasing doses of DHT (Figure 18A), or using the highest dose of DHT and varying ratios of $\mathrm{CD} 4{ }^{+} \mathrm{CD} 25^{+}$regulatory cells (Figure 18B). There was no difference in regulatory function of $\mathrm{CD} 4{ }^{+} \mathrm{CD} 25^{+}$cells treated with either the control vehicle or androgen, or for varying ratios of $\mathrm{CD} 4^{+} \mathrm{CD} 25^{+}$regulatory cells. This could mean that dihydrotestosterone had no direct effect on $\mathrm{CD} 4{ }^{+} \mathrm{CD} 25^{+}$regulatory $\mathrm{T}$ cells in vitro. However, since we had co-cultured both $\mathrm{CD} 4^{+} \mathrm{CD} 25^{+}$and $\mathrm{CD} 4^{+} \mathrm{CD} 25^{-}$cells in the presence of dihydrotestosterone, there was a possibility that dihydrotestosterone was also acting on the $\mathrm{CD} 4^{+} \mathrm{CD} 25^{-}$cells. For this reason, we pre-cultured $\mathrm{CD} 4^{+} \mathrm{CD} 25^{+}$cells with dihydrotestosterone before coculturing with $\mathrm{CD}^{+} \mathrm{CD} 25^{-}$responders. Regulatory cells were labeled with CFSE, so that they could be distinguished from the APC. The $\mathrm{CFSE}^{+} \mathrm{CD} 4^{+} \mathrm{CD} 25^{+} \mathrm{T}$ cells were co-cultured overnight in the presence of irradiated spleen cells (APC), antiCD3 and 10 $0^{-8} \mathrm{M}$ DHT (Sigma Aldrich, USA). At the end of the culture period, the $\mathrm{CFSE}^{+} \mathrm{CD} 4^{+} \mathrm{CD} 25^{+}$DHT-treated regulatory $\mathrm{T}$ cells were sorted from the APC and varying numbers co-cultured with fresh untreated $\mathrm{CD} 4^{+} \mathrm{CD} 25^{\circ}$ cells, APC and anti-CD3. Our results again showed that androgens had no direct effect on 
$\mathrm{CD}^{+} \mathrm{CD} 25^{+}$regulatory cell function in vitro (Figure 19). Based on these data, we concluded that DHT does not have a direct effect on mature $\mathrm{CD} 4^{+} \mathrm{CD} 25^{+} \mathrm{T}$ cells, but may exert their effect on regulatory $\mathrm{T}$ cells through other compartments such as the thymus or at the level of hematopoietic cells.

\section{Androgens influence $\mathrm{CD} 4^{+} \mathrm{CD} 25^{+}$regulatory $\mathrm{T}$ cells through a direct effect on the thymic epithelium.}

As observed in our experiments, androgens do not appear to affect the mature peripheral $\mathrm{CD} 4{ }^{+} \mathrm{CD} 25^{+}$cells directly (at least in vitro), but they may affect the development/differentiation of these cells through an effect on the thymic epithelium. Alternatively, androgens could directly influence these cells at an early stage in their development (i.e., androgens could have an effect on the hematopoietic or bone marrow compartment). Based on the fact that sex steroid receptor mRNA or protein has been found in each of these compartments and each can therefore be affected by sex steroids (129-137, 180), the following experiments were aimed at determining which compartment(s) (i.e, thymic epithelium or hematopoietic) is responsive to sex steroids and produces a quantitative and/or qualitative effect on $\mathrm{CD} 4{ }^{+} \mathrm{CD} 25^{+}$regulatory $\mathrm{T}$ cells. Castration leads to thymic hypertrophy, which can be reversed by sex steroid administration (126). Moreover, steroid receptors have been identified in both thymocytes and thymic epithelium as well as at the level of the bone marrow. These data, coupled with the idea that $\mathrm{CD} 4^{+} \mathrm{CD} 25^{+} \mathrm{T}$ cells are thought to originate in the thymus and subsequently migrate to the periphery to mediate their function, provide a good rationale for performing the following experiments. By creating bone marrow radiation chimeras using wild-type and androgen receptor deficient mice (testicular 
feminization mice, $\mathrm{Tfm}$ ), the thymic and the hematopoietic compartments were tested to determine whether either or both mediate androgen effects on regulatory $\mathrm{T}$ cells.

The following experiments were designed to determine whether the androgens have a direct effect on the hematopoietic (i.e., bone marrow) compartment. Prepubertal (21-day-old) male wild type B6.SJL-ptprca (CD45.1 $\left.{ }^{+}\right)$mice were gonadectomized, and after 4 weeks, the mice were implanted with pellets containing dihydrotestosterone (DHT; androgen) or vehicle control (placebo). One week after implantation of pellets, mice were sub-lethally irradiated and bone marrow stem cells (hematopoietic cells) from Tfm or C57BL/6 (CD45.2 $\left.2^{+}\right)$mice sorted and transferred into DHT or placebo-treated B6.SJL-ptprca $\left(\mathrm{CD} 45.1^{+}\right)$mice. The mice were then euthanized 6 weeks after bone marrow stem cell transfer. Cells were collected from lymphoid organs and the CD45 isotype $\left(\mathrm{CD} 45.2^{+}\right)$was used as a marker to track transferred cells (see Figure 20 for protocol). The percentage of $\mathrm{CD} 45.2^{+} \mathrm{CD} 4^{+} \mathrm{CD} 25^{+} \mathrm{T}$ cells was determined by $\mathrm{FACS}^{\circledR}$, or alternatively, these cells were sorted and analyzed for $\mathrm{CD} 4{ }^{+} \mathrm{CD} 25^{+}$regulatory $\mathrm{T}$ cell function in vitro. We found that although there was a dramatic increase in the percentage of $\mathrm{CD} 45.2^{+} \mathrm{CD} 4{ }^{+} \mathrm{CD} 25^{+}$cells in all mice receiving the DHT pellets compared to the placebo, there were no differences in the percentage of these cells between mice that had received bone marrow from wild-type and Tfm mice (Figure 21A). In these experiments, the comparison is between wild-type and Tfm bone marrow. Therefore, these data suggest that the increase in the percentages of $\mathrm{CD} 4{ }^{+} \mathrm{CD} 25^{+}$cells in response to androgens may not be due directly to an effect on any of the bone marrow (hematopoietic)-derived cells since cells from both androgen-sensitive and androgen-insensitive mice were equally capable of producing increased numbers of $\mathrm{CD} 4{ }^{+} \mathrm{CD} 25^{+}$cells. Interestingly, on 
the other hand, in the functional assays, the $\mathrm{CD} 45.2^{+} \mathrm{CD} 4^{+} \mathrm{CD} 25^{+}$cells from mice injected with the wild-type (C57BL/6) bone marrow cells and subcutaneously treated with DHT (in vivo), exhibited significantly enhanced regulatory activity in vitro by comparison to cells from either the placebo controls or DHT-treated Tfm bone marrow-injected mice (Figure 21B). The inhibitory capacity of the cells from the DHT-treated wild-type bone marrow-injected mice was significantly greater at $\mathrm{CD} 4{ }^{+} \mathrm{CD} 25^{+}$regulatory cell : $\mathrm{CD}^{+} \mathrm{CD} 25^{-}$responder cell ratios of $1: 1,1: 2,1: 4$ and $1: 8$. These data suggest that although androgens may not affect the number of the $\mathrm{CD} 4^{+} \mathrm{CD} 25^{+}$cells by a direct effect on the hematopoietic cells themselves, the androgens do appear to have a positive effect on the development of $\mathrm{CD}^{+} \mathrm{CD} 25^{+}$regulatory cell function.

The following experiments were designed to determine the effect that androgens have on the non-hematopoietic compartment. Pre-pubertal (21 day old) wildtype C57BL/6 (CD45.2 $\left.2^{+}\right)$and $\mathrm{Tfm}\left(\mathrm{CD} 45.2^{+}\right)$mice were subcutaneously implanted with either vehicle (placebo) or dihydrotestosterone (DHT) pellets. After one week, these mice were sublethally irradiated and wild type $\mathrm{T}$ cell-depleted bone marrow cells from male B6.SJL-ptprca (CD45.1) were injected into these mice. The recipient mice were then euthanized 6 weeks after bone marrow transfer (see Figure 22 for protocol). Cells were collected from lymphoid organs and evaluated by $\mathrm{FACS}^{\circledR}$ for the percentage of $\mathrm{CD} 45.1^{+} \mathrm{CD} 4^{+} \mathrm{CD} 25^{+} \mathrm{T}$ cells. In this experiment, the non-hematopoietic environment of Tfm mice (i.e., thymus and other) will not be responsive to androgens, and since the hematopoietic compartment is derived from androgen-sensitive mice, any differences will be due to the effect that androgens have on the non-hematopoietic environment. Interestingly, under these conditions, there were very large differences in the percentage 
of $\mathrm{CD} 4^{+} \mathrm{CD} 25^{+}$cells between wild-type C57BL/6 mice treated with testosterone, and either Tfm mice treated with DHT or wild-type C57BL/6 mice treated with placebo (Figure 23A). Wild-type C57BL/6 mice treated with DHT had much greater percentages of both $\mathrm{CD} 4^{+} \mathrm{CD} 25^{+}$(Figure 23A) and $\mathrm{CD} 4^{+} \mathrm{CD} 25^{+} \mathrm{CD} 103^{+}$cells (Figure 23B) than either Tfm or placebo-treated wild-type mice. These data suggest that some component of the non-hematopoietic compartment that is responsive to androgens can control the percentage of $\mathrm{CD} 4^{+} \mathrm{CD} 25^{+}$cells.

Since $\mathrm{CD} 4^{+} \mathrm{CD} 25^{+}$cells develop primarily in the thymus and the thymic epithelium expresses significant levels of androgen receptor, it is highly likely that the androgens affect the percentage of $\mathrm{CD} 4{ }^{+} \mathrm{CD} 25^{+}$cells through the thymic epithelium. For this reason, the following experiments were designed to test whether androgens affect the percentages of $\mathrm{CD} 4{ }^{+} \mathrm{CD} 25^{+}$cells through the thymus. Pre-pubertal (21-day old) male wild-type B6 mice (CD45.2 $\left.{ }^{+}\right)$were gonadectomized, then 4 weeks later they were thymectomized. Four weeks after thymectomy, these mice were implanted with a fetal (Day 14 of gestation) thymus from either the Tfm (androgen receptor-deficient) or normal littermates (controls). After 2 weeks, the mice were implanted with 60-day sustained release pellets containing either DHT or placebo. Mice were sub-lethally irradiated then injected with wild-type T cell-depleted bone marrow cells from B6.SJLptprca $\left(\mathrm{CD} 45.1^{+}\right)$mice. The recipient mice were then euthanized 6 weeks after bone marrow transfer (see Figure 24 for protocol). Cells were collected from lymphoid organs and evaluated by $\mathrm{FACS}^{\circledR}$ for the percentage of $\mathrm{CD} 45.1^{+} \mathrm{CD} 4^{+} \mathrm{CD} 25^{+}$and $\mathrm{CD} 4^{+} \mathrm{CD} 25^{+}$ $\mathrm{CD}_{103^{+}}$cells. In this experiment, only the wild-type, and not the Tfm, thymus (i.e., lacking a functional androgen receptor), was responsive to the effects of androgen. Wild- 
type C57BL/6 mice that received the wild-type thymus and were treated with DHT pellet exhibited a significant increase in the percentage of $\mathrm{CD} 4^{+} \mathrm{CD} 25^{+}$and $\mathrm{CD} 4^{+} \mathrm{CD} 25^{+} \mathrm{CD} 103^{+}$cells compared to mice receiving either the wild-type thymus and the placebo, or the Tfm thymus and the placebo or DHT pellet (Figure 25A \& B). Taken together, these data suggest that androgens affect the percentage of $\mathrm{CD} 4{ }^{+} \mathrm{CD} 25^{+}$cells at the level of the thymus during $\mathrm{CD} 4{ }^{+} \mathrm{CD} 25^{+}$development in the thymus. On the other hand, androgens appear to influence the functional development of $\mathrm{CD} 4^{+} \mathrm{CD} 25^{+}$ regulatory cells at only a very immature stage in their development (as indicated by the results of treatment at the bone marrow level), since they do not appear to directly affect the function of mature $\mathrm{CD} 4^{+} \mathrm{CD} 25^{+}$cells (in the in vitro assays).

The overall conclusion is that androgens have a dramatic effect on $\mathrm{CD} 4^{+} \mathrm{CD} 25^{+}$ regulatory cell numbers and function in vivo, and it may be through this mechanism that males control autoreactive $\mathrm{T}$ cells more effectively than females. 

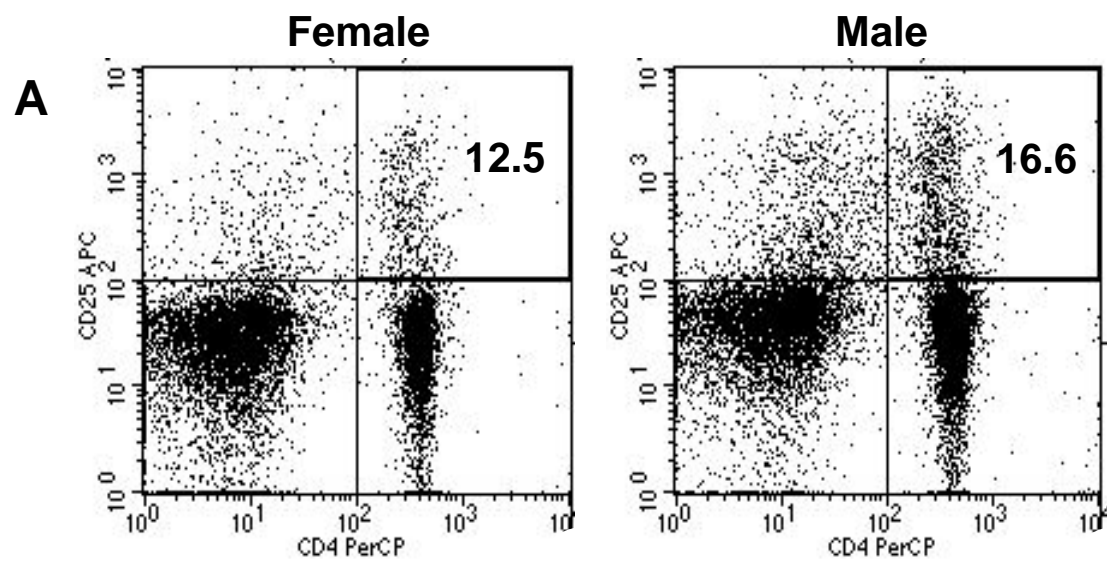

B

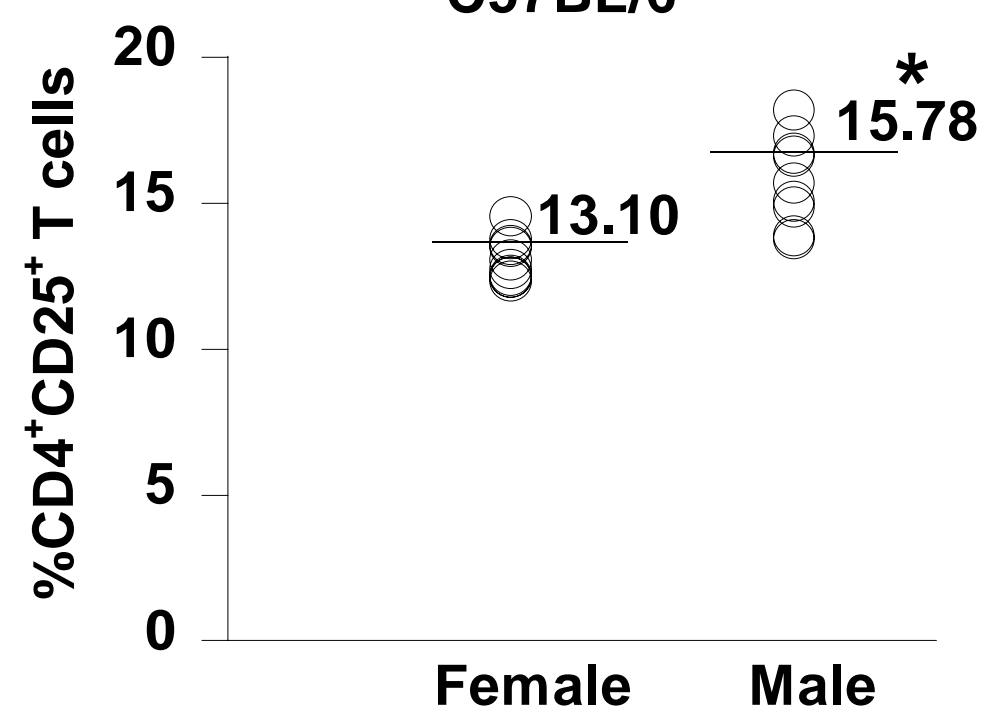

Figure 1. Adult C57BL/6 male mice have significantly more $\mathrm{CD} 4{ }^{+} \mathrm{CD} 25^{+}$cells than females. One million lymph node cells from adult female versus male C57BL/6 mice were labeled with anti-CD4 and anti-CD25 antibodies and analyzed by FACS ${ }^{\circledR}$. Stained $\mathrm{CD}^{+} \mathrm{T}$ cells were gated and analyzed for the expression of the CD25 surface marker $(\mathrm{A})$. The percentage of $\mathrm{CD} 4^{+} \mathrm{T}$ cells that expressed $\mathrm{CD} 25^{+}(\mathrm{B})$ were analyzed by student's t test $(\mathrm{N}=10)$. An $*$ indicates a significant difference at $\mathrm{p}=0.0001$. 

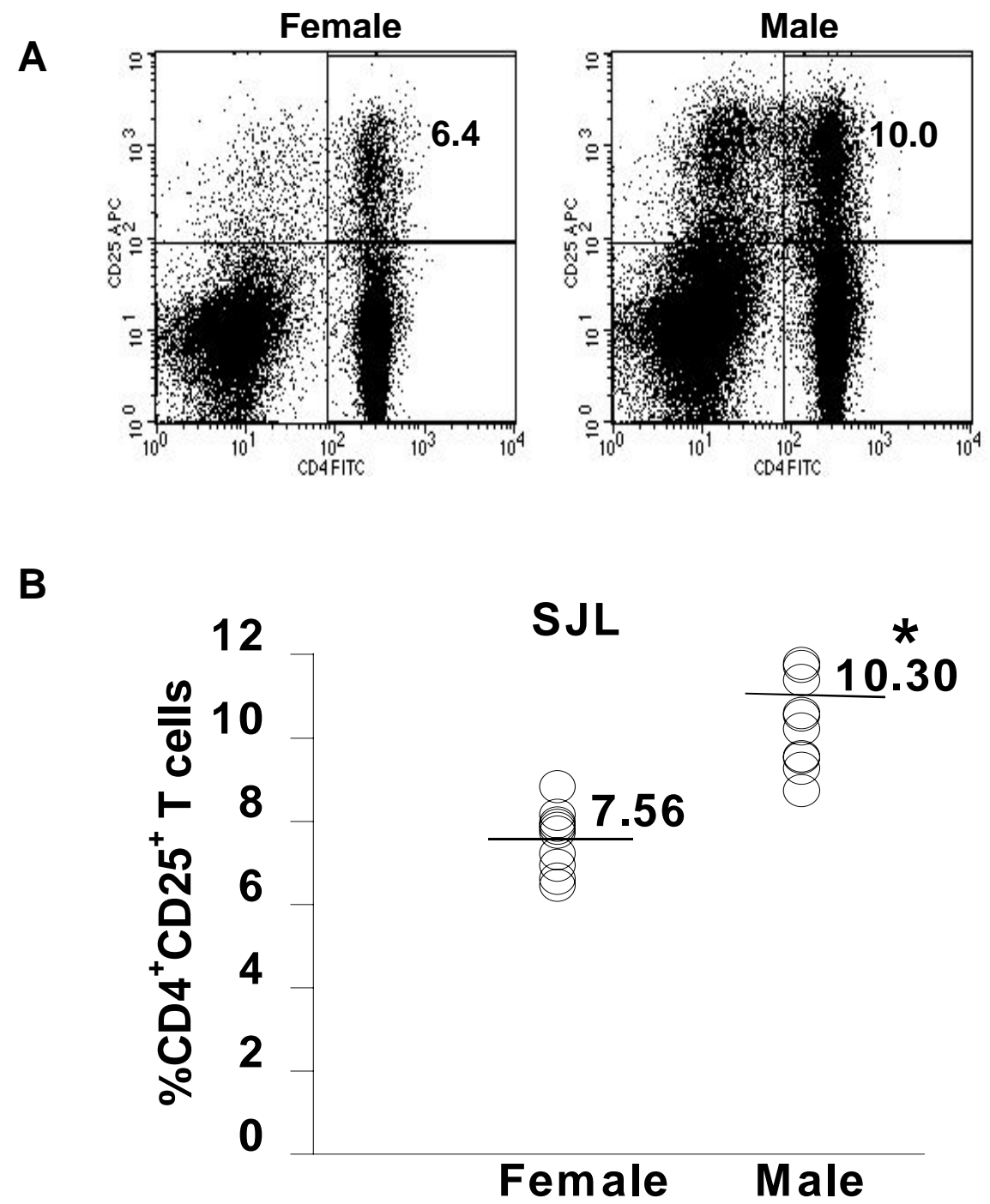

Figure 2. Adult SJL male mice have significantly more $\mathrm{CD} 4{ }^{+} \mathrm{CD} 25^{+}$cells than females. One million lymph node cells from adult female versus male SJL mice were labeled with anti-CD4 and anti-CD25 antibodies and analyzed by FACS ${ }^{\circledR}$. Stained CD4 $4^{+}$T cells were gated and analyzed for the expression of the CD25 surface marker (A). The percentage of $\mathrm{CD}^{+} \mathrm{T}$ cells that expressed $\mathrm{CD} 25^{+}(\mathrm{B})$ were analyzed by student's $\mathrm{t}$ test $(\mathrm{N}=10)$. An * indicates a significant difference at $\mathrm{p}<0.0001$. 
A
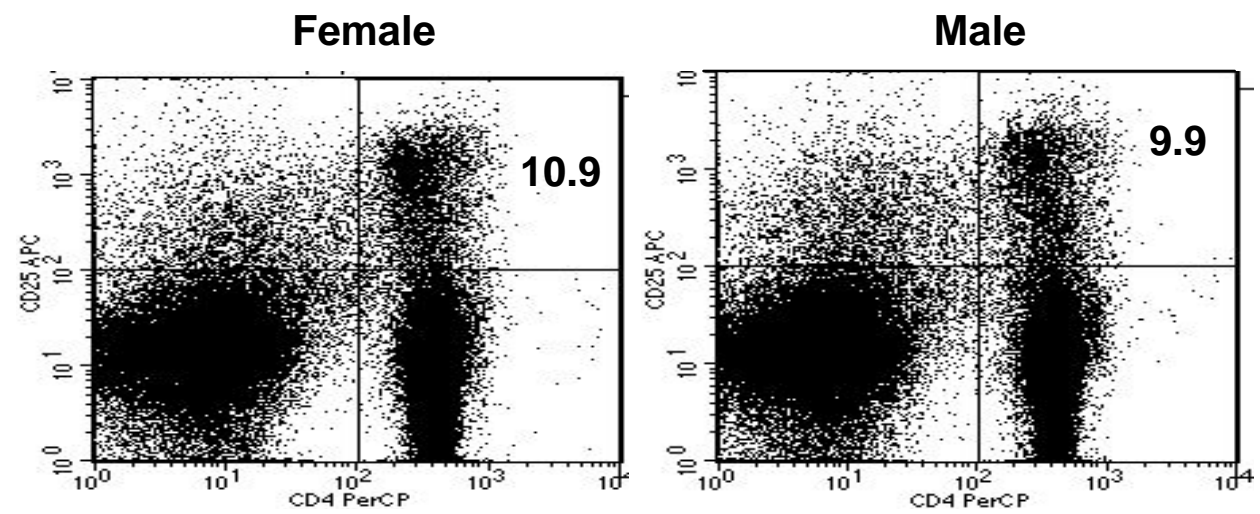

B

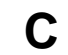

D
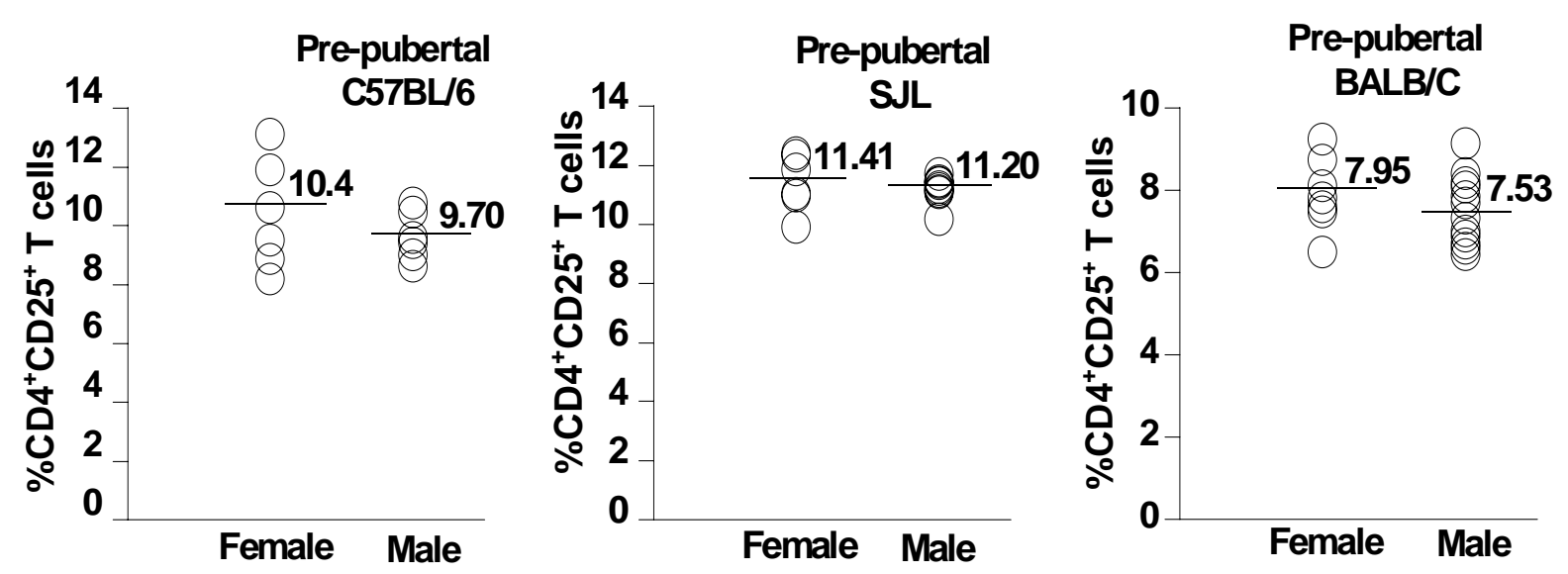

Figure 3. No differences in the percentages of $\mathrm{CD} 4^{+} \mathrm{CD} 25^{+}$cells between pre-pubertal female versus male C57BL/6, SJL and Balb/c mice. One million lymph node cells from pre-pubertal female versus male mice were labeled with anti-CD4 and anti-CD25 antibodies and analyzed by $\mathrm{FACS}^{\circledR}$. Stained $\mathrm{CD} 4^{+} \mathrm{T}$ cells were gated and analyzed for the expression of the CD25 surface marker (A). The percentage of $\mathrm{CD} 4^{+} \mathrm{T}$ cells that expressed $\mathrm{CD} 25^{+}(\mathrm{B}$, C, D) were analyzed by student's $\mathrm{t}$ test $(\mathrm{N}=6$ or 10$) . \mathrm{p}>0.05$. 
A

GITR

CD45RB
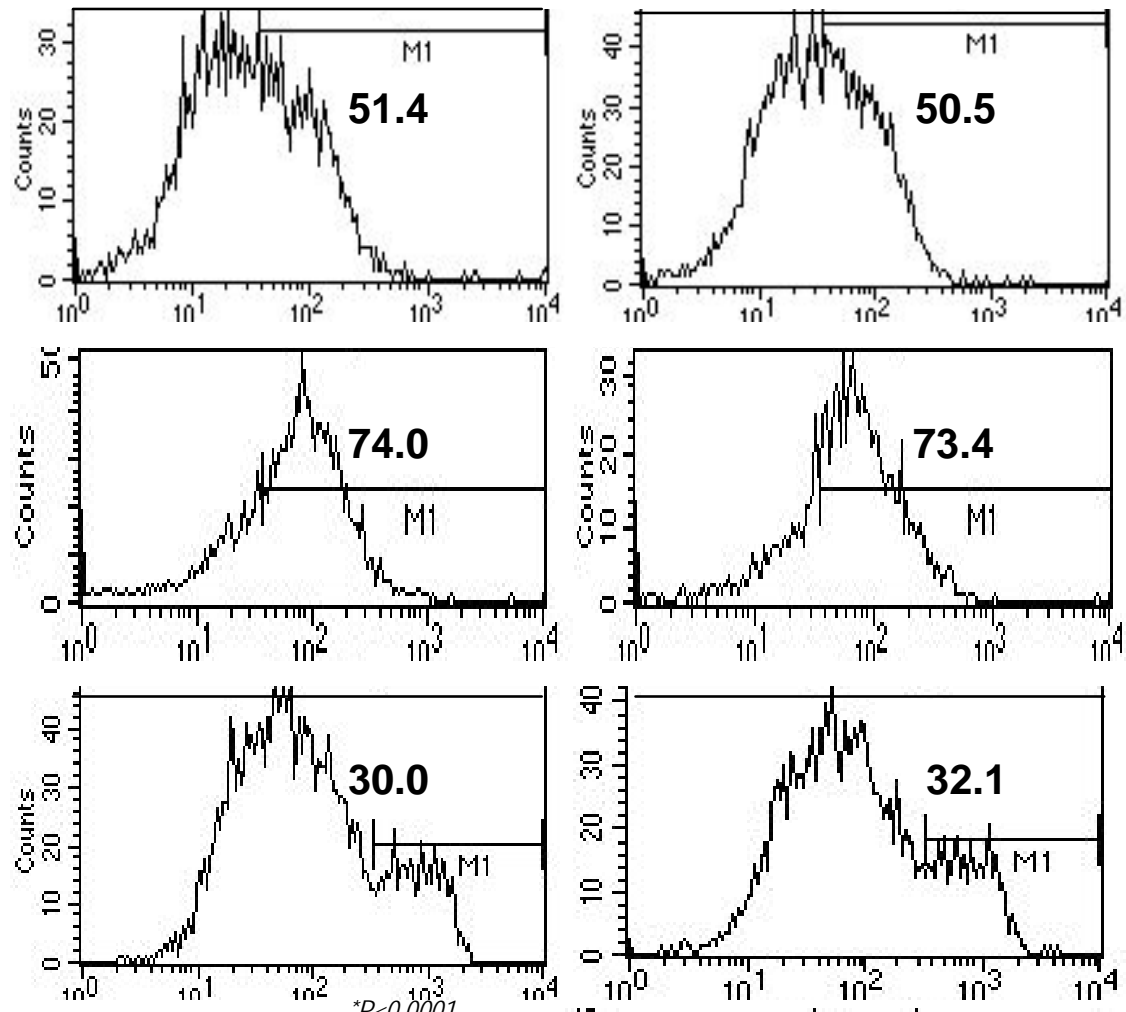

CTLA-4
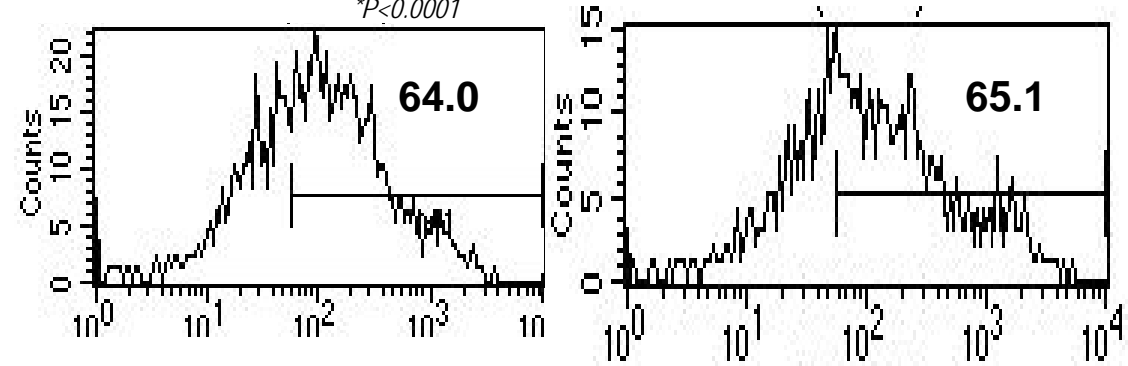

Figure $4 \mathrm{~A} \& \mathrm{~B}$. No differences in the percentage of $\mathrm{CD} 4^{+} \mathrm{CD} 25^{+}$cells expressing CD62L, CTLA-4, GITR or CD45RB between adult female and male C57BL/6 mice.

One million lymph node cells from adult female versus male C57BL/6 mice were labeled with anti-CD4, anti-CD25 and anti-CD62L, CTLA-4, GITR or CD45RB antibodies and analyzed by $\mathrm{FACS}{ }^{\circledR}$. Labeled $\mathrm{CD} 4^{+} \mathrm{CD} 25^{+} \mathrm{T}$ cells were gated and analyzed for the expression of these surface markers (A). The percentage of $\mathrm{CD} 4^{+} \mathrm{CD} 25^{+} \mathrm{T}$ cells that expressed CD62L, CTLA-4, GITR or CD45RB (B) were analyzed by student's t test $(\mathrm{N}=10) . \mathrm{p}>0.05$. 


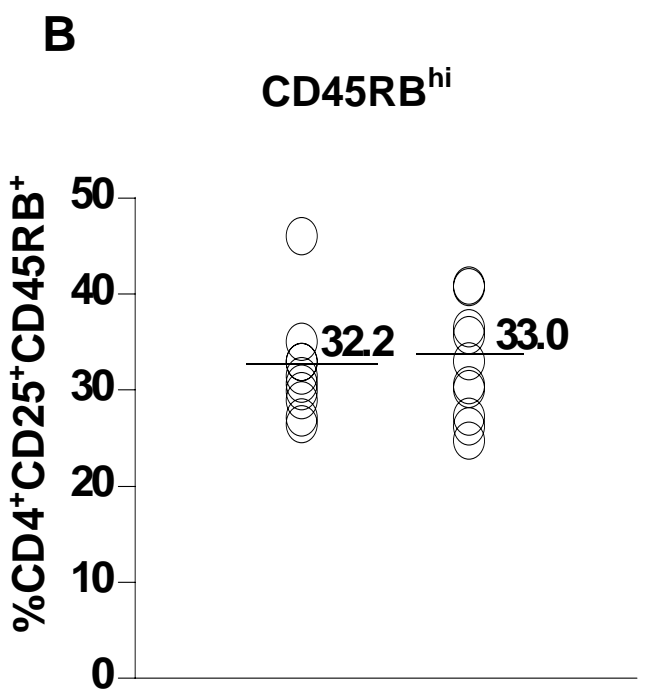

Female Male

GITR $^{+}$

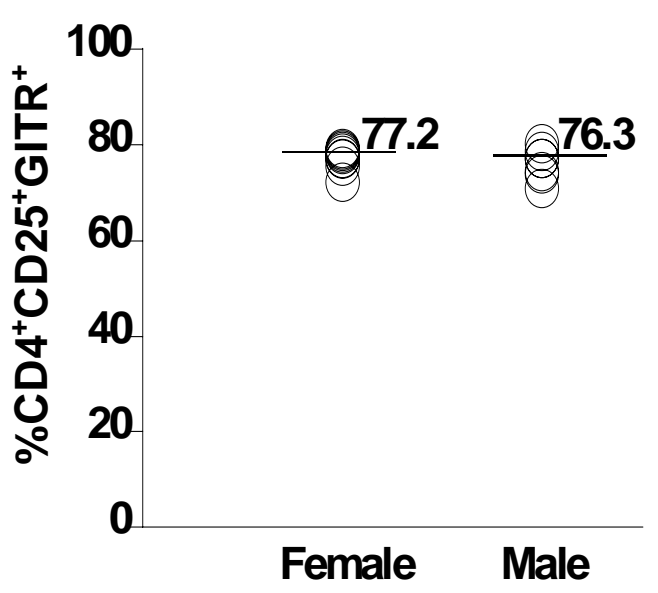

CTLA-4 ${ }^{+}$

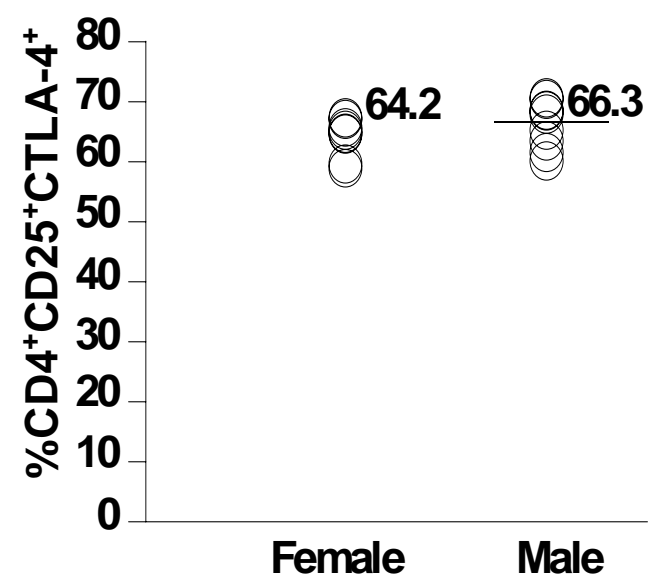

CD62L $^{\text {hi }}$

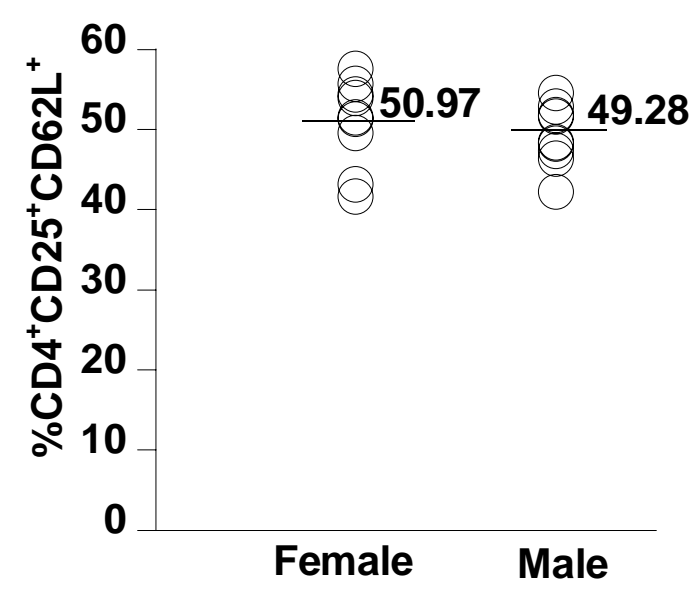




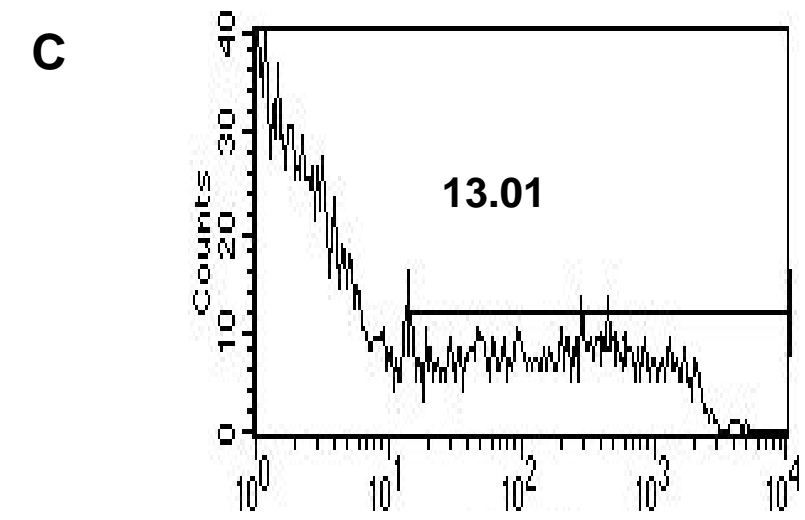

Female

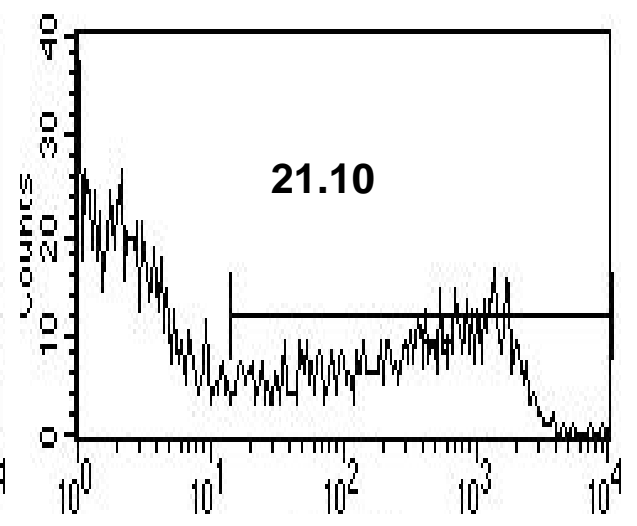

Male

\section{D}
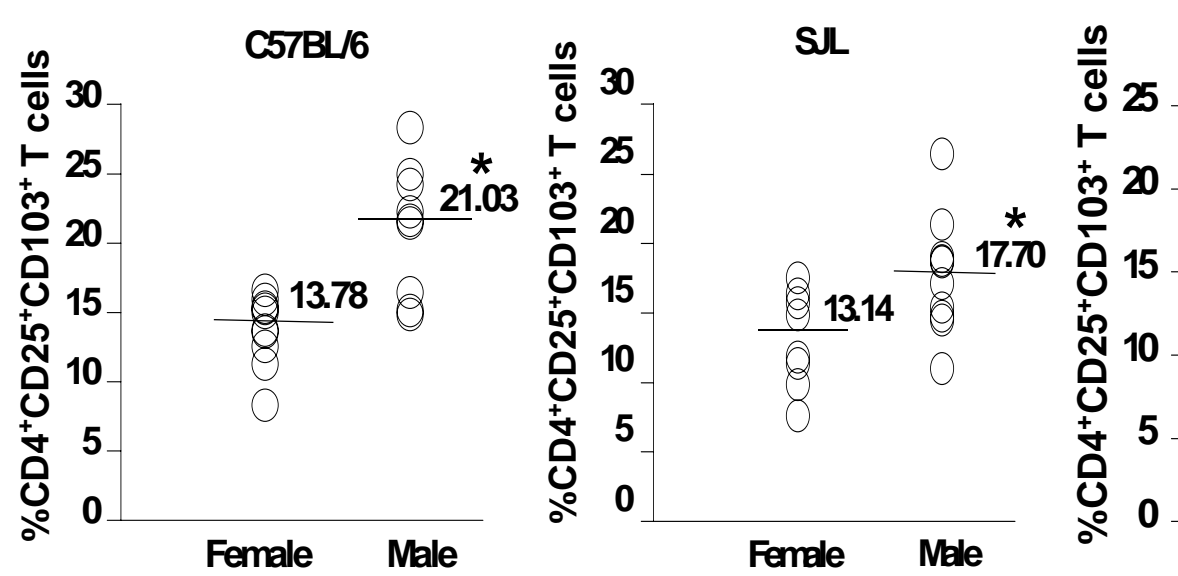

BALCC

Figure $4 \mathrm{C} \& \mathrm{D}$. There are significant differences in the percentage of $\mathrm{CD} 4^{+} \mathrm{CD} 25^{+}$cells expressing CD103 between adult female versus male mice. One million lymph node cells from adult female versus male mice were labeled with anti-CD4, anti-CD25 and CD62L or CTLA-4 or GITR or CD45RB or CD103 antibodies and analyzed by FACS ${ }^{\circledR}$. Stained $\mathrm{CD} 4{ }^{+} \mathrm{CD} 25^{+} \mathrm{T}$ cells were gated and analyzed for the expression of CD103 (C). The percentage of $\mathrm{CD} 4^{+} \mathrm{CD} 25^{+} \mathrm{T}$ cells that expressed CD103 (D), were analyzed by student's t test $(\mathrm{N}=10) . \mathrm{p}<0.05$. 
A
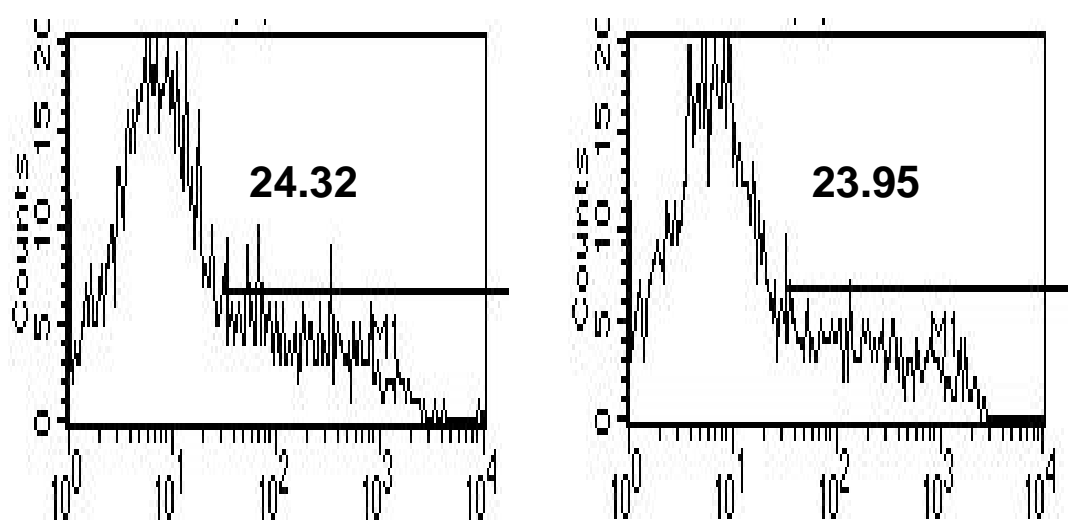

B

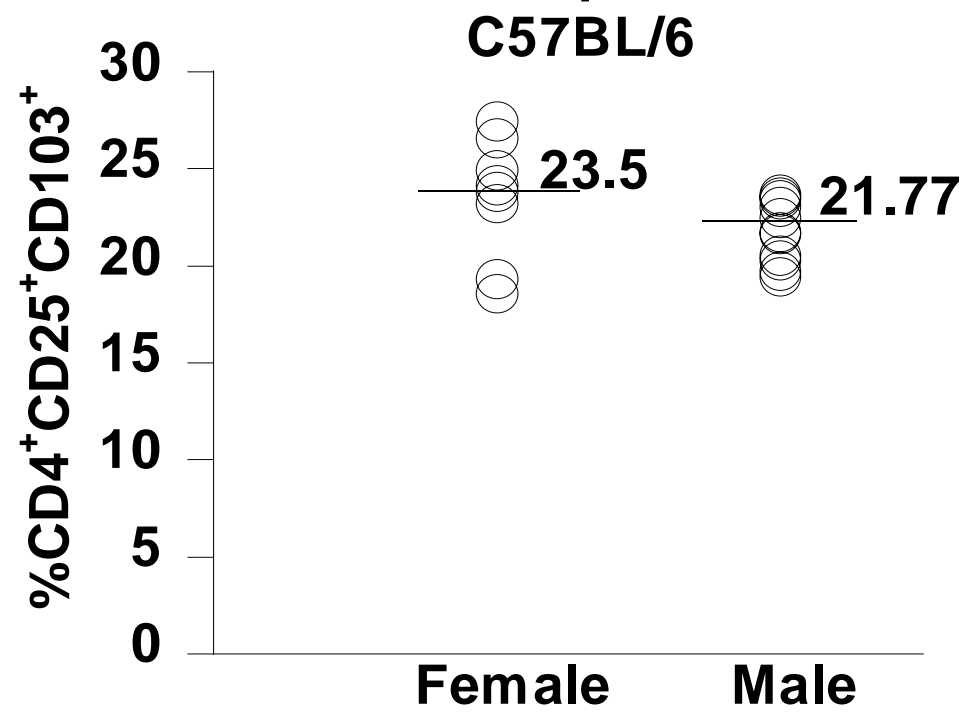

Figure 5. There is no difference in the levels of CD103 expression by

pre-pubertal female and male mice. One million lymph node cells from pre-pubertal female versus male mice were labeled with anti-CD4, anti-CD25 and anti-CD103 antibodies and analyzed by FACS ${ }^{\circledR}$. Stained $\mathrm{CD} 4^{+} \mathrm{CD} 25^{+} \mathrm{T}$ cells were gated and analyzed for the expression of CD103 (A). The percentage of $\mathrm{CD} 4^{+} \mathrm{CD} 25^{+} \mathrm{T}$ cells that expressed CD103 (B), were analyzed by student's t test $(\mathrm{N}=10)$. 


\section{A}
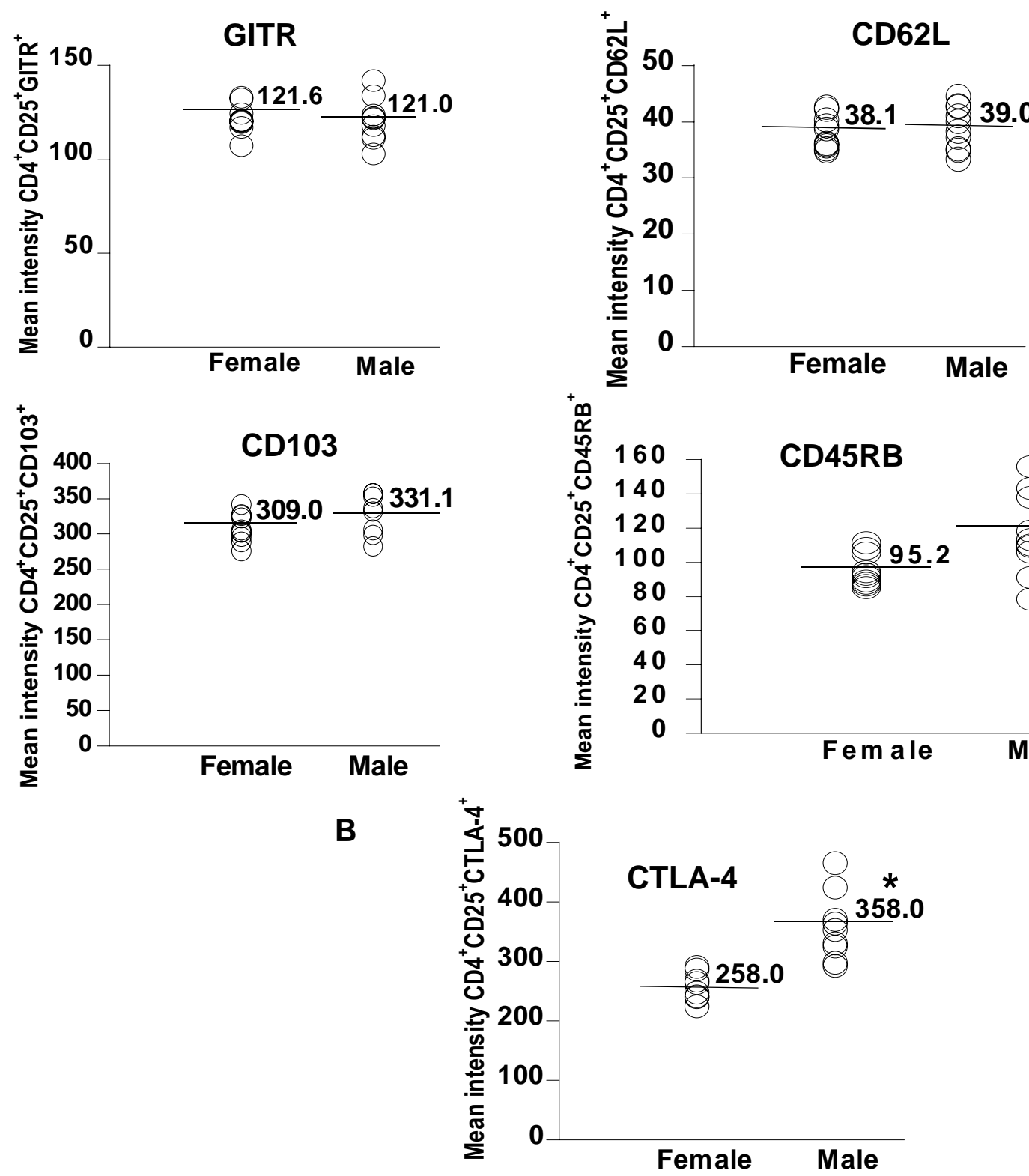

Figure $6 \mathrm{~A} \& \mathrm{~B} . \mathrm{CD} 4^{+} \mathrm{CD} 25^{+} \mathrm{T}$ cells from adult female and male mice do not exhibit significant differences in the mean intensity of expression of CD62L, GITR, CD45RB, or CD103(A), but do exhibit differences in the expression of CTLA-4 (B). One million lymph node cells from adult female versus male mice were labeled with anti-CD4, anti-CD25 and anti-CD62L, CD103, CTLA-4 , GITR or CD45RB antibodies and analyzed by $\mathrm{FACS}^{\circledR}$. Labeled $\mathrm{CD} 4^{+} \mathrm{CD} 25^{+} \mathrm{T}$ cells were gated and analyzed for the mean intensity of expression of CD62L, CD103, CTLA-4, GITR or CD45RB. (N=10). An * indicates a significant difference at $\mathrm{p}<0.05$. 

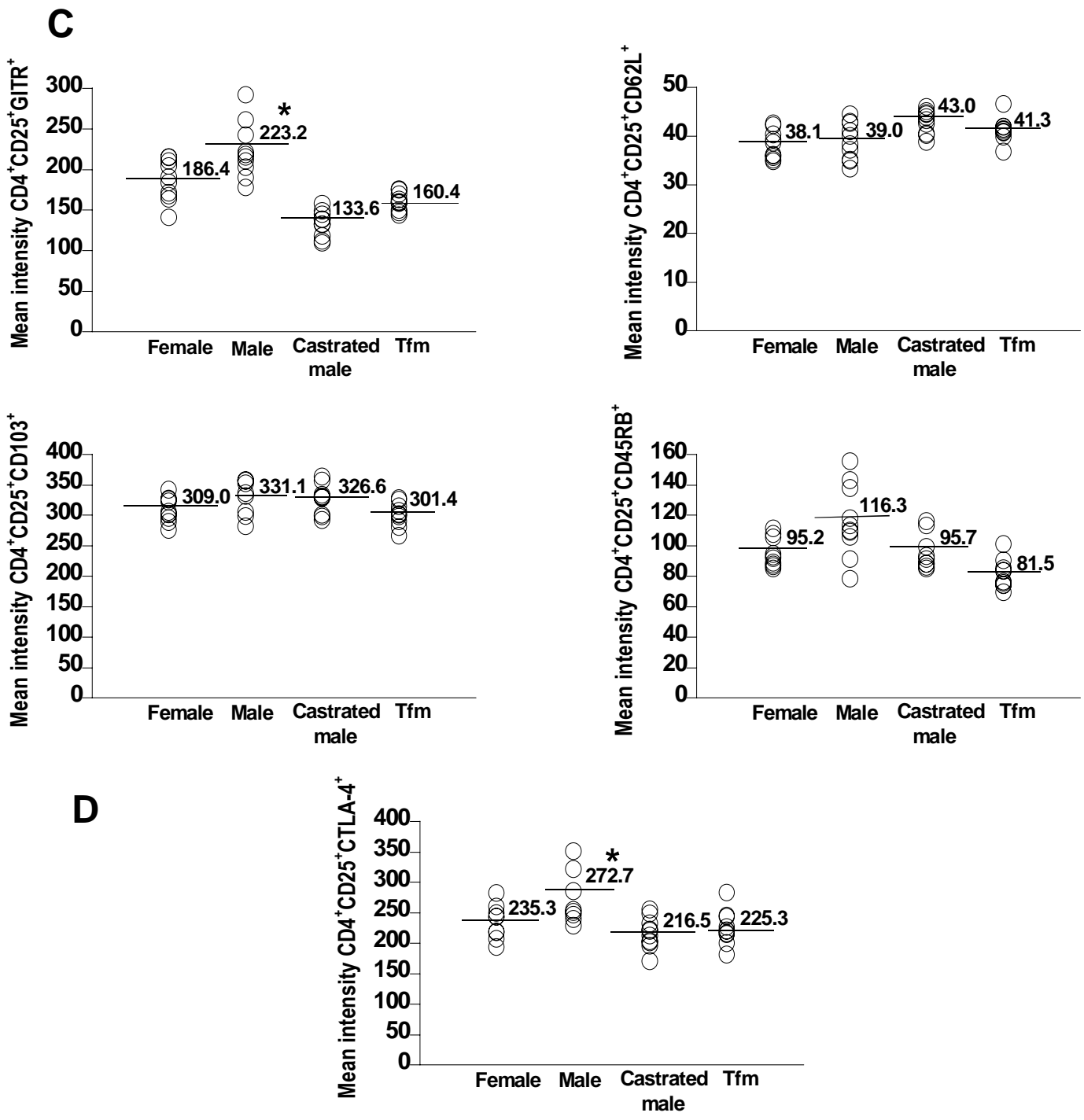

Figure $6 \mathrm{C} \& \mathrm{D} . \mathrm{CD}^{+} \mathrm{CD} 25^{+} \mathrm{T}$ cells from adult female, intact or castrated or $\mathrm{Tfm}$ male mice do not exhibit significant differences in the mean intensity of expression of CD62L, GITR, CD45RB, or CD103 (A), but do exhibit differences in the expression of CTLA-4 (B). One million lymph node cells from adult female, intact or castrated or Tfm male mice were labeled with anti-CD4, anti-CD25 and anti-CD62L, CD103, CTLA-4, GITR or CD45RB antibodies and analyzed by $\mathrm{FACS}^{\circledR}$. Labeled $\mathrm{CD} 4^{+} \mathrm{CD} 25^{+} \mathrm{T}$ cells were gated and analyzed for the mean intensity of expression of CD62L, CD103, CTLA-4, GITR or CD45RB. (N=10). An * indicates a significant difference at $\mathrm{p}<0.05$. 
Constant number of $\mathrm{CD}^{+}{ }^{+}{ }^{2} 25^{-}$responder T cells

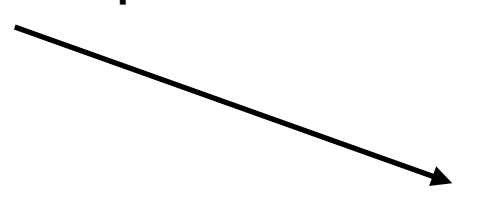

0000000

0000000

0000000

0000000

3 day culture

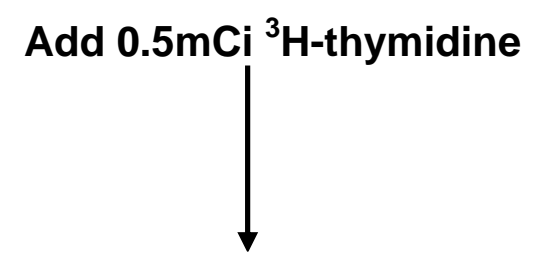

$\mathrm{CD}^{+} \mathrm{CD}^{2} 5^{+}$or $\mathrm{CD} 4^{+} \mathrm{CD} 25^{+} \mathrm{CD} 103^{+}$ regulatory $\mathrm{T}$ cells from various sources.

+ irradiated spleen cells (APC)

$+0.5 \mu \mathrm{g} / \mathrm{ml}$ anti CD3 antibody.

\section{Harvest cells and determine ${ }^{3} \mathrm{H}$-thymidine uptake by $\beta$ - scintillation counter.}

Figure 7. Standard in vitro assay for regulatory $\mathrm{T}$ cell function (proliferation assay).

Varying numbers of $\mathrm{CD} 4^{+} \mathrm{CD} 25^{+}$cells are co-cultured with a constant number of $\mathrm{CD} 4^{+} \mathrm{CD} 25^{-}$responder $\mathrm{T}$ cells, irradiated spleen cells $\left(1 \times 10^{5}\right.$ or $2 \times 10^{5}$ cells $)$ as antigen presenting cells (APC) and anti-CD3 antibody $(0.5 \mathrm{mg} / \mathrm{ml})$ for 3 days. $\mathrm{H}^{3}-$ thymidine $(0.5 \mathrm{mCi})$ is added for the last $18 \mathrm{hrs}$. Cells are then harvested and $\mathrm{H}^{3}$ thymidine incorporation measured by $\beta$-scintillation counter. 
A
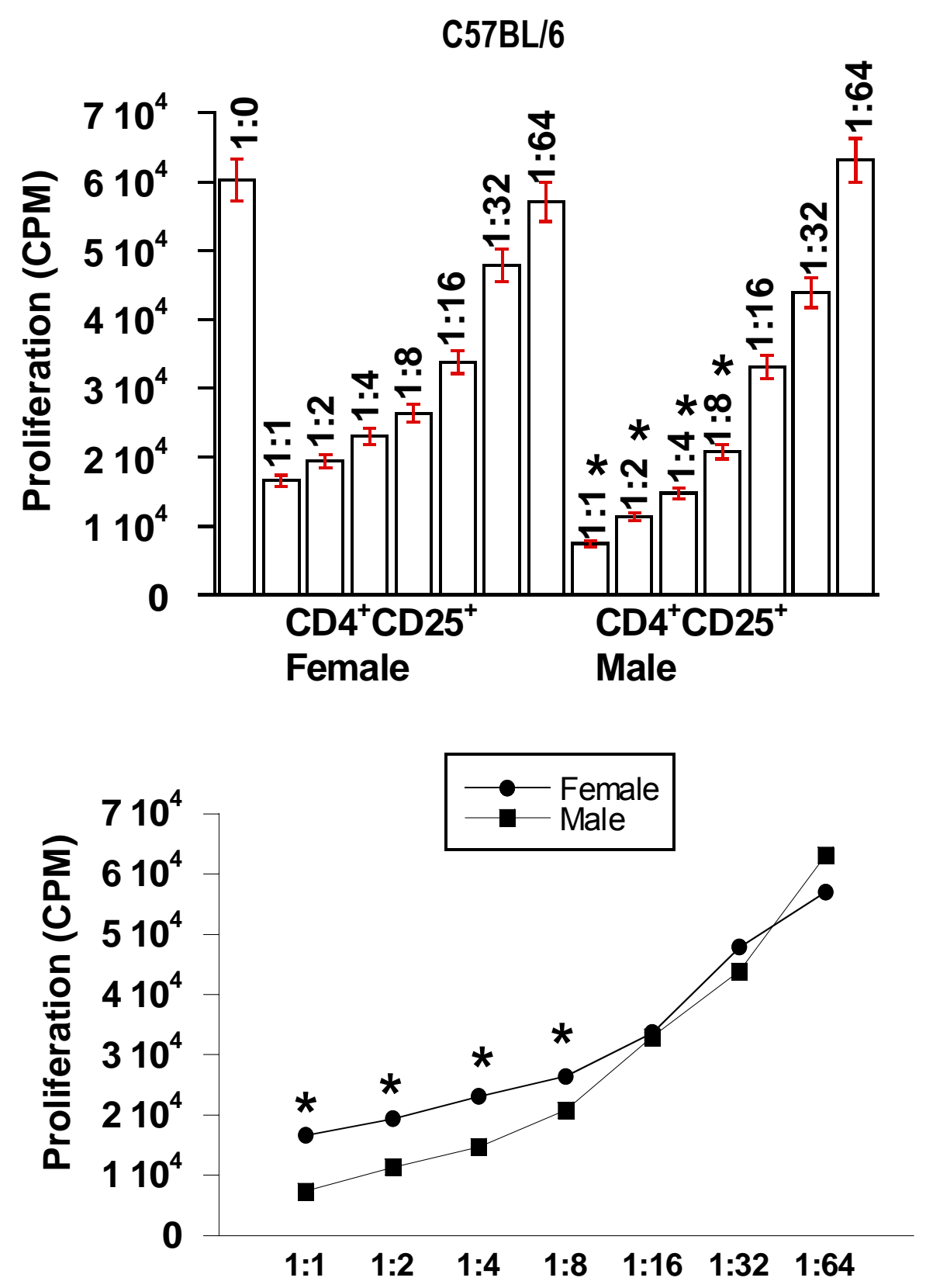

Figure 8. Male $\mathrm{CD} 4{ }^{+} \mathrm{CD} 25^{+}$cells suppress significantly better than female $\mathrm{CD} 4^{+} \mathrm{CD} 25^{+}$cells. Female and male $\mathrm{CD} 4^{+} \mathrm{CD} 25^{+} \mathrm{T}$ cells were harvested from adult C57BL/6 or SJL mice, and co-cultured with male $\mathrm{CD} 4^{+} \mathrm{CD} 25^{-}$responder $\mathrm{T}$ cells in the presence of male irradiated spleen cells (APC) and anti-CD3 antibody. $\mathrm{CD} 4{ }^{+} \mathrm{CD} 25^{+}$ regulatory $\mathrm{T}$ cell function was tested at various responder : regulatory cell ratios in C57BL/6 mice (A) or in SJL (B) mice. An * indicates a significant difference at $\mathrm{p}$ $<0.05$. 
B

SJL
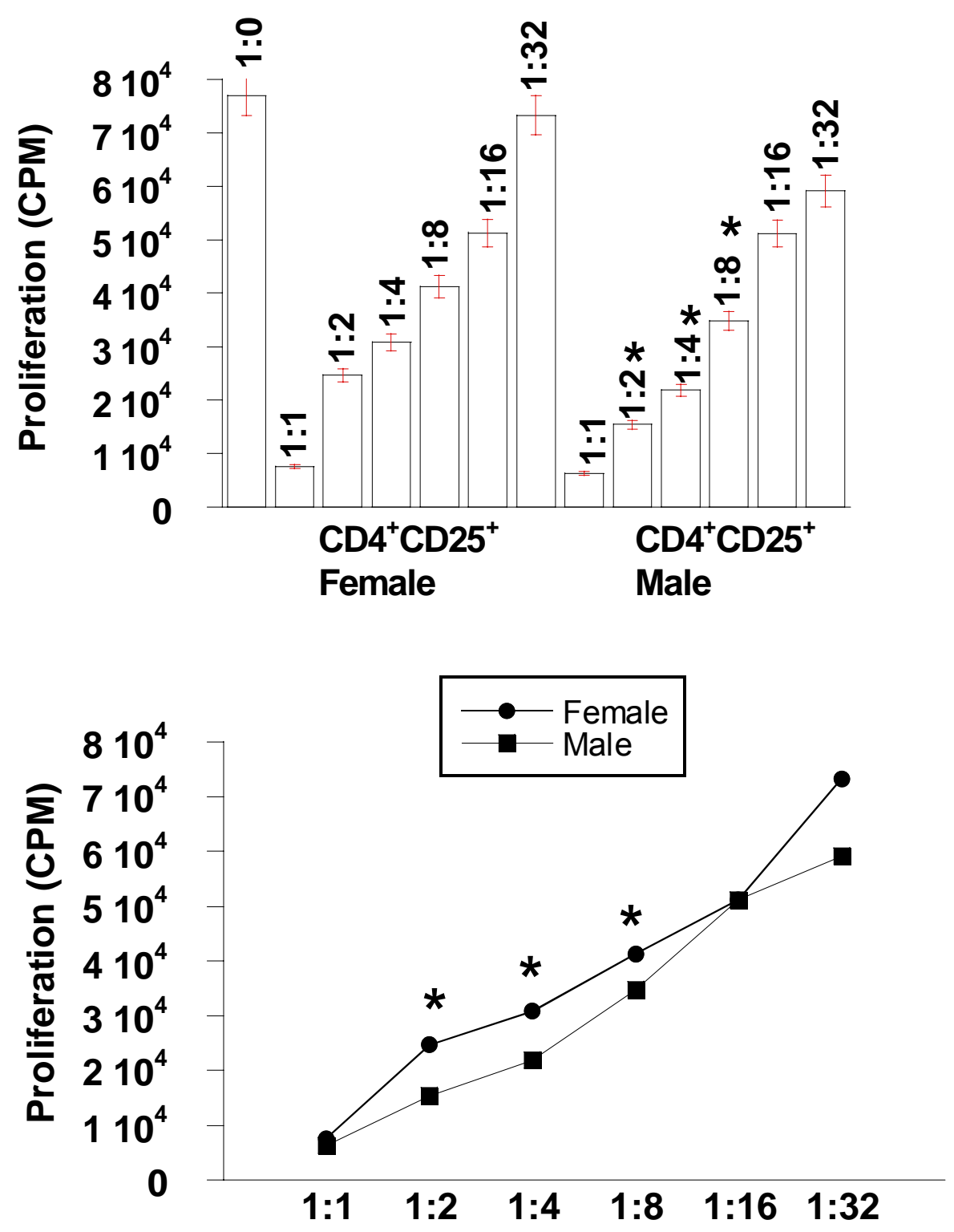


\section{C57BL/6}
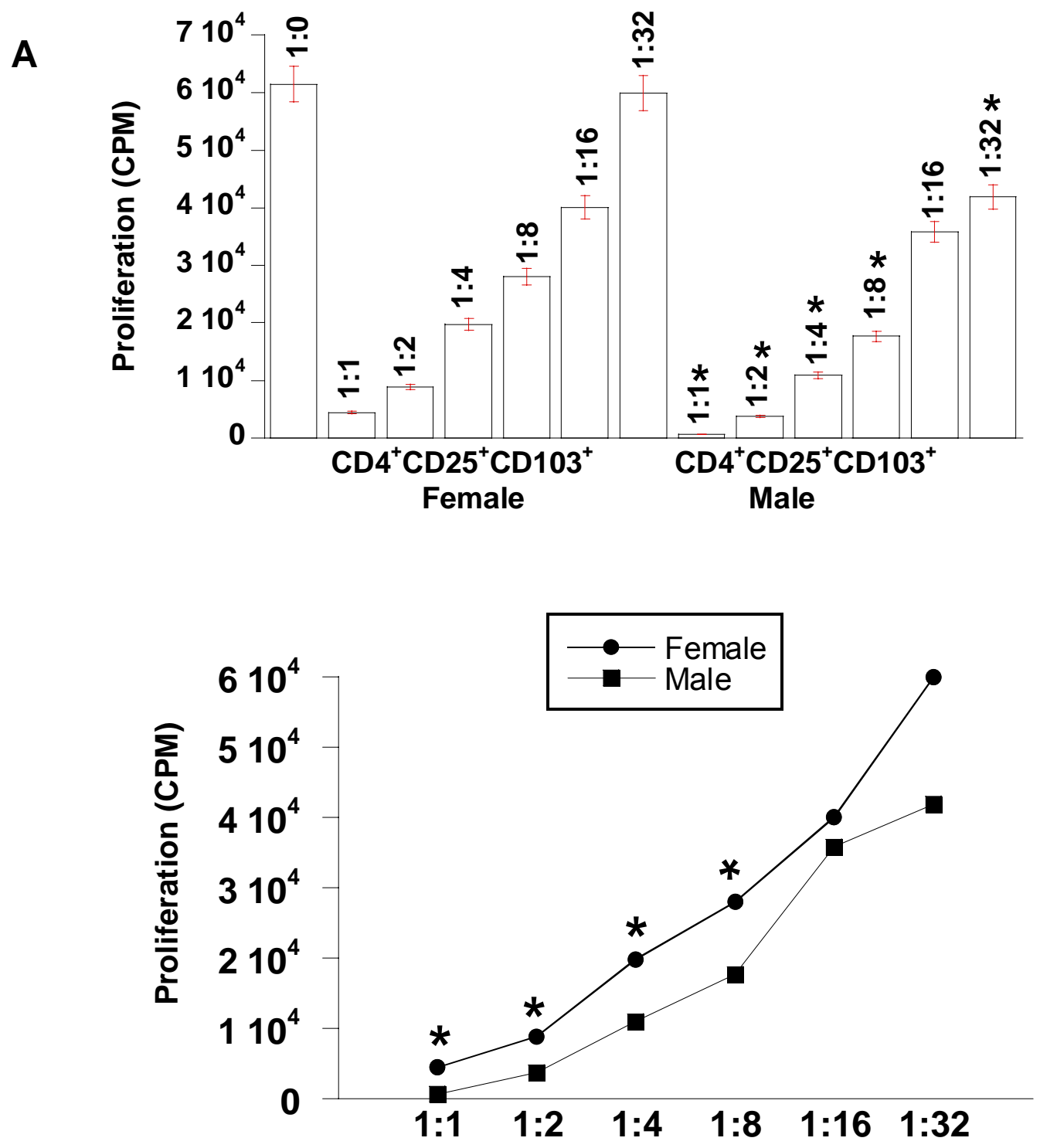

Figure 9. Male $\mathrm{CD} 4^{+} \mathrm{CD} 25^{+} \mathrm{CD} 103^{+}$cells suppress significantly better than female $\mathrm{CD} 4^{+} \mathrm{CD} 25^{+}$ cells. Female and male $\mathrm{CD} 4^{+} \mathrm{CD} 25^{+} \mathrm{CD} 103^{+} \mathrm{T}$ cells were harvested from adult $\mathrm{C} 57 \mathrm{BL} / 6$ or SJL mice, and co-cultured with male $\mathrm{CD} 4^{+} \mathrm{CD} 25^{-}$responder $\mathrm{T}$ cells in the presence of male irradiated spleen cells (APC) and anti-CD3 antibody. $\mathrm{CD} 4{ }^{+} \mathrm{CD} 25^{+} \mathrm{CD} 103^{+}$regulatory $\mathrm{T}$ cell function was tested at various responder : regulatory cell ratios in C57BL/6 mice (A) or in SJL (B) mice. An * indicates a significant difference at $\mathrm{p}<0.05$. 

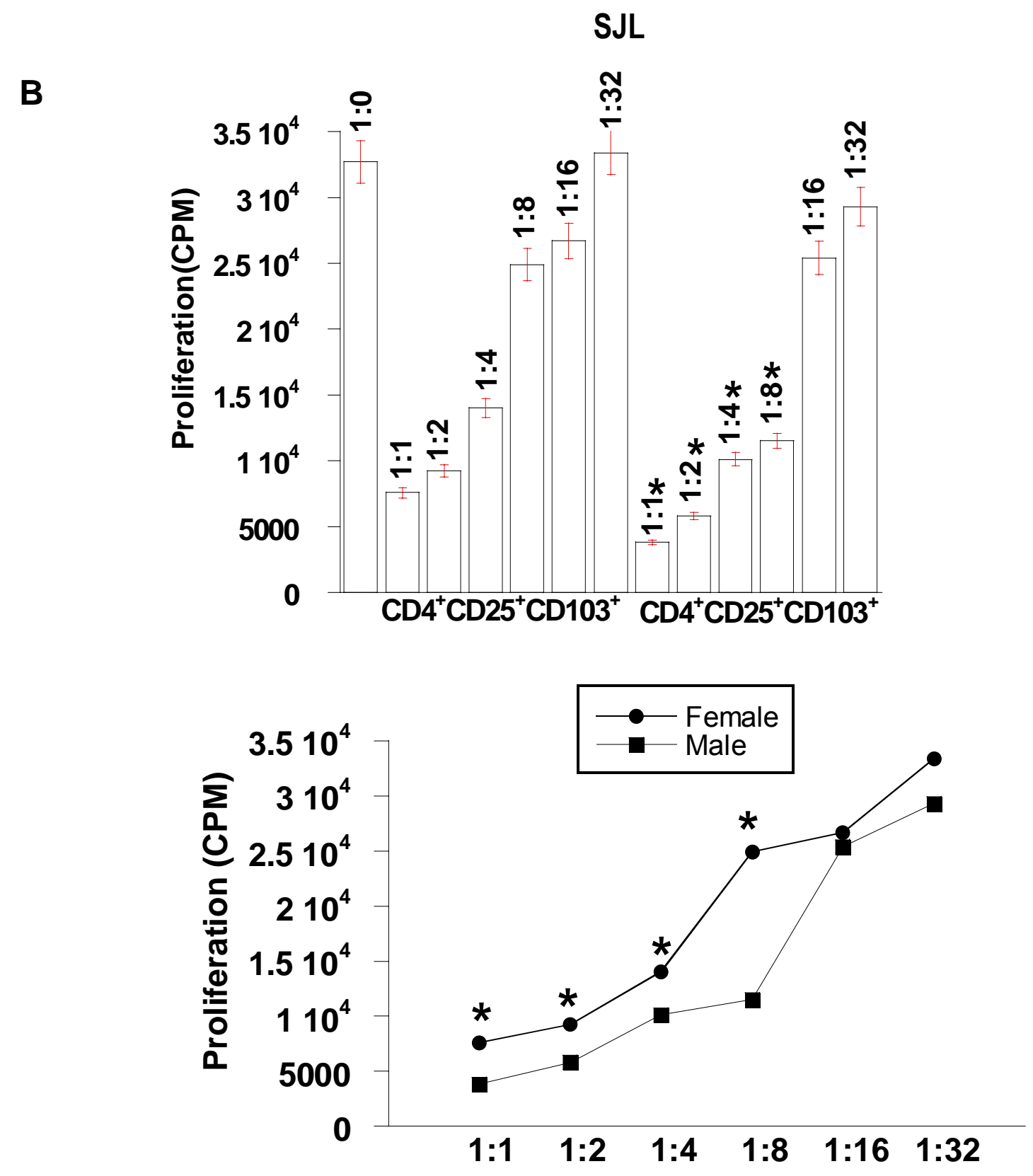


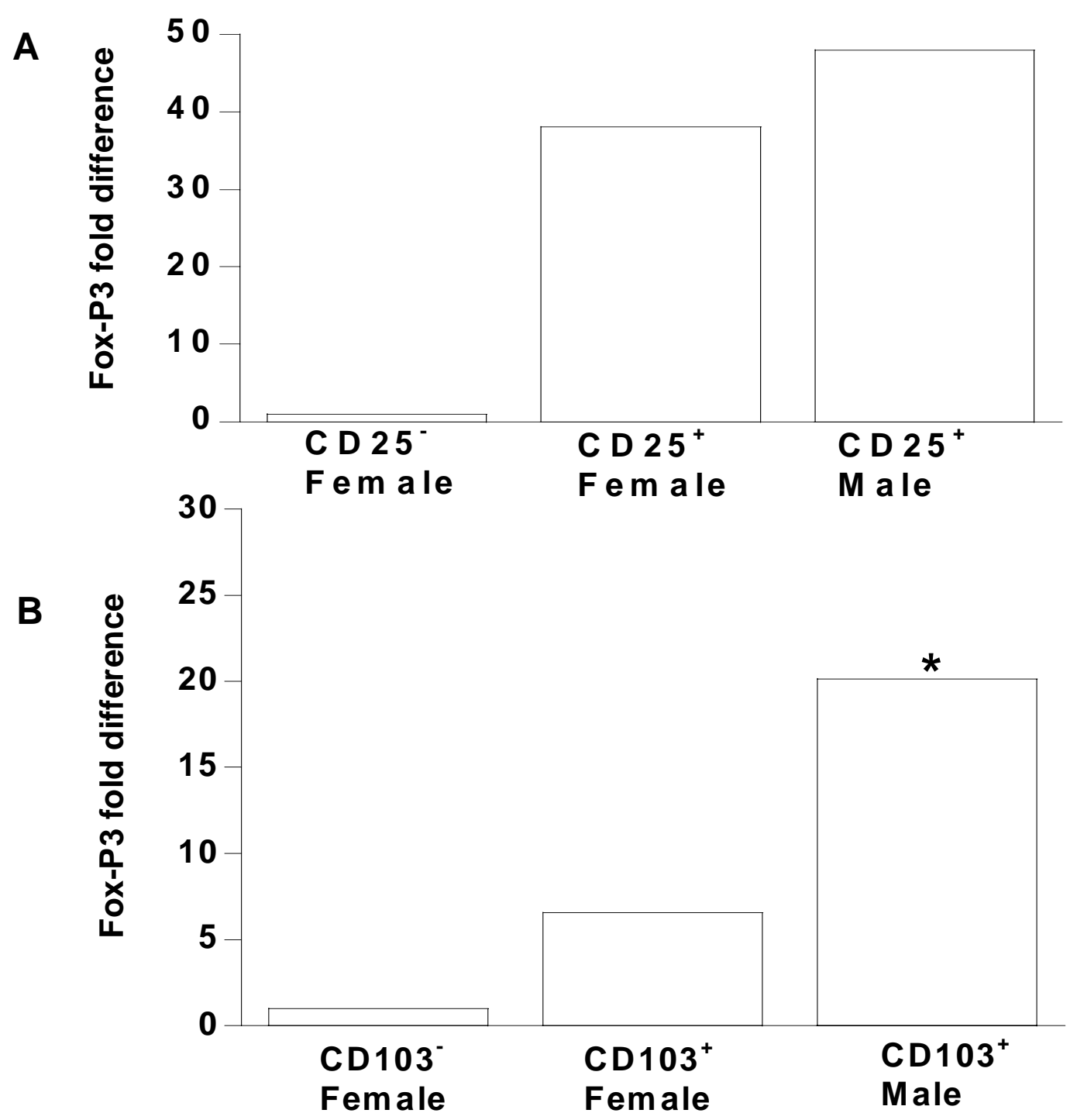

Figure 10. $\mathrm{CD}^{+} \mathrm{CD} 25^{+} \mathrm{CD} 103^{+}$, but not $\mathrm{CD} 4^{+} \mathrm{CD} 25^{+}$cells, from males express significantly higher levels of Foxp3 compared with females. Foxp3 mRNA from $\mathrm{CD}^{+} \mathrm{CD} 25^{+}(\mathrm{A})$ and $\mathrm{CD} 4{ }^{+} \mathrm{CD} 25^{+} \mathrm{CD} 103^{+}(\mathrm{B})$ cells, harvested from female or male C57BL/6 mice were quantified by real-time PCR and analyzed for the fold difference in Foxp3 expression, normalized relative to GAPDH mRNA expression. An * indicates a significant difference at $p<0.05$ between female and male expression of Foxp3. 
A $\quad$ C57BL/6

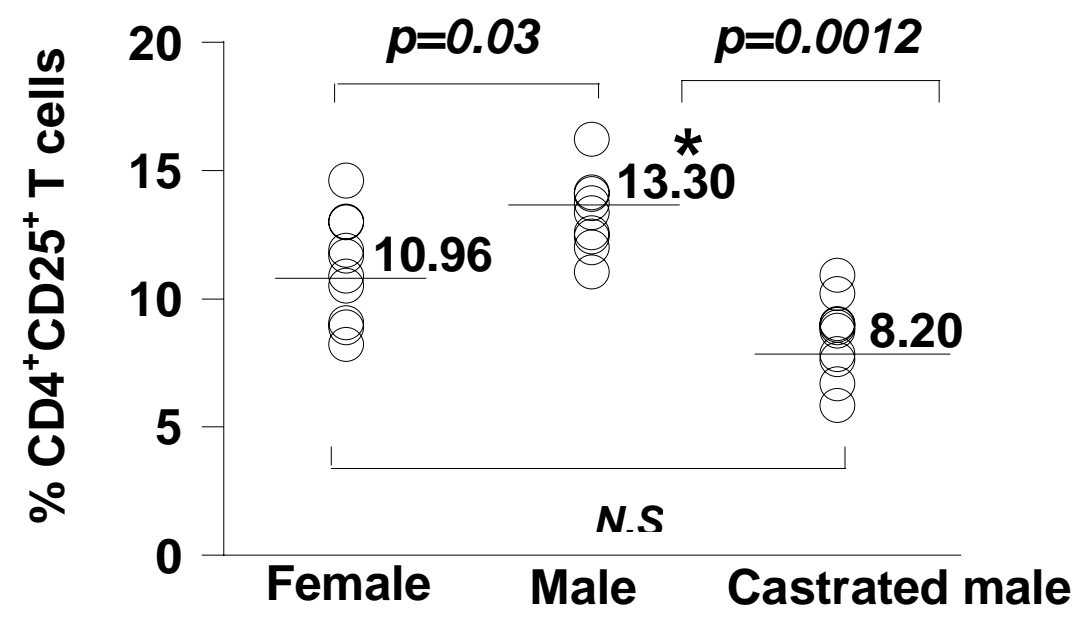

SJL

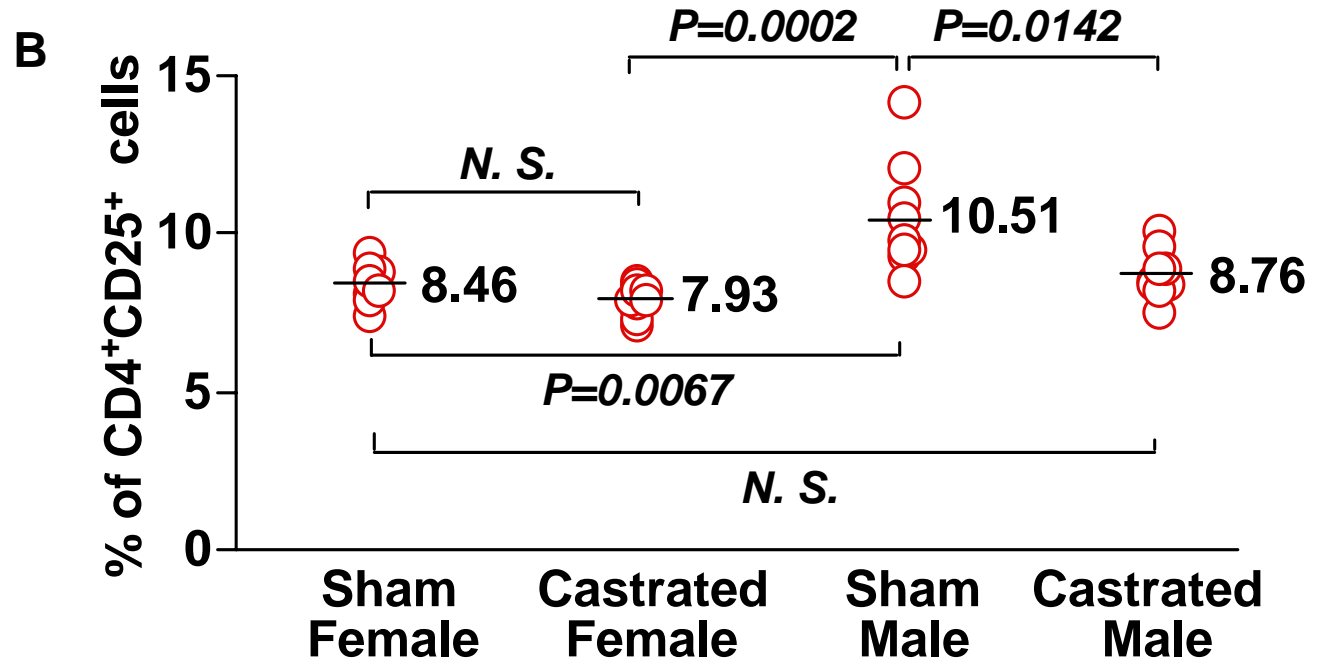

Figure 11. Castration in $\mathrm{C} 57 \mathrm{BL} / 6$ and $\mathrm{SJL}$ males decreases the percentage of $\mathrm{CD} 4^{+} \mathrm{CD} 25^{+} \mathrm{T}$ cells to levels comparable to those found in females. Pre-pubertal female or male mice were either sham castrated or castrated and the percentage of $\mathrm{CD} 4{ }^{+} \mathrm{CD} 25^{+}$cells determined at adulthood. Lymph nodes from individual mice were collected, and cells labeled with anti-CD4 and anti-CD25 antibodies, then analyzed by FACS ${ }^{\circledR}$. The percentage of $\mathrm{CD} 4^{+} \mathrm{CD} 25^{+} \mathrm{T}$ cells in castrated male C57BL/6 (A) or castrated female and male SJL (B) mice was determined. 

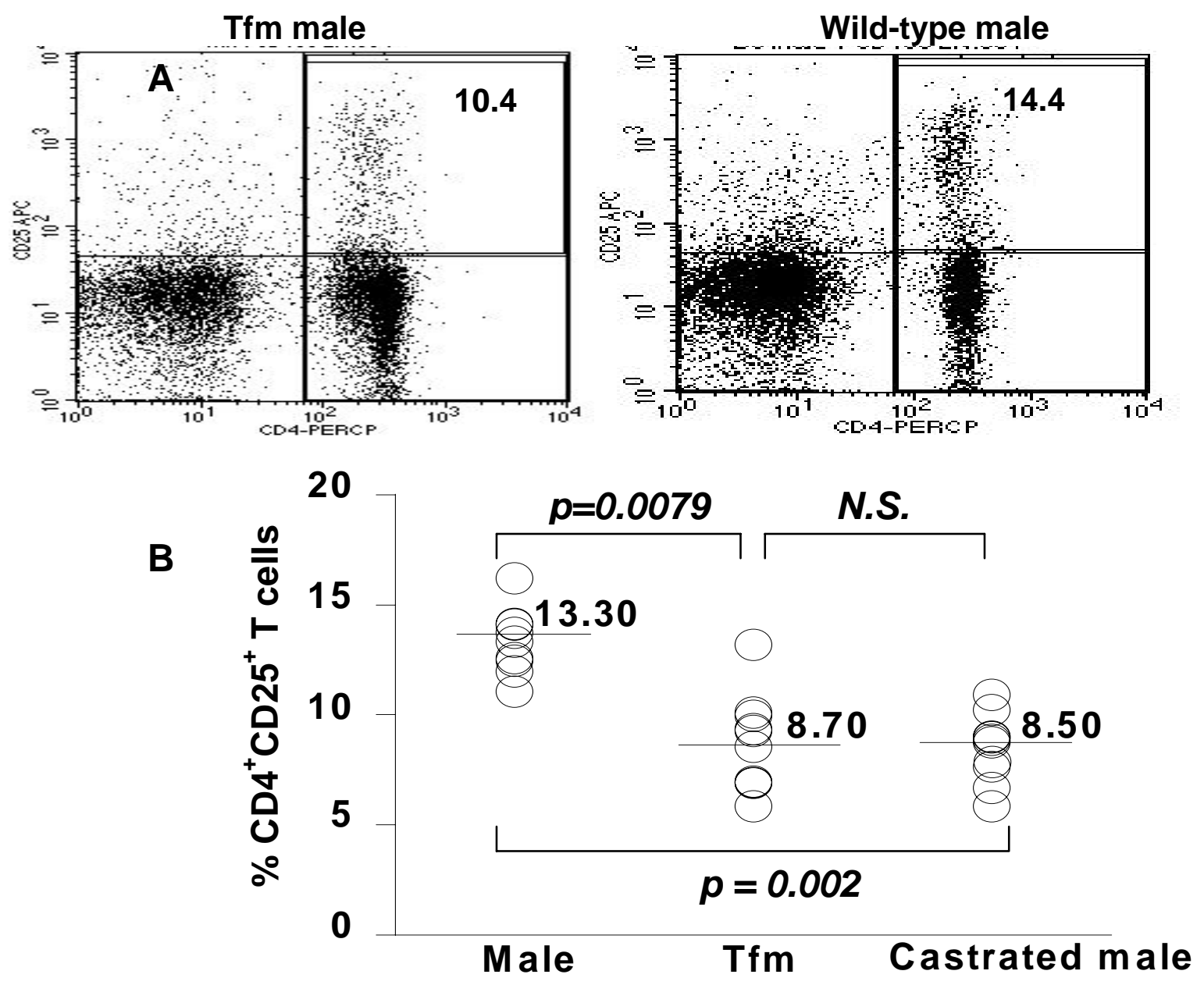

Figure 12. Testicular feminization mice (Tfm) have a lower percentage of $\mathrm{CD} 4^{+} \mathrm{CD} 25^{+}$ cells compared with wild-type male mice. Individual lymph node cells from adult Tfm, castrated or intact wild-type C57BL/6 male mice were collected, and labeled with anti-CD4 and anti-CD25 antibodies, then analyzed by FACS ${ }^{\circledR}$. Stained CD4 ${ }^{+}$T cells were gated and analyzed for the expression of the CD25 surface marker (A). An * indicates a significant difference at $\mathrm{p}<0.05$. 


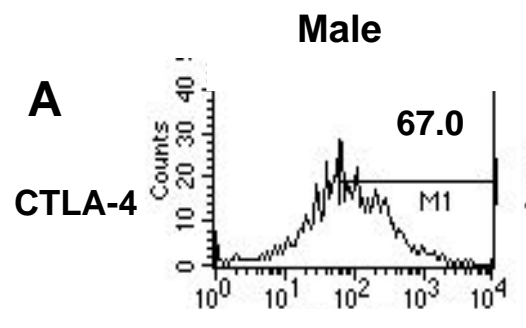

Female

Castrated male Tfm male
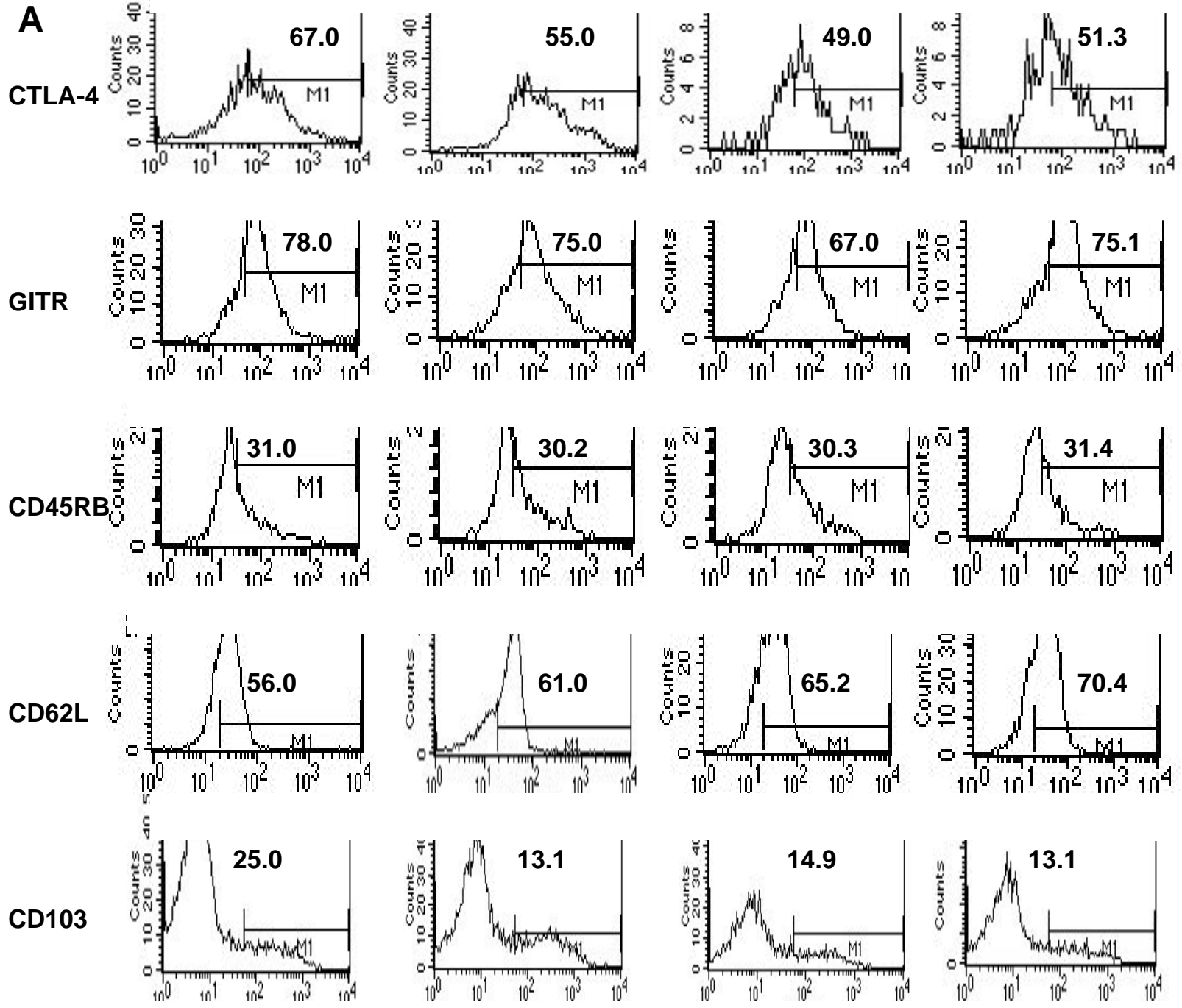

Figure 13. $\mathrm{CD} 4{ }^{+} \mathrm{CD} 25^{+}$cells from intact wild-type male mice express significantly more CD103, but not CD62L, CTLA-4, GITR or CD45RB compared with wild-type female, or castrated or Tfm male mice. One million lymph node cells from adult wild-type female, intact wild-type male or castrated or Tfm male mice were labeled with anti-CD4, anti-CD25 and anti-CD62L, CTLA-4, GITR, CD45RB, or CD103 antibodies and analyzed by FACS ${ }^{\circledR}$. Stained $\mathrm{CD} 4{ }^{+} \mathrm{CD} 25^{+} \mathrm{T}$ cells were gated and analyzed for the expression of these surface markers (A). The percentage of $\mathrm{CD} 4{ }^{+} \mathrm{CD} 25^{+} \mathrm{T}$ cells that expressed CD103, CD62L, CTLA-4, GITR or CD45RB (B) was determined. An * indicates a significant difference at $\mathrm{p}<0.05$. 

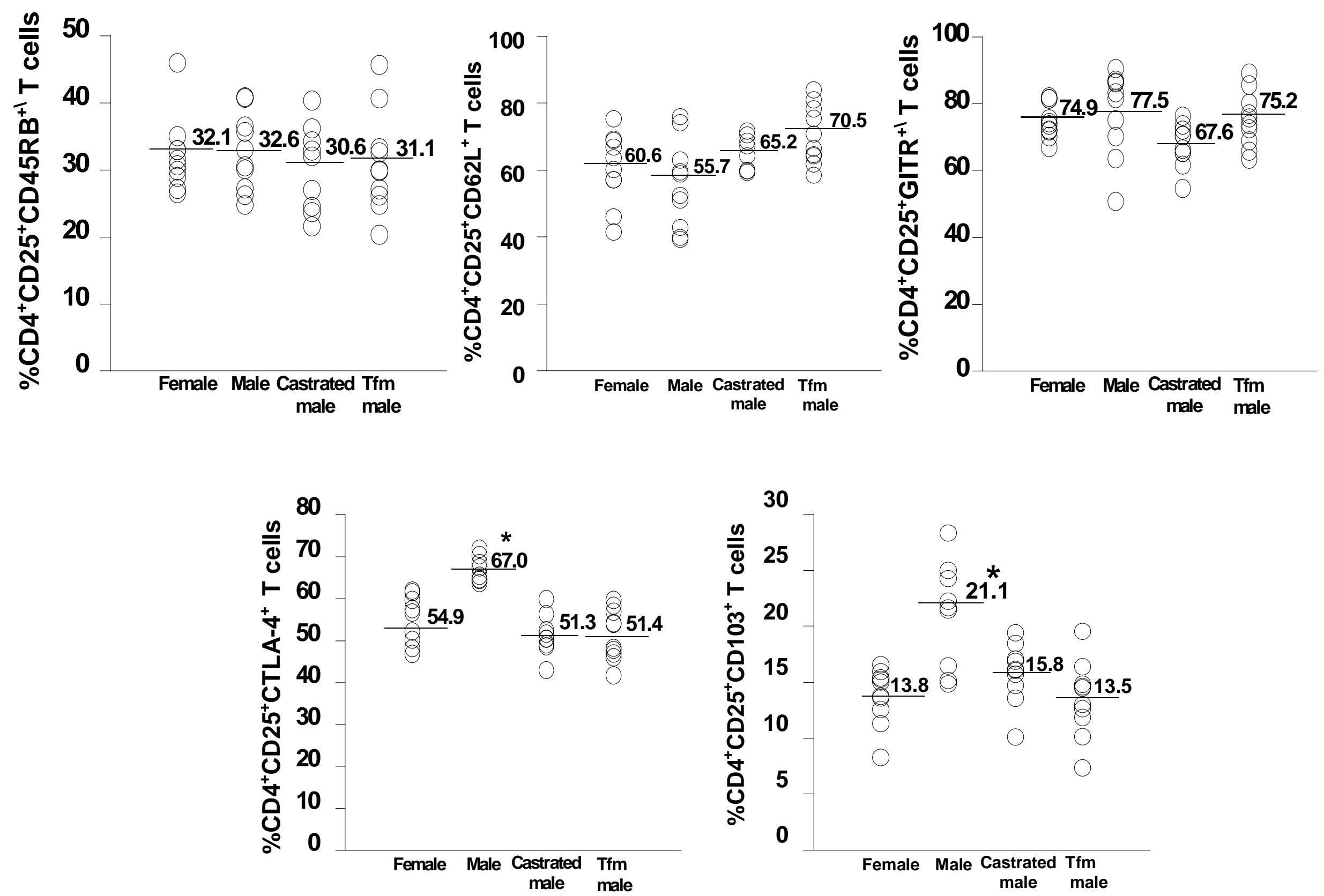

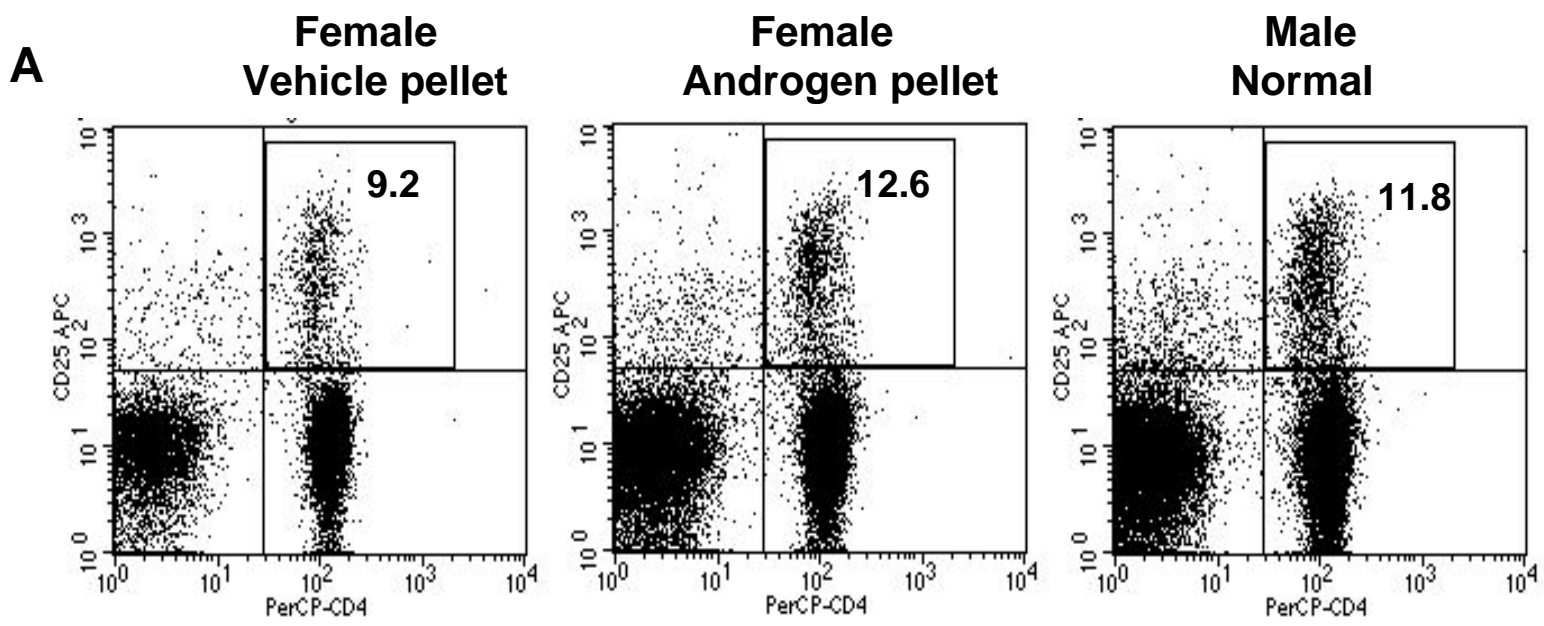

B

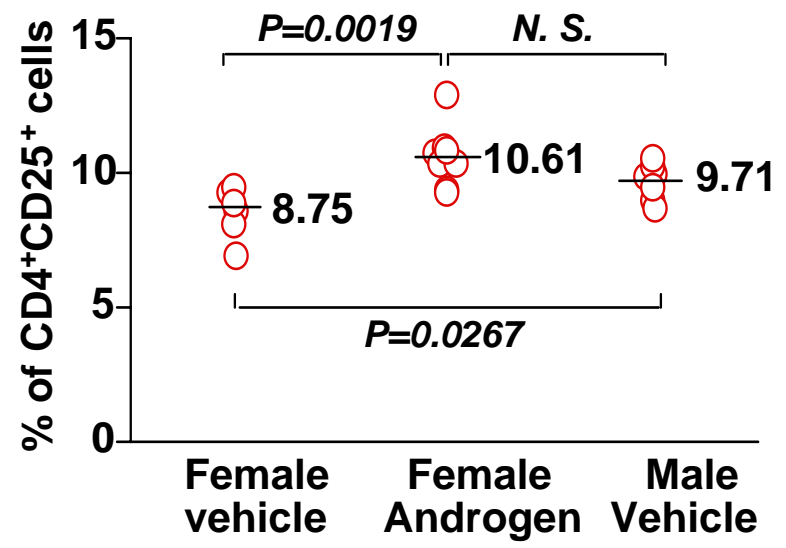

Figure 14. Androgens increase the percentage of $\mathrm{CD} 4{ }^{+} \mathrm{CD} 25^{+}$regulatory T cells in females. Sixty-day testosterone (DHT) release pellets or vehicle (control) pellets were ' implanted subcutaneously into the backs of female pre-pubertal C57BL/6 mice that were then euthanized 4-6 weeks later. Stained $\mathrm{CD}^{+} \mathrm{T}$ cells from normal male or female mice implanted with DHT or vehicle release pellets were gated and analyzed for the expression of $\mathrm{CD} 25$ (A). The percentages of $\mathrm{CD} 4{ }^{+} \mathrm{CD} 25^{+}$in female mice implanted with DHT or vehicle release pellets were compared to those from male mice (B). 


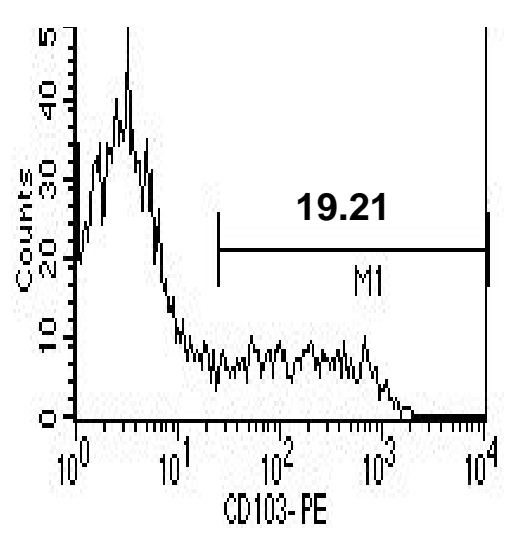

Female Normal

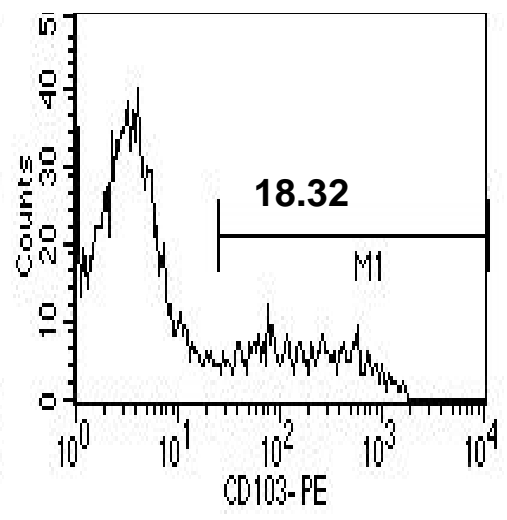

Female Vehicle

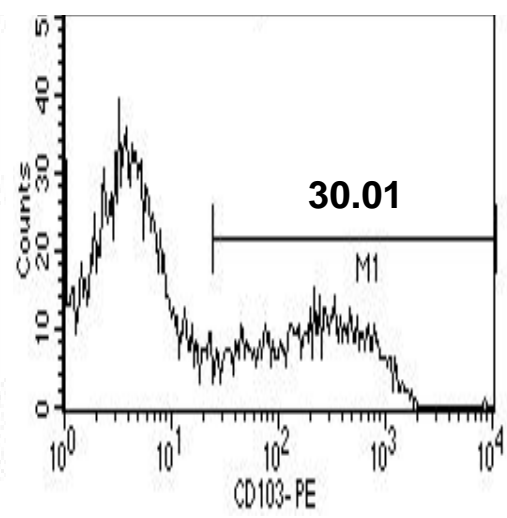

Female Androgen

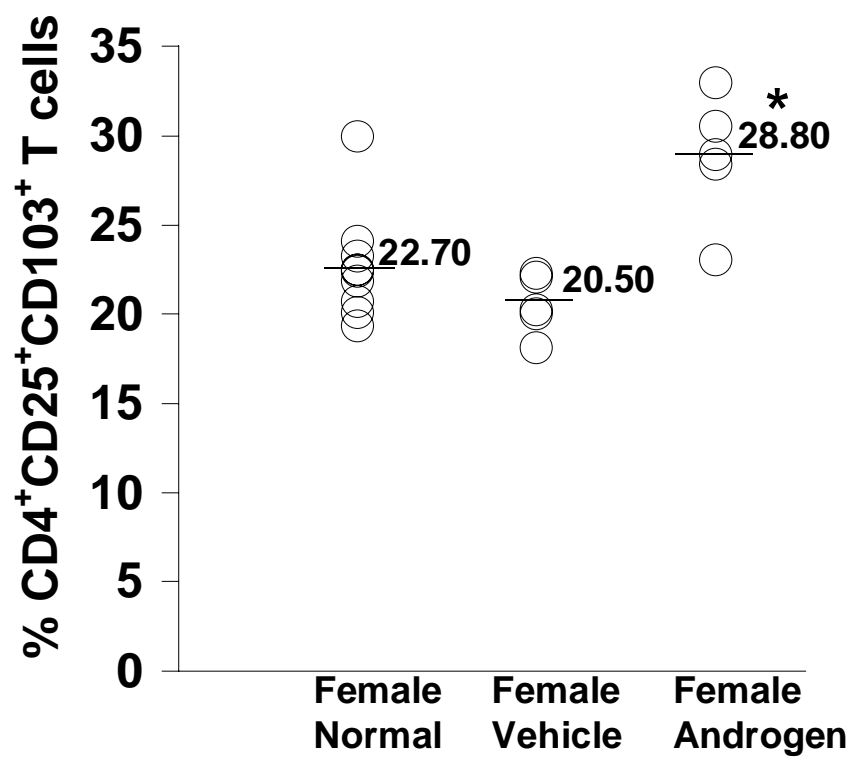

Figure 15. Treatment with androgens results in an increase in the percentage of $\mathrm{CD} 4^{+} \mathrm{CD} 25^{+} \mathrm{CD} 103^{+}$regulatory $\mathrm{T}$ cells in females. Sixty-day testosterone (DHT) release pellets or vehicle (control) pellets were implanted subcutaneously into the backs of female pre-pubertal C57BL/6 mice that were then euthanized 4-6 weeks later. Stained $\mathrm{CD} 4^{+} \mathrm{CD} 25^{+} \mathrm{T}$ cells from normal female or female mice implanted with DHT or vehicle release pellets were gated and analyzed for the expression of CD103 (A).

The percentages of $\mathrm{CD} 4^{+} \mathrm{CD} 25^{+} \mathrm{CD} 103^{+}$in female mice implanted with DHT or vehicle release pellets were compared to those from normal female mice (B). An * indicates a significant difference at $\mathrm{p}<0.05$. 
A
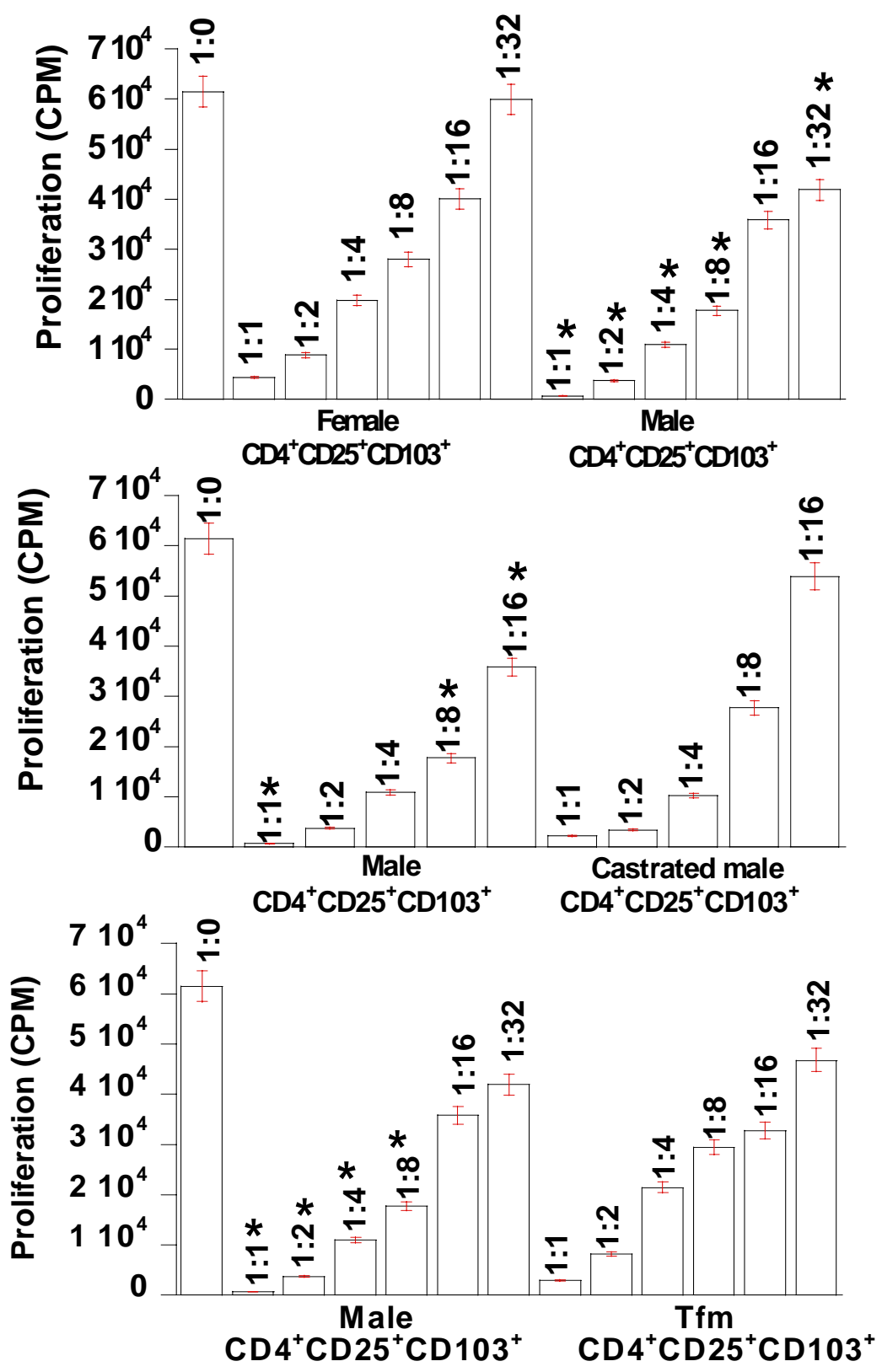

Figure 16. Intact $\mathrm{C} 57 \mathrm{BL} / 6$ male $\mathrm{CD} 4^{+} \mathrm{CD} 25^{+} \mathrm{CD} 103^{+}$cells suppress significantly better than intact female, or castrated or Tfm male $\mathrm{CD} 4^{+} \mathrm{CD} 25^{+} \mathrm{CD} 103^{+}$cells. Intact female or male, or castrated or Tfm male $\mathrm{CD} 4^{+} \mathrm{CD} 25^{+} \mathrm{CD} 103^{+}$cells were harvested from adult mice, and cocultured with male $\mathrm{CD} 4^{+} \mathrm{CD} 25^{-}$responder $\mathrm{T}$ cells in the presence of male irradiated spleen cells (APC) and anti-CD3 antibody. $\mathrm{CD} 4{ }^{+} \mathrm{CD} 25^{+} \mathrm{CD} 103^{+}$regulatory $\mathrm{T}$ cell function was tested at various responder : regulatory cell ratios. An * indicates a significant difference at $\mathrm{p}$ $<0.05$. 


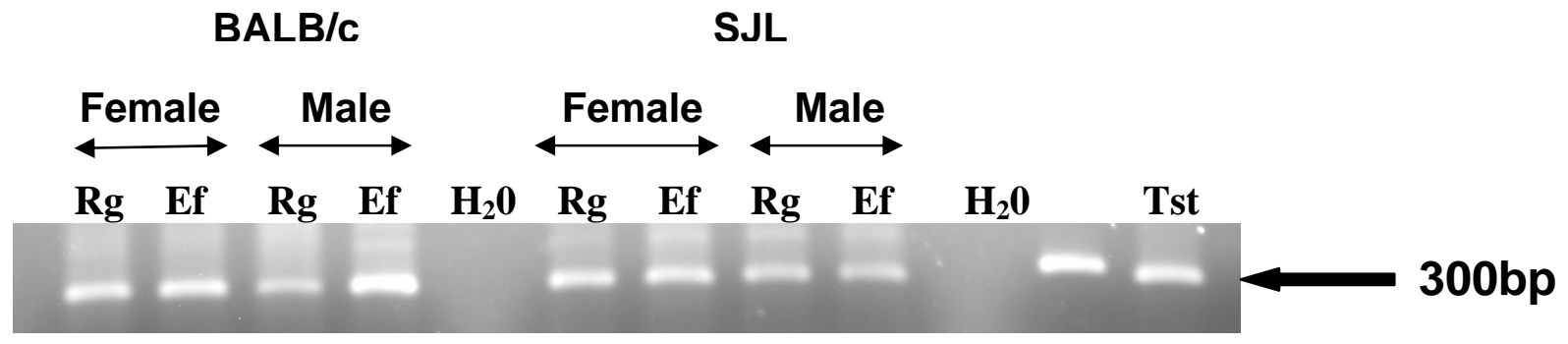

Figure 17. Androgen receptor mRNA is expressed by both $\mathrm{CD} 4{ }^{+} \mathrm{CD} 25^{+}$and $\mathrm{CD} 4^{+} \mathrm{CD} 25^{-} \mathrm{T}$ cells. $\mathrm{CD} 4^{+} \mathrm{CD} 25^{+}$and $\mathrm{CD} 4^{+} \mathrm{CD} 25^{-} \mathrm{T}$ cells from female and male adult mice were sorted to $>98 \%$ purity, mRNA extracted and the androgen receptor mRNA detected by RT-PCR. mRNA from mouse testes was used as positive control. $\mathrm{Rg}=$ regulatory cells, $\mathrm{Ef}=$ effector cells, $\mathrm{Tst}=$ testes 

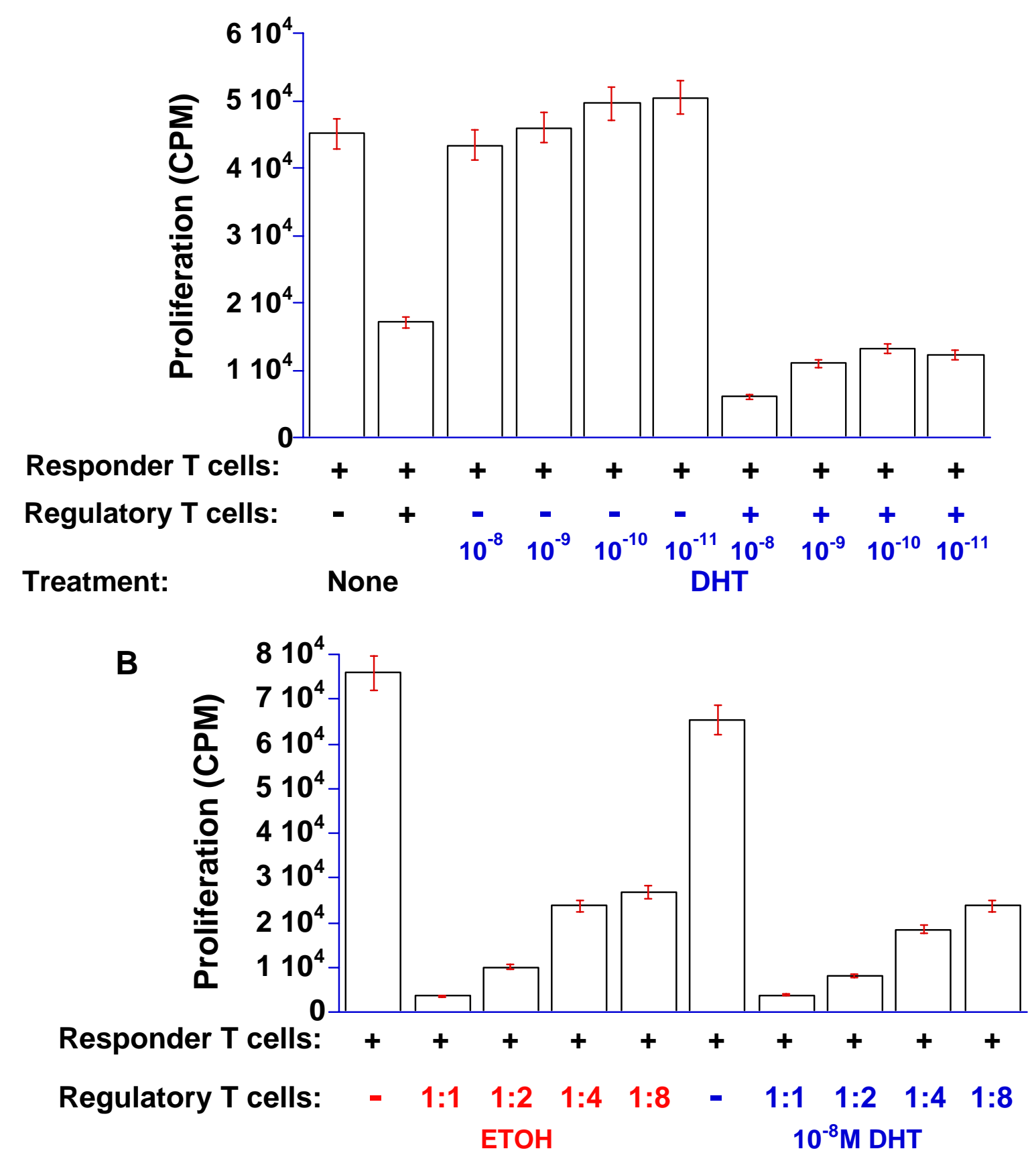

Figure 18. Treatment of $\mathrm{CD} 4{ }^{+} \mathrm{CD} 25^{+}$cells with androgens in vitro does not affect their regulatory function. A constant number of $\mathrm{CD} 4^{+} \mathrm{CD} 25^{+} \mathrm{T}$ cells was co-cultured with $\mathrm{CD} 4^{+} \mathrm{CD} 25^{-} \mathrm{T}$ cells in the presence of irradiated spleen cells (APC), anti-CD3 and increasing doses of DHT (A), or using the highest dose of DHT $\left(10^{-8}\right)$ and varying ratios of $\mathrm{CD} 4^{+} \mathrm{CD} 25^{+}$ regulatory cells (B). 


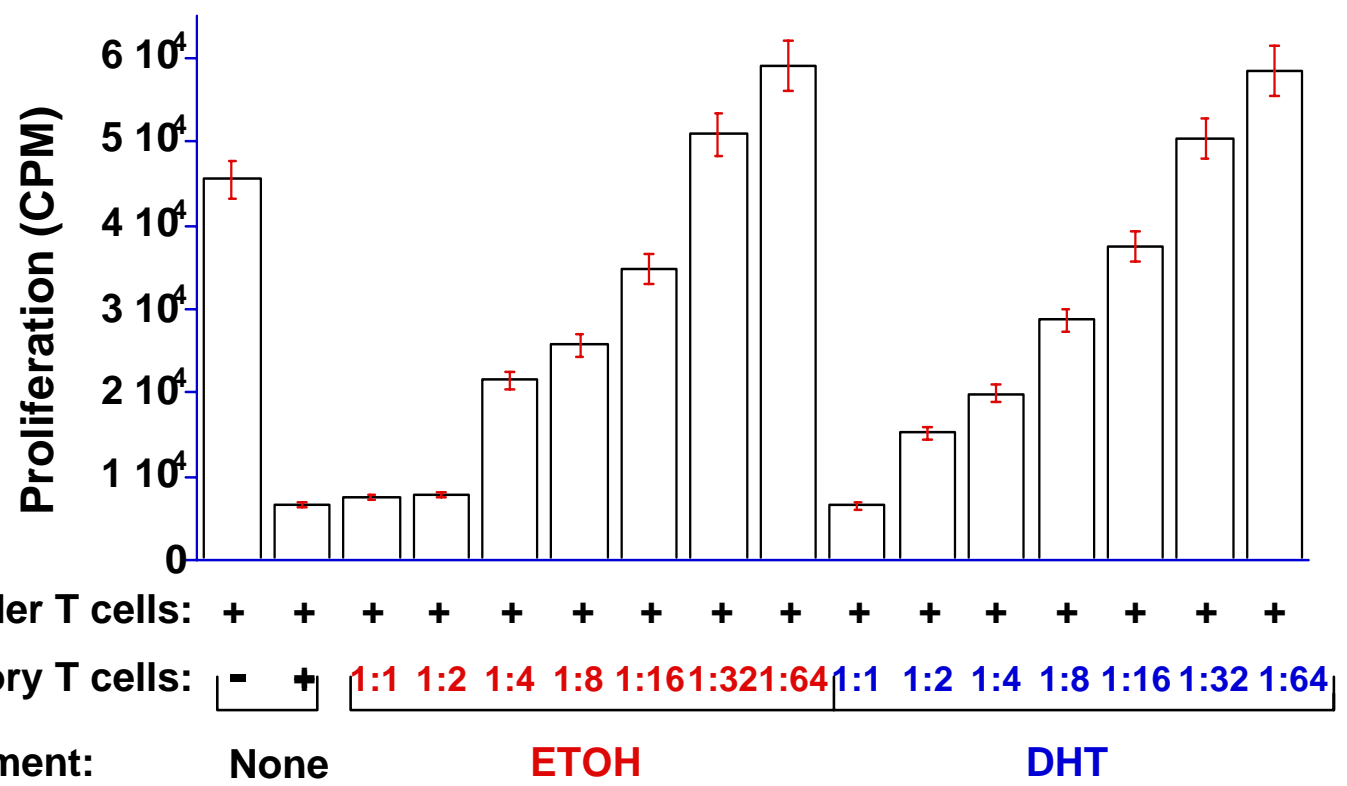

Figure 19. Pretreatment of $\mathrm{CD} 4{ }^{+} \mathrm{CD} 25^{+}$with androgens has no direct effect on regulatory function of $\mathrm{CD} 4^{+} \mathrm{CD} 25^{+}$cells. $\mathrm{CFSE}^{+} \mathrm{CD} 4^{+} \mathrm{CD} 25^{+} \mathrm{T}$ cells were co-cultured overnight in the presence of irradiated spleen cells (APC), antiCD3 and $10^{-8} \mathrm{M}$ DHT (Sigma Aldrich, USA). At the end of the culture period, the $\mathrm{CFSE}^{+} \mathrm{CD} 4^{+} \mathrm{CD} 25^{+}$DHTtreated regulatory $\mathrm{T}$ cells were sorted from the APC and varying numbers co-cultured with fresh untreated $\mathrm{CD} 4^{+} \mathrm{CD} 25^{-}$cells, APC and anti-CD3. 


\section{3-Week-old}

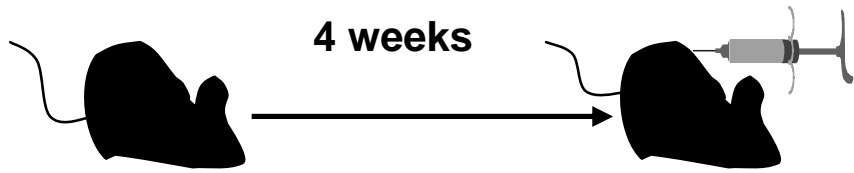

Castrate male B6.SJL-ptprca $\left(\right.$ CD45.1 $\left.1^{+}\right)$mice

Implant testosterone or vehicle release pellets

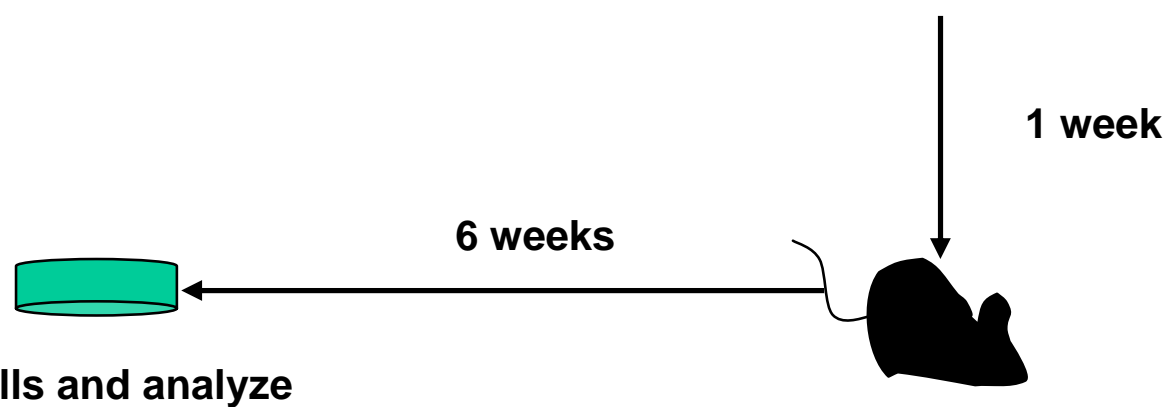

Collect cells and analyze CD4 ${ }^{+} \mathrm{CD} 25^{+} \mathrm{CD} 45.2^{+}$regulatory $\mathrm{T}$ cells by FACS ${ }^{\circledR}$ or sort and test for their in vitrn reculatorv function

Sublethally irradiate mice and transfer bone marrow stem cells from $\mathrm{Tfm}$ or $\mathrm{B} 6$

Figure 20. Protocol to test for the influence of androgens on numbers, phenotype and/or function of $\mathrm{CD} 4{ }^{+} \mathrm{CD} 25^{+}$cells through an effect on bone-marrow derived cells. 


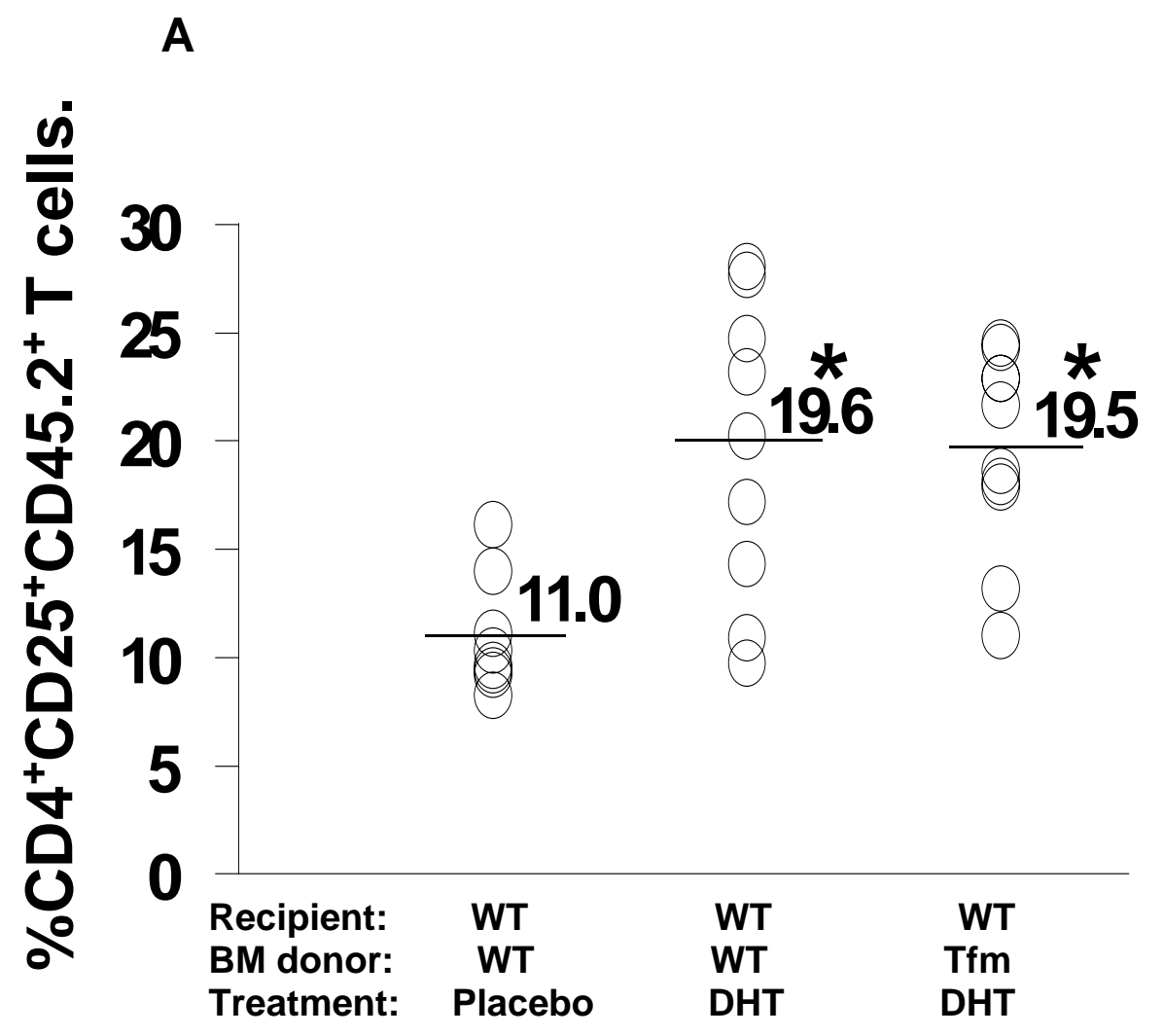

Figure 21. Androgens influence the function but not the percentage of $\mathrm{CD} 4{ }^{+} \mathrm{CD} 25^{+}$cells through an effect on bone marrow-derived cells. Bone marrow stem cells (hematopoietic cells) from $\mathrm{Tfm}$ (androgen receptor deficient) or wildtype C57BL/6 mice (CD45.2 ${ }^{\dagger}$ ) were sorted and transferred into castrated dihydrotestosterone (DHT) or placebo-treated B6.SJL-ptprca $\left(\mathrm{CD} 45.1^{+}\right)$mice. The mice were then euthanized 6 weeks after bone marrow transfer. Cells were collected from lymphoid organs and the CD45 isotype $\left(\mathrm{CD} 45.2^{+}\right)$was used as a marker to track transferred cells. The percentage of CD45. $2^{+} \mathrm{CD}^{+} \mathrm{CD} 25^{+} \mathrm{T}$ cells was determined by $\mathrm{FACS}^{\circledR}(\mathrm{A})$, or alternatively, these cells were sorted for $\mathrm{CD} 45.2^{+} \mathrm{CD} 4^{+} \mathrm{CD} 25^{+}$cells and analyzed for regulatory $\mathrm{T}$ cell function in vitro (B). An * indicates a significant difference at $\mathrm{p}<0.05 . \mathrm{WT}=$ wildtype, $\mathrm{BM}=$ bone marrow, DHT =dihydrotestosterone. 
B

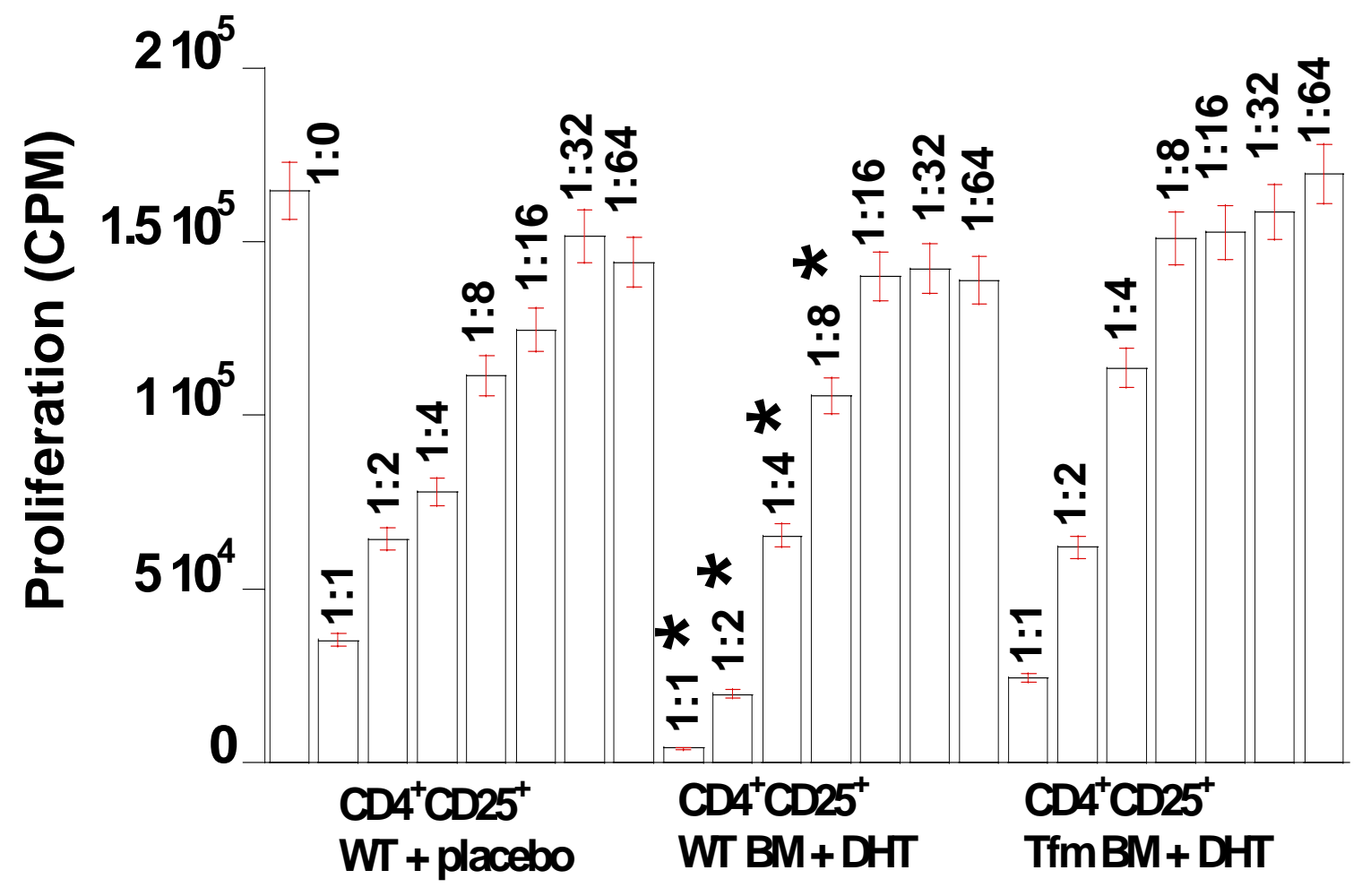


3-Week-old

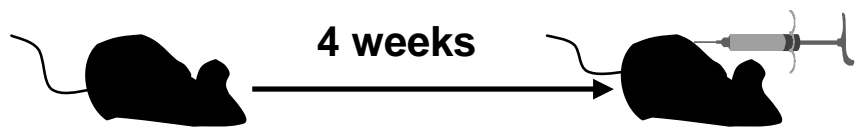

Normal B6 and Tfm (CD45.2 ${ }^{+}$Implant testosterone or male mice.

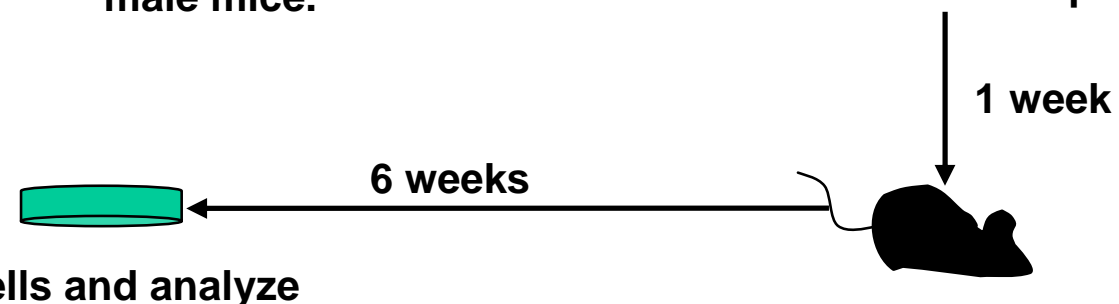

Collect cells and analyze CD4 ${ }^{+}$CD25 ${ }^{+}$CD45.1 $1^{+}$or $\mathrm{CD}^{+} 5^{+} \mathrm{CD} 45.1^{+} \mathrm{CD}_{103^{+}}$

Sublethally irradiate and regulatory $\mathrm{T}$ cells by $\mathrm{FACS}^{\circledR}$ transfer bone marrow stem cells from B6.SJL-ptprca $\left(\right.$ CD45.1 $1^{+}$mice.

Figure 22. Protocol to test for the influence of androgens on the numbers and phenotype of $\mathrm{CD} 4{ }^{+} \mathrm{CD} 25^{+}$cells through an effect on the non-bone marrow-derived compartment. 
A

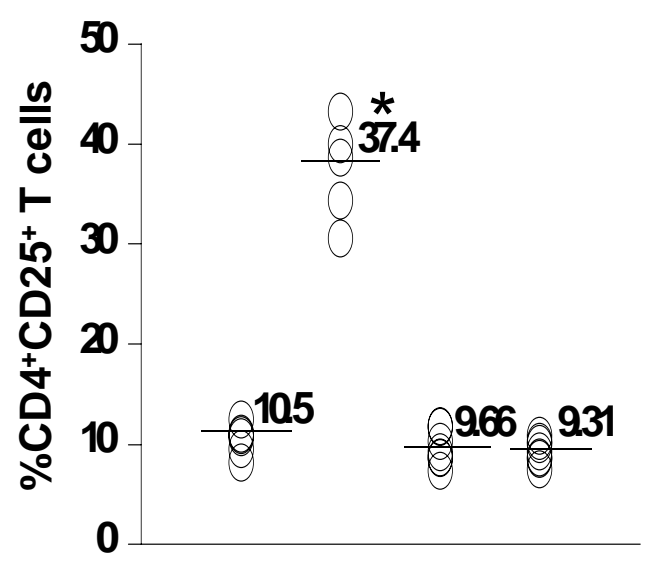

Recipient: WT WT Tfm Tfm

BM donor: WT WT WT WT Treatment: PLA DHT DHT DHT
B

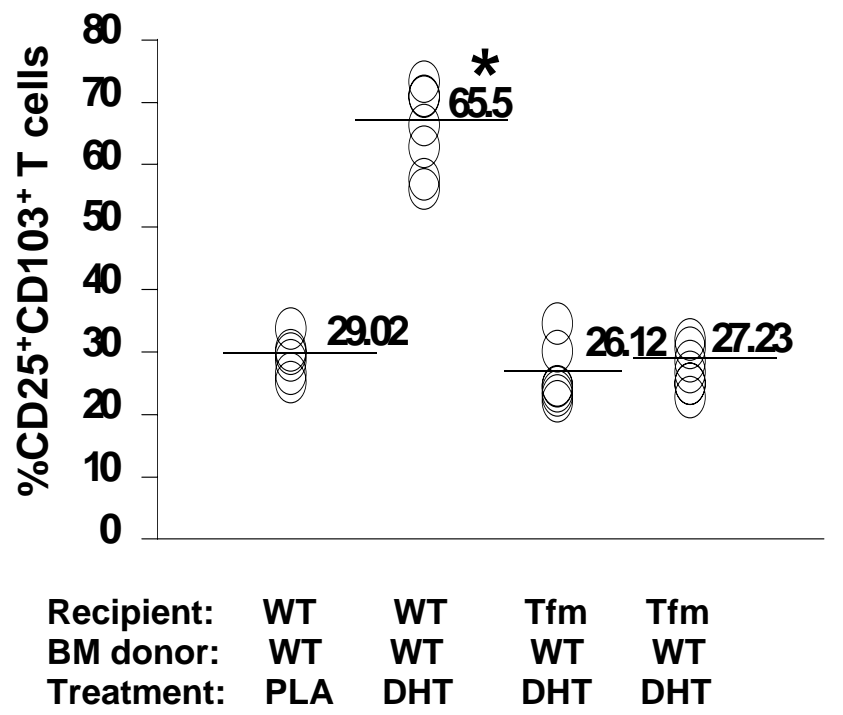

Figure 23. Androgens influence the percentages of $\mathrm{CD} 4^{+} \mathrm{CD} 25^{+}$and $\mathrm{CD} 4^{+} \mathrm{CD} 25^{+} \mathrm{CD} 103^{+}$cells through an effect on the non-bone marrow-derived compartment. T cell-depleted bone marrow cells (hematopoietic cells) from male B6.SJL-ptprca (CD45. $\left.1^{+}\right)$mice were sorted and transferred into placebo or DHT-treated, $\mathrm{Tfm}$ (androgen receptor deficient) or wildtype C57BL/6 mice (CD45.2 $\left.{ }^{+}\right)$. Mice were then euthanized 6 weeks after bone marrow transfer. Cells were collected from lymphoid organs and the CD45 isotype (CD45.1 $\left.1^{\dagger}\right)$ was used as a marker to track transferred cells. The percentage of $\mathrm{CD} 4{ }^{+} \mathrm{CD} 25^{+} \mathrm{CD} 45.1^{+}$(A) or $\mathrm{CD} 25^{+} \mathrm{CD} 45.1^{+} \mathrm{CD} 103^{+}$(B) $\mathrm{T}$ cells was determined by FACS ${ }^{\circledR}$. An $*$ indicates a significant difference at $\mathrm{p}<0.05$. WT $=$ wildtype, $\mathrm{BM}=$ bone marrow, $\mathrm{PLA}=$ placebo, $\mathrm{DHT}=$ Dihydrotestosterone 
Implant fetal thymus from

3-week-old

B6 control or Tfm mice.

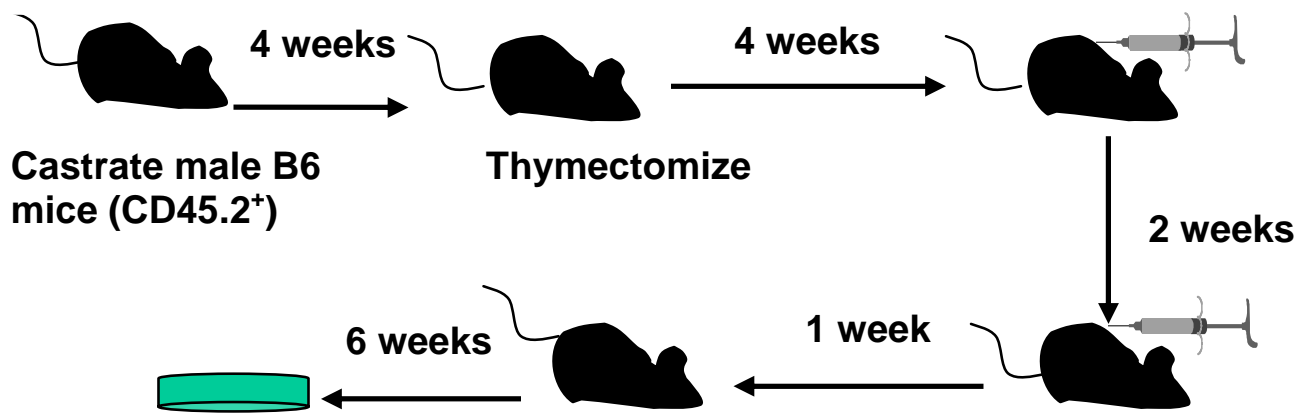

Collect cells and analyze CD4 ${ }^{+}$CD25 ${ }^{+}$CD45.1 ${ }^{+}$ or $\mathrm{CD} 25^{+} \mathrm{CD} 45.1^{+} \mathrm{CD} 103^{+}$ regulatory $T$ cells by FACS ${ }^{\circledR}$

Implant testosterone or vehicle release pellets

Figure 24. Protocol to test for the influence of androgens on the numbers and phenotype of $\mathrm{CD} 4{ }^{+} \mathrm{CD} 25^{+}$cells through an effect on the thymus. 
A

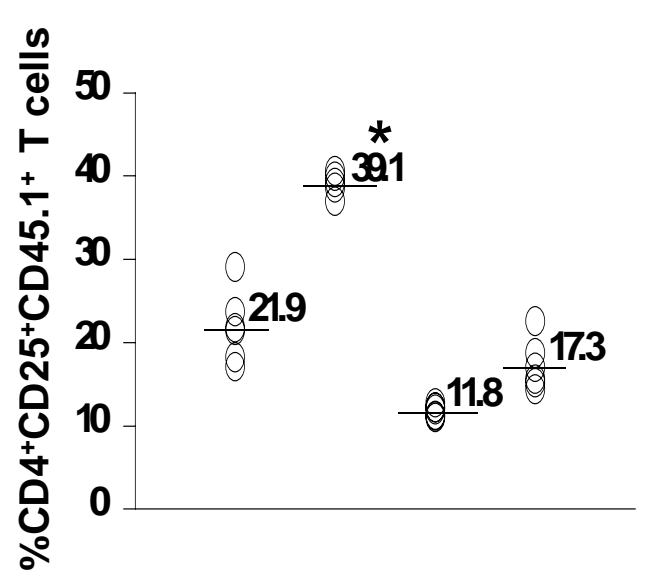

B

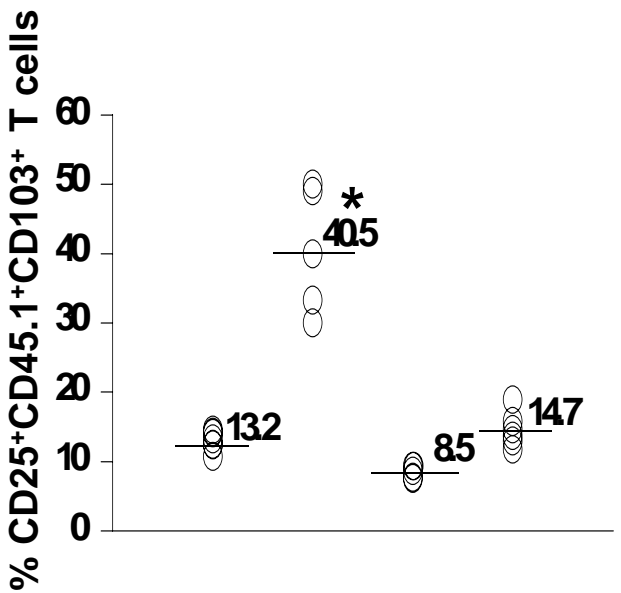

$\begin{array}{llllllllll}\text { Recipient: } & \text { WT } & \text { WT } & \text { WT } & \text { WT } & \text { Recipient: } & \text { WT } & \text { WT } & \text { WT } & \text { WT } \\ \text { BM donor: } & \text { WT } & \text { WT } & \text { WT } & \text { WT } & \text { BM donor: } & \text { WT } & \text { WT } & \text { WT } & \text { WT } \\ \text { Thymic T : } & \text { WT } & \text { WT } & \text { Tfm } & \text { Tfm } & \text { Thymic T: } & \text { WT } & \text { WT } & \text { Tfm } & \text { Tfm } \\ \text { Treatment: } & \text { PLA } & \text { DHT } & \text { PLA } & \text { DHT } & \text { Treatment: } & \text { PLA } & \text { DHT } & \text { PLA } & \text { DHT }\end{array}$

Figure 25. Androgens influence the percentages of $\mathrm{CD} 4^{+} \mathrm{CD} 25^{+}$and $\mathrm{CD} 4^{+} \mathrm{CD} 25^{+} \mathrm{CD} 103^{+}$ cells through an effect on the thymus. T cell-depleted bone marrow cells (hematopoietic cells) from male B6.SJL-ptprca $\left(\mathrm{CD} 45.1^{+}\right)$mice were sorted and transferred into placebo or DHT-treated wild-type C57BL/6 mice that had been castrated and thymectomized and implanted with Tfm or wildtype C57BL/6 (CD45. $\left.2^{+}\right)$donor thymus. Mice were then euthanized 6 weeks after bone marrow transfer. Cells were collected from lymphoid organs and the CD45 isotype (CD45.1 $\left.1^{+}\right)$was used as a marker to track transferred cells. The percentage of $\mathrm{CD} 4{ }^{+} \mathrm{CD} 25^{+} \mathrm{CD} 45.1^{+}(\mathrm{A})$ or $\mathrm{CD} 25^{+} \mathrm{CD} 45.1^{+} \mathrm{CD} 103^{+}$(B) $\mathrm{T}$ cells was determined by $\mathrm{FACS}^{\circledR}$. An * indicates a significant difference at $\mathrm{p}<0.05$. $\mathrm{WT}=$ wildtype, $\mathrm{BM}=$ bone marrow, $\mathrm{T}=$ transplant, $\mathrm{PLA}=$ placebo, DHT $=$ Dihydrotestosterone 
Table 1. Female/Male Ratios in Autoimmune Diseases

\begin{tabular}{ll}
\hline Autoimmune disease & Female to male ratio \\
\hline Hashimoto's disease & 50 -to-1 \\
Sjogren's syndrome & 9 -to-1 \\
Systemic lupus erythematosus & 9-to-1 \\
Antiphospholipid syndrome & 9-to-1 \\
Primary biliary cirrhosis & 9-to-1 \\
Mixed connective tissue disease & 8-to-1 \\
Chronic active hepatitis & 8-to-1 \\
Graves' disease & 7-to-1 \\
Rheumatoid arthritis & 4-to-1 \\
Scleroderma & 3-to-1 \\
Chronic idiopathic thrombocytopenic purpura & 2-to-1 \\
Multiple sclerosis & 4 -to-1 \\
\hline
\end{tabular}

From the American Autoimmune Related Diseases Association, Michigan National Bank Building, 15475 Granot Ave, Detroit, MI 48205, (313) 371-8600. http://www.womenshealth.gov/OWH/pub/autoimmune/index.htm 
Table 2. Analysis of the percentage of $\mathrm{CD}^{+} \mathrm{CD} 25^{+} \mathrm{T}$ cells in female and male mice.

\begin{tabular}{|c|c|c|c|c|c|c|c|c|c|c|c|c|c|c|}
\hline & \multicolumn{2}{|c|}{ Exp\#1 } & \multicolumn{2}{|c|}{ Exp\#2 } & \multicolumn{2}{|c|}{ Exp\#3 } & \multicolumn{2}{|c|}{ Exp\#4 } & \multicolumn{2}{|c|}{ Exp\#5 } & \multicolumn{2}{|c|}{ Exp\#6 } & \multicolumn{2}{|c|}{ Exp\#7 } \\
\hline & 9 & $\pi$ & $\uparrow$ & & $\uparrow$ & 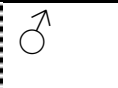 & $q$ & 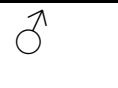 & $q$ & 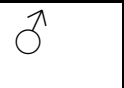 & 9 & 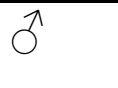 & 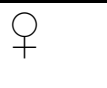 & 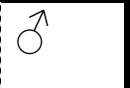 \\
\hline C57BL/6 & $\begin{array}{l}19.83 \pm \\
0.63(3) \\
(9 \text { wks) }\end{array}$ & $\begin{array}{l}26.40^{*} \pm \\
0.63(3) \\
(9 \text { wks }) \\
{ }^{*} P<0.0001\end{array}$ & $\begin{array}{l}16.49 \pm \\
0.35(3) \\
(10 \mathrm{wks})\end{array}$ & $\begin{array}{l}20.58^{*} \pm \\
0.23(3) \\
(10 \text { wks } \\
{ }^{*} P=0.006\end{array}$ & $\begin{array}{l}10.96 \pm \\
0.65(10) \\
(9 \text { wks) }\end{array}$ & $\begin{array}{l}13.30 * \pm \\
0.50(9) \\
(9 \text { wks) } \\
{ }^{*} P=0.03\end{array}$ & $\begin{array}{l}12.89 \pm \\
0.60(5) \\
(10 \mathrm{wks})\end{array}$ & $\begin{array}{l}15.80^{*} \pm \\
0.97(5) \\
(10 \text { wks }) \\
{ }^{*} P=0.034\end{array}$ & $\begin{array}{l}13.10 \pm \\
0.23(10) \\
(9 \text { wks) }\end{array}$ & $\begin{array}{l}15.78^{*} \pm \\
0.51(10) \\
(9 \text { wks }) \\
{ }^{*} P=0.0001\end{array}$ & $\begin{array}{l}15.27 \pm \\
1.61(5) \\
(8 \text { wks) }\end{array}$ & $\begin{array}{l}14.66 \pm \\
1.19(5) \\
(8 \text { wks) } \\
P=0.765\end{array}$ & $\begin{array}{l}9.60 \pm \\
0.44(10) \\
(9 \text { wks) }\end{array}$ & $\begin{array}{l}11.60 \pm \\
0.55(10) \\
(9 \text { wks }) \\
P=0.063\end{array}$ \\
\hline BALB/C & $\begin{array}{l}16.78 \pm \\
0.95(6) \\
(10 \text { wks) }\end{array}$ & $\begin{array}{l}17.10 \pm \\
0.85(6) \\
(10 \text { wks }) \\
P=0.412\end{array}$ & $\begin{array}{l}12.00 \pm \\
1.39(5) \\
(12 \text { wks) }\end{array}$ & $\begin{array}{l}11.90 \pm \\
0.28(4) \\
(12 \text { wks) } \\
P=0.555\end{array}$ & $\begin{array}{l}9.70 \pm \\
0.48(5) \\
\text { (8 wks) }\end{array}$ & $\begin{array}{l}11.70 * \pm \\
0.40(8) \\
(8 \text { wks) } \\
{ }^{*} P=0.041\end{array}$ & & & & & & & & \\
\hline SJL & $\begin{array}{l}10.20 \pm \\
0.90(8) \\
(8 \text { wks) }\end{array}$ & $\begin{array}{l}11.36 \pm \\
0.78(10) \\
(8 \text { wks) } \\
P=0.081\end{array}$ & $\begin{array}{l}12.58 \pm \\
0.27(5) \\
(9 \text { wks) }\end{array}$ & $\begin{array}{l}15.93^{*} \pm \\
1.12(5) \\
(9 \text { wks }) \\
{ }^{*} P=0.035\end{array}$ & $\begin{array}{c}9.72 \pm \\
0.41(9) \\
(9 \text { wks) }\end{array}$ & $\begin{array}{c}10.70 \pm \\
0.32(9) \\
(9 \text { wks }) \\
P=0.312\end{array}$ & $\begin{array}{l}16.12 \pm \\
0.64(10) \\
(10 \text { wks) }\end{array}$ & $\begin{array}{l}16.98 \pm \\
0.54(9) \\
(10 \text { wks }) \\
P=0.786\end{array}$ & $\begin{array}{l}15.30 \pm \\
1.31(5) \\
(8 \mathrm{wks})\end{array}$ & $\begin{array}{l}24.18^{*} \pm \\
1.71(5) \\
(8 \text { wks) } \\
{ }^{*} P=0.003\end{array}$ & $\begin{array}{l}6.60 \pm \\
0.35(10) \\
(6 \text { wks) }\end{array}$ & $\begin{array}{l}11.45^{*} \pm \\
1.10(10) \\
(6 \text { wks) } \\
* P=0.005\end{array}$ & $\begin{array}{l}7.56 \pm \\
0.23(10) \\
(5 \text { wks) }\end{array}$ & $\begin{array}{l}10.30^{*} \pm \\
0.34(10) \\
(5 \text { wks }) \\
{ }^{*} P<0.0001\end{array}$ \\
\hline D011.10 & $\begin{array}{l}3.50 \pm \\
0.23(10) \\
(6-8 \text { wks) }\end{array}$ & $\begin{array}{l}6.40 * \pm \\
0.37(9) \\
(6-8 \mathrm{wks}) \\
{ }^{*} P=0.040\end{array}$ & & & & & & & & & & & & \\
\hline
\end{tabular}

One million lymph node cells from adult female versus male mice of varying strains, were labeled with anti-CD4 and anti-CD25 antibodies and analyzed by FACS ${ }^{\circledR}$. The percentage of CD4 ${ }^{+} \mathrm{T}$ cells that expressed $\mathrm{CD} 25^{+}$is presented as Mean \pm SEM. Data were analyzed by student's t test. $*=\mathrm{p}<0.05$. 
Table 3. Analysis of the percentage of $\mathrm{CD}^{+} \mathrm{CD} 25^{+} \mathrm{CD} 103^{+} \mathrm{T}$ cells in female and male mice.

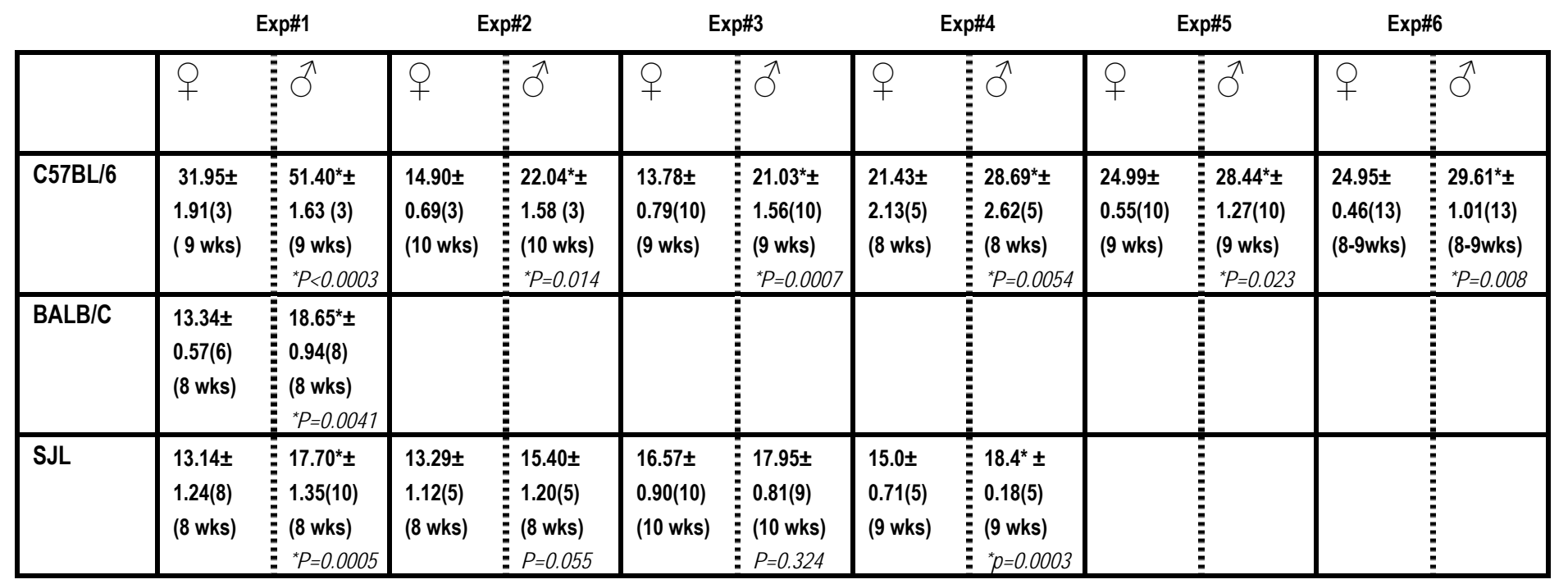

One million lymph node cells from adult mice of varying strains were labeled with anti-CD4, anti-CD25 and anti-CD103 antibodies and analyzed by FACS ${ }^{\circledR}$. The percentage of CD $4^{+}$CD $25^{+}$

T cells expressing $\mathrm{CD}_{103}{ }^{+}$is presented as Mean \pm SEM. Data were analyzed by student's $\mathrm{t}$ test. $*=p<0.05$. 
Table 4a. Mean intensity of expression of CD103, CD45RB, CTLA-4, GITR, and CD62L by female versus male $\mathrm{CD}^{+} \mathrm{CD}^{+} 5^{+} \mathrm{T}$ cells.

\begin{tabular}{|c|c|c|c|c|c|c|}
\hline & \multicolumn{2}{|c|}{ Exp\#1 } & \multicolumn{2}{|c|}{ Exp\#2 } & \multicolumn{2}{|c|}{ Exp\#3 } \\
\hline & $q$ & $\sigma^{1}$ & $q$ & $\sigma^{1}$ & $q$ & 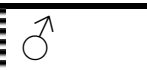 \\
\hline CD62L & $\begin{array}{l}38.1 \pm \\
0.92(10) \\
(9 \text { wks })\end{array}$ & $\begin{array}{l}39.0 \pm \\
1.2(10) \\
(9 \text { wks })\end{array}$ & $\begin{array}{l}54.3 \pm \\
1.7(3) \\
(9 \text { wks) }\end{array}$ & $\begin{array}{l}50.4 \pm \\
1.7(3) \\
(9 \text { wks) }\end{array}$ & $\begin{array}{l}43.6 \pm \\
0.68(10) \\
(9 \text { wks) }\end{array}$ & $\begin{array}{l}49.0 \pm \\
0.34(10) \\
(9 \mathrm{wks})\end{array}$ \\
\hline GITR & $\begin{array}{l}186.4 \pm \\
8.0(10) \\
(9 \text { wks })\end{array}$ & $\begin{array}{l}223.2^{*} \pm \\
10.7(10) \\
(9 \text { wks) } \\
p=0.013 \\
\end{array}$ & $\begin{array}{l}121.6 \pm \\
2.6(10) \\
(9 \text { wks) }\end{array}$ & $\begin{array}{l}121.0 \pm \\
5.1(10) \\
(9 \text { wks) }\end{array}$ & $\begin{array}{l}112.8 \pm \\
1.73(10) \\
(9 \text { wks })\end{array}$ & $\begin{array}{l}100.6 \pm \\
1.23(10) \\
(9 \mathrm{ws})\end{array}$ \\
\hline CD45RB & $\begin{array}{l}95.2 \pm \\
3.0(10) \\
(9 \text { wks) }\end{array}$ & $\begin{array}{l}116.3^{*} \pm \\
7.5(10) \\
(9 \text { wks }) \\
p=0.018\end{array}$ & $\begin{array}{l}640.5 \pm \\
11.2(3) \\
(9 \text { wks) }\end{array}$ & $\begin{array}{l}605.0 \pm \\
16.0(3) \\
(9 \text { wks) }\end{array}$ & $\begin{array}{l}789.0 \pm \\
9.7(10) \\
(9 \text { wks) }\end{array}$ & $\begin{array}{l}796.9 \pm \\
11.5(10) \\
(9 \text { wks) }\end{array}$ \\
\hline CTLA-4 & $\begin{array}{l}235.3 \pm \\
9.3(10) \\
\text { ( } 9 \text { wks) }\end{array}$ & $\begin{array}{l}273.0^{*} \pm \\
15.3(10) \\
(9 \text { wks }) \\
p=0.04\end{array}$ & $\begin{array}{l}272.0 \pm \\
0.4(3) \\
(9 \text { wks) }\end{array}$ & $\begin{array}{l}336.2^{*} \pm \\
1.8(3) \\
(9 \text { wks) } \\
p=0.035\end{array}$ & $\begin{array}{l}258.0 \pm \\
8.4(10) \\
(9 \text { wks) }\end{array}$ & $\begin{array}{l}358.0^{*} \pm \\
18.9(10) \\
(9 \text { wks }) \\
p=0.00032\end{array}$ \\
\hline CD103 & $\begin{array}{l}308.9 \pm \\
6.4(10) \\
(9 \text { wks })\end{array}$ & $\begin{array}{l}331.1 \pm \\
9.6(10) \\
(9 \text { wks })\end{array}$ & $\begin{array}{l}651.2 \pm \\
51.1(3) \\
(9 \text { wks) }\end{array}$ & $\begin{array}{l}811.4^{*} \pm \\
2.4(3) \\
(9 \text { wks }) \\
p=0.035\end{array}$ & $\begin{array}{l}863.3 \pm \\
55.3(10) \\
(9 \text { wks) }\end{array}$ & $\begin{array}{l}911.0 \pm \\
20.5(10) \\
(9 \mathrm{wks})\end{array}$ \\
\hline
\end{tabular}

One million lymph node cells from adult female versus male mice were labeled with anti-CD4, anti-CD25 and anti-CD62L, CD103, CTLA-4, GITR or CD45RB antibodies and analyzed by FACS ${ }^{\circledR}$. Labeled $\mathrm{CD} 4^{+} \mathrm{CD} 25^{+}$T cells were gated and analyzed for the mean intensity of expression of CD62L, CD103, CTLA-4, GITR or CD45RB.

An $*$ indicates a significant difference at $\mathrm{p}<0.05$. 
Table 4b. Mean intensity of expression of CD103, CD45RB, CTLA-4, GITR, and CD62L by intact male versus female, castrated or $\mathrm{Tfm}$ male $\mathrm{CD}^{+}{ }^{+} \mathrm{CD}^{+} 5^{+} \mathrm{T}$ cells.

\begin{tabular}{|c|c|c|c|c|c|c|c|}
\hline & $\begin{array}{c}+ \\
\text { Exp\#1 }\end{array}$ & $\begin{array}{c}\bar{O} \\
\text { Exp\#1 }\end{array}$ & $\begin{array}{l}\text { Castrated } 0 \\
\text { Exp\#1 }\end{array}$ & $\begin{array}{l}\operatorname{Tfm}{ }^{\lambda} \\
\text { Exp\#1 }\end{array}$ & $\begin{array}{c}q \\
\text { Exp\#2 }\end{array}$ & $\begin{array}{c}1 \\
\text { Exp\#2 }\end{array}$ & $\begin{array}{l}\text { Tfm } ठ \\
\text { Exp\#2 }\end{array}$ \\
\hline CD62L & $\begin{array}{l}38.1 \pm \\
0.92(10) \\
(9 \text { wks) }\end{array}$ & $\begin{array}{l}39.0 \pm \\
1.2(10) \\
(9 \text { wss }\end{array}$ & $\begin{array}{l}43.0 \pm \\
0.75(10) \\
(9 \text { wks) }\end{array}$ & $\begin{array}{l}41.3 \pm \\
0.85(10) \\
(9 \text { wks })\end{array}$ & $\begin{array}{l}54.3 \pm \\
1.7(3) \\
(9 \mathrm{wks})\end{array}$ & $\begin{array}{l}50.4 \pm \\
1.7(3) \\
(9 \text { wks })\end{array}$ & $\begin{array}{l}64.6 \pm \\
3.1(3) \\
(9 \text { wks) }\end{array}$ \\
\hline GITR & $\begin{array}{l}186.4 \pm \\
8.0(10) \\
(9 \text { wks) }\end{array}$ & $\begin{array}{l}223.2^{*} \pm \\
10.7(10) \\
(9 \text { wks }) \\
p=0.022\end{array}$ & $\begin{array}{l}133.6 \pm \\
5.1(10) \\
(9 \mathrm{wks})\end{array}$ & $\begin{array}{l}160.4 \pm \\
3.5(10) \\
(9 \text { wks })\end{array}$ & $\begin{array}{l}121.6 \pm \\
2.6(10) \\
(9 \text { wks) }\end{array}$ & $\begin{array}{l}121.0 \pm \\
5.1(10) \\
(9 \mathrm{wks})\end{array}$ & $\begin{array}{l}118.0 \pm \\
3.5(10) \\
\text { (9 wks) }\end{array}$ \\
\hline CD45RB & $\begin{array}{l}95.2 \pm \\
3.0(10) \\
(9 \text { wks) }\end{array}$ & $\begin{array}{l}116.3^{*} \pm \\
7.5(10) \\
(9 \text { wks }) \\
p=0.020\end{array}$ & $\begin{array}{l}95.7 \pm \\
3.9(10) \\
(9 \text { wks) }\end{array}$ & $\begin{array}{l}81.5 \pm \\
3.0(10) \\
(9 \text { wks) }\end{array}$ & $\begin{array}{l}640.5 \pm \\
11.2(3) \\
\text { ( } 9 \text { wks) }\end{array}$ & $\begin{array}{l}605.0 \pm \\
16.0(3) \\
(9 \mathrm{wks})\end{array}$ & $\begin{array}{c}596.2 \pm \\
19.1 \text { (3) } \\
\text { ( } 9 \text { wks }\end{array}$ \\
\hline CTLA-4 & $\begin{array}{l}235.3 \pm \\
9.3(10) \\
(9 \text { wss) }\end{array}$ & $\begin{array}{l}273.0^{*} \pm \\
15.3(10) \\
(9 \text { wks) } \\
p=0.031\end{array}$ & $\begin{array}{l}216.5 \pm \\
8.0(10) \\
\text { ( } 9 \text { wss) }\end{array}$ & $\begin{array}{l}225.3 \pm \\
8.8(10) \\
(9 \text { wks) }\end{array}$ & $\begin{array}{l}272.0 \pm \\
0.4(3) \\
(9 \text { wks) }\end{array}$ & $\begin{array}{l}336.2^{*} \pm \\
1.8(3) \\
(9 \text { wks }) \\
p=0.040\end{array}$ & $\begin{array}{l}203.7 \pm \\
1.8(3) \\
(9 \text { wks) }\end{array}$ \\
\hline CD103 & $\begin{array}{l}308.9 \pm \\
6.4(10) \\
(9 \text { wks) }\end{array}$ & $\begin{array}{l}331.1 \pm \\
9.6(10) \\
(9 \mathrm{wks})\end{array}$ & $\begin{array}{c}326.6 \pm \\
7.4(10) \\
(9 \text { wks) }\end{array}$ & $\begin{array}{l}301.4 \pm \\
6.1(10) \\
(9 \text { wks) }\end{array}$ & $\begin{array}{l}651.2 \pm \\
51.1(3) \\
\text { ( } 9 \text { wks) }\end{array}$ & $\begin{array}{l}811.4^{*} \pm \\
2.4(3) \\
(9 \text { wks }) \\
p=0.024\end{array}$ & $\begin{array}{c}483.0 \pm \\
15.2(3) \\
\text { ( } 9 \text { wks) }\end{array}$ \\
\hline
\end{tabular}

One million lymph node cells from intact male versus female, castrated or Tfm male mice were labeled with anti-CD4, anti-CD25 and anti-CD62L, CD103, CTLA-4, GITR or CD45RB antibodies and analyzed by FACS ${ }^{\circledR}$. Labeled $\mathrm{CD} 4^{+} \mathrm{CD} 25^{+} \mathrm{T}$ cells were gated and analyzed for the mean intensity of expression of CD62L, CD103, CTLA-4, GITR or CD45RB. An * indicates a significant difference at $p<0.05$, with males being significantly higher than female and castrated male (Exp\#1) or female and Tfm male (Exp\#2). 
Table 5a. Absolute numbers of $\mathrm{CD}^{+} \mathrm{CD}^{+} 5^{+} \mathrm{T}$ cells in female and male mice.

\begin{tabular}{|c|c|c|c|c|c|c|}
\hline & \multicolumn{2}{|c|}{ Exp\#1 } & \multicolumn{2}{|c|}{ Exp\#2 } & \multicolumn{2}{|c|}{ Exp\#3 } \\
\hline & q & $\widehat{1}$ & q & $0^{1}$ & q & $0^{\pi}$ \\
\hline C57BL/6 & $\begin{array}{l}5.0 \times 10^{5} \pm \\
41238(10)\end{array}$ & $\begin{array}{l}* 6.6 \times 10^{5} \pm \\
58711(10) \\
p=0.035\end{array}$ & $\begin{array}{l}8.3 \times 10^{5} \pm \\
149470(4)\end{array}$ & $\begin{array}{l}{ }^{*} 1.3 \times 10^{6} \pm \\
154520(5) \\
p=0.044\end{array}$ & $\begin{array}{l}1.1 \times 10^{6} \pm \\
168880(5)\end{array}$ & $\begin{array}{l}1.4 \times 10^{6} \pm \\
237710(5)\end{array}$ \\
\hline BALB/C & $\begin{array}{l}4.4 \times 10^{5} \pm \\
90035(6)\end{array}$ & $\begin{array}{l}* 1.1 \times 10^{6} \pm \\
101410(6) \\
p=0.002\end{array}$ & $\begin{array}{l}2.14 \times 10^{6} \pm \\
92502(8)\end{array}$ & $\begin{array}{l}2.5 \times 10^{6} \pm \\
221140(8)\end{array}$ & & \\
\hline SJL & $\begin{array}{l}7.7 \times 10^{6 \pm} \pm \\
493930(9)\end{array}$ & $\begin{array}{l}9.1 \times 10^{6} \pm \\
437760(9)\end{array}$ & $\begin{array}{l}4.4 \times 10^{6} \pm \\
248990(9)\end{array}$ & $\begin{array}{l}* 5.1 \times 10^{6} \pm \\
158470(9) \\
p=0.029\end{array}$ & $\begin{array}{l}3.0 \times 10^{6} \pm \\
173040(10)\end{array}$ & $\begin{array}{c}* 3.7 \times 10^{6} \pm \\
181800(10) \\
p=0.008\end{array}$ \\
\hline
\end{tabular}

Table 5b. Absolute numbers of $\mathrm{CD}^{+} \mathrm{CD}^{+} 5^{+} \mathrm{CD} 103^{+} \mathrm{T}$ cells in female and male mice.

\begin{tabular}{|c|c|c|c|c|c|c|c|c|}
\hline \multicolumn{2}{|c|}{ Exp\#1 } & \multicolumn{2}{|c|}{ Exp\#2 } & \multicolumn{2}{|c|}{ Exp\#3 } & \multicolumn{2}{|c|}{ Exp\#4 } & \\
\hline & $q$ & $\overline{0}$ & q & $\hat{0}$ & $q$ & $\hat{0}$ & $q$ & $\hat{\sigma}$ \\
\hline C57BL/6 & $\begin{array}{l}1.2 \times 10^{55} \\
3820(9)\end{array}$ & $\begin{array}{l}{ }^{* 1.9 \times 10^{5} \pm} \\
11715(9) \\
p<0.0001\end{array}$ & $\begin{array}{l}3.5 \times 10^{5 \pm} \\
11761(4)\end{array}$ & $\begin{array}{l}3.9 \times 10^{5 \pm} \\
23296(5)\end{array}$ & $\begin{array}{l}4.7 \times 10^{5 \pm} \\
13655(5)\end{array}$ & $\begin{array}{l}{ }^{* 6.1 \times 10^{5} \pm} \\
10563(5) \\
p=0001\end{array}$ & $\begin{array}{l}1.1 \times 10^{55} \\
76541(6)\end{array}$ & $\begin{array}{l}{ }^{* 1.8 \times 10^{5} \pm} \\
65432(6) \\
p<0.0001\end{array}$ \\
\hline BALB/C & $\begin{array}{l}7.7 \times 10^{4 \pm} \\
15364\end{array}$ & $\begin{array}{l}* 2.1 \times 10^{5 \pm} \\
14687 \\
p<0.0001\end{array}$ & $\begin{array}{l}5.0 \times 10^{5 \pm} \\
51436(10)\end{array}$ & $\begin{array}{l}6.8 \times 10^{5 \pm} \\
56608(10) \\
p=0.031\end{array}$ & & & & \\
\hline SJL & $\begin{array}{l}5.5 \times 10^{5 \pm} \\
55930(8)\end{array}$ & $\begin{array}{l}6.4 \times 10^{5 \pm} \\
48633(9)\end{array}$ & $\begin{array}{l}7.6 \times 10^{5 \pm} \\
47922(10)\end{array}$ & $\begin{array}{l}9.3 \times 10^{5 \pm} \\
51548(10) \\
p=0.025\end{array}$ & $\begin{array}{l}5.7 \times 10^{5 \pm} \\
30159(7)\end{array}$ & 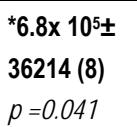 & $\begin{array}{l}5.8 \times 10^{5 \pm} \\
82450(5)\end{array}$ & $\begin{array}{l}6.9 \times 10^{5 \pm} \\
72415(5)\end{array}$ \\
\hline
\end{tabular}

One million lymph node cells from adult mice of varying strains were labeled with anti-CD4, anti-CD25(a) and anti-CD103(b) antibodies and analyzed by FACS ${ }^{\circledR}$. Total numbers were then calculated using total cell counts and the results of FACS $^{\circledR}$ analysis. Data are represented as Mean \pm SEM. Data were analyzed by student's $t$ test. An $*$ indicates a significant difference at $\mathrm{p}<0.05$. 
Table 6a. Comparison of $\mathrm{CD} 4^{+} \mathrm{CD} 25^{+} \mathrm{T}$ cell regulatory function between adult female and male C57BL/6 mice.

\begin{tabular}{|c|c|c|c|c|c|c|}
\hline Experiment & Sex / inhibition & $\overline{1: 1}$ & $1: 2$ & $\overline{1: 4}$ & $\overline{1: 8}$ & $1: 16$ \\
\hline \multirow[t]{2}{*}{ Exp \# 1} & $\begin{array}{c}q \text { (9 wks) } \\
-\end{array}$ & $\begin{array}{c}14572.3 \pm \\
2500.0\end{array}$ & $\begin{array}{c}36145.8 \pm \\
1320.9\end{array}$ & $\begin{array}{c}53698.8 \pm \\
4491.0\end{array}$ & $\begin{array}{c}67401 \pm \\
5554.2\end{array}$ & $\begin{array}{c}84540 \pm \\
3104.9\end{array}$ \\
\hline & $\begin{array}{c}{ }^{\wedge} \text { (9wks) } \\
-\end{array}$ & $\begin{array}{c}10831.3 \pm \\
552.8\end{array}$ & $\begin{array}{c}26274.8 \pm \\
1831.9\end{array}$ & $\begin{array}{c}48461.8 \pm \\
2951.6\end{array}$ & $\begin{array}{c}49082.0 \pm \\
4836.2\end{array}$ & $\begin{array}{c}63060.3 \pm \\
4399.0\end{array}$ \\
\hline \multirow{2}{*}{ Exp \# 2} & $\begin{array}{c}q \text { (10wks) } \\
-\end{array}$ & $\begin{array}{c}48624.5 \pm \\
2135.7\end{array}$ & $\begin{array}{c}45010.8 \pm \\
2967.9\end{array}$ & $\begin{array}{c}49141.0 \pm \\
2036.2\end{array}$ & $\begin{array}{c}63541.3 \pm \\
1977.7\end{array}$ & $\begin{array}{c}50430.3 \pm \\
4524.3\end{array}$ \\
\hline & $\begin{array}{c}\sigma^{\lambda} \text { (10wks) } \\
-\end{array}$ & $\begin{array}{c}47430.7 \pm \\
639.6\end{array}$ & $\begin{array}{c}45971.0 \pm \\
2896.6\end{array}$ & $\begin{array}{c}47372.8 \pm \\
1236.9\end{array}$ & $\begin{array}{c}52883.8 \pm \\
4382.0\end{array}$ & $\begin{array}{c}45085.3 \pm \\
7416.5\end{array}$ \\
\hline \multirow[t]{2}{*}{ Exp \#3 } & $\begin{array}{c}q \text { (9 wks) } \\
-\end{array}$ & $\begin{array}{c}27953.5 \pm \\
2495.9\end{array}$ & $\begin{array}{c}39369.8 \pm \\
3316.3\end{array}$ & $\begin{array}{c}60868.7 \pm \\
2508.2\end{array}$ & $\begin{array}{c}73847.7 \pm \\
686.6\end{array}$ & $\begin{array}{c}75616.5 \pm \\
695.5\end{array}$ \\
\hline & $\begin{array}{c}\text { (9wks) } \\
-\end{array}$ & $\begin{array}{c}39825.8 \pm \\
6009.7\end{array}$ & $\begin{array}{c}42554.8 \pm \\
3662.6\end{array}$ & $\begin{array}{c}45765.7 \pm \\
3359.0\end{array}$ & $\begin{array}{c}77239.3 \pm \\
7340.6\end{array}$ & $\begin{array}{c}71425.0 \pm \\
6793.0\end{array}$ \\
\hline \multirow[t]{2}{*}{ Exp \#4 } & $\begin{array}{c}\text { क (10wks) } \\
\downarrow\end{array}$ & $\begin{array}{c}16609.0 \pm \\
2335.5\end{array}$ & $\begin{array}{c}19423.0 \pm \\
1295.8\end{array}$ & $\begin{array}{c}23104.0 \pm \\
1046.3\end{array}$ & $\begin{array}{c}26403.8 \pm \\
1912.8\end{array}$ & $\begin{array}{c}33724.0 \pm \\
1316.1\end{array}$ \\
\hline & $\begin{array}{c}\text { रे (10wks) } \\
-\end{array}$ & $\begin{array}{c}7439.2 \pm \\
656.3\end{array}$ & $\begin{array}{c}11353.8 \pm \\
943.4\end{array}$ & $\begin{array}{c}14740.8 \pm \\
937.2\end{array}$ & $\begin{array}{c}20822.0 \pm \\
1926.6\end{array}$ & $\begin{array}{c}33049.2 \pm \\
2199.9\end{array}$ \\
\hline \multirow[t]{2}{*}{ Exp\# 5} & $\begin{array}{c}q \text { (9 wks) } \\
\downarrow\end{array}$ & $\begin{array}{c}17887.0 \pm \\
1633.0\end{array}$ & $\begin{array}{c}30733.5 \pm \\
4327.3\end{array}$ & $\begin{array}{c}34856.3 \pm \\
3184.2\end{array}$ & $\begin{array}{c}45629.5 \pm \\
2972.3\end{array}$ & $\begin{array}{c}58450.2 \pm \\
5484.7\end{array}$ \\
\hline & $\begin{array}{c}\text { ○ (9wks) } \\
-\end{array}$ & $\begin{array}{c}8787.5 \pm \\
687.8\end{array}$ & $\begin{array}{c}15743.2 \pm \\
1421.5\end{array}$ & $\begin{array}{c}29981.7 \pm \\
3013.4\end{array}$ & $\begin{array}{c}* 37531.5 \pm \\
2284.3\end{array}$ & $\begin{array}{c}{ }^{*} 46227.5 \pm \\
8891.5\end{array}$ \\
\hline \multirow[t]{2}{*}{ Exp \# 6} & $\begin{array}{c}q \text { (8 wks) } \\
-\end{array}$ & $\begin{array}{c}4105.8 \pm \\
249.7\end{array}$ & $\begin{array}{c}11102.0 \pm \\
2451.1\end{array}$ & $\begin{array}{c}27744.7 \pm \\
2312.0\end{array}$ & $\begin{array}{c}44579.3 \pm \\
4263.4\end{array}$ & $\begin{array}{c}54440.0 \pm \\
1401.2\end{array}$ \\
\hline & $\begin{array}{c}\text { (8 wks) } \\
-\end{array}$ & $\begin{array}{c}3631.7 \pm \\
389.1\end{array}$ & $\begin{array}{c}6471.0 \pm \\
729.2\end{array}$ & $\begin{array}{c}20020.8 \pm \\
1261.8\end{array}$ & $\begin{array}{c}44800.3 \pm \\
2933.3\end{array}$ & $\begin{array}{c}55991.5 \pm \\
3653.8\end{array}$ \\
\hline \multirow[t]{2}{*}{ Exp \# 7} & $\begin{array}{c}q \text { (9 wks) } \\
\downarrow\end{array}$ & $\begin{array}{c}2702.0 \pm \\
295.0\end{array}$ & $\begin{array}{c}9547.5 \pm \\
798.6\end{array}$ & $\begin{array}{c}26602.3 \pm \\
713.9\end{array}$ & $\begin{array}{c}42807.7 \pm \\
3933.8\end{array}$ & $\begin{array}{c}62084.2 \pm \\
3964.2\end{array}$ \\
\hline & $\begin{array}{c}\text { (9wks) } \\
-\end{array}$ & $\begin{array}{c}1789.5 \pm \\
195.6\end{array}$ & $\begin{array}{c}4240.2 \pm \\
243.3\end{array}$ & $\begin{array}{c}9438.0 \pm \\
1407.3\end{array}$ & $\begin{array}{c}19332.0 \pm \\
2195.6\end{array}$ & 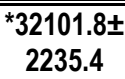 \\
\hline
\end{tabular}


Table 6b. Comparison of $\mathrm{CD} 4^{+} \mathrm{CD} 25^{+} \mathrm{T}$ cell regulatory function between adult female and male SJL mice.

\begin{tabular}{|c|c|c|c|c|c|c|}
\hline Experiment & Sex / inhibition & 1:1 & $1: 2$ & $1: 4$ & $1: 8$ & 1:16 \\
\hline \multirow{2}{*}{ Exp \# 1} & $\begin{array}{c}q \text { (8 wks) } \\
-\end{array}$ & $47710 \pm 585$ & $77378 \pm 3519$ & $104669 \pm 4920$ & $116186 \pm 6298$ & $127992 \pm 3133$ \\
\hline & $\begin{array}{c}\text { (8 } \mathbf{~ w k s )} \\
-\end{array}$ & $40939 \pm 1763$ & $\overline{c 53008 \pm 2658}$ & $95212 \pm 5496$ & $102979 \pm 4603$ & $113525 \pm 7131$ \\
\hline \multirow{2}{*}{ Exp \# 2} & $\begin{array}{c}\text { (9 wks) } \\
\downarrow\end{array}$ & $10456 \pm 1000$ & $23791 \pm 1269$ & $27301 \pm 2464$ & $44787 \pm 10154$ & $53657 \pm 5059$ \\
\hline & $\begin{array}{c}\delta^{\lambda} \text { (9 wks) } \\
-\end{array}$ & $9823 \pm 1030$ & *10858 \pm 2193 & "20715 44302 & "30895 £ 2184 & "35758 \pm 5516 \\
\hline \multirow{2}{*}{ Exp \#3 } & $\begin{array}{c}\text { क (9 wks) } \\
\downarrow \\
\end{array}$ & $7500 \pm 1120$ & $24700 \pm 3330$ & $30800 \pm 3460$ & $41200 \pm 1290$ & $51200 \pm 5850$ \\
\hline & $\begin{array}{c}\text { (9wks) } \\
-\end{array}$ & $6240 \pm 1050$ & 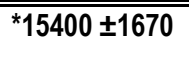 & ${ }^{*} 21800 \pm 3490$ & ${ }^{*} 38000 \pm 2340$ & $51100 \pm 3640$ \\
\hline \multirow[b]{2}{*}{ Exp \#4 } & $\begin{array}{c}\text { P (10wks) } \\
-\end{array}$ & $48934 \pm 2013$ & $70421 \pm 4816$ & $78583 \pm 4970$ & $93743 \pm 4520$ & $104246 \pm 4270$ \\
\hline & $\begin{array}{c}\delta^{1} \text { (10wks) } \\
-\end{array}$ & $49994 \pm 1268$ & $67411 \pm 1309$ & $76287 \pm 3000$ & $99949 \pm 7000$ & $\overline{101658 \pm 4044}$ \\
\hline \multirow{2}{*}{ Exp\# 5} & $\begin{array}{c}q \text { (8 wks) } \\
- \\
\end{array}$ & $29735 \pm 2499$ & $40370 \pm 2322$ & $67869 \pm 3345$ & $103446 \pm 3421$ & $107567 \pm 4356$ \\
\hline & $\begin{array}{c}\partial^{\lambda} \text { (8wks) } \\
-\end{array}$ & $28549 \pm 1197$ & $37831 \pm 1309$ & $61982 \pm 2939$ & $94658.5 \pm 5432$ & $101658 \pm 6754$ \\
\hline
\end{tabular}

$\mathrm{CD} 4^{+} \mathrm{CD} 25^{-}$responder cells were co-cultured with varying numbers of adult female versus male $\mathrm{CD} 4{ }^{+} \mathrm{CD} 25^{+}$regulatory T cells, APCs, and $0.5 \mathrm{mg} / \mathrm{ml}$ anti-CD3 for three days, and subsequently pulsed with ${ }^{3} \mathrm{H}$-Thymidine for 18 hours. Cells were harvested and analyzed for ${ }^{3} \mathrm{H}$-Thymidine uptake (counts per minute, CPM). $\quad-=$ no difference; $\downarrow=$ inhibition by females $<$ males. Data are represented as Mean $\mathrm{CPM} \pm \mathrm{SEM}$.

Data were analyzed by student's $\mathrm{t}$ test. An * indicates a significant difference at $\mathrm{p}<0.05$. 
Table 7a. Comparison of $\mathrm{CD} 4^{+} \mathrm{CD}^{+} 5^{+} \mathrm{CD} 103^{+} \mathrm{T}$ cell regulatory function between female and male $\mathrm{C} 57 \mathrm{BL} / 6$ mice.

$\begin{array}{llll}\text { Exp\#1 Exp\#2 Exp\#3 } & \text { Exp\#4 }\end{array}$

\begin{tabular}{|c|c|c|c|c|c|c|}
\hline Experiment & Sex / inhibition & $1: 1$ & $1: 2$ & $1: 4$ & $1: 8$ & $1: 16$ \\
\hline \multirow{2}{*}{ Exp\# 1} & $\begin{array}{c}\text { ㅇ (9 wks) } \\
\downarrow\end{array}$ & $42204 \pm 3080$ & $73579 \pm 4646$ & $99767 \pm 3620$ & $102436 \pm 5390$ & $121766 \pm 1723$ \\
\hline & $\begin{array}{c}\sigma^{\lambda} \text { (9 wks) } \\
-\end{array}$ & "*13736 \pm 766 & "43694 \pm 716 & 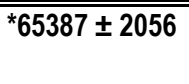 & $95309 \pm 1766$ & ${ }^{*} 100302 \pm 4264$ \\
\hline \multirow{2}{*}{ Exp \# 2} & $\begin{array}{c}\text { ㅇ (10 wks) } \\
\quad \downarrow\end{array}$ & $4426 \pm 1579$ & $8842 \pm 1525$ & $19752 \pm 1314$ & $28007 \pm 5262$ & $40073 \pm 1496$ \\
\hline & $\begin{array}{c}\partial^{\lambda} \text { (10 wks) } \\
-\end{array}$ & ${ }^{*} 675 \pm 58$ & *3731 \pm 884 & ${ }^{*} 10934 \pm 1591$ & ${ }^{*} 17697 \pm 1836$ & $35815 \pm 4878$ \\
\hline \multirow{2}{*}{ Exp \#3 } & $\begin{array}{c}\text { (9 wks) } \\
-\end{array}$ & & $12418 \pm 876$ & $28420 \pm 2506$ & $48087 \pm 5278$ & $60949 \pm 5322$ \\
\hline & $\begin{array}{c}\sigma^{\pi}(9 \text { wks }) \\
-\end{array}$ & & $13353 \pm 709$ & $31139 \pm 5176$ & $45781 \pm 5581$ & $64992 \pm 8833$ \\
\hline \multirow{2}{*}{ Exp \#4 } & $\begin{array}{c}+ \text { (8 wks) } \\
\downarrow \\
\end{array}$ & $6700 \pm 1017$ & $14864 \pm 1362$ & $38207 \pm 9175$ & $81501 \pm 9164$ & \\
\hline & $\begin{array}{c}\text { (8 }(8 \mathrm{wks}) \\
-\end{array}$ & ${ }^{*} 3025 \pm 521$ & 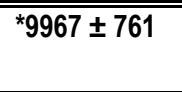 & ${ }^{* 18886 \pm 1876}$ & ${ }^{\star} 38660 \pm 2000$ & \\
\hline \multirow{2}{*}{ Exp\# 5} & $\begin{array}{c}\text { ㅇ (9 wks) } \\
\downarrow \\
\end{array}$ & $13183 \pm 2537$ & $20071 \pm 5337$ & $26712 \pm 3426$ & $49560 \pm 1523$ & $48136 \pm 6672$ \\
\hline & $\begin{array}{c}1 \\
\\
-\end{array}$ & *5229 \pm 256 & *14080 914 & $24809 \pm 2545$ & $47035 \pm 4467$ & $\star 37716 \pm 4692$ \\
\hline
\end{tabular}

$\mathrm{CD} 4^{+} \mathrm{CD} 25^{-}$responder cells were co-cultured with varying numbers of adult female versus male $\mathrm{CD} 4{ }^{+} \mathrm{CD} 25^{+} \mathrm{CD} 103^{+}$regulatory $\mathrm{T}$ cells, APCs, and $0.5 \mathrm{mg} / \mathrm{ml}$ anti-CD3 for three days, and subsequently pulsed with ${ }^{3} \mathrm{H}$-Thymidine for 18 hours. Cells were harvested and analyzed for ${ }^{3} \mathrm{H}$-Thymidine uptake (counts per minute, CPM). - - = no difference; $\downarrow=$ inhibition by females $<$ males. Data are represented as Mean CPM $\pm \mathrm{SEM}$.

Data were analyzed by student's t test. An * indicates a significant difference at $\mathrm{p}<0.05$. 
Table 7b. Comparison of $\mathrm{CD}^{+} \mathrm{CD}^{+} 5^{+} \mathrm{CD} 103^{+} \mathrm{T}$ cell regulatory function between female and male SJL mice.

\begin{tabular}{|c|c|c|c|c|c|c|}
\hline Experiment & Sex / inhibition & $1: 1$ & $1: 2$ & $1: 4$ & $1: 8$ & 1:16 \\
\hline \multirow{2}{*}{ Exp \# 1} & $\begin{array}{c}\text { o (8 wks) } \\
-\end{array}$ & $2879 \pm 195$ & $5559 \pm 1006$ & $12335 \pm 2206$ & $11262 \pm 669$ & $15619 \pm 1824$ \\
\hline & $\begin{array}{c}\partial^{\lambda} \text { (8 wks) } \\
-\end{array}$ & $\overline{c 1589 \pm 216}$ & $=3425 \pm 233$ & $\overline{c 10815 \pm 1649}$ & $12558 \pm 1354$ & $15768 \pm 1006$ \\
\hline \multirow{2}{*}{ Exp \#2 } & $\begin{array}{c}+ \text { (9 wks) } \\
\downarrow\end{array}$ & $7570 \pm 758$ & $9220 \pm 282$ & $14000 \pm 1760$ & $24900 \pm 3250$ & $26700 \pm 1580$ \\
\hline & $\begin{array}{c}\text { (9 wks) } \\
-\end{array}$ & $\overline{~ * 3810 \pm 594}$ & " & ${ }^{*} 10100 \pm 700$ & ${ }^{*} 11500 \pm 1710$ & $25400 \pm 1570$ \\
\hline \multirow{2}{*}{ Exp \#3 } & $\begin{array}{c}\text { q (8 wks) } \\
-\end{array}$ & $1042 \pm 114$ & $1779 \pm 258$ & $3430 \pm 761$ & $5401 \pm 693$ & $9290 \pm 1221$ \\
\hline & \begin{tabular}{c}
\multirow{0}{*}{ (8 wks) } \\
-
\end{tabular} & $866 \pm 69$ & $11104 \pm 119$ & 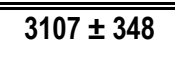 & 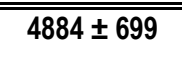 & $8196 \pm 958$ \\
\hline
\end{tabular}

$\mathrm{CD} 4^{+} \mathrm{CD} 25^{-}$responder cells were co-cultured with varying numbers of adult female versus male $\mathrm{CD} 4{ }^{+} \mathrm{CD} 25^{+} \mathrm{CD} 103^{+}$regulatory $\mathrm{T}$ cells, APCs, and $0.5 \mathrm{mg} / \mathrm{ml}$ anti-CD3 for three days, and subsequently pulsed with ${ }^{3} \mathrm{H}$-Thymidine for 18 hours. Cells were harvested and analyzed for ${ }^{3} \mathrm{H}$-Thymidine uptake (counts per minute, $\mathrm{CPM}$ ). - - = no difference; $\downarrow=$ inhibition by females $<$ males. Data are represented as Mean $\mathrm{CPM} \pm \mathrm{SEM}$.

Data were analyzed by student's t test. An* indicates a significant difference at $\mathrm{p}<0.05$. 
Table 8a. Analysis of the percentage of $\mathrm{CD}^{+} \mathrm{CD} 25^{+}$

$T$ cells in castrated mice.

\begin{tabular}{|c|c|c|}
\hline & $\begin{array}{l}\text { Sham castrated } \\
\text { or naive wild-type. }\end{array}$ & Castrated \\
\hline $\begin{array}{l}\text { Sex } \\
\text { Sex........ } \\
\text { treated }\end{array}$ & 3 & o \\
\hline $\begin{array}{l}\text { Exp\#1 } \\
\text { (C57BL/6) }\end{array}$ & $\begin{array}{ll}10.96 \pm 0.65(10) & 13.30^{\star} \pm 0.50(9) \\
(9 \text { wks }) & (9 \text { wks })\end{array}$ & $\begin{aligned} & 10.16 \pm 0.13(9) 8.20 \pm 0.48(9) \\
&(9 \mathrm{wks})\end{aligned}$ \\
\hline $\begin{array}{l}\text { Exp\#2 } \\
\text { (SJL) }\end{array}$ & $\begin{array}{ll}8.46 \pm 0.18(10) & 10.51^{*} \pm 0.58(9) \\
(7 \mathrm{wks}) & (7 \mathrm{wks})\end{array}$ & $\begin{array}{ll}7.93 \pm 0.13(9) & 8.76 \pm 0.26(9) \\
(7 \mathrm{wks}) & (10 \mathrm{wks})\end{array}$ \\
\hline $\begin{array}{l}\text { Exp\#3 } \\
\text { (Balb/c) }\end{array}$ & $\begin{array}{l}7.91 \pm 0.26(3) \\
(10 \text { wks })\end{array}$ & $\begin{array}{ll}6.70 \pm 0.43(3) & 6.34 \pm 0.23(8) \\
(7 \mathrm{wks}) & (7 \mathrm{wks})\end{array}$ \\
\hline
\end{tabular}

Table 8b. Analysis of the percentage of $\mathrm{CD}^{+} \mathrm{CD} 25^{+}$

$\mathrm{T}$ cells in $\mathrm{Tfm}$ male mice.

\begin{tabular}{|c|c|c|}
\hline & Wild- type male & Tfm male \\
\hline Exp\#1 & $26.40^{\star} \pm 0.63(3)$ & $22.10 \pm 0.59(3)$ \\
\hline (B6, Tfm) & (9 wks) & (9 wks) \\
\hline Exp\#2 & $20.58^{*} \pm 0.23(3)$ & $13.50 \pm 1.66(3)$ \\
\hline (B6, Tfm) & (10 wks) & (10 wks) \\
\hline Exp\#3 & $13.30^{*} \pm 0.50(9)$ & $8.19 \pm 0.68(9)$ \\
\hline (B6, Tfm) & (9 wks) & (9 wks) \\
\hline Exp\#4 & $10.45 \pm 0.46(9)$ & $9.80 \pm 0.29(8)$ \\
\hline (B6, Tfm & (9 wks) & (9 wks) \\
\hline Exp\#5 & $12.00 \pm 0.37(6)$ & $14.70 \pm 0.48(5)$ \\
\hline (B6, Tfm & (9 wks) & (9 wks) \\
\hline
\end{tabular}

Table 8c. Analysis of the percentage of $\mathrm{CD}^{+} \mathrm{CD}^{+} 5^{+} \mathrm{T}$ cells in androgen pellet-treated female mice.

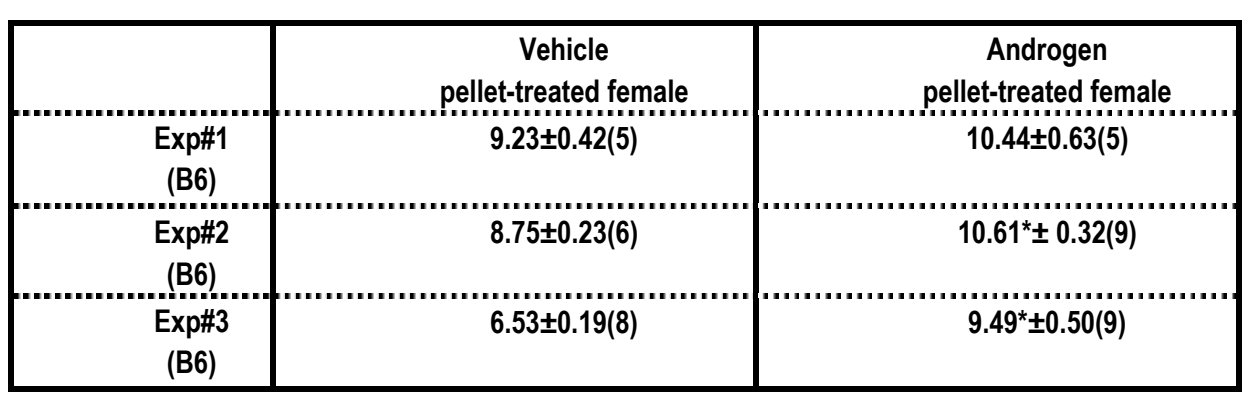

One million lymph node cells from adult castrated or sham castrated female or male, Tfm male or vehicle or androgen pellet-treated female mice of varying strains, were labeled with anti-CD4 and anti-CD25 antibodies and analyzed by FACS ${ }^{\circledR}$.

The percentage of $\mathrm{CD}^{+} \mathrm{T}$ cells that expressed $\mathrm{CD} 25^{+}$is presented as Mean \pm SEM. Data were analyzed by student's $\mathrm{t}$ test. An* indicates a significant difference at $\mathrm{p}<0.05$. 
Table 9. Percentage of $\mathrm{CD}^{+} \mathrm{CD} 25^{+} \mathrm{CD}{ }^{+} 3^{+} \mathrm{T}$ cells in intact female or intact or castrated or $\mathrm{Tfm}$ male and androgen pellet-treated female.

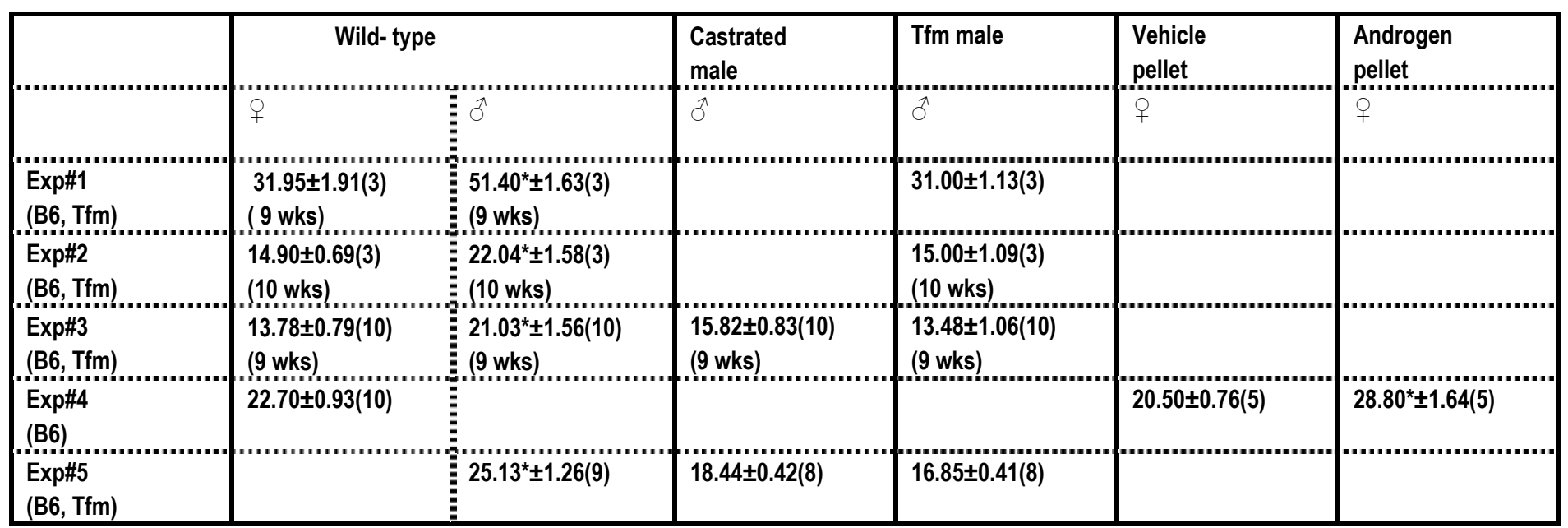

One million lymph node cells from intact female, or intact or castrated or Tfm male, or vehicle or androgen

pellet-treated mice were labeled with anti-CD4, anti-CD25 and anti-CD103 antibodies and analyzed by FACS ${ }^{\circledR}$.

The percentage of $\mathrm{CD} 4^{+} \mathrm{CD} 25^{+} \mathrm{T}$ cells expressing $\mathrm{CD}_{103^{+}}$is presented as Mean $\pm \mathrm{SEM}$. Data were analyzed

by student's $t$ test. An * indicates a significant difference at $\mathrm{p}<0.05$. 
Table 10. Comparison of suppression by regulatory $\mathrm{CD}^{+} \mathrm{CD} 25^{+} \mathrm{CD} 103^{+} \mathrm{T}$ cells from intact female or intact or castrated or $\mathrm{Tfm}$ male mice.

\begin{tabular}{|c|c|c|c|c|c|c|}
\hline Experiment & $\begin{array}{l}\text { Treatment \& } \\
\text { inhibition }\end{array}$ & 1:1 & $1: 2$ & $1: 4$ & $1: 8$ & $1: 16$ \\
\hline \multirow{4}{*}{$\begin{array}{l}\text { Exp \#1 } \\
\text { (B6, Tfm) }\end{array}$} & $\begin{array}{c}\text { Castrated } \widehat{\delta} \\
\downarrow\end{array}$ & $2260 \pm 1417$ & $3374 \pm 325$ & $10237 \pm 1468$ & $27752 \pm 2624$ & $53830 \pm 2005$ \\
\hline & $\begin{array}{c}\text { Wild-type }{ }^{\circ} \\
\downarrow\end{array}$ & $4426 \pm 1579$ & $8842 \pm 1321$ & $19752 \pm 1314$ & $28007 \pm 5262$ & $40073 \pm 1496$ \\
\hline & $\begin{array}{c}\text { Wild-type }{ }^{\hat{O}} \\
-\end{array}$ & ${ }^{*} 675 \pm 58$ & *3731 4884 & "*10934 \pm 1591 & *17697士 1836 & $35815 \pm 4878$ \\
\hline & $\begin{array}{c}\operatorname{Tfm}^{\uparrow} \\
\downarrow\end{array}$ & $2934 \pm 606$ & $8147 \pm 949$ & $21433 \pm 5183$ & $29405 \pm 10424$ & $32806 \pm 4259$ \\
\hline \multirow{4}{*}{$\begin{array}{l}\text { Exp \# } 2 \\
(B 6, T f m)\end{array}$} & $\begin{array}{c}\text { Castrated } \lesssim \\
\downarrow\end{array}$ & $2142 \pm 119$ & $2794 \pm 555$ & $3887 \pm 725$ & $5521 \pm 386$ & $3837 \pm 469$ \\
\hline & $\begin{array}{c}\text { Wild-type }+ \\
\downarrow\end{array}$ & $2913 \pm 809$ & $\overline{4} 4764 \pm 717$ & $4 \quad 4392 \pm 557$ & $6652 \pm 216$ & $7798 \pm 592$ \\
\hline & $\begin{array}{c}\text { Wild-type }{ }^{\Uparrow} \\
-\end{array}$ & ${ }^{*} 553 \pm 81$ & ${ }^{*} 952 \pm 185$ & "1953 & 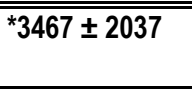 & $\overline{5309 \pm 632}$ \\
\hline & $\begin{array}{c}\operatorname{Tfm}{ }^{\lambda} \\
\downarrow\end{array}$ & $2417 \pm 447$ & $3876 \pm 202$ & $3839 \pm 529$ & $16482 \pm 1270$ & $13781 \pm 1039$ \\
\hline \multirow{4}{*}{$\begin{array}{l}\text { Exp \# } 3 \\
\text { (B6, Tfm) }\end{array}$} & $\begin{array}{c}\text { Castrated } \sigma^{\lambda} \\
\downarrow\end{array}$ & $16816 \pm 3178$ & $37140 \pm 4233$ & $53738 \pm 3820$ & $59061 \pm 4690$ & $59957 \pm 5352$ \\
\hline & $\begin{array}{c}\text { Wild-type } q \\
\downarrow \\
\end{array}$ & $14572 \pm 2500$ & $36146 \pm 1321$ & $53700 \pm 4491$ & $67401 \pm 5554$ & $84540 \pm 3105$ \\
\hline & $\begin{array}{c}\text { Wild-type }{ }^{\lambda} \\
- \\
\end{array}$ & 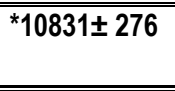 & ${ }^{*} 26275 \pm 1832$ & *48462 \pm 2952 & $\overline{56844 \pm 2124}$ & $61432 \pm 3245$ \\
\hline & $\begin{array}{c}\operatorname{Tfm} \delta^{\Uparrow} \\
\downarrow\end{array}$ & $18599 \pm 2016$ & $36726 \pm 2271$ & $44947 \pm 846$ & $56470 \pm 1389$ & $62639 \pm 5425$ \\
\hline
\end{tabular}

$\mathrm{CD} 4^{+} \mathrm{CD} 25^{-}$responder cells were co-cultured with $\mathrm{CD} 4^{+} \mathrm{CD} 25^{+} \mathrm{CD} 2103^{+}$regulatory $\mathrm{T}$ cells from intact female, or intact or castrated or Tfm male mice, APCs, and $0.5 \mathrm{mg} / \mathrm{ml}$ anti-CD3 for three days, and subsequently pulsed with ${ }^{3} \mathrm{H}$-Thymidine for 18 hours. Cells were harvested and analyzed for ${ }^{3} \mathrm{H}$-Thymidine uptake (counts per minute, CPM). - - = no difference; $\downarrow=$ inhibition by females $<$ males. Data are represented as Mean $\mathrm{CPM} \pm \mathrm{SEM}$.

Data were analyzed by student's t test. An * indicates a significant difference at $\mathrm{p}<0.05$. 


\section{SPECIFIC AIM II}

\section{Assessing the influence of estrogens (estradiol) on $\mathrm{CD}^{+} \mathrm{CD} 25^{+}$regulatory $\mathrm{T}$ cell number and function.}

Within the past two decades, there has been extensive study on the reasons why autoimmune diseases such as rheumatoid arthritis, multiple sclerosis and systemic lupus erythematosus are more prevalent in women than men. In general, females exhibit a more potent immune response than males, for example; females mount higher antibody responses to many microorganisms and elicit more vigorous $\mathrm{T}$ cell activation than males, reject allografts more readily, and display a reduced incidence of certain tumors.

Furthermore, the proinflammatory (IL-1 secretion) and TH1-mediated (e.g., IFN- $\gamma$ secretion) responses observed in females are also greater than those observed in males $(106,107)$. Studies have shown that this phenomenon of enhanced immunity in female mice is reminiscent of a similar situation in female humans, and may be mediated by the predominantly female sex steroid, estrogen through mechanism(s) which are currently unknown $(114-119,181)$. In the following experiments, we evaluated the effect of estrogens on $\mathrm{CD} 4{ }^{+} \mathrm{CD} 25^{+}$regulatory cell numbers, phenotype and function. 


\section{Estrus cycle has a small influence on the numbers and function of $\mathrm{CD}^{+} \mathrm{CD} 25^{+}$ regulatory cells.}

The reproductive process in the female mouse is characterized by cyclic hormonal fluctuations which correspond to the emergence or disappearance of characteristic cells in the reproductive tract, in a process known as the estrous cycle. The different stages of the estrous cycle which occur in the whole of the reproductive tract (ovary, uterus and vagina) are morphologically distinct, and the changes which occur during these stages can be observed in stained smears prepared from the vaginal fluid. By microscopic examination of smears, the diestrus, estrus and proestrus stages of the estrous cycle in mice can be distinguished (Figure 26A). During the diestrus stage of the estrous cycle, blood estrogen levels are low, then suddenly peak during proestrus, and then drop again during the estrous stage (Figure 26B).

In the following experiments, we evaluated the effects of normal changes in physiological levels of estrogen on the number and regulatory function of $\mathrm{CD} 4{ }^{+} \mathrm{CD} 25^{+} \mathrm{T}$ cells by comparing these parameters in mice during the proestrus (high estrogen levels), diestrus or estrus (low estrogen levels) stages of the estrous cycle. Briefly, 8 week old female mice were monitored for the stage of estrous cycle by evaluating vaginal smears daily for a period of 2-3 weeks. Cells from individual mice at various stages of the estrous cycle, were labeled to determine the percentage of $\mathrm{CD} 4^{+} \mathrm{CD} 25^{+}$and $\mathrm{CD} 4{ }^{+} \mathrm{CD} 25^{+} \mathrm{CD} 103^{+}$regulatory $\mathrm{T}$ cells. We found that the percentages of $\mathrm{CD} 4{ }^{+} \mathrm{CD} 25^{+}$ and $\mathrm{CD} 4^{+} \mathrm{CD} 25^{+} \mathrm{CD} 103^{+}$cells from each stage were not significantly different between diestrus, proestrus and estrus (Figure 27A \& B). However, the percentage of 
$\mathrm{CD} 4^{+} \mathrm{CD} 25^{+}$and $\mathrm{CD} 4^{+} \mathrm{CD} 25^{+} \mathrm{CD} 103^{+}$cells from male mice were significantly higher than those from female (and Tfm) mice at all stages of estrous (Figure 27A \& B).

The following experiments were performed to determine whether different stages of the estrous cycle can affect regulatory cell function. For in vitro proliferation assays, the suppressive ability of $\mathrm{CD} 4^{+} \mathrm{CD} 25^{+}$cells harvested from mice at each stage of the estrous cycle was tested. Varying ratios of $\mathrm{CD} 4^{+} \mathrm{CD} 25^{+}$regulatory $\mathrm{T}$ cells : $\mathrm{CD} 4^{+} \mathrm{CD} 25^{-}$ responder cells from mice at each stage were co-cultured with $\mathrm{CD} 4^{+} \mathrm{CD} 25^{-}$responder $\mathrm{T}$ cells, APCs and anti CD3 antibody. Our results indicated that $\mathrm{CD} 4{ }^{+} \mathrm{CD} 25^{+}$regulatory $\mathrm{T}$ cells from C57BL/6 female mice in proestrus (i.e., stage with higher levels of estrogen) were slightly less effective than male mice in regulating proliferation of responder cells (Figure 28A \& B). The diestrus $\mathrm{CD} 4^{+} \mathrm{CD} 25^{+}$regulatory $\mathrm{T}$ cells were also slightly better than the proestrus in regulating the proliferation of responder cells, but were not different from either the male or female at estrus (Figure 28A \& B). In subsequent experiments, we also determined whether there were differences in the expression of Foxp3 by $\mathrm{CD}^{+} \mathrm{CD} 25^{+}$cells from different stages of the estrus cycle. Foxp3 mRNA from $\mathrm{CD} 4{ }^{+} \mathrm{CD} 25^{+}$cells was quantified by real-time PCR in wild-type C57BL/6 mice. Our results indicated that there were no significant differences in Foxp3 expression by $\mathrm{CD}^{+} \mathrm{CD} 25^{+} \mathrm{T}$ cells from diestrus, estrus or proestrus (Figure 29). Moreover, male $\mathrm{CD}^{+} \mathrm{CD} 25^{+}$cells did not express higher levels of Foxp3 than females at any stage of the estrous cycle. Our results indicated that the numbers and function of regulatory $\mathrm{T}$ cells in male mice with high testosterone levels were somewhat greater than female mice at proestrus with high estrogen levels. Moreover, $\mathrm{CD} 4{ }^{+} \mathrm{CD} 25^{+}$regulatory $\mathrm{T}$ cells from female mice in diestrus with low estrogen levels, were slightly better in inhibiting the 
proliferation of responder $\mathrm{T}$ cells, compared with $\mathrm{CD} 4{ }^{+} \mathrm{CD} 25^{+}$from female mice in proestrus with high estrogen levels. Based on these results, we concluded that physiological levels of estrogens may have little or no effects on $\mathrm{CD} 4{ }^{+} \mathrm{CD} 25^{+}$regulatory cells.

\section{Estrogens do not have a direct effect on $\mathrm{CD}^{+} \mathrm{CD}^{2} 5^{+} \mathrm{T}$ cell function in vitro.}

The following experiments were performed to determine whether estrogen has a direct effect on regulatory $\mathrm{T}$ cells function in vitro. For these experiments, purified female wild-type C57BL/6 or estrogen receptor $(\alpha \& \beta)$ knockout (ERKO) $\mathrm{CD} 4^{+} \mathrm{CD} 25^{+}$ $\mathrm{T}$ cells were analyzed for their ability to regulate in the presence of varying concentrations of estradiol. Our results showed that there were no differences in proliferation between $\mathrm{CD} 4{ }^{+} \mathrm{CD} 25^{+} \mathrm{T}$ cells treated with increasing doses of estradiol or vehicle (ethanol) control (Figure 30). These results suggested that estradiol may not have a direct effect on $\mathrm{CD} 4{ }^{+} \mathrm{CD} 25^{+} \mathrm{T}$ cells. With the above results in mind, we came to the conclusion that unlike androgens, the effect of estrogens on regulatory $\mathrm{T}$ cells was less clearly defined. 
A
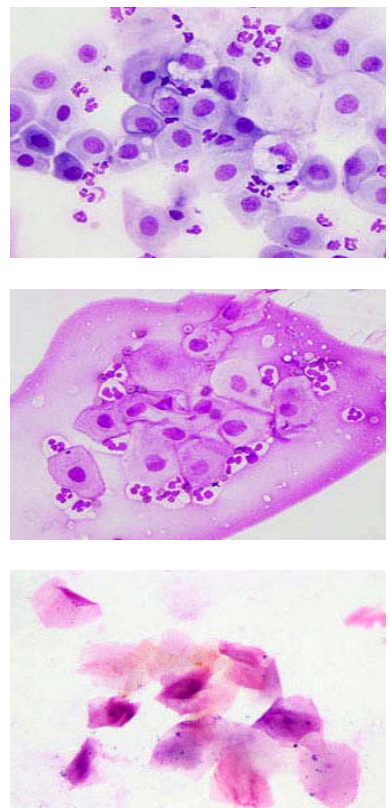

\section{Diestrus}

个 Leucocytes.

$\downarrow$ Cornified epithelial cells.

Moderate nucleated epithelial cells.

\section{Proestrus}

$\uparrow$ Nucleated epithelial cells.

$\downarrow$ Leucocytes.

Moderate cornified

epithelial cells.

\section{Estrus}

$\uparrow$ Nucleated cornified epithelial cells.

B

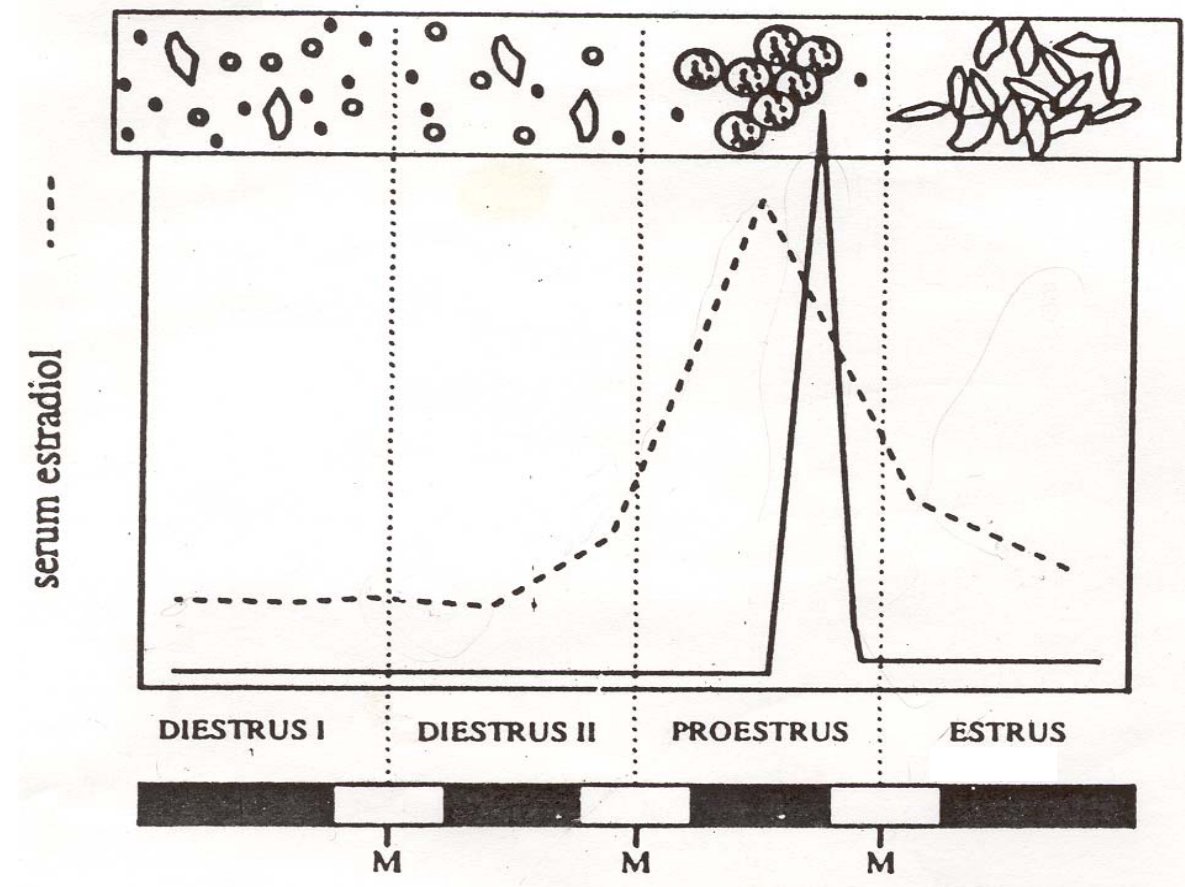

Figure 26. Diestrus, estrus and proestrus stages of the estrous cycle as observed under the microscope (A) and reflect changes in estrogen levels that occur during each stage (B). During the diestrus stage, estrogen levels are low, then the levels increase and peak during the proestrus stage, then decrease to low levels during the estrus stage (B). These fluctuations in estrogen hormone levels correspond to the emergence or disappearance of characteristic cells as observed in (A). 
A
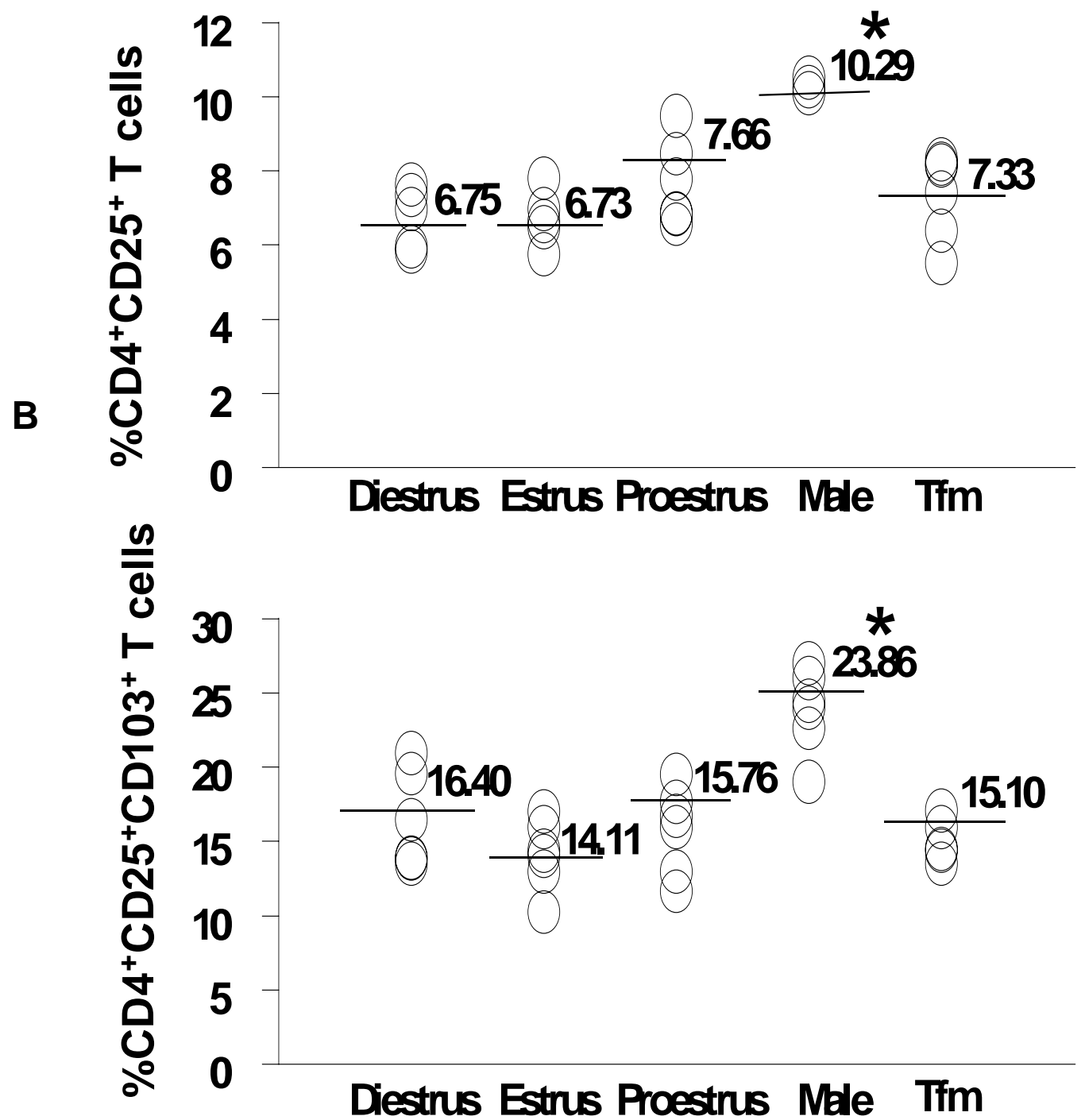

Figure 27. The percentages of $\mathrm{CD} 4^{+} \mathrm{CD} 25^{+}$and $\mathrm{CD} 4^{+} \mathrm{CD} 25^{+} \mathrm{CD} 103^{+}$regulatory

$\mathrm{T}$ cells are not significantly different between the diestrus, proestrus and estrus stages.

Lymph node cells from individual female mice at various stages of the estrous cycle or male mice, were labeled with anti-CD4, anti-CD25 and anti-CD103 antibodies, then analyzed by $\mathrm{FACS}^{\circledR}$ to determine the percentage of $\mathrm{CD} 4{ }^{+} \mathrm{CD} 25^{+}(\mathrm{A})$ and $\mathrm{CD} 4{ }^{+} \mathrm{CD} 25^{+} \mathrm{CD} 103^{+}(\mathrm{B})$ regulatory $\mathrm{T}$ cells. An * indicates a significant difference at $\mathrm{p}<0.05$. 


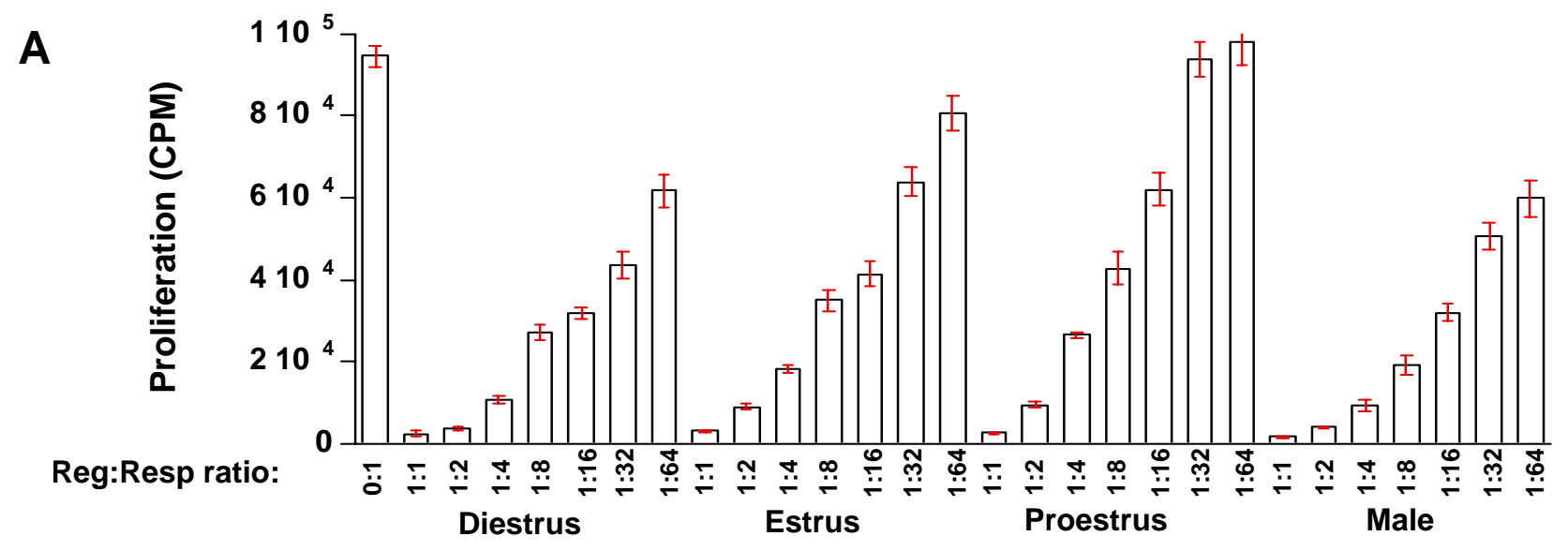

B
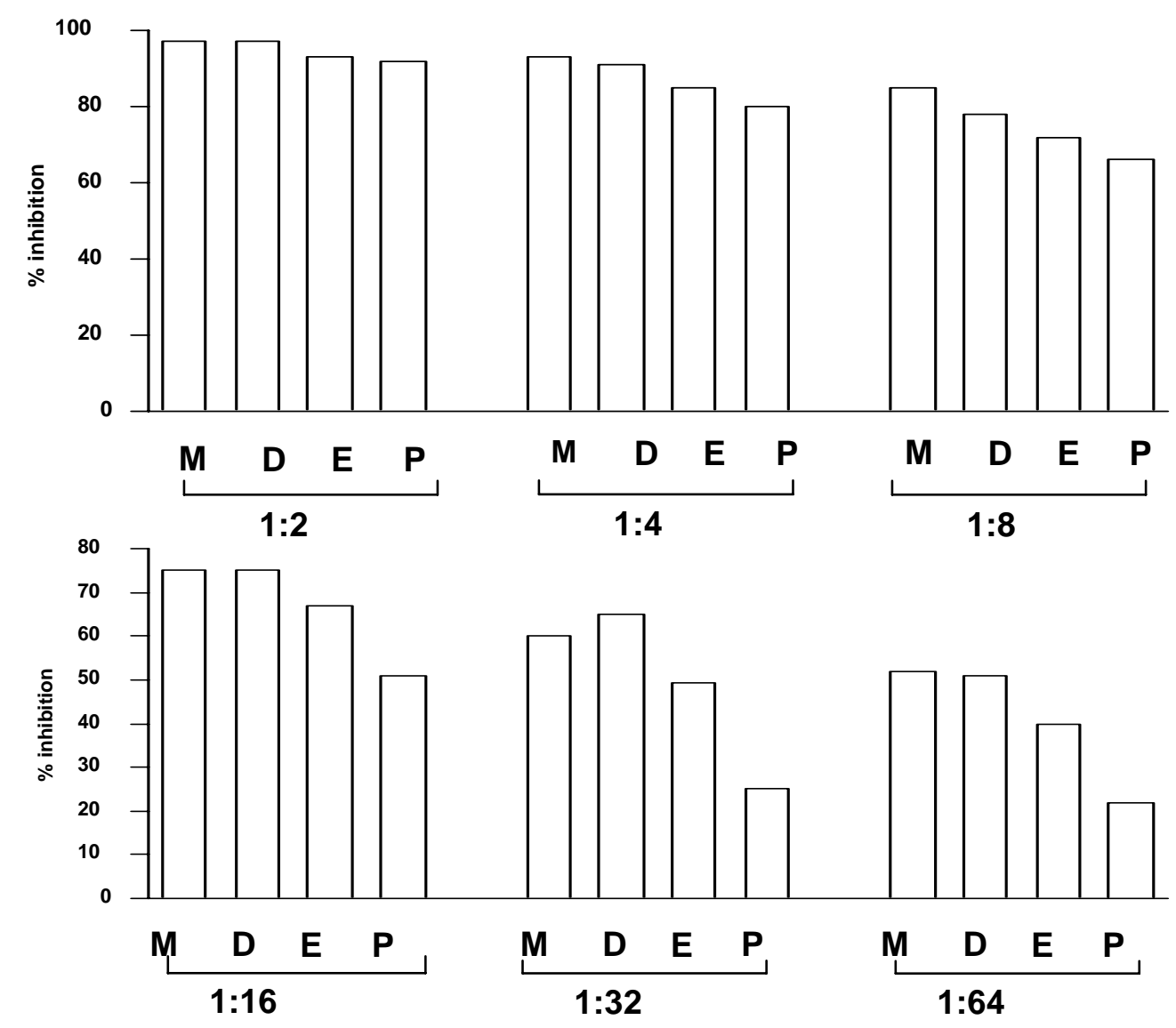

Figure 28. $\mathrm{CD} 4{ }^{+} \mathrm{CD} 25^{+}$regulatory $\mathrm{T}$ cells from $\mathrm{C} 57 \mathrm{BL} / 6$ female mice in proestrus are slightly less effective than those from male mice at regulating proliferation of responder cells. The suppressive ability of varying ratios of $\mathrm{CD} 4{ }^{+} \mathrm{CD} 25^{+}$cells harvested from mice at each stage of the estrous cycle was tested in vitro (A) and the percentage inhibition of suppression calculated (B). $\mathrm{CD} 4{ }^{+} \mathrm{CD} 25^{+} \mathrm{T}$ cells harvested from female mice at the diestrus, estrus and proestrus stages, or from male mice were cocultured with $\mathrm{CD} 4^{+} \mathrm{CD} 25^{-}$ responder T cells, irradiated spleen cells (APC) and anti-CD3 antibody for 3 days, and tested for their suppressive ability. 


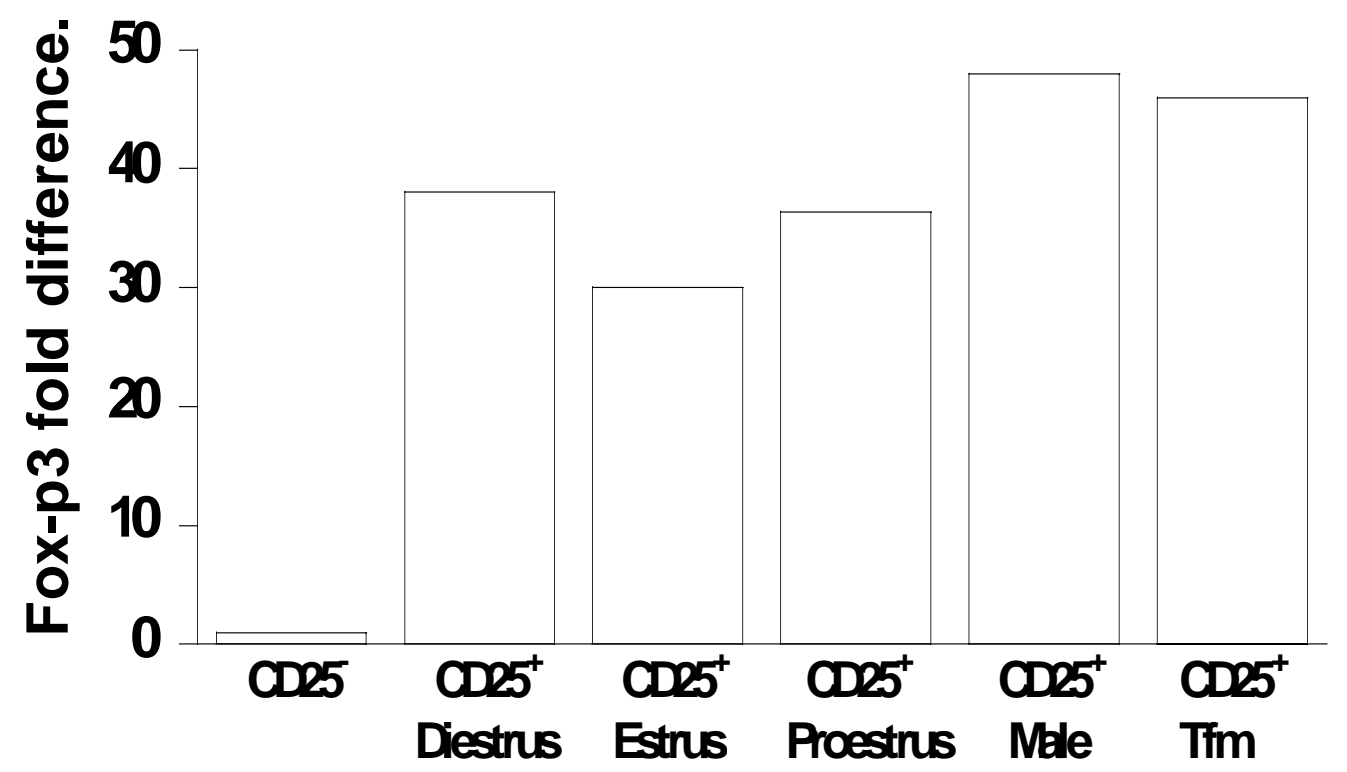

Figure 29. There were no significant differences in Foxp3 expression by $\mathrm{CD} 4{ }^{+} \mathrm{CD} 25^{+} \mathrm{T}$ cells from diestrus, estrus or proestrus females, or males. $\mathrm{CD} 4{ }^{+} \mathrm{CD} 25^{+} \mathrm{T}$ cells from C57BL/6 females at various stages of the estrous cycle, and male adult mice were sorted to $>98 \%$ purity, mRNA extracted and the androgen receptor mRNA detected by real time-PCR. mRNA from $\mathrm{CD} 4^{+} \mathrm{CD} 25^{-} \mathrm{T}$ cells was used as negative control. 

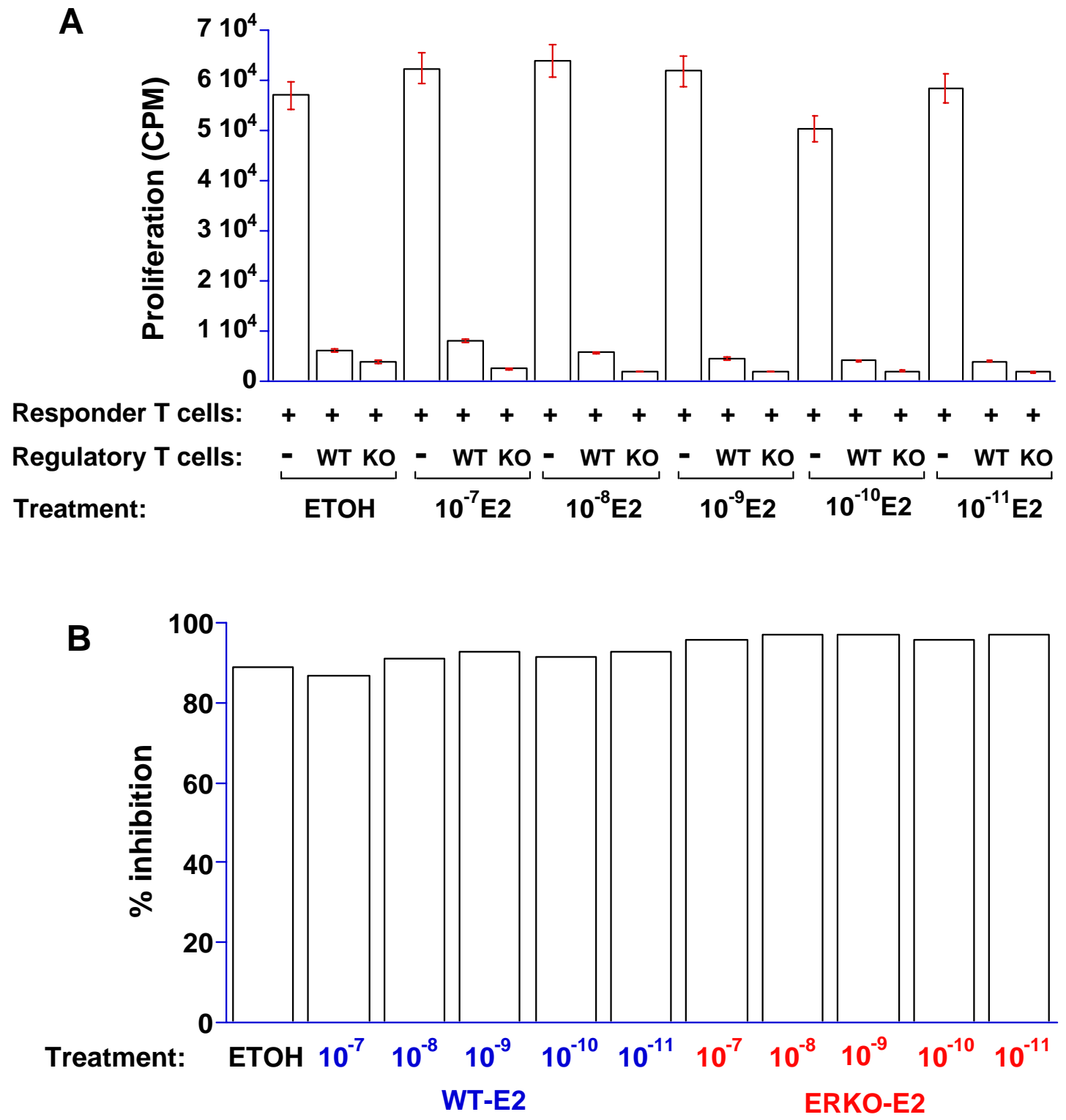

Figure 30. Estradiol does not have a direct effect on $\mathrm{CD} 4{ }^{+} \mathrm{CD} 25^{+} \mathrm{T}$ cells in vitro. Purified female wild-type or estrogen receptor knockout $\mathrm{CD} 4^{+} \mathrm{CD} 25^{+} \mathrm{T}$ cells were analyzed for their ability to regulate $\mathrm{CD} 4^{+} \mathrm{CD} 25^{-} \mathrm{T}$ cells in the presence of varying concentrations of estradiol or vehicle (ethanol) control (A) and the percentage inhibition of suppression calculated (B). A constant number of $\mathrm{CD} 4{ }^{+} \mathrm{CD} 25^{+}$T cells from female wild-type or estrogen receptor knockout mice was co-cultured with $\mathrm{CD} 4^{+} \mathrm{CD} 25^{-} \mathrm{T}$ cells in the presence of irradiated spleen cells (APC), anti-CD3 and increasing doses of estradiol, and evaluated for the degree of proliferation 


\section{SPECIFIC AIM III}

\section{Assessment of $\mathrm{CD}^{+} \mathrm{CD} 25^{+} \mathrm{T}$ cells and the effects of androgens in systemic lupus erythematosus.}

The NZB x NZW mouse model develops a spontaneous SLE that is characterized by accelerated glomerulonephritis that is due to the deposition of immune complexes, including anti-DNA immunoglobulin. Since the disease in NZB x NZW mice resembles human lupus very closely, in both the immunological features of the disease as well as the increased incidence of disease in females, this model may be useful for the identification of the critical factors that contribute to the development of human SLE.

Interestingly, treatment with androgens has been found to decrease SLE in experimental models, while pregnancy and estrogens exacerbate disease (182-185). These data strongly suggest that steroids have a direct effect on disease incidence and severity. Studies have shown that the levels of $\mathrm{CD} 4{ }^{+} \mathrm{CD} 25^{+} \mathrm{T}$ cells in the peripheral blood of SLE patients are decreased compared to normal individuals (172). Such studies suggest that $\mathrm{CD} 4^{+} \mathrm{CD} 25^{+}$cells may play a role in the pathogenesis of SLE. The following study was designed to determine the relationship between $\mathrm{CD} 4{ }^{+} \mathrm{CD} 25^{+}$ regulatory T cells and androgens in NZB x NZW mice and the development of SLE. 


\section{Analysis of numbers, function and phenotype of $\mathrm{CD}^{+} \mathrm{CD} 25^{+}$regulatory $\mathrm{T}$ cells from female and male NZB x NZW mice.}

Despite the number of studies performed, there still remains a paucity of information about the role of $\mathrm{CD} 4{ }^{+} \mathrm{CD} 25^{+}$regulatory $\mathrm{T}$ cells in the etiology of autoimmune diseases like SLE. In the following experiments, we aimed to compare the percentage, function and phenotype of $\mathrm{CD} 4{ }^{+} \mathrm{CD} 25^{+}$regulatory $\mathrm{T}$ cells in the lymphoid tissues of female NZB x NZW mice that spontaneously develop lupus-like disease, and disease-resistant male NZB x NZW mice. We examined female versus male NZB x NZW mice between the ages of 8-28 weeks for the percentage of $\mathrm{CD} 4^{+} \mathrm{CD} 25^{+} \mathrm{T}$ cells. First, we evaluated $\mathrm{CD} 4{ }^{+} \mathrm{CD} 25^{+}$cells in blood at 8 and 12 weeks of age and found no differences between female and male NZB x NZW mice (Table 11b). However, at 9, 16 or 18 weeks of age, the percentages of $\mathrm{CD} 4^{+} \mathrm{CD} 25^{+}$cells in the lymph node of female mice were significantly lower (or tended to be lower) than that found in males, while at 28 weeks, there were no significant differences in the percentage of $\mathrm{CD} 4{ }^{+} \mathrm{CD} 25^{+} \mathrm{T}$ cells between females and males (Figure 31, Table 11a).

The integrin, CD103 is highly expressed by a significant percentage of $\mathrm{CD} 4^{+} \mathrm{CD} 25^{+} \mathrm{T}$ cells and appears to identify a sub-population of $\mathrm{CD} 4^{+} \mathrm{CD} 25^{+}$regulatory cells that exhibit more potent regulatory function in vitro, and aids in preferential trafficking to sites of inflammation $(186,187)$. In the following experiments, we investigated the expression of $\mathrm{CD} 103$ by $\mathrm{CD} 4^{+} \mathrm{CD} 25^{+} \mathrm{T}$ cells in female and male NZB $\mathrm{x}$ NZW mice. In the blood, we found at 8 and 12 weeks that female mice already had significantly fewer $\mathrm{CD} 4{ }^{+} \mathrm{CD} 25^{+}$cells that expressed $\mathrm{CD} 103$ (Figure 32 , Table 12b). At 9 , 16 and 18 weeks, a significantly lower percentage (or a similar trend) of lymph node 
$\mathrm{CD} 4{ }^{+} \mathrm{CD} 25^{+}$cells from non-sick female mice expressed CD103 compared with non-sick male mice (Figure 33A, Table 12a). At 28 weeks, non-sick female $\mathrm{CD} 4^{+} \mathrm{CD} 25^{+}$cells expressed a significantly lower percentage of CD103, than non-sick male mice, and sick female $\mathrm{CD} 4^{+} \mathrm{CD} 25^{+}$cells were observed to express a significantly higher percentage of CD103 compared with non-sick female or male mice (Figure 33A, Table 12a). At 28 weeks, both sick and non-sick female $\mathrm{CD} 4{ }^{+} \mathrm{CD} 25^{+}$cells generally expressed a significantly lower percentage of CD62L, than non-sick male mice (Figure 33B, Table 13). Lower levels of $\mathrm{CD} 62 \mathrm{~L}$ expression by $\mathrm{CD} 4^{+} \mathrm{CD} 25^{+}$cells from 28 week-old female NZB x NZW mice suggest that these cells may actually be activated T cells, and not regulatory T cells. Regarding the expression of CTLA-4 and Foxp3 by $\mathrm{CD} 4{ }^{+} \mathrm{CD} 25^{+}$ cells at 28 weeks, we did not find any significant differences in the percentage of expression of either of these molecules between females and males (Table 13). We also did not find any significant differences in the mean intensity of expression of CD62L, CD103, CTLA- 4 and Foxp 3 by $\mathrm{CD} 4{ }^{+} \mathrm{CD} 25^{+}$cells from female and male mice (data not shown).

Paradoxically, in general, the percentage of $\mathrm{CD}^{+} \mathrm{CD} 25^{+}$in the thymus, was significantly higher in the females than in the male mice; likewise, the percentage of $\mathrm{CD}^{+} \mathrm{CD} 25^{+} \mathrm{CD}_{103^{+}} \mathrm{T}$ cells was higher in the thymus in females than in males (Table 14). These data suggest that the decrease in $\mathrm{CD} 4^{+} \mathrm{CD} 25^{+}$cells found in the periphery may not be due to failure of the thymus to produce $\mathrm{CD} 4^{+} \mathrm{CD} 25^{+}$cells.

In these experiments, we also assessed the absolute numbers of $\mathrm{CD} 4^{+} \mathrm{CD} 25^{+}$or $\mathrm{CD}^{+} \mathrm{CD} 25^{+} \mathrm{CD} 103^{+} \mathrm{T}$ cells in NZB x NZW female versus male mice. In correlation with the percentages, in the majority of experiments at 9,16 , or 18 weeks, the absolute 
number of lymph node $\mathrm{CD} 4^{+} \mathrm{CD} 25^{+}$from non-sick females was significantly lower than that in non-sick male mice, while at 28 weeks, the absolute number of lymph node $\mathrm{CD} 4{ }^{+} \mathrm{CD} 25^{+}$from sick females was significantly higher than that found in non-sick female or male mice (Table 15a). Similarly, in the majority of experiments at 9, 16, or 18 weeks, the absolute number of lymph node $\mathrm{CD} 4^{+} \mathrm{CD} 25^{+} \mathrm{CD} 103^{+}$from non-sick females was significantly lower than that in non-sick male mice, while at 28 weeks, the absolute number of lymph node $\mathrm{CD} 4^{+} \mathrm{CD} 25^{+}$from sick females was significantly higher than that found in non-sick female or male mice (Table 15b).

Assays to compare regulatory function of $\mathrm{CD} 4{ }^{+} \mathrm{CD} 25^{+}$and $\mathrm{CD} 4^{+} \mathrm{CD} 25^{+} \mathrm{CD} 103^{+}$cells from female versus male NZB x NZW mice were also performed to determine whether there are differences in regulatory activity. In both experiments at 9 weeks, male $\mathrm{CD} 4^{+} \mathrm{CD} 25^{+}$cells were not significantly better than female cells in suppressing responder $\mathrm{CD}^{+} \mathrm{CD}^{-} 5^{-}$(Fig 34A, Table 16a). However, in the majority of experiments at 9, 16 or 28 weeks, male $\mathrm{CD} 4^{+} \mathrm{CD} 25^{+} \mathrm{CD} 103^{+}$regulatory $\mathrm{T}$ cells were better than their female counterparts in suppressing in vitro proliferation at ratios of 1:1, 1:2, 1:4 and 1:8 (Figure 34B, Table 16b). These results indicated that unlike $\mathrm{CD} 4{ }^{+} \mathrm{CD} 25^{+} \mathrm{T}$ cells, male NZB x NZW CD $4^{+} \mathrm{CD} 25^{+} \mathrm{CD} 103^{+} \mathrm{T}$ cells were better than females in suppressing responder $\mathrm{CD} 4^{+} \mathrm{CD} 25^{-} \mathrm{T}$ cells.

Overall, the data described above were generally indicative of the fact that female NZB x NZW mice had significantly lower levels of $\mathrm{CD} 4{ }^{+} \mathrm{CD} 25^{+} \mathrm{T}$ cells, compared with male mice. Similarly, a smaller percentage of $\mathrm{CD} 4^{+} \mathrm{CD} 25^{+} \mathrm{T}$ cells from female mice expressed the CD103 phenotype, compared with male mice. Furthermore, although sick female mice at 28 weeks generally had significantly more $\mathrm{CD} 4^{+} \mathrm{CD} 25^{+}$or 
$\mathrm{CD} 4^{+} \mathrm{CD} 25^{+} \mathrm{CD} 103^{+}$cells in the lymph nodes, the $\mathrm{CD} 4^{+} \mathrm{CD} 25^{+}$cells generally expressed lower levels of CD62L, suggesting that these cells may represent an activated phenotype. The results of the proliferation assays indicated that unlike unfractionated $\mathrm{CD} 4{ }^{+} \mathrm{CD} 25^{+} \mathrm{T}$ cells, where little or no differences in suppression were found between NZB x NZW females and males, the $\mathrm{CD} 4{ }^{+} \mathrm{CD} 25^{+} \mathrm{CD} 103^{+}$from males suppressed better than those from females, suggesting that males have more potent and greater numbers of $\mathrm{CD}^{+} \mathrm{CD} 25^{+} \mathrm{CD} 103^{+}$cells which by virtue of the CD103 surface marker can differentially traffic to sites of inflammation. Taken together, these data suggest a defect in the $\mathrm{CD}_{103}{ }^{+}$subset of $\mathrm{CD} 4{ }^{+} \mathrm{CD} 25^{+}$regulatory cells in female NZB x NZW mice could contribute to the increased incidence of disease in females.

\section{Assess the effects of androgens on $\mathrm{CD}^{+} \mathrm{CD} 25^{+} \mathrm{T}$ cells in $\mathrm{NZB} \times \mathrm{NZW}$ mice and correlate these effects with SLE disease regression or progression.}

In recent years, the potential role of androgens in the prevention/cure of SLE has been investigated with results that generally suggest that androgens may protect the disease. In some of such studies the role of testosterone in the treatment of SLE was emphasized, wherein the administration of various forms of the steroid alleviated or modified the course of SLE in both females and males $(87,117,153-155,188)$.

\section{a). Effect of the absence of androgens in male NZB $x$ NZW mice.}

In these experiments, male mice were castrated at 3 weeks of age to determine the effects of the absence of androgens on $\mathrm{CD}^{+} \mathrm{CD} 25^{+}$numbers and function. At 8 and 12 weeks, blood from the castrated and intact male mice was evaluated by FACS ${ }^{\circledR}$, to quantify the levels of $\mathrm{CD} 4{ }^{+} \mathrm{CD} 25^{+}$and $\mathrm{CD} 4{ }^{+} \mathrm{CD} 25^{+} \mathrm{CD} 103^{+}$cells. Significant differences in the 
levels of $\mathrm{CD} 4^{+} \mathrm{CD} 25^{+} \mathrm{CD} 103^{+}$, but not $\mathrm{CD} 4^{+} \mathrm{CD} 25^{+}$cells were generally found in the blood of castrated males compared with intact male mice (Tables 17a and 17b). We also did not find any significant differences in the levels of $\mathrm{CD} 4^{+} \mathrm{CD} 25^{+}$and $\mathrm{CD} 4^{+} \mathrm{CD} 25^{+} \mathrm{CD} 103^{+}$cells by castrated males versus intact females treated with vehiclepellet (Tables 17a and 17b). The levels of $\mathrm{CD} 4^{+} \mathrm{CD} 25^{+} \mathrm{CD} 103^{+}$, but not $\mathrm{CD} 4^{+} \mathrm{CD} 25^{+}$ cells in intact male mice were generally significantly higher than those in intact females treated with vehicle pellet (Tables 17a and 17b). We also performed proliferation assays to compare the regulatory function of $\mathrm{CD} 4{ }^{+} \mathrm{CD} 25^{+} \mathrm{CD} 103^{+}$cells from intact versus castrated males. Our results indicated that $\mathrm{CD} 4^{+} \mathrm{CD} 25^{+} \mathrm{CD} 103^{+}$cells from intact male mice did not suppress the proliferation of $\mathrm{CD} 4^{+} \mathrm{CD} 25^{-}$responder cells significantly better than those from castrated mice (Figure 35A, Table 18).

After a period of 24 weeks, lymph nodes from the mice were collected and analyzed for $\mathrm{CD} 4{ }^{+} \mathrm{CD} 25^{+}$regulatory cell numbers, phenotype and function. Our results in one experiment indicated that although there were no differences between the percentage of $\mathrm{CD}^{+} \mathrm{CD} 25^{+}$cells in castrated and intact males (Figure 36A, Table 19a), on the other hand, castrated males had significantly decreased percentages of $\mathrm{CD} 4^{+} \mathrm{CD} 25^{+} \mathrm{CD} 103^{+}$cells compared to intact males (Figure $36 \mathrm{~B}$, Table 19b). The absolute numbers of both $\mathrm{CD} 4^{+} \mathrm{CD} 25^{+}$and $\mathrm{CD} 4^{+} \mathrm{CD} 25^{+} \mathrm{CD} 103^{+}$cells in castrated males and females treated with placebo pellet were significantly decreased compared to intact males (Table 20).

The overall summary of these results is that the absence of androgens could lead to a reduction in the percentages of $\mathrm{CD} 4{ }^{+} \mathrm{CD} 25^{+} \mathrm{CD} 103^{+}$cells in male mice, as was observed when levels in castrated mice either dropped to lower levels compared to those 
in intact male mice, or were comparable to levels in intact females that were treated with vehicle pellet.

To correlate number of $\mathrm{CD} 4^{+} \mathrm{CD} 25^{+}$cells and disease development at $12-20$ weeks of age, serum samples from castrated or intact NZB x NZW male mice were collected monthly and evaluated by ELISA for the appearance of IgG antibodies to dsDNA in serum in order to evaluate the progress of disease. In general, the anti-dsDNA levels were higher in females than males for all ages evaluated. Interestingly, our results indicated that castrated male mice had higher levels of serum antibodies to dsDNA than intact male controls that were comparable to those found in females (Figure $37)$.

\section{b). Effect of androgen treatment of female NZB x NZW mice.}

In the following experiments, female NZB x NZW mice were treated with androgen pellets or vehicle pellets as control and tested for the influence of androgens $\mathrm{CD} 4^{+} \mathrm{CD} 25^{+}$ cells in female mice. At 8 and 12 weeks of age, blood from these mice was evaluated by FACS for the levels of $\mathrm{CD} 4{ }^{+} \mathrm{CD} 25^{+}$and $\mathrm{CD} 4^{+} \mathrm{CD} 25^{+} \mathrm{CD} 103^{+}$cells. Androgen pellettreated females exhibited significantly higher levels of $\mathrm{CD} 4^{+} \mathrm{CD} 25^{+}$cells compared with vehicle-treated female controls, and the levels of $\mathrm{CD} 4{ }^{+} \mathrm{CD} 25^{+}$cells in androgen pellettreated females was generally comparable to levels in intact male controls (Table 17a). The percentage of $\mathrm{CD} 4^{+} \mathrm{CD} 25^{+}$cells in androgen-treated females that expressed $\mathrm{CD} 103^{+}$ was generally comparable to the percentage in intact males, but was generally not significantly higher than the percentage in placebo-treated control females (Table 17b). 
At 24 weeks of age, lymph nodes from the mice were collected and analyzed for $\mathrm{CD} 4{ }^{+} \mathrm{CD} 25^{+}$regulatory cell numbers, phenotype and function. In both experiments, the results indicated that although the percentages of $\mathrm{CD} 4{ }^{+} \mathrm{CD} 25^{+}$and $\mathrm{CD} 4^{+} \mathrm{CD} 25^{+} \mathrm{CD} 103^{+}$ cells in androgen-treated female mice was not significantly greater than in placebotreated females, they were generally comparable to the percentages in intact male mice (Table 19a \& b). In both experiments, the results also indicated that absolute numbers of $\mathrm{CD} 4^{+} \mathrm{CD} 25^{+}$and $\mathrm{CD} 4^{+} \mathrm{CD} 25^{+} \mathrm{CD} 103^{+}$cells in androgen-treated female mice were significantly greater than in placebo-treated females, and were generally comparable to the percentages in intact male mice (Table 20a \& b). Moreover, $\mathrm{CD} 4^{+} \mathrm{CD} 25^{+} \mathrm{CD} 103^{+}$ cells from intact male or androgen-treated female mice significantly suppressed the proliferation of $\mathrm{CD} 4^{+} \mathrm{CD} 25^{-}$responder cells compared with placebo-treated females (Figure 37B, Table 18). In summary, these results indicate that the administration of androgens to females could lead to an increase in the percentages of $\mathrm{CD} 4^{+} \mathrm{CD} 25^{+}$and $\mathrm{CD}^{+} \mathrm{CD} 25^{+} \mathrm{CD} 103^{+}$cells in female mice.

To correlate number of $\mathrm{CD}^{+} \mathrm{CD} 25^{+}$cells and disease development, serum samples from male, or androgen or placebo-treated female mice were evaluated monthly from 12-24 weeks of age by ELISA for the appearance of IgG antibodies to dsDNA in serum. Our results indicated that androgen-treated female mice had levels of serum antibodies to dsDNA that were comparable to intact male mice, but were significantly lower than in placebo-treated female controls (Figure 38).

In summary, the data obtained with the NZB x NZW mice indicate that female mice may be more susceptible to disease because of a possible defect in the numbers and function of both $\mathrm{CD} 4^{+} \mathrm{CD} 25^{+}$and $\mathrm{CD} 4^{+} \mathrm{CD} 25^{+} \mathrm{CD} 103^{+}$cells. $\mathrm{CD} 4^{+} \mathrm{CD} 25^{+}$cells in male mice 
appear to be generally more numerous and/or more potent in vitro, indicating their potential ability to more effectively prevent SLE in mice. The removal of androgens from males led to an increase in disease as indicated by the increase in antibodies to dsDNA and a coincident reduction in $\mathrm{CD} 4^{+} \mathrm{CD} 25^{+}$cell numbers. On the other hand, the administration of androgens to females inhibited disease progression while at the same time increasing regulatory cell numbers and function. Taken together, these data strongly suggest that sex steroids could affect the incidence and/or severity of disease by affecting the numbers and/or function of regulatory $\mathrm{T}$ cells. 

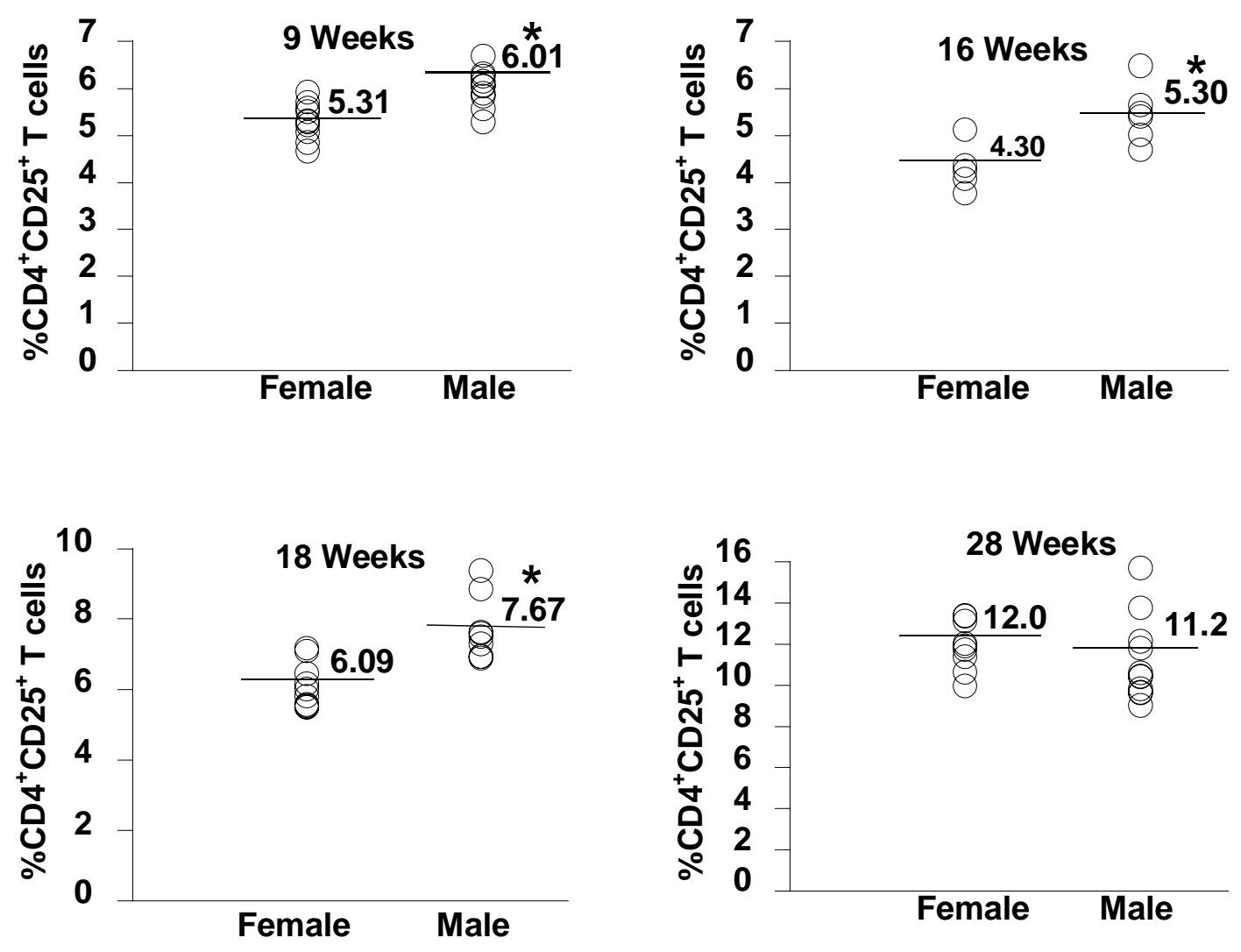

Figure 31. NZB x NZW female mice have significantly fewer $\mathrm{CD} 4^{+} \mathrm{CD} 25^{+}$cells than males at 9,16 and 18 , but not, 28 weeks of age. One million lymph node cells from 9, 16, 18 or 28 week-old female versus male NZB x NZW mice were labeled with anti-CD4 and anti-CD25 antibodies and analyzed by FACS ${ }^{\circledR}$. Stained $C D 4^{+}$T cells were gated and analyzed for the expression of the CD25 surface marker, and the percentage of $\mathrm{CD} 4^{+} \mathrm{T}$ cells that expressed $\mathrm{CD} 25^{+}$were analyzed by student's $\mathrm{t}$ test $(\mathrm{N}=10)$. An $*$ indicates a significant difference at $\mathrm{p}<0.05$. 

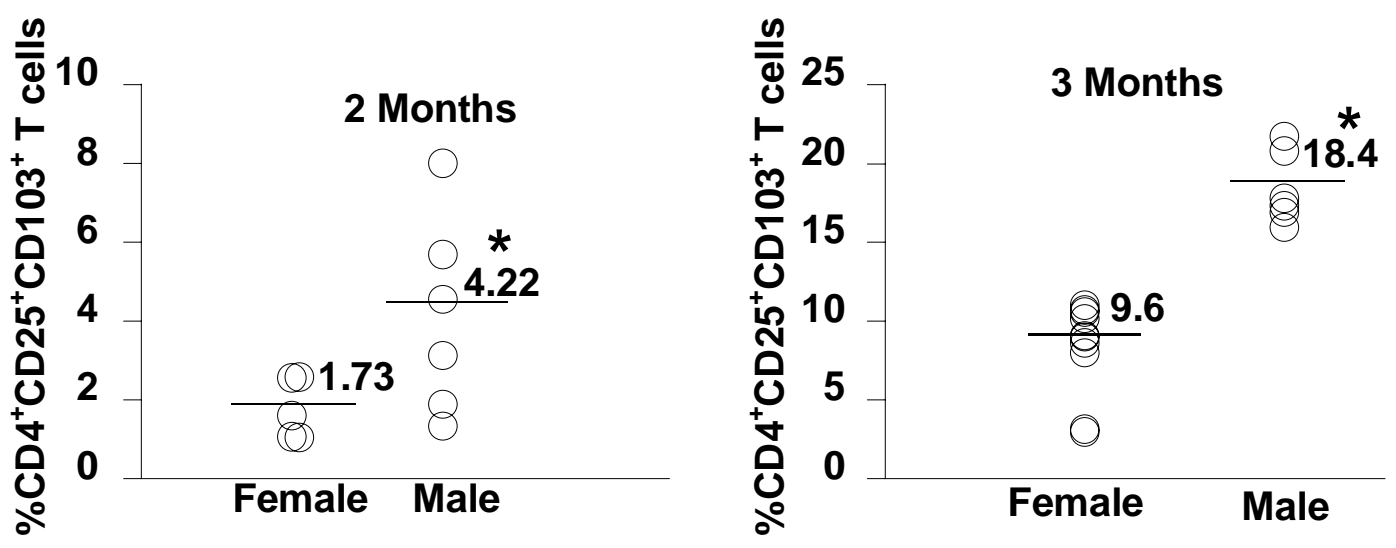

Figure 32. Blood $\mathrm{CD} 4^{+} \mathrm{CD} 25^{+}$cells from female mice express significantly lower CD103 compared with male mice. Blood cells from 8 and 12 week old female versus male NZB x NZW mice were labeled with anti-CD4, anti-CD25 and anti-CD103 antibodies and analyzed by FACS ${ }^{\circledR}$. Stained $\mathrm{CD} 4^{+} \mathrm{CD} 25^{+} \mathrm{T}$ cells were gated and analyzed for the expression of the CD103 surface marker, and the percentage of $\mathrm{CD} 4{ }^{+} \mathrm{CD} 25^{+} \mathrm{T}$ cells that expressedstudent's t test. An * indicates a significant difference at $\mathrm{p}<0.05$ 

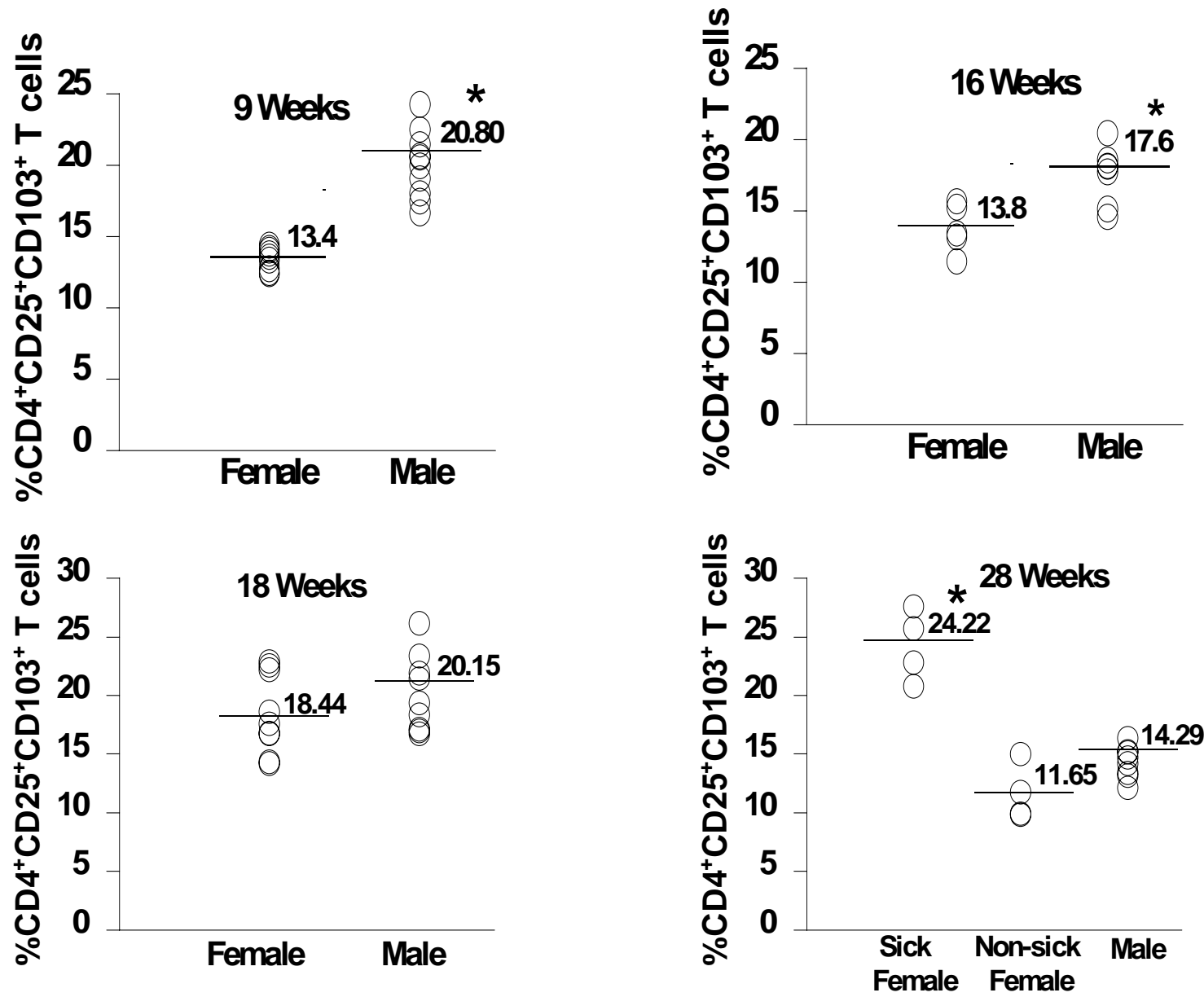

Figure 33. Males have significantly more $\mathrm{CD} 4{ }^{+} \mathrm{CD} 25^{+} \mathrm{CD} 103^{+}$cells at 9 and 16 , but not 28 weeks of age, while females have fewer $\mathrm{CD} 4^{+} \mathrm{CD} 25^{+} \mathrm{CD} 62 \mathrm{~L}^{\text {hi }}$ cells than males at 28 weeks of age. One million lymph node cells from $9,16,18$ or 28 week female versus male NZB x NZW mice were labeled with anti-CD4, anti-CD25, anti-CD62L and anti-CD103 antibodies and analyzed by $F A C S^{\circledR}$. Stained $C D 4^{+} \mathrm{CD} 25^{+} \mathrm{T}$ cells were gated and analyzed for the expression of CD103 or CD62L surface markers, and the percentage of $\mathrm{CD}^{+} \mathrm{CD} 25^{+} \mathrm{T}$ cells that expressed CD103 (A) or CD62L (B), were analyzed by student's $\mathrm{t}$ test. An * indicates a significant difference at $\mathrm{p}<0.05$. 
B

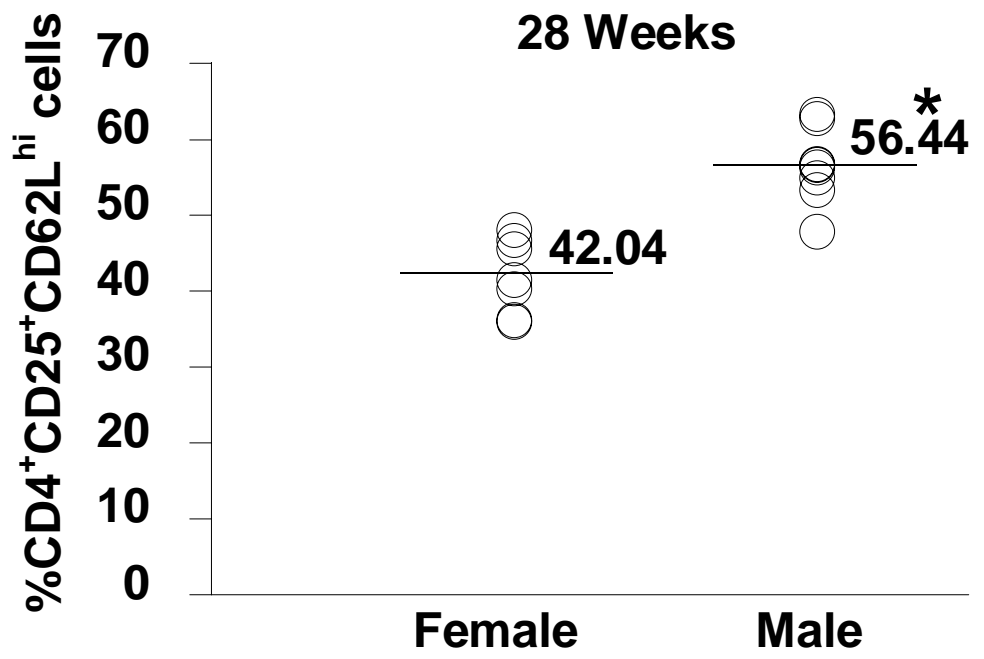


A

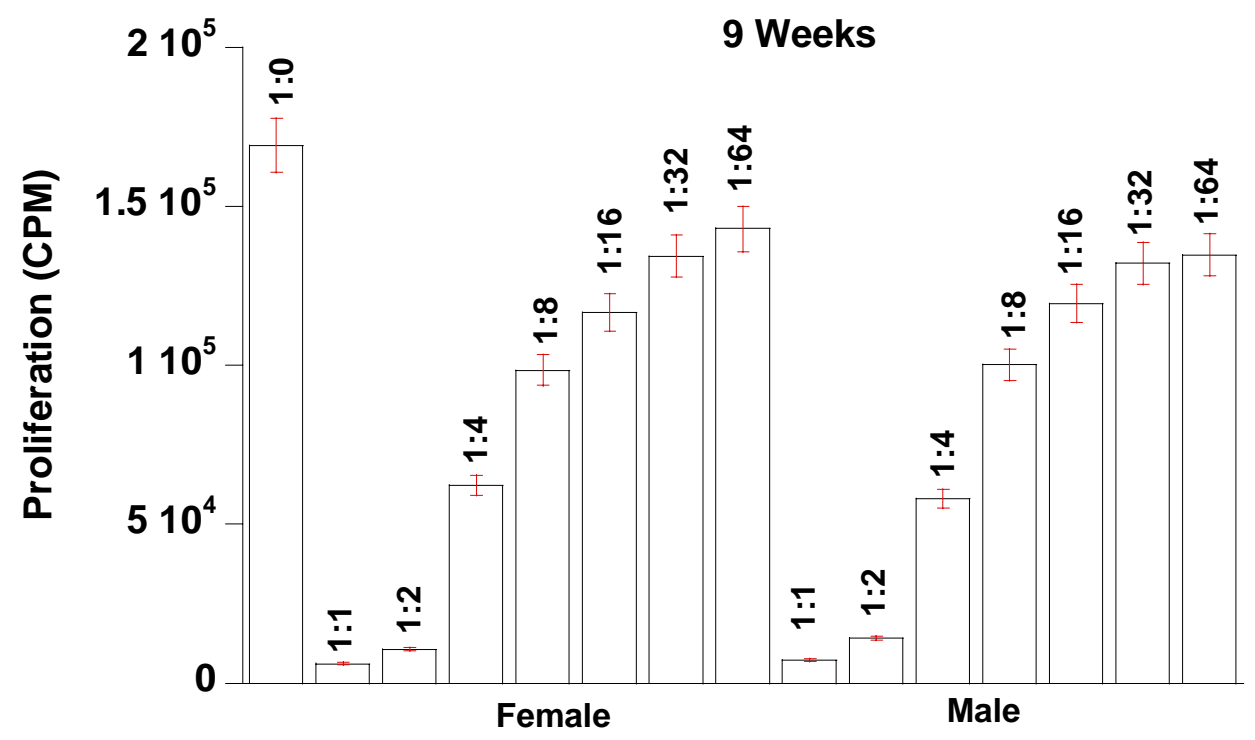

Figure 34. Male NZB x NZW CD $4^{+} \mathrm{CD} 25^{+} \mathrm{CD} 103^{+}$, but not $\mathrm{CD} 4^{+} \mathrm{CD} 25^{+}$, cells suppress $\mathrm{CD} 4^{+} \mathrm{CD} 25^{-}$responder cells significantly better than female $\mathrm{CD} 4^{+} \mathrm{CD} 25^{+} \mathrm{CD} 103^{+}$cells. Female and male $\mathrm{CD} 4^{+} \mathrm{CD} 25^{+}$or $\mathrm{CD} 4^{+} \mathrm{CD} 25^{+} \mathrm{CD} 103^{+} \mathrm{T}$ cells were harvested from NZB $x$ NZW mice of varying ages, and co-cultured with $\mathrm{CD} 4^{+} \mathrm{CD} 25^{-}$responder $\mathrm{T}$ cells in the presence of irradiated spleen cells (APC) and anti-CD3 antibody. $\mathrm{CD} 4{ }^{+} \mathrm{CD} 25^{+}$(A) or $\mathrm{CD}^{+} \mathrm{CD} 25^{+} \mathrm{CD} 103^{+}$(B) regulatory $\mathrm{T}$ cell function was tested at various responder : regulatory cell ratios. An $*$ indicates a significant difference at $\mathrm{p}<0.05$. 
B
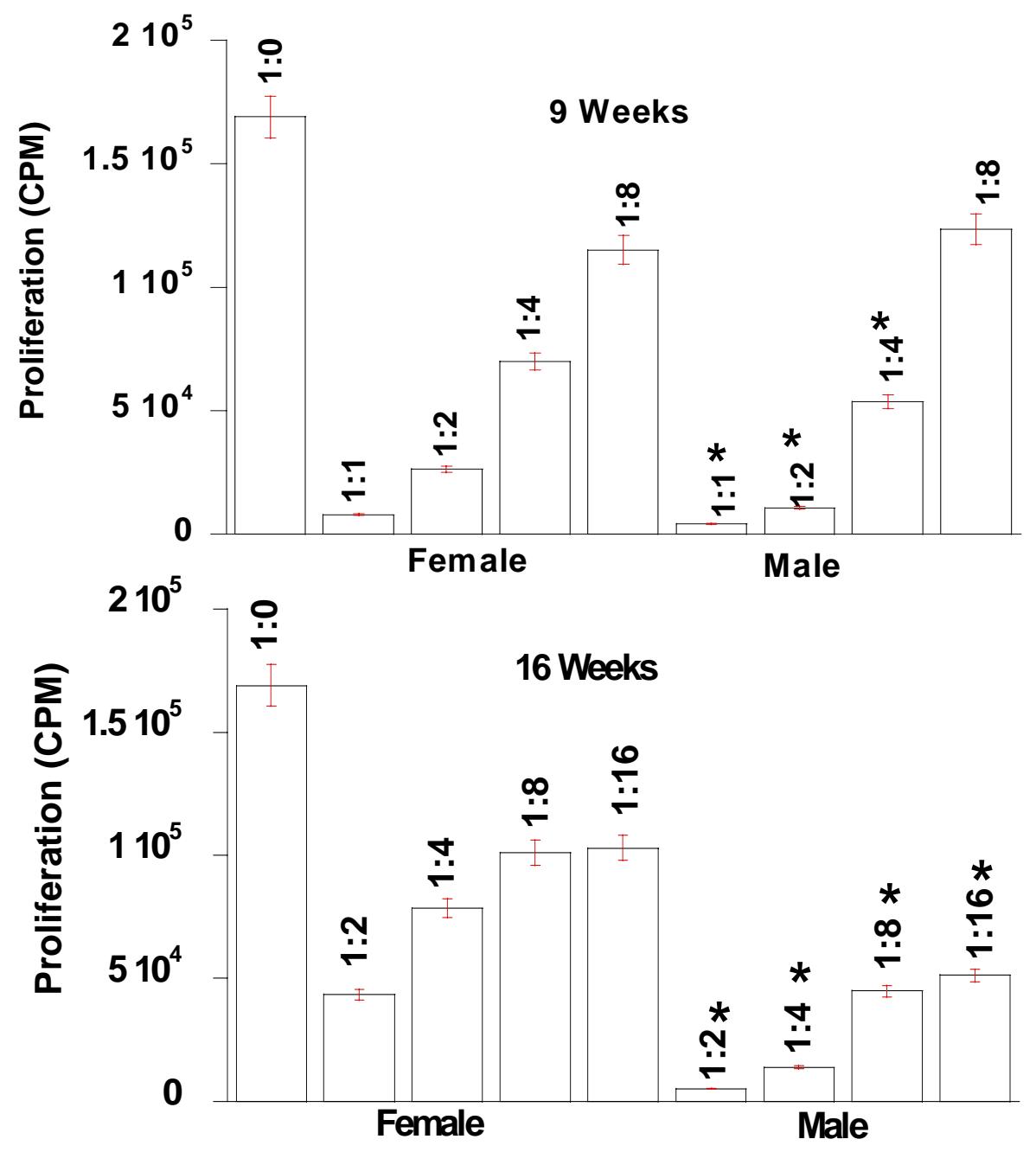

28 Weeks

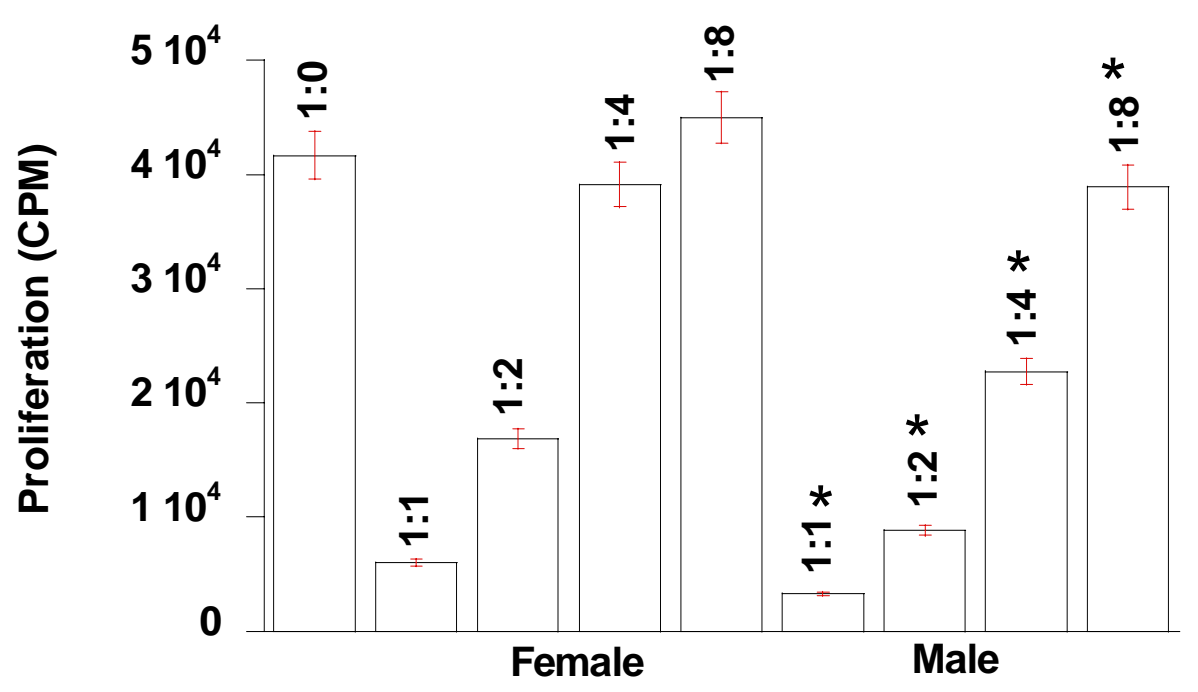




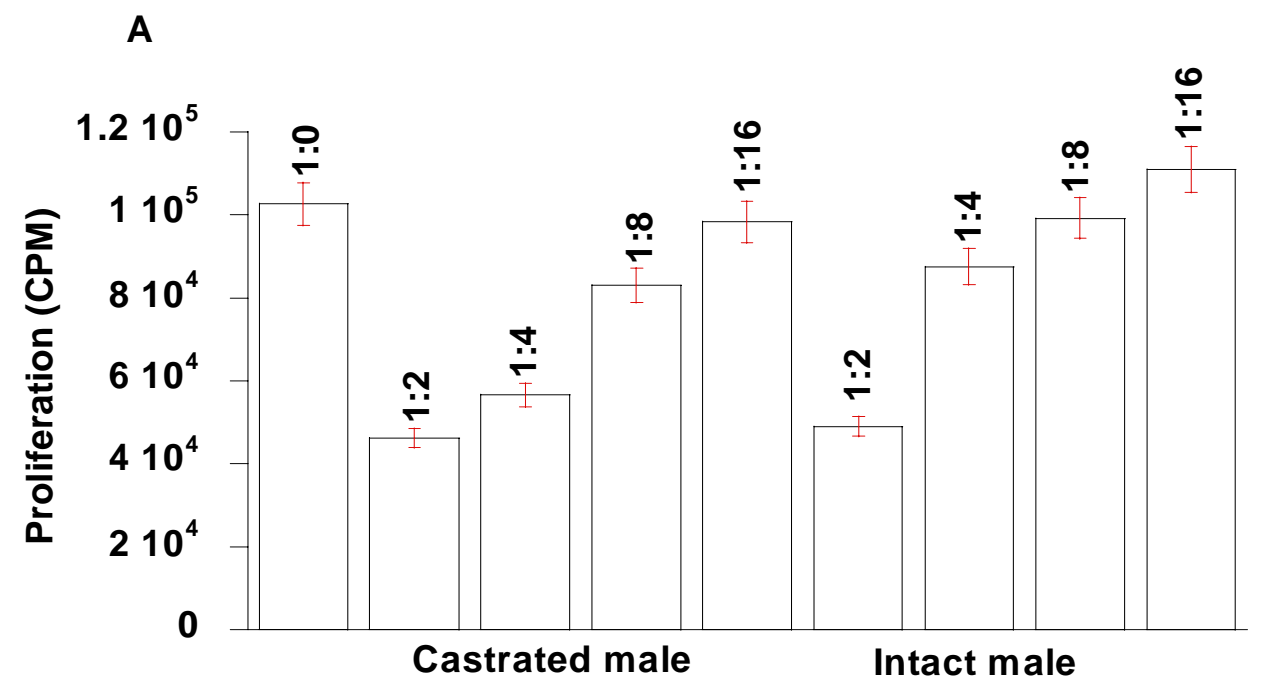

B

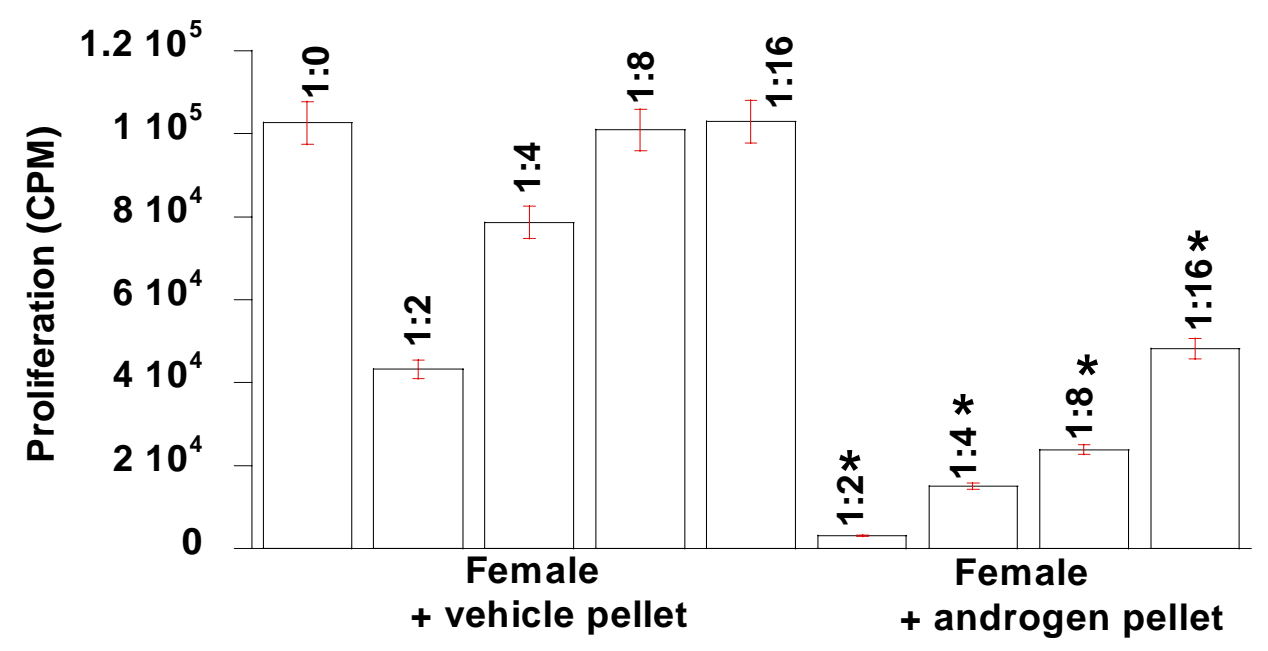

Figure 35. $\mathrm{CD}^{+} \mathrm{CD} 25^{+} \mathrm{CD} 103^{+}$cells from androgen pellet-treated female but not those from intact male mice, suppressed $\mathrm{CD} 4^{+} \mathrm{CD} 25^{-}$cells significantly better than $\mathrm{CD} 4{ }^{+} \mathrm{CD} 25^{+} \mathrm{CD}_{103}{ }^{+}$cells from female vehicle-pellet treated or castrated male mice, respectively. $\mathrm{CD} 4{ }^{+} \mathrm{CD} 25^{+} \mathrm{CD} 103^{+} \mathrm{T}$ cells were harvested from (A) intact or castrated male or (B) vehicle or androgen-treated female NZB x NZW mice, and co-cultured with $\mathrm{CD} 4{ }^{+} \mathrm{CD} 25^{-}$responder $\mathrm{T}$ cells in the presence of irradiated spleen cells (APC) and antiCD3 antibody. $\mathrm{CD} 4{ }^{+} \mathrm{CD} 25^{+} \mathrm{CD} 103^{+}$cell function was tested at various responder : regulatory cell ratios. An $*$ indicates a significant difference at $\mathrm{p}<0.05$. 


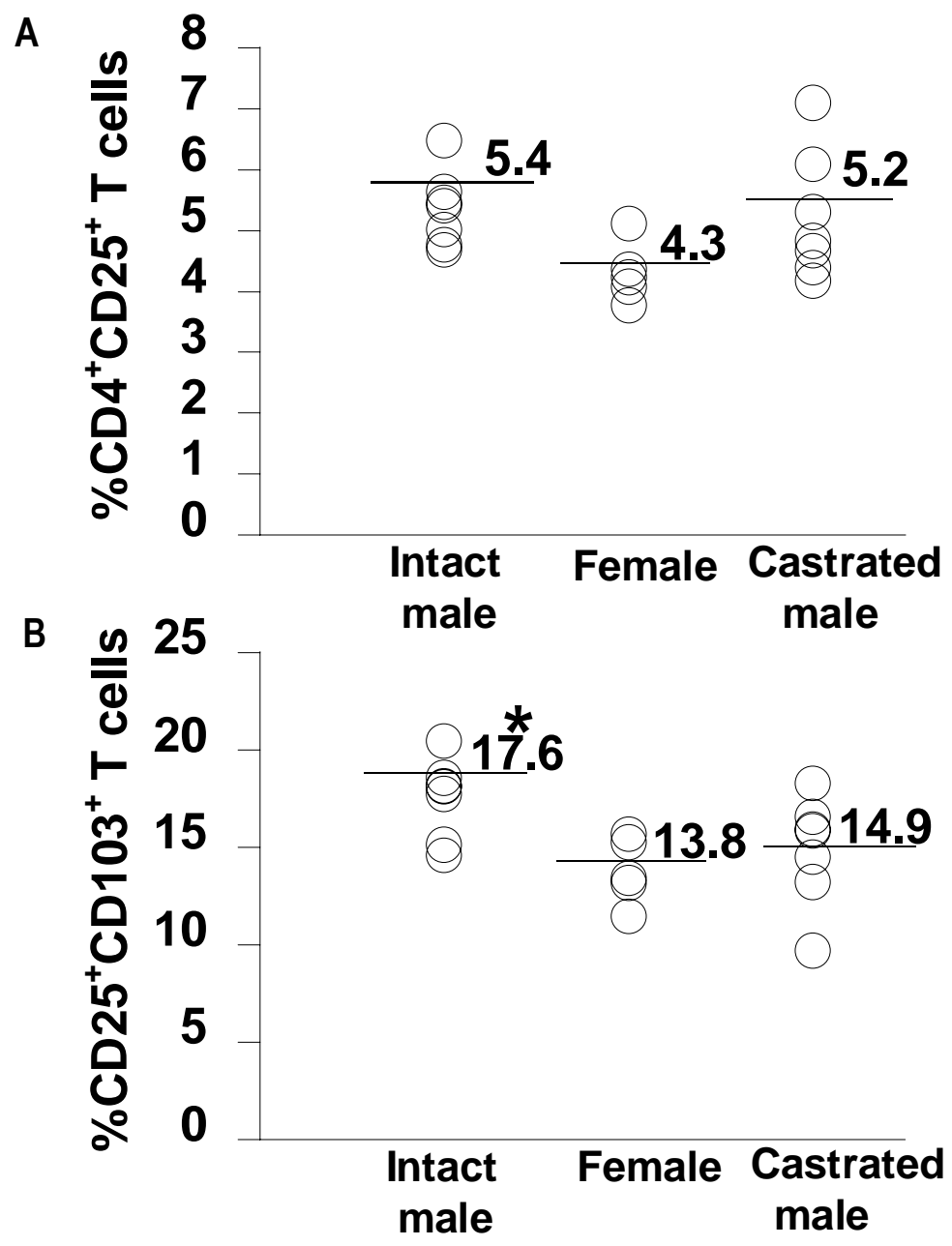

Figure 36. The absence of androgens could lead to a reduction in the percentages of $\mathrm{CD}^{+} \mathrm{CD} 25^{+}$and $\mathrm{CD} 4^{+} \mathrm{CD} 25^{+} \mathrm{CD} 103^{+}$cells in male mice. One million lymph node cells of 24 weeks old treated and untreated female versus male NZB x NZW mice were labeled with anti-CD4, anti-CD25 and anti-CD103 antibodies and analyzed by FACS ${ }^{\circledR}$. Stained $\mathrm{CD} 4^{+}$or $\mathrm{CD} 4^{+} \mathrm{CD} 25^{+} \mathrm{T}$ cells were respectively gated and analyzed for the percentage of $\mathrm{CD} 4^{+} \mathrm{CD} 25^{+}$or $\mathrm{CD} 4^{+} \mathrm{CD} 25^{+} \mathrm{CD} 103^{+}$cells by Student's $\mathrm{t}$ test. An * indicates a significant difference at $\mathrm{p}<0.05$. 

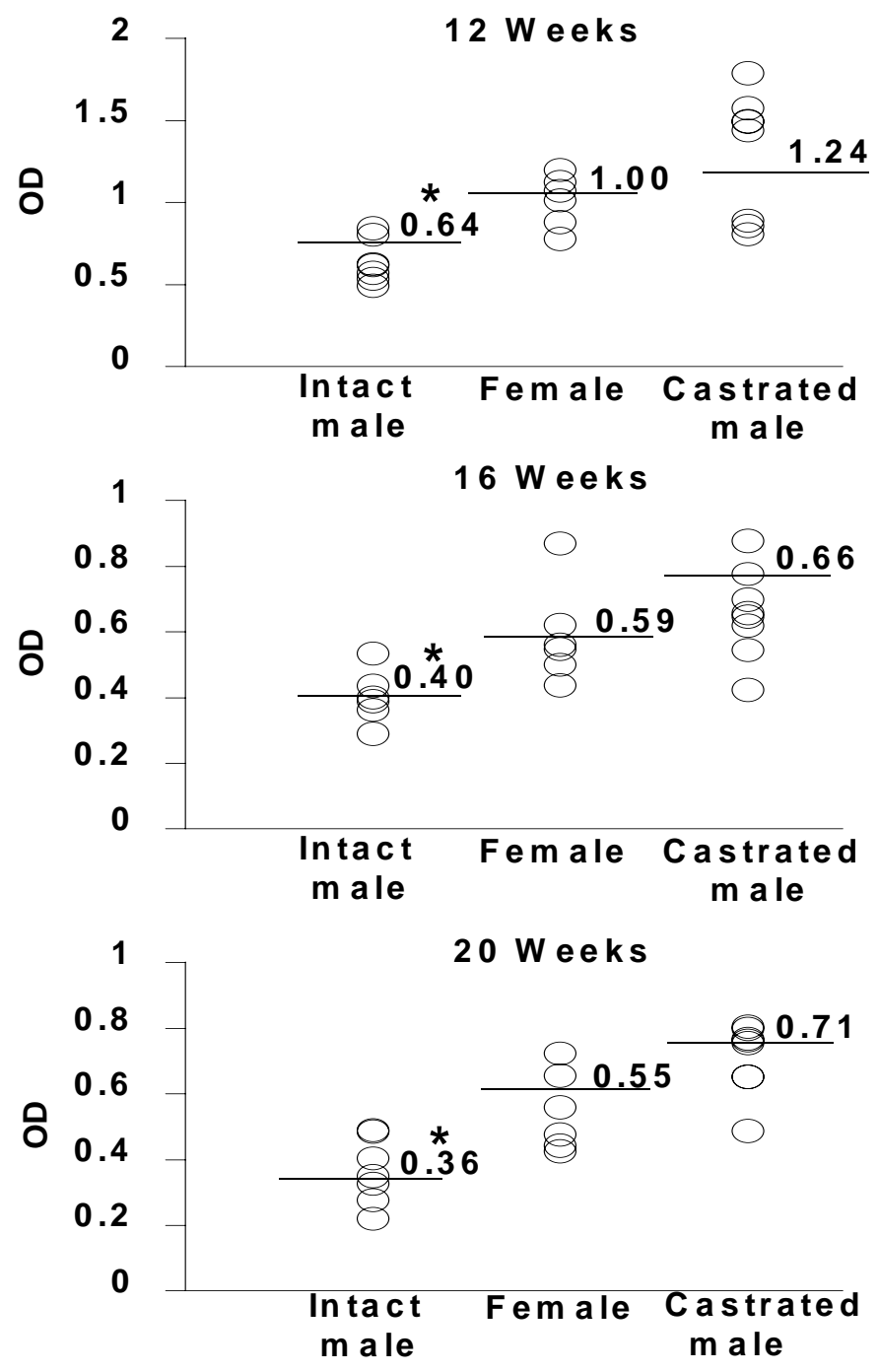

Figure 37. Castrated male mice have higher levels of serum antibodies to dsDNA than intact male controls that are comparable to those found in females. At 12-20 weeks of age, serum samples from castrated or intact NZB x NZW male mice were collected monthly and evaluated by ELISA for the appearance of IgG antibodies to dsDNA in serum. An * indicates a significant difference at $\mathrm{p}<0.05$. These experiments were performed by Jean Manirarora. 

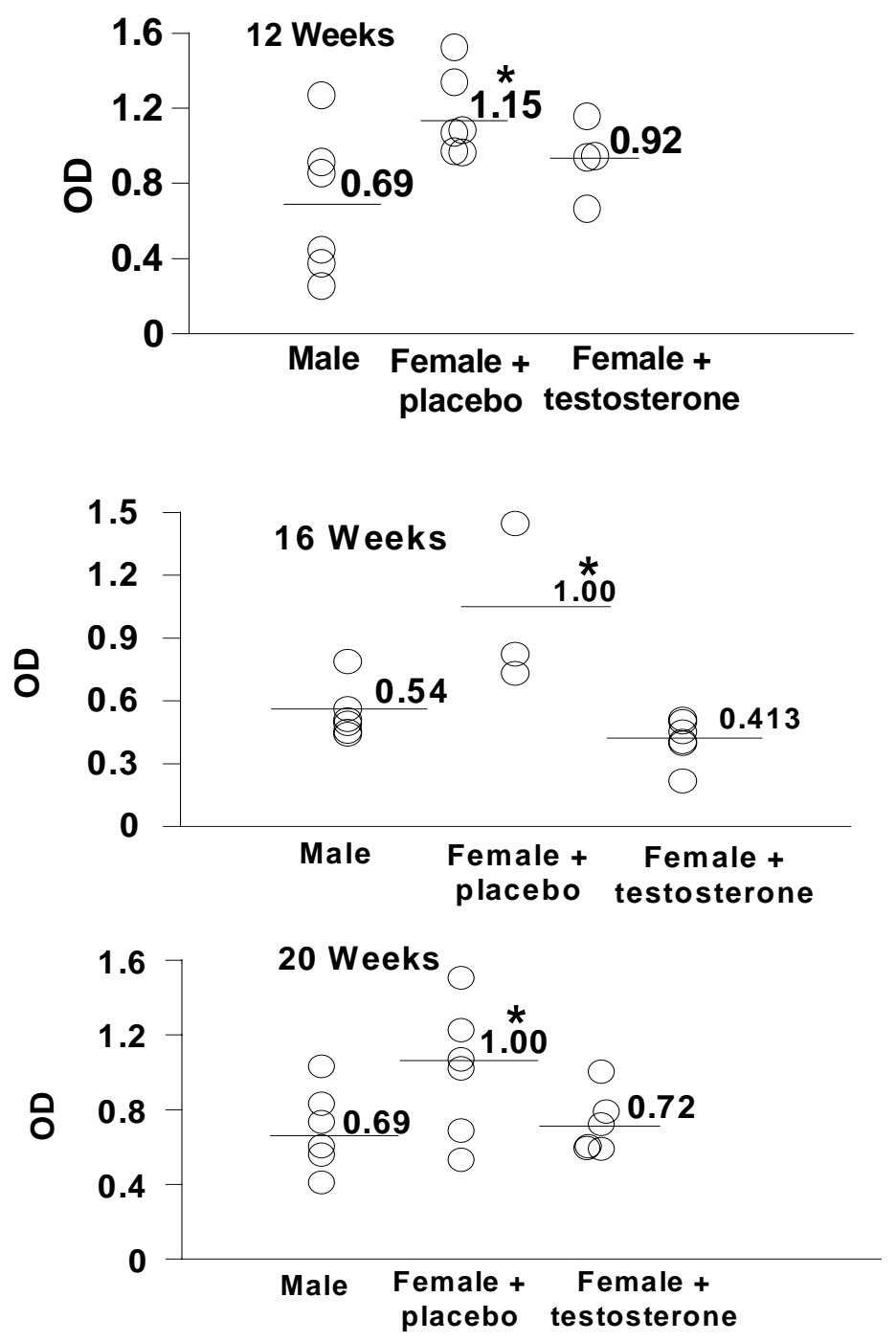

Figure 38. Androgen-treated female mice have levels of serum antibodies to dsDNA that are comparable to intact male mice, but are significantly lower than in placebo-treated female controls. At 12-20 weeks of age, serum samples from male or androgen or placebo-treated female mice were evaluated monthly by ELISA for the appearance of IgG antibodies to dsDNA in serum. An * indicates a significant difference at $\mathrm{p}<0.05$. These experiments were performed by Jean Manirarora. 
Table 11a. Analysis of the percentage of lymph node $\mathrm{CD} 4^{+} \mathrm{CD} 25^{+} \mathrm{T}$ cells in female and male NZB $x$ NZW mice.

\begin{tabular}{|c|c|c|c|c|c|c|}
\hline \multicolumn{3}{|c|}{ Exp\#1 } & \multicolumn{2}{|c|}{ Exp\#2 } & \multicolumn{2}{|c|}{ Exp\#3 } \\
\hline $\begin{array}{c}\text { NZB } \\
X \\
\text { NZW } \\
\end{array}$ & $q$ & 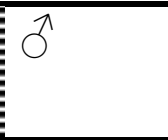 & $q$ & $\delta$ & q & $\sigma^{\lambda}$ \\
\hline 9 weeks & $\begin{array}{l}5.31 \pm \\
0.12(10)\end{array}$ & $\begin{array}{l}6.01^{*} \pm \\
0.13(10) \\
{ }^{*} p=0.001\end{array}$ & $\begin{array}{l}5.92 \pm \\
0.14(10)\end{array}$ & $\begin{array}{l}7.01^{*} \pm \\
0.42(10) \\
{ }^{*} p=0.023\end{array}$ & & \\
\hline 16 weeks & $\begin{array}{l}4.50 \pm \\
0.10(5)\end{array}$ & $\begin{array}{l}4.10 \pm \\
0.40(5) \\
p=0.274\end{array}$ & $\begin{array}{l}4.30 \pm \\
0.20(5)\end{array}$ & $\begin{array}{l}5.40^{*} \pm \\
0.20(5) \\
{ }^{*} p=0.011\end{array}$ & & \\
\hline 18 weeks & $\begin{array}{l}6.09 \pm \\
0.20(9)\end{array}$ & $\begin{array}{l}7.67^{*} \pm \\
1.05(9) \\
{ }^{*} p=0.0003\end{array}$ & & & & \\
\hline 28 weeks & $\begin{array}{l}7.49 \pm \\
0.80(4)\end{array}$ & $\begin{array}{l}7.66 \pm \\
0.361(8) \\
p=0.824\end{array}$ & $\begin{array}{l}10.15 \pm \\
0.75(8)\end{array}$ & $\begin{array}{l}8.98 \pm \\
0.35(8) \\
p=0.176\end{array}$ & $\begin{array}{l}12.0 \pm \\
0.4(10)\end{array}$ & $\begin{array}{l}11.2 \pm \\
0.61(10) \\
p=0.328\end{array}$ \\
\hline
\end{tabular}

Table 11b. Time course analysis of the percentage of blood $\mathrm{CD}^{+} \mathrm{CD}^{+} 5^{+} \mathrm{T}$ cells in female and male NZB $\mathrm{x}$ NZW mice.

$\operatorname{Exp} \# 1 \quad \operatorname{Exp} \# 2$

\begin{tabular}{|c|c|c|c|c|}
\hline $\begin{array}{c}\text { NZB } \\
\text { X } \\
\text { NZW }\end{array}$ & $q$ & 0 & q & $\sigma^{\lambda}$ \\
\hline 8 weeks & $\begin{array}{l}3.9 \pm 0.2 \\
(6)\end{array}$ & $\begin{array}{l}4.9 \pm 0.2 \\
(6)\end{array}$ & $\begin{array}{l}3.33 \pm 0.4 \\
(6)\end{array}$ & $\begin{array}{l}2.73 \pm 0.3 \\
(6)\end{array}$ \\
\hline 12 weeks & $\begin{array}{l}2.80 \pm 0.2 \\
(6)\end{array}$ & $\begin{array}{l}3.00 \pm 0.2 \\
\text { (6) }\end{array}$ & $\begin{array}{l}2.90 \pm 0.4 \\
(3)\end{array}$ & $\begin{array}{l}2.82 \pm 0.2 \\
(6)\end{array}$ \\
\hline
\end{tabular}

One million cells from lymph nodes (Table 11a) or blood (Table 11b) from female versus male NZB x NZW mice of varying ages were labeled with anti-CD4 and anti-CD25 antibodies and analyzed by $\mathrm{FACS}^{\circledR}$. Stained $\mathrm{CD} 4^{+} \mathrm{T}$ cells were gated and analyzed for the expression of the CD25 surface marker, and the percentage of $\mathrm{CD}^{+} \mathrm{T}$ cells that expressed $\mathrm{CD} 25^{+}$. Data were analyzed by student's t test. An * indicates a significant difference at $\mathrm{p}<0.05$. 
Table 12a. Analysis of the percentage of lymph node $\mathrm{CD}^{+} \mathrm{CD}^{2} 5^{+} \mathrm{CD}_{103}{ }^{+}$ $T$ cells in female and male NZB $x$ NZW mice.

\begin{tabular}{|c|c|c|c|c|c|c|c|c|}
\hline & \multicolumn{3}{|c|}{ Exp\#1 } & \multicolumn{2}{|c|}{ Exp\#2 } & \multicolumn{3}{|c|}{ Exp\#3 } \\
\hline $\begin{array}{c}\text { NZB } \\
X \\
\text { NZW }\end{array}$ & $\begin{array}{l}\text { Sick } \\
q\end{array}$ & $\begin{array}{l}\text { Non-sick } \\
\text { ㅇ }\end{array}$ & $\begin{array}{l}\text { Non-sick } \\
0\end{array}$ & $\begin{array}{l}\text { Non-sick } \\
+\end{array}$ & $\begin{array}{l}\text { Non-sick } \\
0\end{array}$ & $\begin{array}{l}\text { Sick } \\
+\end{array}$ & $\begin{array}{l}\text { Non-sick } \\
+\end{array}$ & $\begin{array}{l}\text { Non-sick } \\
\lambda\end{array}$ \\
\hline 9 weeks & & $\begin{array}{l}13.40 \pm \\
0.25(10)\end{array}$ & $\begin{array}{l}20.80^{*} \pm \\
0.73(10) \\
{ }^{*} p<0.0001\end{array}$ & $\begin{array}{l}13.98 \pm \\
0.60(10)\end{array}$ & $\begin{array}{l}14.10 \pm \\
0.87(10) \\
p=0.99\end{array}$ & & & \\
\hline 16 weeks & & $\begin{array}{l}13.8 \pm \\
0.8(6)\end{array}$ & $\begin{array}{l}17.6^{*} \pm \\
0.8(6) \\
{ }^{*} \mathrm{p}=0.008\end{array}$ & $\begin{array}{l}8.69 \pm \\
0.43(8)\end{array}$ & $\begin{array}{l}12.60^{*} \pm \\
1.43(8) \\
{ }^{*} \mathrm{p}=0.04\end{array}$ & & & \\
\hline 18 weeks & & $\begin{array}{l}18.44 \pm \\
1.13(9)\end{array}$ & $\begin{array}{l}20.15 \pm \\
1.09(9) \\
p=0.293\end{array}$ & & & & & \\
\hline 28 weeks & $\begin{array}{l}24.22^{\star} \pm \\
1.51(4)\end{array}$ & $\begin{array}{l}11.65 \pm \\
1.21(4)\end{array}$ & $\begin{array}{l}14.29 \pm \\
0.47(8) \\
{ }^{*} p<0.0001\end{array}$ & $\begin{array}{l}17.61 \pm \\
2.26(8)\end{array}$ & $\begin{array}{l}14.29 \pm \\
0.48(8) \\
p=0.195\end{array}$ & $\begin{array}{l}20.80^{*} \pm \\
3.18(5)\end{array}$ & $\begin{array}{l}16.70 \pm \\
1.83(5)\end{array}$ & $\begin{array}{l}18.60 \pm \\
1.49(10) \\
{ }^{*} p=0.04\end{array}$ \\
\hline
\end{tabular}

Table 12b. Time course analysis of the percentage of blood $\mathrm{CD}^{+} \mathrm{CD}^{+} 5^{+} \mathrm{CD}_{103}{ }^{+} \mathrm{T}$ cells in female and male NZB $\mathrm{x}$ NZW mice.

$\operatorname{Exp} \# 1$

$\operatorname{Exp} \# 2$

\begin{tabular}{|c|c|c|c|c|}
\hline $\begin{array}{c}\text { NZB } \\
X \\
\text { NZW }\end{array}$ & 우 & 入 & 우 & $\sigma^{\lambda}$ \\
\hline 8 weeks & $\begin{array}{l}3.90 \pm 0.7 \\
\text { (6) }\end{array}$ & $\begin{array}{l}5.50^{*} \pm 1.2 \\
(6) \\
\mathrm{p}=0.041\end{array}$ & $\begin{array}{l}1.73 \pm 0.8 \\
\text { (3) }\end{array}$ & $\begin{array}{l}4.22^{*} \pm 1.2 \\
(6) \\
{ }^{*} \mathrm{p}=0.039\end{array}$ \\
\hline 12 weeks & $\begin{array}{l}9.60 \pm 0.6 \\
\text { (6) }\end{array}$ & $\begin{array}{l}18.40^{*} \pm 1.0 \\
(6) \\
{ }^{*} \mathrm{p}=0.0002\end{array}$ & $\begin{array}{l}2.50 \pm \\
\text { (1) }\end{array}$ & $\begin{array}{l}2.40 \pm 0.5 \\
(4) \\
p=0.659\end{array}$ \\
\hline
\end{tabular}

One million lymph node (Table 12a) or blood (Table 12b) from female versus male NZB x NZW mice of varying ages were labeled with anti-CD4, anti-CD25 and anti-CD103 antibodies and analyzed by FACS ${ }^{\circledR}$. Stained CD $4^{+} \mathrm{CD} 25^{+} \mathrm{T}$ cells were gated and analyzed for the expression of the CD103 surface marker, and the percentage of $\mathrm{CD} 4{ }^{+} \mathrm{CD} 25^{+} \mathrm{T}$ cells that expressed CD103. Data were analyzed by student's t test. An $*$ indicates a significant difference at $\mathrm{p}<0.05$. 
Table 13. Analysis of the percentage of CD62L, CTLA-4 and Foxp3 by lymph node $\mathrm{CD}^{+} \mathrm{CD}^{+} 5^{+} \mathrm{T}$ cells in female and male NZB x NZW mice.

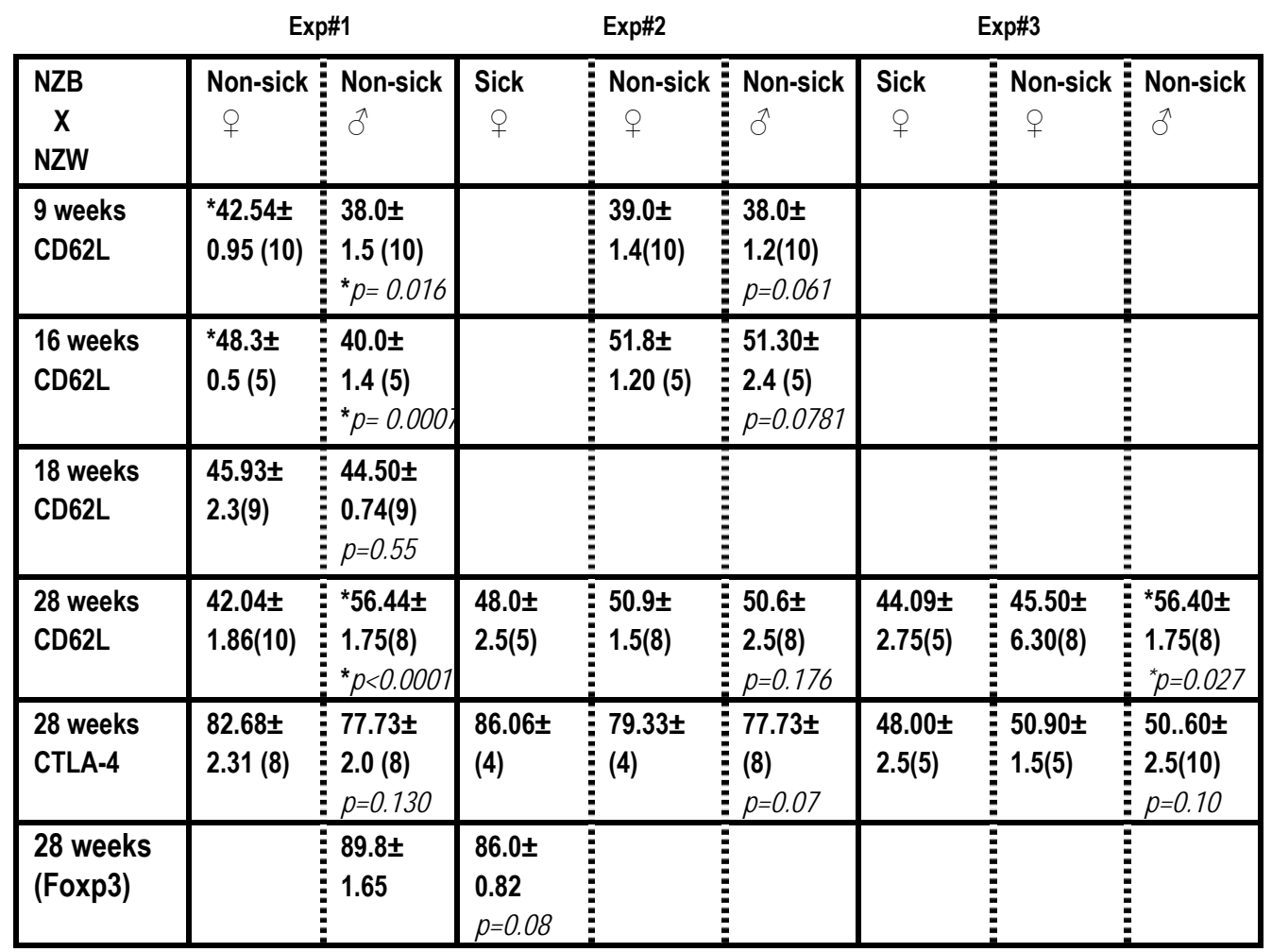

One million lymph node cells from female versus male NZB x NZW mice of varying ages were labeled with anti-CD4, -CD25, -CD62L, -CTLA-4, -Foxp3 or -CD103 antibodies and analyzed by FACS ${ }^{\circledR}$. Stained $\mathrm{CD} 4^{+} \mathrm{CD} 25^{+} \mathrm{T}$ cells were gated and analyzed for the expression of the CD62L, -CTLA-4, -Foxp3 (Table 13a) or CD103 (Table 13b) surface marker. An * indicates a significant difference at $\mathrm{p}<0.05$. 
Table 14. Analysis of the percentage of thymus $\mathrm{CD}^{+} \mathrm{CD} 25^{+}$or $\mathrm{CD}_{25}{ }^{+} \mathrm{CD} 103^{+}$ regulatory $T$ cells in female and male NZB $x$ NZW mice.

\begin{tabular}{|c|c|c|c|c|c|c|}
\hline & \multicolumn{2}{|c|}{ Exp\#1 } & \multicolumn{2}{|c|}{ Exp\#2 } & \multicolumn{2}{|c|}{ Exp\#3 } \\
\hline $\begin{array}{c}\text { NZB } \\
X \\
\text { NZW }\end{array}$ & $\begin{array}{c}\text { Non-sick } \\
+\end{array}$ & $\begin{array}{l}\text { Non-sick } \\
\hat{0}\end{array}$ & $\begin{array}{c}\text { Non-sick } \\
q \\
q\end{array}$ & $\int^{\text {Non-sick }}$ & $\begin{array}{c}\text { Non-sick } \\
\varnothing\end{array}$ & $\begin{array}{c}\text { Non-sick } \\
\hat{O}\end{array}$ \\
\hline $\mathrm{CD}^{25^{+}}$ & $\begin{array}{l}7.14 \pm \\
0.28(10)\end{array}$ & $\begin{array}{l}7.49 \pm \\
0.50(10) \\
p=0.536\end{array}$ & $\begin{array}{l}{ }^{*} 9.50 \pm \\
0.60(6)\end{array}$ & $\begin{array}{l}7.40 \pm \\
0.20(6) \\
{ }^{*} P=0.027\end{array}$ & $\begin{array}{l}* 13.58 \pm \\
1.63(10)\end{array}$ & $\begin{array}{l}7.74 \pm \\
0.74(10) \\
* P=0.004\end{array}$ \\
\hline $\mathrm{CD} 25^{+} \mathrm{CD} 103^{+}$ & $\begin{array}{l}18.3 \pm \\
0.95(10)\end{array}$ & $\begin{array}{l}16.9 \pm \\
0.47(10) \\
P=0.230\end{array}$ & $\begin{array}{l}* 29.0 \pm \\
2.4(6)\end{array}$ & $\begin{array}{l}18.3 \pm \\
0.7(6) \\
* P=0.007\end{array}$ & $\begin{array}{l}* 44.6 \pm \\
3.21(10)\end{array}$ & $\begin{array}{l}23.4 \pm \\
1.01(10) \\
* P<0.001\end{array}$ \\
\hline
\end{tabular}

One million thymus cells from female versus male NZB x NZW mice of

varying ages were labeled with anti-CD4, -CD25, -CD62L, -CTLA-4, -Foxp3 or -CD103

antibodies and analyzed by $\mathrm{FACS}{ }^{\circledR}$. Stained $\mathrm{CD} 4^{+} \mathrm{CD} 25^{+} \mathrm{T}$ cells were gated and analyzed for the expression of the CD62L, -CTLA-4, -Foxp3 (Table 14a) or CD103 (Table 14b) surface marker. An * indicates a significant difference at $\mathrm{p}<0.05$. 
Table 15a. Analysis of the absolute numbers of lymph node $\mathrm{CD}^{+} \mathrm{CD} 25^{+} \mathrm{T}$ cells in female and male NZB $x$ NZW mice.

\begin{tabular}{|c|c|c|c|c|c|c|c|c|}
\hline & & & Exp\#1 & & & Exp\#2 & & \\
\hline $\begin{array}{c}\text { NZB } \\
X \\
\text { NZW }\end{array}$ & $\begin{array}{l}\text { Sick } \\
q\end{array}$ & $\begin{array}{l}\text { Non-sick } \\
+\end{array}$ & $\begin{array}{l}\text { Non-sick } \\
\pi\end{array}$ & $\begin{array}{l}\text { Sick } \\
q\end{array}$ & $\begin{array}{l}\text { Non-sick } \\
+\end{array}$ & $\begin{array}{l}\text { Non-sick } \\
\end{array}$ & $\begin{array}{c}\text { Non-sick } \\
+\end{array}$ & $\begin{array}{l}\text { Non-sick } \\
\delta\end{array}$ \\
\hline $9-18$ weeks & & $\begin{array}{l}5.8 \times 10^{5} \\
\pm 26543(10) \\
(9 \text { weeks })\end{array}$ & $\begin{array}{l}* 8.1 \times 10^{5} \\
\pm 57097(10) \\
(9 \text { weeks }) \\
{ }^{*} p=0.04\end{array}$ & & $\begin{array}{l}6.0 \times 10^{5} \\
\pm 87654(5) \\
(16 \text { weeks) }\end{array}$ & $\begin{array}{l}* 9.0 \times 10^{5} \\
\pm 76580(5) \\
(16 \text { weeks }) \\
{ }^{*} p=0.03\end{array}$ & $\begin{array}{l}1.3 \times 10^{6} \\
\pm 9.8 \times 10^{4}(9) \\
(18 \text { weeks) }\end{array}$ & $\begin{array}{l}9.8 \times 10^{5} \\
\pm 1.5 \times 10^{5}(9) \\
(18 \text { weeks) }\end{array}$ \\
\hline 28 weeks & $\begin{array}{l}{ }^{*} 1.7 \times 10^{6} \\
\pm 6.0 \times 10^{5}(5) \\
{ }^{*} p=0.006\end{array}$ & $\begin{array}{l}4.8 \times 10^{5} \\
\pm 8.5 \times 10^{4}(10\end{array}$ & $\begin{array}{l}5.2 \times 10^{5} \\
\pm 6.1 \times 10^{4}(8)\end{array}$ & $\begin{array}{l}{ }^{*} 4.7 \times 10^{6} \\
\pm 9.7 \times 10^{5}(5) \\
{ }^{*} \mathrm{p}=0.029\end{array}$ & $\begin{array}{l}2.2 \times 10^{6} \\
\pm 5.0 \times 10^{5}(8)\end{array}$ & $\begin{array}{l}9.8 \times 10^{5} \\
\left. \pm 2.0 \times 10^{5} 8\right)\end{array}$ & & \\
\hline
\end{tabular}

Table 15b. Analysis of the absolute numbers of lymph node $\mathrm{CD} 4^{+} \mathrm{CD} 25^{+} \mathrm{CD}_{103}{ }^{+}$ $T$ cells in female and male NZB $x$ NZW mice.

\begin{tabular}{|c|c|c|c|c|c|c|}
\hline & \multicolumn{3}{|c|}{ Exp\#1 } & \multicolumn{3}{|c|}{ Exp\#2 } \\
\hline $\begin{array}{c}\text { NZB } \\
X \\
\text { NZW }\end{array}$ & $\begin{array}{l}\text { Sick } \\
+\end{array}$ & $\begin{array}{l}\text { Non-sick } \\
+\end{array}$ & $\begin{array}{l}\text { Non-sick } \\
-\end{array}$ & $\begin{array}{l}\text { Sick } \\
q\end{array}$ & $\begin{array}{l}\text { Non-sick } \\
q\end{array}$ & $\begin{array}{l}\text { Non-sick } \\
\end{array}$ \\
\hline 9 weeks & & $\begin{array}{l}0.6 \times 10^{5} \pm \\
4605(10)\end{array}$ & $\begin{array}{l}* 1.0 \times 10^{5} \pm \\
9948(10) \\
{ }^{*} p=0.016\end{array}$ & & $\begin{array}{l}6.50 \times 10^{4} \\
\pm 4605(10)\end{array}$ & $\begin{array}{l}{ }^{*} 9.50 \times 10^{4} \\
\pm 9948(10) \\
{ }^{*} p=0.0001\end{array}$ \\
\hline $16 \& 18$ weeks & & $\begin{array}{l}4.2 \times 10^{4} \\
\pm 4605(5)\end{array}$ & $\begin{array}{l}* 1.0 \times 10^{5} \\
\pm 4675(5) \\
(16 \text { weeks) } \\
{ }^{*} p=0.036\end{array}$ & & $\begin{array}{l}2.7 \times 10^{5} \\
\pm 5.2 \times 10^{4}(9)\end{array}$ & $\begin{array}{l}2.6 \times 10^{5} \\
\pm 8.8 \times 10^{4}(9) \\
(18 \text { weeks }) \\
p=0.879\end{array}$ \\
\hline 28 weeks & $\begin{array}{l}{ }^{*} 4.0 \times 10^{5} \\
\pm 1.7 \times 10^{5}(5) \\
{ }^{*} \mathrm{p}=0.006\end{array}$ & $\begin{array}{l}4.8 \times 10^{5} \\
\pm 8.5 \times 10^{4}(10)\end{array}$ & $\begin{array}{l}7.4 \times 10^{4} \\
\pm 1.1 \times 10^{4}(8)\end{array}$ & $\begin{array}{l}{ }^{*} 1.1 \times 10^{6} \\
\pm 3.5 \times 10^{5}(5) \\
{ }^{*} p=0.035\end{array}$ & $\begin{array}{l}4.0 \times 10^{5} \\
\pm 1.3 \times 10^{5}(8)\end{array}$ & $\begin{array}{l}1.9 \times 10^{5} \\
\pm 3.5 \times 10^{4}(8)\end{array}$ \\
\hline
\end{tabular}

One million lymph node cells from NZB x NZW mice of varying ages were labeled with anti-CD4, anti-CD25 and anti-CD103 antibodies and analyzed by FACS ${ }^{\circledR}$. Total numbers of $\mathrm{CD} 4^{+} \mathrm{CD} 25^{+}$(Table $15 \mathrm{a}$ ) or $\mathrm{CD} 4^{+} \mathrm{CD} 25^{+} \mathrm{CD} 103^{+}$(Table $\left.15 \mathrm{~b}\right) \mathrm{T}$ cells were then determined. Data are represented as Mean \pm SEM. Data were analyzed by student's $t$ test. An $*$ indicates a significant difference at $\mathrm{p}<0.05$. 
Table 16a. Comparison of $\mathrm{CD}^{+} \mathrm{CD} 25^{+} \mathrm{T}$ cell regulatory function between female and male NZB x NZW mice.

\begin{tabular}{|c|c|c|c|c|c|c|}
\hline Experiment & Sex / inhibition & 1:1 & $1: 2$ & $1: 4$ & $1: 8$ & 1:16 \\
\hline \multirow[b]{2}{*}{$\begin{array}{c}\text { Exp \# } 1 \\
\text { (NZB x NZW) }\end{array}$} & $\begin{array}{c}\text { (9 wks) } \\
-\end{array}$ & $6240 \pm 902$ & $10900 \pm 1660$ & $62400 \pm 11900$ & $98500 \pm 12700$ & $117000 \pm 6360$ \\
\hline & $\begin{array}{c}\sigma^{\lambda} \text { (9 wks) } \\
-\end{array}$ & $72722 \pm 793$ & $1414200 \pm 2470$ & 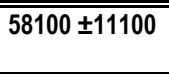 & 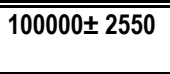 & $=120000 \pm 4930$ \\
\hline \multirow[b]{2}{*}{$\begin{array}{c}\text { Exp \# } 2 \\
\text { NZB x NZW) }\end{array}$} & $\begin{array}{c}\text { क (9 wks) } \\
-\end{array}$ & $571 \pm 67$ & $1325 \pm 96$ & $3266 \pm 38$ & $5800 \pm 267$ & $10709 \pm 76$ \\
\hline & $\begin{array}{c}\sigma^{\wedge} \text { (9 wks) } \\
-\end{array}$ & $265 \pm 31$ & $\overline{c 1497 \pm 218}$ & $2429 \pm 188$ & $5496 \pm 125$ & $111702 \pm 377$ \\
\hline
\end{tabular}

Table 16b. Comparison of $\mathrm{CD}^{+} \mathrm{CD} 25^{+} \mathrm{CD}_{103}{ }^{+} \mathrm{T}$ cell regulatory function between female and male NZB x NZW mice.

\begin{tabular}{|c|c|c|c|c|c|}
\hline Experiment & Sex / inhibition & 1:1 & $1: 2$ & $1: 4$ & $1: 8$ \\
\hline \multirow{6}{*}{$\begin{array}{c}\text { Exp \# } 1 \\
\text { (NZB x NZW) }\end{array}$} & q (9 wks) & $7990 \pm 931$ & $26400 \pm 6630$ & $70000 \pm 3140$ & $115000 \pm 831$ \\
\hline & $\begin{array}{c}\text { (9 wks) } \\
-\end{array}$ & $\bar{*} * 4240 \pm 681$ & $\bar{*} * 10800 \pm 3720$ & 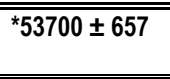 & $\overline{124000 \pm 2345}$ \\
\hline & $\begin{array}{c}+9 \text { (16 wks) } \\
\downarrow\end{array}$ & $43300 \pm 11800$ & $78600 \pm 1880$ & $101200 \pm 1160$ & $103000 \pm 1570$ \\
\hline & $\begin{array}{c}\text { of (16 wks) } \\
-\end{array}$ & *5220 \pm 1730 & "*14000 \pm 854 & "*44900 \pm 8460 & $\bar{*}{ }^{*} 51300 \pm 1370$ \\
\hline & $\begin{array}{c}+ \text { P (28 wks) } \\
\downarrow\end{array}$ & $6030 \pm 421$ & $16900 \pm 3210$ & $39100 \pm 2730$ & $45000 \pm 1670$ \\
\hline & $\begin{array}{c}\text { (28 wks) } \\
-\end{array}$ & *3320 \pm 716 & ${ }^{*} 8860 \pm 1140$ & ${ }^{*} 22800 \pm 3520$ & *38900 \pm 909 \\
\hline \multirow{6}{*}{$\begin{array}{c}\text { Exp \# } 2 \\
\text { (NZB x NZW) }\end{array}$} & $\begin{array}{c}\text { q (9 wks) } \\
-\end{array}$ & $6024 \pm 1397$ & $15601 \pm 1517$ & $22272 \pm 2690$ & $26823 \pm 2574$ \\
\hline & $\begin{array}{c}\text { (9 wks) } \\
-\end{array}$ & $5333 \pm 1142$ & $9599 \pm 1831$ & $20915 \pm 3699$ & $25860 \pm 1051$ \\
\hline & $\begin{array}{c}\text { 우 (16 wks) } \\
\downarrow\end{array}$ & $1245 \pm 75$ & $3414 \pm 111$ & $26568 \pm 1467$ & $13725 \pm 569$ \\
\hline & $\begin{array}{c}\text { o (16 wks) } \\
- \\
\end{array}$ & $\bar{*}$ *518 \pm 44 & ${ }^{*}$ *1375 \pm 142 & *3436 \pm 403 & ${ }^{*} 6688 \pm 1234$ \\
\hline & $\begin{array}{c}+ \text { (28 wks) } \\
\downarrow\end{array}$ & $2571 \pm 67$ & $4325 \pm 96$ & $8266 \pm 38$ & $17800 \pm 267$ \\
\hline & $\begin{array}{c}\text { ( }(28 \text { wks }) \\
-\end{array}$ & ${ }^{*} 65 \pm 31$ & "*1493 \pm 218 & ${ }^{*} 3429 \pm 188$ & ${ }^{*} 7496 \pm 125$ \\
\hline
\end{tabular}

$\mathrm{CD} 4{ }^{+} \mathrm{CD} 25^{+}$or $\mathrm{CD} 4{ }^{+} \mathrm{CD} 25^{+} \mathrm{CD} 103^{+}$cells were harvested from NZB x NZW mice of

varying ages, and co-cultured with $\mathrm{CD} 4^{+} \mathrm{CD} 25^{-}$responder cells in proliferation assays

to test $\mathrm{CD} 4{ }^{+} \mathrm{CD} 25^{+}$(Table $16 \mathrm{a}$ ) or $\mathrm{CD} 4^{+} \mathrm{CD} 25^{+} \mathrm{CD}_{103}{ }^{+}$(Table 16b) regulatory function.

$-=$ no difference; $\downarrow=$ inhibition by females $<$ males. Data are represented as Mean \pm SEM.

Data were analyzed by student's t test. An * indicates a significant difference at $p<0.05$. 
Table 17a. Time course analysis of the percentage of blood $\mathrm{CD}^{+} \mathrm{CD} 25^{+}$ $T$ cells in androgen-treated female NZB $x$ NZW mice.

\begin{tabular}{|c|c|c|c|c|}
\hline NZB X NZW & $\begin{array}{c}\text { Intact } \\
0 \\
0\end{array}$ & $\begin{array}{r}\begin{array}{l}\text { Intact }+ \\
+ \text { placebo }\end{array} \\
\end{array}$ & $\begin{array}{c}\text { Castrated } \\
\pi\end{array}$ & $\begin{array}{c}\text { Intact } q \\
+ \text { androgen }\end{array}$ \\
\hline $\begin{array}{l}8 \text { weeks } \\
\text { (Exp\# 1) } \\
\end{array}$ & $\begin{array}{l}5.90 \pm 0.3 \\
(6)\end{array}$ & $\begin{array}{l}3.90^{a} \pm 0.2 \\
(6)\end{array}$ & $\begin{array}{l}4.90^{\mathrm{b}} \pm 0.2 \\
(7)\end{array}$ & $\begin{array}{l}4.9^{c} \pm 0.02 \\
(6)\end{array}$ \\
\hline $\begin{array}{l}12 \text { weeks } \\
\text { (Exp\# 1) } \\
\end{array}$ & $\begin{array}{l}3.00 \pm 0.2 \\
(6)\end{array}$ & $\begin{array}{l}2.80 \pm 0.2 \\
(6)\end{array}$ & $\begin{array}{l}3.10 \pm 0.1 \\
(7)\end{array}$ & $\begin{array}{l}3.30^{c} \pm 0.1 \\
(6)\end{array}$ \\
\hline $\begin{array}{l}8 \text { weeks } \\
\text { (Exp \# 2) }\end{array}$ & $\begin{array}{l}2.73 \pm 0.3 \\
(6)\end{array}$ & $\begin{array}{l}3.33 \pm 0.4 \\
(6)\end{array}$ & $\begin{array}{l}2.83 \pm 0.2 \\
(7)\end{array}$ & $\begin{array}{l}2.50 \pm 0.2 \\
(6)\end{array}$ \\
\hline $\begin{array}{l}12 \text { weeks } \\
\text { (Exp \# 2) }\end{array}$ & $\begin{array}{l}2.82 \pm 0.2 \\
(6)\end{array}$ & $\begin{array}{l}2.90 \pm 0.4 \\
(3)\end{array}$ & $\begin{array}{l}2.80 \pm 0.1 \\
(7)\end{array}$ & $\begin{array}{l}2.40 \pm 0.5 \\
(6)\end{array}$ \\
\hline
\end{tabular}

Table 17b. Time course analysis of the percentage of blood $\mathrm{CD} 4^{+} \mathrm{CD} 25^{+} \mathrm{CD} 103^{+}$ $T$ cells in androgen-treated female NZB $x$ NZW mice.

\begin{tabular}{|l|ll|ll|}
\hline NZB X NZW & $\begin{array}{l}\text { Intact } \\
\delta\end{array}$ & $\begin{array}{c}\text { Intact } \phi \\
\text { + placebo }\end{array}$ & $\begin{array}{l}\text { Castrated } \\
\delta^{2}\end{array}$ & $\begin{array}{l}\text { Intact } q \\
\text { + androgen }\end{array}$ \\
\hline 8 weeks & $5.50 \pm 1.2$ & $3.90^{\mathrm{a}} \pm 0.7$ & $3.90^{\mathrm{b}} \pm 0.6$ & $4.45 \pm 0.8$ \\
(Exp \# 1) & $(6)$ & $(6)$ & $(6)$ & $(7)$ \\
\hline 12 weeks & $18.40 \pm 1.0$ & $9.60^{\mathrm{a}} \pm 0.6$ & $10.40^{\mathrm{b}} \pm 2.3$ & $11.10^{\mathrm{c}} \pm 0.3$ \\
(Exp \# 1) & $(6)$ & $(6)$ & $(7)$ & $(5)$ \\
\hline 8 weeks & $2.40 \pm 0.5$ & $1.73 \pm 0.8$ & $2.80 \pm 0.1$ & $2.70 \pm 0.4$ \\
(Exp \# 2) & $(4)$ & $(3)$ & $(7)$ & $(5)$ \\
\hline 12 weeks & $4.22 \pm 1.2$ & $2.50^{\mathrm{a}} \pm 0.5$ & $4.30 \pm 0.5$ & $3.71 \pm 1.3$ \\
(Exp \# 2) & $(6)$ & $(7)$ & $(7)$ & $(5)$ \\
\hline
\end{tabular}

One million cells from the blood of NZB x NZW mice of varying ages were labeled with anti-CD4, anti-CD25 and anti-CD103 antibodies and analyzed by FACS ${ }^{\circledR}$.

Percentages of $\mathrm{CD} 4^{+} \mathrm{CD} 25^{+}$(Table 17a) or $\mathrm{CD}^{+} \mathrm{CD} 25^{+} \mathrm{CD}_{103}{ }^{+}$(Table 17b)

$\mathrm{T}$ cells were then calculated using total cell counts and the results of $\mathrm{FACS}^{\circledR}$ analysis.

Data are represented as Mean \pm SEM. Data were analyzed by student's $t$ test. $\mathrm{a}=\operatorname{Intact} \hat{\delta}$ versus Intact $q+$ Placebo, $\mathrm{b}=\operatorname{Intact} \hat{\delta}$ versus Castrated $\hat{\partial}$, $\mathrm{c}=$ Intact $q+$ Placebo versus Intact $q+$ Androgen. $\mathrm{a}, \mathrm{b}, \mathrm{c}=\mathrm{p}<0.05$ 
Table 18. Comparison of $\mathrm{CD}^{+} 5^{+} \mathrm{CD}_{103}{ }^{+} \mathrm{T}$ cell regulatory function between 6 month old female and male NZB x NZW mice.

\begin{tabular}{|c|c|c|c|c|c|}
\hline Experiment & $\begin{array}{l}\text { Treatment \& } \\
\text { inhibition }\end{array}$ & $1: 2$ & $1: 4$ & $1: 8$ & 1:16 \\
\hline \multirow{4}{*}{$\begin{array}{c}\text { Exp \#1 } \\
(\mathrm{NZB} \times \mathrm{NZW})\end{array}$} & $\begin{array}{c}\text { Castrated } \delta \\
-\end{array}$ & $46200 \pm 5420$ & $56600 \pm 10800$ & $83000 \pm 5320$ & $98400 \pm 7490$ \\
\hline & $\begin{array}{c}\text { Normal } \\
\varnothing\end{array}$ & $249000 \pm 4270$ & $87500 \pm 3910$ & $99200 \pm 8050$ & $111000 \pm 4470$ \\
\hline & $\begin{array}{c}\text { Normal } q+\text { placebo } \\
\downarrow \\
\end{array}$ & $433300 \pm 11800$ & $78600 \pm 1880$ & $101000 \pm 11600$ & $1110300 \pm 1570$ \\
\hline & $\begin{array}{c}\text { Normal } q+\text { androgen } \\
-\end{array}$ & *3102 \pm 611 & "*15012 \pm 2220 & ${ }^{*}{ }^{*} 23837 \pm 296$ & *48250 413800 \\
\hline \multirow{4}{*}{$\begin{array}{c}\text { Exp \#2 } \\
\text { (NZB x NZW) }\end{array}$} & $\begin{array}{c}\text { Castrated } \bar{\delta} \\
-\end{array}$ & $30000 \pm 543$ & $63200 \pm 342$ & $122200 \pm 1345$ & $132021 \pm 674$ \\
\hline & $\begin{array}{c}\text { Normal } \bar{O} \\
-\end{array}$ & $28500 \pm 1973$ & $55432 \pm 1320$ & $119000 \pm 1130$ & $126000 \pm 104$ \\
\hline & $\begin{array}{c}\text { Normal }+ \text { + placebo } \\
\downarrow \\
\end{array}$ & $20031 \pm 985$ & $46321 \pm 1082$ & $73452 \pm 2314$ & $126389 \pm 321$ \\
\hline & $\begin{array}{c}\text { Normal }+ \text { + androgen } \\
-\end{array}$ & "*11232 \pm 500 & 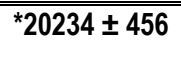 & *47325 \pm 920 & 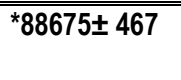 \\
\hline
\end{tabular}

$\mathrm{CD} 4^{+} \mathrm{CD} 25^{+} \mathrm{CD} 103^{+} \mathrm{T}$ cells were harvested from vehicle or androgen-treated female and intact or castrated male NZB x NZW mice at 6 months of age, and co-cultured with $\mathrm{CD} 4^{+} \mathrm{CD} 25^{-}$responder T cells in the presence of irradiated spleen cells (APC) and anti-CD 3 antibody. $\mathrm{CD} 4^{+} \mathrm{CD} 25^{+} \mathrm{CD} 103^{+}$regulatory $\mathrm{T}$ cell function was tested at various responder : regulatory cell ratios. $-=$ no difference; $\downarrow=$ inhibition by placebo-treated females $<$ androgen-treated females or intact male. Data are represented as Mean \pm SEM. Data were analyzed by student's t test. An * indicates a significant difference at $\mathrm{p}<0.05$. 
Table 19. Analysis of the percentage of $\mathrm{CD}^{+} \mathrm{CD} 25^{+}$and $\mathrm{CD}^{+} \mathrm{CD}^{+} 5^{+} \mathrm{CD} 103^{+} \mathrm{T}$ cells in lymph nodes in castrated and androgen-treated female and male NZB x NZW mice.

(a)

\begin{tabular}{|c|c|c|c|c|}
\hline $\begin{array}{c}\text { NZB } \\
X \\
\text { NZW }\end{array}$ & $\begin{array}{l}\text { Intact } \\
\hat{0}\end{array}$ & $\begin{array}{c}\text { Intact }{ }^{+} \\
\text {+ placebo }\end{array}$ & $\begin{array}{c}\text { Castrated } \\
0\end{array}$ & $\begin{array}{c}\text { Intact }+ \\
+ \text { androgen }\end{array}$ \\
\hline $\begin{array}{l}\text { CD4+CD25+ } \\
\text { (Exp \#1) }\end{array}$ & $\begin{array}{l}4.10 \pm 0.4 \\
\text { (4) }\end{array}$ & $\begin{array}{l}4.50 \pm 0.1 \\
(5)\end{array}$ & $\begin{array}{l}4.90 \pm 0.2 \\
(7)\end{array}$ & $\begin{array}{l}4.10 \pm 0.2 \\
(6)\end{array}$ \\
\hline $\begin{array}{l}\text { CD4 }{ }^{+} C D 25^{+} \\
(\operatorname{Exp} \# 2)\end{array}$ & $\begin{array}{l}5.40 \pm 0.2 \\
(10)\end{array}$ & $\begin{array}{l}4.30 \pm 0.2 \\
(10)\end{array}$ & $\begin{array}{l}5.20 \pm 0.4 \\
(10)\end{array}$ & $\begin{array}{l}4.50 \pm 0.2 \\
(10)\end{array}$ \\
\hline
\end{tabular}

(b)

\begin{tabular}{|c|c|c|c|c|}
\hline $\begin{array}{c}\text { NZB } \\
X \\
\text { NZW }\end{array}$ & $\begin{array}{c}\text { Intact } \\
0^{\lambda}\end{array}$ & $\begin{array}{r}\text { Intact } q \\
+ \text { placebo }\end{array}$ & $\begin{array}{c}\text { Castrated } \\
\pi\end{array}$ & $\begin{array}{c}\text { Intact }+ \\
+ \text { androgen }\end{array}$ \\
\hline $\begin{array}{l}\text { CD25+CD103+ } \\
\text { (Exp\#1) }\end{array}$ & $\begin{array}{l}8.8 \pm 0.4 \\
(4)\end{array}$ & $\begin{array}{l}8.69 \pm 0.4 \\
(5)\end{array}$ & $\begin{array}{l}11.5^{b} \pm 0.9 \\
(7)\end{array}$ & $\begin{array}{l}8.41 \pm 0.5 \\
(6)\end{array}$ \\
\hline $\begin{array}{l}\text { CD25+CD103+ } \\
(\text { Exp \#2) }\end{array}$ & $\begin{array}{l}17.60 \pm 0.8 \\
(10)\end{array}$ & $\begin{array}{l}13.80 \mathrm{a} \pm 0.8 \\
(10)\end{array}$ & $\begin{array}{l}14.90^{b} \pm 1.1 \\
(10)\end{array}$ & $\begin{array}{l}15.60 \pm 0.6 \\
(10)\end{array}$ \\
\hline
\end{tabular}

One million lymph node cells from 24 weeks-old female versus male NZB x NZW mice were labeled with anti-CD4, anti-CD25 and anti-CD103 antibodies and analyzed by FACS ${ }^{\circledR}$.

Stained $\mathrm{CD} 4^{+}$or $\mathrm{CD} 4^{+} \mathrm{CD} 25^{+} \mathrm{T}$ cells were respectively gated and analyzed for the expression of the $\mathrm{CD} 25$ or $\mathrm{CD} 103$ surface marker, and the percentage of $\mathrm{CD} 4{ }^{+} \mathrm{CD} 25^{+}$ or $\mathrm{CD}^{+} \mathrm{CD} 25^{+} \mathrm{CD} 103^{+}$cells were analyzed by student's $\mathrm{t}$ test.

Data are represented as Mean \pm SEM. Data were analyzed by student's $t$ test. $\mathrm{a}=\operatorname{Intact} \hat{\delta}$ versus Intact $q+$ Placebo, $\mathrm{b}=\operatorname{Intact} \hat{\partial}$ versus Castrated $\widehat{\partial} . \mathrm{a}, \mathrm{b}=\mathrm{p}<0.05$ 
Table 20. Analysis of the absolute numbers of lymph node $\mathrm{CD} 4^{+} \mathrm{CD} 25^{+}$and $\mathrm{CD}^{+} \mathrm{CD} 25^{+} \mathrm{CD} 103^{+} \mathrm{T}$ cells in lymph nodes in castrated and androgen treated female and male NZB x NZW mice.

(a)

\begin{tabular}{|c|c|c|c|c|}
\hline NZB X NZW & $\begin{array}{c}\text { Intact } \\
\hat{0}\end{array}$ & $\begin{array}{c}\text { Intact }{ }^{\circ} \\
\text { + placebo }\end{array}$ & $\begin{array}{c}\text { Castrated } \\
\hat{\delta}\end{array}$ & $\begin{array}{c}\text { Intact }+ \\
+ \text { androgen }\end{array}$ \\
\hline $\begin{array}{l}\mathrm{CD4}^{+} \mathrm{CD25}^{+} \\
(\mathrm{Exp} \# 1)\end{array}$ & $\begin{array}{l}6.3 \times 10^{5} \\
\pm 47650(4)\end{array}$ & $\begin{array}{l}\text { a } 4.2 \times 10^{5} \\
\pm 43252(5)\end{array}$ & $\begin{array}{l}7.0 \times 10^{6} \\
\pm 55432(7)\end{array}$ & $\begin{array}{l}06.6 \times 10^{5} \\
\pm 89754(6)\end{array}$ \\
\hline $\begin{array}{l}\text { CD4+CD25+ } \\
\text { (Exp \#2) }\end{array}$ & $\begin{array}{l}7.1 \times 10^{6} \\
\pm 3245(10) \\
\end{array}$ & $\begin{array}{l}5.5 \times 10^{6} \\
\pm 3214(10) \\
\end{array}$ & $\begin{array}{l}\mathrm{b} 6.1 \times 10^{6} \\
\pm 32413(10) \\
\end{array}$ & $\begin{array}{l}c 6.3 \times 10^{6} \\
\pm 43210(10)\end{array}$ \\
\hline
\end{tabular}

(b)

\begin{tabular}{|c|c|c|c|c|}
\hline NZB X NZW & $\begin{array}{l}\text { Intact } \\
\hat{0}\end{array}$ & $\begin{array}{c}\text { Intact } q \\
+ \text { placebo }\end{array}$ & $\begin{array}{c}\text { Castrated } \\
\delta\end{array}$ & $\begin{array}{c}\text { Intact } \phi \\
+ \text { androgen }\end{array}$ \\
\hline $\begin{array}{l}\text { CD25+CD103+ } \\
\text { (Exp \#1) }\end{array}$ & $\begin{array}{l}5.7 \times 10^{4} \\
\pm 7654(4)\end{array}$ & $\begin{array}{l}3.1 \times 10^{4} \\
\pm 7654 \text { (5) }\end{array}$ & $\begin{array}{l}6.1 \times 10^{5} \\
\pm 8932(7)\end{array}$ & $\begin{array}{l}{ }^{c} 5.0 \times 10^{4} \\
\pm 9932(6)\end{array}$ \\
\hline $\begin{array}{l}\mathrm{CD25}^{+} \mathrm{CD} 13^{+} \\
\text {(Exp \#2) }\end{array}$ & $\begin{array}{l}5.2 \times 10^{5} \\
\pm 6654(10)\end{array}$ & $\begin{array}{l}3.9 \times 10^{5} \\
\pm 9934(10)\end{array}$ & $\begin{array}{l}\mathrm{b} 3.5 \times 0^{5} \\
\pm 7653(10)\end{array}$ & $\begin{array}{l}\mathrm{c} 4.5 \times 10^{5} \\
\pm 4325(10)\end{array}$ \\
\hline
\end{tabular}

One million lymph node cells of 24 weeks old female versus male NZB x NZW mice were labeled with anti-CD4, anti-CD25 and anti-CD103 antibodies and analyzed by FACS $^{\circledR}$. Total numbers of $\mathrm{CD}^{+} \mathrm{CD}^{2} 5^{+}$(Table $\left.20 \mathrm{a}\right)$ or $\mathrm{CD}^{+} \mathrm{CD} 25^{+} \mathrm{CD} 103^{+}$(Table 20b) were determined. Data are represented as Mean \pm SEM. Data were analyzed by student's t test.

$\mathrm{a}=$ Intact $\hat{\sigma}$ versus Intact $q+$ Placebo, $\mathrm{b}=$ Intact $\hat{\sigma}$ versus Castrated $\hat{\partial}$, $\mathrm{c}=$ Intact $q+$ Placebo versus Intact $q+$ Androgen. $\mathrm{a}, \mathrm{b}, \mathrm{c}=\mathrm{p}<0.05$ 


\section{DISCUSSION}

$\mathrm{CD} 4{ }^{+} \mathrm{CD} 25^{+}$regulatory $\mathrm{T}$ cells play an important role in the maintenance of immunological homeostasis and self-tolerance (5) by suppressing autoreactive T cells that could potentially cause autoimmune diseases. Sex steroids have been shown to strongly influence the immune response, in general, and autoimmune diseases, in particular $(106,114-119,174,175)$. For example, females have a much higher incidence of a wide range of autoimmune diseases compared to men. For these reasons, we hypothesized that sex steroids could influence the nature of autoimmune disease through an effect on $\mathrm{CD} 4{ }^{+} \mathrm{CD} 25^{+}$regulatory $\mathrm{T}$ cell number and/or function.

We have found that androgens, but not estrogens, can, in fact, have an influence on the numbers, function and phenotype of $\mathrm{CD} 4^{+} \mathrm{CD} 25^{+} \mathrm{T}$ cells.

\section{Androgens have a dramatic direct in vivo, but not in vitro effect, on $\mathrm{CD}^{+} \mathrm{CD} 25^{+}$ regulatory cell numbers and function.}

$\mathrm{CD} 4{ }^{+} \mathrm{CD} 25^{+}$regulatory $\mathrm{T}$ cells can be found in the lymph nodes, spleen, thymus and peripheral blood (5). In the first two specific aims of this work, the in vivo or in vitro effect of dihydrotestosterone or estradiol on murine female and/or male $\mathrm{CD} 4^{+} \mathrm{CD} 25^{+}$ regulatory $\mathrm{T}$ cells was analyzed. In our preliminary studies, flow cytometric analysis revealed that adult male mice appeared to have significantly more $\mathrm{CD} 4{ }^{+} \mathrm{CD} 25^{+}$cells than 
females, unlike their pre-pubertal counterparts which showed no significant differences in the expression of $\mathrm{CD} 4{ }^{+} \mathrm{CD} 25^{+}$cells between females and males. These data suggested that the differential expression of sex steroids in adult mice may influence the levels of $\mathrm{CD} 4^{+} \mathrm{CD} 25^{+}$cells in adult mice. Since increased estrogen levels are associated with exacerbation of SLE in mice and human females $(112,189)$, it is possible that estrogen may be responsible for the observed lower percentage of $\mathrm{CD} 4^{+} \mathrm{CD} 25^{+} \mathrm{T}$ cells in females compared to males in our experiments. Alternatively, the differences in $\mathrm{CD} 4^{+} \mathrm{CD} 25^{+}$ cells in females and males could be due to an androgen-mediated increase in $\mathrm{CD} 4^{+} \mathrm{CD} 25^{+}$ cells in males. Our data strongly suggest that the latter is true: androgens increase the numbers and function of $\mathrm{CD} 4{ }^{+} \mathrm{CD} 25^{+}$cells whereas estrogen appears to have a minimal effect.

With male mice exhibiting a tendency to produce higher levels of $\mathrm{CD} 4^{+} \mathrm{CD} 25^{+} \mathrm{T}$ cells, compared with females, we further analyzed whether these cells from males are phenotypically and functionally different from female $\mathrm{CD} 4{ }^{+} \mathrm{CD} 25^{+} \mathrm{T}$ cells, by assessing the expression of various molecules such as CTLA-4, CD62L, GITR, CD45RB and CD103 that are associated with the regulatory function of $\mathrm{CD} 4{ }^{+} \mathrm{CD} 25^{+} \mathrm{T}$ cells. Interestingly, we found that a greater percentage of male $\mathrm{CD} 4{ }^{+} \mathrm{CD} 25^{+} \mathrm{T}$ cells expressed CD103, compared with females and that the mean intensity of expression of CTLA-4 by male $\mathrm{CD} 4{ }^{+} \mathrm{CD} 25^{+} \mathrm{T}$ cells was also significantly higher than that found in females. These data suggest that CD103 and CTLA-4, which are involved in the homing to inflamed tissues (190), and costimulation $(32,33)$ of $\mathrm{CD} 4{ }^{+} \mathrm{CD} 25^{+} \mathrm{T}$ cells, respectively could be differentially expressed by $\mathrm{CD} 4{ }^{+} \mathrm{CD} 25^{+} \mathrm{T}$ cells in female and male mice because of the influence of sex steroids on these cells. Thus two possibilities exist, either androgens 
could up-regulate or estrogens could down-regulate the expression of CD103 and/or CTLA-4.

Our hypothesis that sex steroids are responsible for the differences observed so far between females and males was supported by our data that showed that castration of male mice reduced the levels of $\mathrm{CD} 4^{+} \mathrm{CD} 25^{+}, \mathrm{CD} 4^{+} \mathrm{CD} 25^{+} \mathrm{CD} 103^{+}$or $\mathrm{CD} 4^{+} \mathrm{CD} 25^{+} \mathrm{CTLA}-4^{+} \mathrm{T}$ cells to levels comparable to females. This phenomenon was also observed in androgen receptor deficient mice (Tfm) which had significantly reduced $\mathrm{CD} 4{ }^{+} \mathrm{CD} 25^{+}$, $\mathrm{CD} 4^{+} \mathrm{CD} 25^{+} \mathrm{CD} 103^{+}$or $\mathrm{CD} 4^{+} \mathrm{CD} 25^{+} \mathrm{CTLA}_{-} 4^{+}$T cells compared with wild-type male mice. Moreover, levels of $\mathrm{CD} 4^{+} \mathrm{CD} 25^{+}$or $\mathrm{CD} 4^{+} \mathrm{CD} 25^{+} \mathrm{CD} 103^{+} \mathrm{T}$ cells increased in females that were treated with testosterone, to levels comparable to males, and significantly higher than levels found in normal females. Thus, castrating male mice to decrease testsosterone levels or using male mice inherently deficient in the androgen receptor led to a significant reduction in the percentages of $\mathrm{CD} 4^{+} \mathrm{CD} 25^{+}$, $\mathrm{CD} 4{ }^{+} \mathrm{CD} 25^{+} \mathrm{CD} 103^{+}$or $\mathrm{CD} 4^{+} \mathrm{CD} 25^{+} \mathrm{CTLA}-4^{+}$T cells. Furthermore, providing androgen to females increased the percentage of $\mathrm{CD} 4^{+} \mathrm{CD} 25^{+}$or $\mathrm{CD} 4^{+} \mathrm{CD} 25^{+} \mathrm{CD} 103^{+} \mathrm{T}$ cells to levels found in males.

In our studies, we also observed that Foxp3, which is a specific marker for regulatory activity (78) and is essential for the development and function of $\mathrm{CD} 4{ }^{+} \mathrm{CD} 25^{+}$ regulatory cells $(81,82)$ was expressed significantly more in male $\mathrm{CD} 4{ }^{+} \mathrm{CD} 25^{+} \mathrm{CD} 103^{+} \mathrm{T}$ cells than in females, whereas with unfractionated $\mathrm{CD} 4^{+} \mathrm{CD} 25^{+} \mathrm{T}$ cells, we found no differences in Foxp3 expression between females and males. Foxp3 expression is required for suppression by $\mathrm{CD} 4^{+} \mathrm{CD} 25^{+} \mathrm{T}$ cells $(82,191)$, and recent in vivo studies have shown that decreased Foxp 3 expression levels by the $\mathrm{CD} 4^{+} \mathrm{CD} 25^{+} \mathrm{T}$ cells in the 
peripheral blood or thymocytes of multiple sclerosis or myasthenia gravis patients is quantitatively related to a reduction in functional suppression by these cells $(192,193)$. With male $\mathrm{CD} 4{ }^{+} \mathrm{CD} 25^{+} \mathrm{CD} 103^{+} \mathrm{T}$ cells in our experiments expressing more Foxp3 than females, it is possible that this differential expression of Foxp3 between the two genders correlates with functional suppression. To test this possibility, we compared the functional capacity of female and male $\mathrm{CD} 4{ }^{+} \mathrm{CD} 25^{+}$and $\mathrm{CD} 4^{+} \mathrm{CD} 25^{+} \mathrm{CD} 103^{+} \mathrm{T}$ cells. Although our results showed that both $\mathrm{CD} 4^{+} \mathrm{CD} 25^{+}$and $\mathrm{CD} 4^{+} \mathrm{CD} 25^{+} \mathrm{CD} 103^{+} \mathrm{T}$ cells from male mice suppressed the proliferation of responder $\mathrm{CD} 4^{+} \mathrm{CD} 25^{-} \mathrm{T}$ cells significantly better than those from females, the regulatory function of $\mathrm{CD} 4{ }^{+} \mathrm{CD} 25^{+} \mathrm{CD} 103^{+} \mathrm{T}$ cells was found at ratios as low as 1:1 and was more consistent than that found with the unfractionated $\mathrm{CD} 4{ }^{+} \mathrm{CD} 25^{+} \mathrm{T}$ cell regulatory cell population. Furthermore, $\mathrm{CD} 4{ }^{+} \mathrm{CD} 25^{+} \mathrm{CD} 103^{+}$, but not $\mathrm{CD} 4^{+} \mathrm{CD} 25^{+} \mathrm{T}$ cells, from intact male mice were significantly better than either castrated or Tfm male mice in suppressing $\mathrm{CD} 4^{+} \mathrm{CD} 25^{-} \mathrm{T}$ cells in vitro. These data indicated that the $\mathrm{CD} 103$ expressing fraction of $\mathrm{CD} 4^{+} \mathrm{CD} 25^{+} \mathrm{T}$ cells, particularly in males is more potent than the unfractionated $\mathrm{CD} 4^{+} \mathrm{CD} 25^{+} \mathrm{T}$ cells. CD103 ( $\alpha_{E} \beta_{7}$ intergrin) which recognizes epithelial cadherin (E-cadherin) is involved in the homing of regulatory $\mathrm{T}$ cells to sites of inflammation. In light of our experimental results, we hypothesize that males might be less susceptible to autoimmune disease because they have more $\mathrm{CD} 4^{+} \mathrm{CD} 25^{+} \mathrm{CD} 103^{+}$regulatory cells that can reach inflamed tissues, than females, and in addition, these cells are more potent at suppressing cell proliferation than those found in females. In support of this hypothesis, a recent study in experimental autoimmune encephalomyelitis (EAE) prone mice reported that male $\mathrm{CD} 4{ }^{+} \mathrm{CD} 25^{+}$regulatory $\mathrm{T}$ cells appear to control the expansion of autoreactive cells more 
effectively than those of females which may contribute to the resistance of males to EAE (194).

Our results indicate that androgens have a strong effect on both $\mathrm{CD} 4^{+} \mathrm{CD} 25^{+}$cell numbers and function. However, we do not know whether androgen affects these cells directly or, at which stage in their development. By treating regulatory $\mathrm{T}$ cells in vitro with testosterone, we found no evidence that androgens have a direct effect on peripheral mature $\mathrm{CD} 4{ }^{+} \mathrm{CD} 25^{+}$regulatory $\mathrm{T}$ cells, at least as determined by in vitro assays. Since androgens do not appear to have a direct effect on mature $\mathrm{CD} 4{ }^{+} \mathrm{CD} 25^{+}$regulatory cells, the other possibilities are either that they can affect these cells directly at an earlier stage in their development (i.e., precursor thymocyte or mature thymocyte stage) or at the level of the thymic environment itself (i.e., thymic epithelium). The latter is a possibility because all $\mathrm{T}$ cells, including the $\mathrm{CD} 4^{+} \mathrm{CD} 25^{+}$cells, require intimate contact with the thymic epithelium for normal selection and development.

We used radiation chimeras to determine whether androgens affected bone marrowderived precursors of $\mathrm{CD} 4{ }^{+} \mathrm{CD} 25^{+}$cells or the thymic epithelium, and evaluated the effects of androgens on $\mathrm{CD} 4^{+} \mathrm{CD} 25^{+}$cell numbers and function. Interestingly, we found that androgens had different effects on the two different compartments. Androgens appear to affect $\mathrm{CD} 4^{+} \mathrm{CD} 25^{+}$function by a direct influence on the bone marrow, or hematopoietic, compartment, since our results show that regulatory function is enhanced only in mice that have received wild-type, and not androgen receptor-deficient, bone marrow and androgen treatment. However, this treatment did not affect the numbers of $\mathrm{CD} 4{ }^{+} \mathrm{CD} 25^{+}$cells. On the other hand, the thymus is apparently involved in androgenmediated increases in $\mathrm{CD} 4^{+} \mathrm{CD} 25^{+}$cells, but not their function, since mice implanted 
with wild-type, and not androgen receptor-deficient, thymus exhibited increases in these cells, but not an increase in function. As mentioned above, $\mathrm{CD} 4{ }^{+} \mathrm{CD} 25^{+}$cells develop primarily in the thymus and the thymic epithelium expresses significant levels of androgen receptor, therefore, the androgens most likely affect the percentage of $\mathrm{CD} 4^{+} \mathrm{CD} 25^{+}$cells through the thymic epithelium. These data are supported by well established findings that thymus weight, cellularity and cellular composition are very sensitive to changes in androgen status, and that thymic epithelial expression of androgen receptor is required for androgen effects on thymocyte development (146). Moreover, previous studies to investigate the effects of androgens on the development of lymphocytes in the thymus and bone marrow using bone-marrow chimeras, indicated that thymic epithelial cells are mediators of androgenic effects on immature lymphocytes (150). Contrary to the results obtained with androgens, we have found that estrogens had very little effect on regulatory $\mathrm{T}$ cell numbers, phenotype or function. Our experiments concerning the estrous cycle indicated that $\mathrm{CD} 4^{+} \mathrm{CD} 25^{+}$cells from female mice in diestrus (low estrogen levels) were very slightly better at inhibiting the proliferation of responder T cells, compared with $\mathrm{CD} 4^{+} \mathrm{CD} 25^{+}$cells from female mice in proestrus (high estrogen levels). In experiments where $\mathrm{CD} 4{ }^{+} \mathrm{CD} 25^{+}$cells were directly treated with estradiol in vitro, we found no differences in proliferation between $\mathrm{CD} 4^{+} \mathrm{CD} 25^{+}$cells treated with estradiol or vehicle controls suggesting that estradiol does not directly affect mature $\mathrm{CD} 4^{+} \mathrm{CD} 25^{+}$cells. Like androgens, thymic epithelial cell expression of estrogen receptor is necessary for normal thymus development $(127,195)$. However, studies have shown that treatment of mice with low to high doses of estradiol, corresponding to levels found in estrus and pregnancy, promotes proinflammatory (Th1) cell responses in vivo 
(196) and also that estrogen prevents early T cell development in the thymus, with a dramatic reduction of thymus size and cellularity (197). Thus unlike androgens, estrogens may exert a more negative effect on $\mathrm{CD} 4{ }^{+} \mathrm{CD} 25^{+}$regulatory $\mathrm{T}$ cells.

Overall, our current studies show that androgens, but not estrogens, have a significant positive effect on $\mathrm{CD} 4{ }^{+} \mathrm{CD} 25^{+}$regulatory cell numbers and function, and may contribute to autoimmune disease resistance in males through this mechanism.

\section{The differential expression of androgen in males compared with females may account for the dramatic sex-based differences in SLE disease incidence observed in (NZB x NZW mice) F1 mice.}

Female NZB x NZW mice spontaneously develop a lupus-like disease that resembles human SLE, which involves Th1 cells (198-200). The disease is characterized by high levels of circulating anti-DNA antibodies that are first detected at 2 months of age, and glomerulonephritis that occurs in the majority of female mice by 28 weeks of age. In our experiments, the percentage of lymph node $\mathrm{CD} 4{ }^{+} \mathrm{CD} 25^{+} \mathrm{T}$ cells that expressed $\mathrm{CD} 103$ from male mice at 9,16 , or 18 weeks was significantly higher than the percentage found in females of the same age, and these cells exhibited significantly better regulatory function. However, at 28 weeks when the female mice became sick, a higher percentage of female lymph node $\mathrm{CD} 4^{+} \mathrm{CD} 25^{+}$cells were observed to express significantly more CD103 cells, compared to males. Interestingly, sick female mice at 28 weeks generally had significantly more $\mathrm{CD} 4^{+} \mathrm{CD} 25^{+}$or $\mathrm{CD} 4^{+} \mathrm{CD} 25^{+} \mathrm{CD} 103^{+}$cells in the lymph nodes, although a large proportion of these cells had downregulated CD62L, suggesting that these $\mathrm{CD} 4^{+} \mathrm{CD} 25^{+}$cells may represent an activated phenotype. 
Our final series of experiments were designed to determine whether disease onset and progression correlated with $\mathrm{CD} 4^{+} \mathrm{CD} 25^{+}$regulatory cell number and function. Disease progression was determined by quantitative analysis of circulating levels of antiDNA antibodies at 12, 16 and 20 weeks of age. We found that females consistently produced higher levels of anti-DNA-antibodies than males which correlated with both the decreased numbers and function of $\mathrm{CD} 4^{+} \mathrm{CD} 25^{+} \mathrm{CD} 103^{+}$cells. Furthermore, castrated males also had higher levels of anti-DNA antibodies than intact males which also correlated with a decrease in the number of $\mathrm{CD} 4^{+} \mathrm{CD} 25^{+} \mathrm{CD}_{103^{+}}$cells in these mice. Conversely, androgen-treated females had significantly lower levels of anti-DNA antibodies that correlated with enhanced regulatory function by $\mathrm{CD} 4^{+} \mathrm{CD} 25^{+} \mathrm{CD} 103^{+}$ cells.

Our findings showing that decreased $\mathrm{CD} 4{ }^{+} \mathrm{CD} 25^{+}$cell number is associated with disease progression is supported by studies that the administration of anti-mouse CD25 T-cell monoclonal antibody 3 days after birth, eliminates peripheral $\mathrm{CD} 4^{+} \mathrm{CD} 25^{+} \mathrm{T}$ cells and consequently speeds up the development of glomerulonephritis during the reactive phase in autoimmune prone female NZB x NZW F 1 mice (201). Other studies have shown that the lower percentage and total number of peripheral $\mathrm{CD} 4^{+} \mathrm{CD} 25^{+} \mathrm{T}$ cells in lupus-prone NZB x NZW mice permits the development of lupus-like disease in these mice, compared to sex- and age-matched nonautoimmune-prone strains of mice (202). Furthermore, a clinical study has shown that the levels of $\mathrm{CD} 4{ }^{+} \mathrm{CD} 25^{+} \mathrm{T}$ cells in the peripheral blood of patients with systemic lupus erythematosus (SLE) are significantly decreased, compared with normal/healthy controls $(172,203)$. 
The overall findings of our studies are that: 1) androgens appear to be associated with an increase in $\mathrm{CD} 4{ }^{+} \mathrm{CD} 25^{+}$cells; 2) androgens increase the percentage of $\mathrm{CD} 4{ }^{+} \mathrm{CD} 25^{+}$cells that express the important trafficking molecule, CD103; 3) androgens increase the regulatory function of these $\mathrm{CD} 4^{+} \mathrm{CD} 25^{+} \mathrm{CD} 103^{+}$cells; and 4) these androgen- mediated changes appear to correlate with prevention of disease. Based on these observations, we tentatively conclude that androgens may mediate the differences in autoimmune disease incidence between females and males, at least partially, through an enhansive effect on $\mathrm{CD} 4^{+} \mathrm{CD} 25^{+}$cell numbers and function. 


\section{REFERENCES}

1. Nishizuka, Y., and T. Sakakura. 1969. Thymus and reproduction: sex-linked dysgenesia of the gonad after neonatal thymectomy in mice. Science 166:753.

2. Sakaguchi, S., T. Takahashi, and Y. Nishizuka. 1982. Study on cellular events in post-thymectomy autoimmune oophoritis in mice. II. Requirement of Lyt-1 cells in normal female mice for the prevention of oophoritis. Journal of Experimental Medicine 156:1577.

3. Sakaguchi, S., N. Sakaguchi, M. Asano, M. Itoh, and M. Toda. 1995. Immunologic self-tolerance maintained by activated T cells expressing IL-2 receptor alpha-chains (CD25). Breakdown of a single mechanism of self-tolerance causes various autoimmune diseases. Journal of Immunology 155:1151.

4. Piccirillo, C. A., and E. M. Shevach. 2004. Naturally-occurring CD4+CD25+ immunoregulatory $\mathrm{T}$ cells: central players in the arena of peripheral tolerance. Seminars in Immunology 16:81.

5. Sakaguchi, S. 2004. Naturally arising CD4+ regulatory t cells for immunologic self-tolerance and negative control of immune responses. Annual Review of Immunology 22:531.

6. Holm, T. L., J. Nielsen, and M. H. Claesson. 2004. CD4+CD25+ regulatory T cells: I. Phenotype and physiology. APMIS 112:629.

7. Lindley, S., C. M. Dayan, A. Bishop, B. O. Roep, M. Peakman, and T. I. Tree. 2005. Defective suppressor function in CD4(+)CD25(+) T-cells from patients with type 1 diabetes. Diabetes 54:92.

8. Itoh, M., T. Takahashi, N. Sakaguchi, Y. Kuniyasu, J. Shimizu, F. Otsuka, and S. Sakaguchi. 1999. Thymus and autoimmunity: production of CD25+CD4+ naturally anergic and suppressive $T$ cells as a key function of the thymus in maintaining immunologic self-tolerance. Journal of Immunology 162:5317. 
9. Kanamaru, F., P. Youngnak, M. Hashiguchi, T. Nishioka, T. Takahashi, S. Sakaguchi, I. Ishikawa, and M. Azuma. 2004. Costimulation via glucocorticoidinduced TNF receptor in both conventional and CD25+ regulatory CD4+ T cells. Journal of Immunology 172:7306.

10. Jordan, M. S., A. Boesteanu, A. J. Reed, A. L. Petrone, A. E. Holenbeck, M. A. Lerman, A. Naji, and A. J. Caton. 2001. Thymic selection of CD4+CD25+ regulatory $\mathrm{T}$ cells induced by an agonist self-peptide.[see comment]. Nature Immunology 2:301.

11. Picca, C. C., and A. J. Caton. 2005. The role of self-peptides in the development of CD4+ CD25+ regulatory T cells. Current Opinion in Immunology 17:131.

12. Jackson, A. L., H. Matsumoto, M. Janszen, V. Maino, A. Blidy, and S. Shye. 1990. Restricted expression of p55 interleukin 2 receptor (CD25) on normal T cells. Clinical Immunology \& Immunopathology 54:126.

13. Kanegane, H., T. Miyawaki, K. Kato, T. Yokoi, T. Uehara, A. Yachie, and N. Taniguchi. 1991. A novel subpopulation of CD45RA+CD4+ T cells expressing IL-2 receptor alpha-chain (CD25) and having a functionally transitional nature into memory cells. International Immunology 3:1349.

14. Shevach, E. M. 2000. Regulatory T cells in autoimmmunity*. Annual Review of Immunology 18:423.

15. Curotto de Lafaille, M. A., A. C. Lino, N. Kutchukhidze, and J. J. Lafaille. 2004. CD25- T cells generate CD25+Foxp3+ regulatory $\mathrm{T}$ cells by peripheral expansion. Journal of Immunology 173:7259.

16. Zelenay, S., T. Lopes-Carvalho, I. Caramalho, M. F. Moraes-Fontes, M. Rebelo, and J. Demengeot. 2005. Foxp3+ CD25-CD4 T cells constitute a reservoir of committed regulatory cells that regain CD25 expression upon homeostatic expansion. Proceedings of the National Academy of Sciences of the United States of America 102:4091.

17. Liang, S., P. Alard, Y. Zhao, S. Parnell, S. L. Clark, and M. M. Kosiewicz. 2005. Conversion of CD4+ CD25- cells into CD4+ CD25+ regulatory T cells in vivo requires $\mathrm{B} 7$ costimulation, but not the thymus. Journal of Experimental Medicine 201:127. 
18. Sakaguchi, S., N. Sakaguchi, J. Shimizu, S. Yamazaki, T. Sakihama, M. Itoh, Y. Kuniyasu, T. Nomura, M. Toda, and T. Takahashi. 2001. Immunologic tolerance maintained by CD25+CD4+ regulatory T cells: their common role in controlling autoimmunity, tumor immunity, and transplantation tolerance. Immunological Reviews 182:18.

19. Maloy, K. J., L. Salaun, R. Cahill, G. Dougan, N. J. Saunders, and F. Powrie. 2003. CD4+CD25+ T(R) cells suppress innate immune pathology through cytokine-dependent mechanisms. Journal of Experimental Medicine 197:111.

20. Wood, K. J., and S. Sakaguchi. 2003. Regulatory T cells in transplantation tolerance. Nature Reviews. Immunology 3:199.

21. Asano, M., M. Toda, N. Sakaguchi, and S. Sakaguchi. 1996. Autoimmune disease as a consequence of developmental abnormality of a $\mathrm{T}$ cell subpopulation. Journal of Experimental Medicine 184:387.

22. Malek, T. R., A. Yu, V. Vincek, P. Scibelli, and L. Kong. 2002. CD4 regulatory T cells prevent lethal autoimmunity in IL-2Rbeta-deficient mice. Implications for the nonredundant function of IL-2. Immunity 17:167.

23. Furtado, G. C., M. A. Curotto de Lafaille, N. Kutchukhidze, and J. J. Lafaille. 2002. Interleukin 2 signaling is required for CD4(+) regulatory T cell function. Journal of Experimental Medicine 196:851.

24. Stephens, L. A., and D. Mason. 2000. CD25 is a marker for CD4+ thymocytes that prevent autoimmune diabetes in rats, but peripheral $\mathrm{T}$ cells with this function are found in both CD25+ and CD25- subpopulations. Journal of Immunology 165:3105.

25. Thornton, A. M., and E. M. Shevach. 2000. Suppressor effector function of CD4+CD25+ immunoregulatory T cells is antigen nonspecific. Journal of Immunology 164:183.

26. Shevach, E. M., R. S. McHugh, C. A. Piccirillo, and A. M. Thornton. 2001. Control of T-cell activation by CD4+ CD25+ suppressor T cells. Immunological Reviews 182:58.

27. Suri-Payer, E., A. Z. Amar, A. M. Thornton, and E. M. Shevach. 1998. $\mathrm{CD} 4+\mathrm{CD} 25+\mathrm{T}$ cells inhibit both the induction and effector function of 
autoreactive T cells and represent a unique lineage of immunoregulatory cells. Journal of Immunology 160:1212.

28. Takahashi, T., Y. Kuniyasu, M. Toda, N. Sakaguchi, M. Itoh, M. Iwata, J. Shimizu, and S. Sakaguchi. 1998. Immunologic self-tolerance maintained by CD25+CD4+ naturally anergic and suppressive T cells: induction of autoimmune disease by breaking their anergic/suppressive state. International Immunology 10:1969.

29. Walker, L. S., A. Chodos, M. Eggena, H. Dooms, and A. K. Abbas. 2003. Antigen-dependent proliferation of CD4+ CD25+ regulatory T cells in vivo. Journal of Experimental Medicine 198:249.

30. Powrie, F., M. W. Leach, S. Mauze, L. B. Caddle, and R. L. Coffman. 1993. Phenotypically distinct subsets of CD4+ T cells induce or protect from chronic intestinal inflammation in C. B-17 scid mice. International Immunology 5:1461.

31. Lehmann, J., J. Huehn, M. de la Rosa, F. Maszyna, U. Kretschmer, V. Krenn, M. Brunner, A. Scheffold, and A. Hamann. 2002. Expression of the integrin alpha Ebeta 7 identifies unique subsets of CD25+ as well as CD25- regulatory T cells. Proceedings of the National Academy of Sciences of the United States of America 99:13031.

32. Takahashi, T., T. Tagami, S. Yamazaki, T. Uede, J. Shimizu, N. Sakaguchi, T. W. Mak, and S. Sakaguchi. 2000. Immunologic self-tolerance maintained by $\mathrm{CD} 25(+) \mathrm{CD} 4(+)$ regulatory $\mathrm{T}$ cells constitutively expressing cytotoxic $\mathrm{T}$ lymphocyte-associated antigen 4. Journal of Experimental Medicine 192:303.

33. Read, S., V. Malmstrom, and F. Powrie. 2000. Cytotoxic T lymphocyteassociated antigen 4 plays an essential role in the function of CD25(+)CD4(+) regulatory cells that control intestinal inflammation. Journal of Experimental Medicine 192:295.

34. Shimizu, J., S. Yamazaki, T. Takahashi, Y. Ishida, and S. Sakaguchi. 2002. Stimulation of CD25(+)CD4(+) regulatory T cells through GITR breaks immunological self-tolerance.[see comment]. Nature Immunology 3:135.

35. McHugh, R. S., M. J. Whitters, C. A. Piccirillo, D. A. Young, E. M. Shevach, M. Collins, and M. C. Byrne. 2002. CD4(+)CD25(+) immunoregulatory T cells: gene expression analysis reveals a functional role for the glucocorticoid-induced TNF receptor.[see comment]. Immunity 16:311. 
36. Gonzalez, A., I. Andre-Schmutz, C. Carnaud, D. Mathis, and C. Benoist. 2001. Damage control, rather than unresponsiveness, effected by protective DX5+ T cells in autoimmune diabetes. Nature Immunology 2:1117.

37. Read, S., S. Mauze, C. Asseman, A. Bean, R. Coffman, and F. Powrie. 1998. CD38+ CD45RB(low) CD4+ T cells: a population of T cells with immune regulatory activities in vitro. European Journal of Immunology 28:3435.

38. Singh, B., S. Read, C. Asseman, V. Malmstrom, C. Mottet, L. A. Stephens, R. Stepankova, H. Tlaskalova, and F. Powrie. 2001. Control of intestinal inflammation by regulatory T cells. Immunological Reviews 182:190.

39. Herbelin, A., J. M. Gombert, F. Lepault, J. F. Bach, and L. Chatenoud. 1998. Mature mainstream TCR alpha beta $+\mathrm{CD} 4+$ thymocytes expressing L-selectin mediate "active tolerance" in the nonobese diabetic mouse. Journal of Immunology 161:2620.

40. Allison, J. P., and M. F. Krummel. 1995. The Yin and Yang of T cell costimulation.[see comment]. Science 270:932.

41. Prud'homme, G. J. 2004. Altering immune tolerance therapeutically: the power of negative thinking. Journal of Leukocyte Biology 75:586.

42. Bluestone, J. A. 1997. Is CTLA-4 a master switch for peripheral T cell tolerance? Journal of Immunology 158:1989.

43. Haspot, F., F. Villemain, G. Laflamme, F. Coulon, D. Olive, J. Tiollier, J. P. Soulillou, and B. Vanhove. 2002. Differential effect of CD28 versus B7 blockade on direct pathway of allorecognition and self-restricted responses. Blood 99:2228.

44. Chen, W., W. Jin, N. Hardegen, K. J. Lei, L. Li, N. Marinos, G. McGrady, and S. M. Wahl. 2003. Conversion of peripheral CD4+CD25- naive T cells to CD4+CD25+ regulatory T cells by TGF-beta induction of transcription factor Foxp3. Journal of Experimental Medicine 198:1875.

45. Chambers, C. A., and J. P. Allison. 1999. Costimulatory regulation of T cell function. Current Opinion in Cell Biology 11:203.

46. Peach, R. J., J. Bajorath, W. Brady, G. Leytze, J. Greene, J. Naemura, and P. S. Linsley. 1994. Complementarity determining region 1 (CDR1)- and CDR3- 
analogous regions in CTLA-4 and CD28 determine the binding to B7-1. Journal of Experimental Medicine 180:2049.

47. Tang, Q., E. K. Boden, K. J. Henriksen, H. Bour-Jordan, M. Bi, and J. A. Bluestone. 2004. Distinct roles of CTLA-4 and TGF-beta in CD4+CD25+ regulatory T cell function. European Journal of Immunology 34:2996.

48. Zheng, S. G., J. H. Wang, J. D. Gray, H. Soucier, and D. A. Horwitz. 2004. Natural and induced CD4+CD25+ cells educate CD4+CD25- cells to develop suppressive activity: the role of IL-2, TGF-beta, and IL-10. Journal of Immunology 172:5213.

49. Nishimura, E., T. Sakihama, R. Setoguchi, K. Tanaka, and S. Sakaguchi. 2004. Induction of antigen-specific immunologic tolerance by in vivo and in vitro antigen-specific expansion of naturally arising Foxp3+CD25+CD4+ regulatory $\mathrm{T}$ cells. International Immunology 16:1189.

50. Paust, S., L. Lu, N. McCarty, and H. Cantor. 2004. Engagement of B7 on effector $\mathrm{T}$ cells by regulatory $\mathrm{T}$ cells prevents autoimmune disease. Proceedings of the National Academy of Sciences of the United States of America 101:10398.

51. Chen, M. L., M. J. Pittet, L. Gorelik, R. A. Flavell, R. Weissleder, H. von Boehmer, and K. Khazaie. 2005. Regulatory T cells suppress tumor-specific CD8 T cell cytotoxicity through TGF-beta signals in vivo. Proceedings of the National Academy of Sciences of the United States of America 102:419.

52. Vasu, C., B. S. Prabhakar, and M. J. Holterman. 2004. Targeted CTLA-4 engagement induces CD4+CD25+CTLA-4high T regulatory cells with target (allo)antigen specificity. Journal of Immunology 173:2866.

53. Bottomly, K., M. Luqman, L. Greenbaum, S. Carding, J. West, T. Pasqualini, and D. B. Murphy. 1989. A monoclonal antibody to murine CD45R distinguishes CD4 T cell populations that produce different cytokines. European Journal of Immunology 19:617.

54. Lee, W. T., X. M. Yin, and E. S. Vitetta. 1990. Functional and ontogenetic analysis of murine CD45Rhi and CD45Rlo CD4+ T cells. Journal of Immunology 144:3288. 
55. Oida, T., X. Zhang, M. Goto, S. Hachimura, M. Totsuka, S. Kaminogawa, and H. L. Weiner. 2003. CD4+CD25- T cells that express latency-associated peptide on the surface suppress CD4+CD45RBhigh-induced colitis by a TGF-beta-dependent mechanism. Journal of Immunology 170:2516.

56. Gavin, M. A., S. R. Clarke, E. Negrou, A. Gallegos, and A. Rudensky. 2002. Homeostasis and anergy of $\mathrm{CD} 4(+) \mathrm{CD} 25(+)$ suppressor T cells in vivo. Nature Immunology 3:33.

57. Piccinni, M. P., M. G. Giudizi, R. Biagiotti, L. Beloni, L. Giannarini, S. Sampognaro, P. Parronchi, R. Manetti, F. Annunziato, and C. Livi. 1995. Progesterone favors the development of human T helper cells producing Th2-type cytokines and promotes both IL-4 production and membrane CD30 expression in established Th1 cell clones. Journal of Immunology 155:128.

58. Tang, Q., K. J. Henriksen, E. K. Boden, A. J. Tooley, J. Ye, S. K. Subudhi, X. X. Zheng, T. B. Strom, and J. A. Bluestone. 2003. Cutting edge: CD28 controls peripheral homeostasis of CD4+CD25+ regulatory T cells. Journal of Immunology 171:3348.

59. Ronchetti, S., O. Zollo, S. Bruscoli, M. Agostini, R. Bianchini, G. Nocentini, E. Ayroldi, and C. Riccardi. 2004. GITR, a member of the TNF receptor superfamily, is costimulatory to mouse T lymphocyte subpopulations. European Journal of Immunology 34:613.

60. Stephens, G. L., R. S. McHugh, M. J. Whitters, D. A. Young, D. Luxenberg, B. M. Carreno, M. Collins, and E. M. Shevach. 2004. Engagement of glucocorticoidinduced TNFR family-related receptor on effector T cells by its ligand mediates resistance to suppression by CD4+CD25+ T cells. Journal of Immunology 173:5008.

61. Roncarolo, M. G., and M. K. Levings. 2000. The role of different subsets of T regulatory cells in controlling autoimmunity. Current Opinion in Immunology 12:676.

62. Nakamura, K., A. Kitani, and W. Strober. 2001. Cell contact-dependent immunosuppression by $\mathrm{CD} 4(+) \mathrm{CD} 25(+)$ regulatory $\mathrm{T}$ cells is mediated by cell surface-bound transforming growth factor beta. Journal of Experimental Medicine 194:629. 
63. Brunkow, M. E., E. W. Jeffery, K. A. Hjerrild, B. Paeper, L. B. Clark, S. A. Yasayko, J. E. Wilkinson, D. Galas, S. F. Ziegler, and F. Ramsdell. 2001. Disruption of a new forkhead/winged-helix protein, scurfin, results in the fatal lymphoproliferative disorder of the scurfy mouse. Nature Genetics 27:68.

64. Asseman, C., S. Mauze, M. W. Leach, R. L. Coffman, and F. Powrie. 1999. An essential role for interleukin 10 in the function of regulatory $\mathrm{T}$ cells that inhibit intestinal inflammation. Journal of Experimental Medicine 190:995.

65. Yamagiwa, S., J. D. Gray, S. Hashimoto, and D. A. Horwitz. 2001. A role for TGF-beta in the generation and expansion of CD4+CD25+ regulatory T cells from human peripheral blood. Journal of Immunology 166:7282.

66. Liu, H., B. Hu, D. Xu, and F. Y. Liew. 2003. CD4+CD25+ regulatory T cells cure murine colitis: the role of IL-10, TGF-beta, and CTLA4. Journal of Immunology 171:5012.

67. Nakamura, K., A. Kitani, I. Fuss, A. Pedersen, N. Harada, H. Nawata, and W. Strober. 2004. TGF-beta 1 plays an important role in the mechanism of $\mathrm{CD} 4+\mathrm{CD} 25+$ regulatory $\mathrm{T}$ cell activity in both humans and mice. Journal of Immunology 172:834.

68. Manzotti, C. N., H. Tipping, L. C. Perry, K. I. Mead, P. J. Blair, Y. Zheng, and D. M. Sansom. 2002. Inhibition of human T cell proliferation by CTLA-4 utilizes CD80 and requires CD25+ regulatory T cells. European Journal of Immunology 32:2888.

69. Green, E. A., L. Gorelik, C. M. McGregor, E. H. Tran, and R. A. Flavell. 2003. CD4+CD25+ T regulatory cells control anti-islet CD8 $+\mathrm{T}$ cells through TGFbeta-TGF-beta receptor interactions in type 1 diabetes. Proceedings of the National Academy of Sciences of the United States of America 100:10878.

70. Huber, S., C. Schramm, H. A. Lehr, A. Mann, S. Schmitt, C. Becker, M. Protschka, P. R. Galle, M. F. Neurath, and M. Blessing. 2004. Cutting edge: TGFbeta signaling is required for the in vivo expansion and immunosuppressive capacity of regulatory CD4+CD25+ T cells. Journal of Immunology 173:6526.

71. Seddon, B., and D. Mason. 1999. Regulatory T cells in the control of autoimmunity: the essential role of transforming growth factor beta and interleukin 4 in the prevention of autoimmune thyroiditis in rats by peripheral 
CD4(+)CD45RC- cells and CD4(+)CD8(-) thymocytes. Journal of Experimental Medicine 189:279.

72. Shull, M. M., I. Ormsby, A. B. Kier, S. Pawlowski, R. J. Diebold, M. Yin, R. Allen, C. Sidman, G. Proetzel, and D. Calvin. 1992. Targeted disruption of the mouse transforming growth factor-beta 1 gene results in multifocal inflammatory disease. Nature 359:693.

73. Powrie, F., J. Carlino, M. W. Leach, S. Mauze, and R. L. Coffman. 1996. A critical role for transforming growth factor-beta but not interleukin 4 in the suppression of $\mathrm{T}$ helper type 1-mediated colitis by CD45RB(low) CD4+ T cells. Journal of Experimental Medicine 183:2669.

74. Bridoux, F., A. Badou, A. Saoudi, I. Bernard, E. Druet, R. Pasquier, P. Druet, and L. Pelletier. 1997. Transforming growth factor beta (TGF-beta)-dependent inhibition of T helper cell 2 (Th2)-induced autoimmunity by self-major histocompatibility complex (MHC) class II-specific, regulatory CD4(+) T cell lines. Journal of Experimental Medicine 185:1769.

75. Gorelik, L., and R. A. Flavell. 2000. Abrogation of TGFbeta signaling in T cells leads to spontaneous $\mathrm{T}$ cell differentiation and autoimmune disease. Immunity 12:171.

76. Weiner, H. L. 2001. The mucosal milieu creates tolerogenic dendritic cells and $\mathrm{T}(\mathrm{R}) 1$ and $\mathrm{T}(\mathrm{H}) 3$ regulatory cells. Nature Immunology 2:671.

77. Fantini, M. C., C. Becker, G. Monteleone, F. Pallone, P. R. Galle, and M. F. Neurath. 2004. Cutting edge: TGF-beta induces a regulatory phenotype in CD4+CD25- T cells through Foxp3 induction and down-regulation of Smad7. Journal of Immunology 172:5149.

78. Hori, S., T. Nomura, and S. Sakaguchi. 2003. Control of regulatory T cell development by the transcription factor Foxp3.[see comment]. Science 299:1057.

79. Luo, X., H. Yang, I. S. Kim, F. Saint-Hilaire, D. A. Thomas, B. P. De, E. Ozkaynak, T. Muthukumar, W. W. Hancock, R. G. Crystal, and M. Suthanthiran. 2005. Systemic transforming growth factor-betal gene therapy induces Foxp3+ regulatory cells, restores self-tolerance, and facilitates regeneration of beta cell function in overtly diabetic nonobese diabetic mice. Transplantation 79:1091. 
80. Gambineri, E., T. R. Torgerson, and H. D. Ochs. 2003. Immune dysregulation, polyendocrinopathy, enteropathy, and X-linked inheritance (IPEX), a syndrome of systemic autoimmunity caused by mutations of FOXP3, a critical regulator of T-cell homeostasis. Current Opinion in Rheumatology 15:430.

81. Khattri, R., T. Cox, S. A. Yasayko, and F. Ramsdell. 2003. An essential role for Scurfin in CD4+CD25+ T regulatory cells.[see comment]. Nature Immunology $4: 337$.

82. Fontenot, J. D., M. A. Gavin, and A. Y. Rudensky. 2003. Foxp3 programs the development and function of CD4+CD25+ regulatory T cells.[see comment]. Nature Immunology 4:330.

83. Fontenot, J. D., J. P. Rasmussen, L. M. Williams, J. L. Dooley, A. G. Farr, and A. Y. Rudensky. 2005. Regulatory T cell lineage specification by the forkhead transcription factor foxp3. Immunity 22:329.

84. El-Asady, R., R. Yuan, K. Liu, D. Wang, R. E. Gress, P. J. Lucas, C. B. Drachenberg, and G. A. Hadley. 2005. TGF-\{beta $\}$-dependent CD103 expression by CD8(+) T cells promotes selective destruction of the host intestinal epithelium during graft-versus-host disease. Journal of Experimental Medicine 201:1647.

85. Dujardin, H. C., O. Burlen-Defranoux, L. Boucontet, P. Vieira, A. Cumano, and A. Bandeira. 2004. Regulatory potential and control of Foxp3 expression in newborn CD4+ T cells. Proceedings of the National Academy of Sciences of the United States of America 101:14473.

86. Schubert, L. A., E. Jeffery, Y. Zhang, F. Ramsdell, and S. F. Ziegler. 2001. Scurfin (FOXP3) acts as a repressor of transcription and regulates $\mathrm{T}$ cell activation. Journal of Biological Chemistry 276:37672.

87. Cameron, D. R., and G. D. Braunstein. 2005. The use of dehydroepiandrosterone therapy in clinical practice. Treatments in Endocrinology 4:95.

88. Cepek, K. L., S. K. Shaw, C. M. Parker, G. J. Russell, J. S. Morrow, D. L. Rimm, and M. B. Brenner. 1994. Adhesion between epithelial cells and T lymphocytes mediated by E-cadherin and the alpha E beta 7 integrin. Nature 372:190. 
89. Kutlesa, S., J. T. Wessels, A. Speiser, I. Steiert, C. A. Muller, and G. Klein. 2002. E-cadherin-mediated interactions of thymic epithelial cells with CD103+ thymocytes lead to enhanced thymocyte cell proliferation. Journal of Cell Science 115:4505.

90. Erle, D. J., T. Brown, D. Christian, and R. Aris. 1994. Lung epithelial lining fluid T cell subsets defined by distinct patterns of beta 7 and beta 1 integrin expression. American Journal of Respiratory Cell \& Molecular Biology 10:237.

91. Erle, D. J., and R. Pabst. 2000. Intraepithelial lymphocytes in the lung: a neglected lymphocyte population.[comment]. American Journal of Respiratory Cell \& Molecular Biology 22:398.

92. Lefrancois, L., T. A. Barrett, W. L. Havran, and L. Puddington. 1994. Developmental expression of the alpha IEL beta 7 integrin on $\mathrm{T}$ cell receptor gamma delta and T cell receptor alpha beta T cells. European Journal of Immunology 24:635.

93. Kilshaw, P. J., and S. J. Murant. 1991. Expression and regulation of beta 7(beta p) integrins on mouse lymphocytes: relevance to the mucosal immune system. European Journal of Immunology 21:2591.

94. Zelenika, D., E. Adams, S. Humm, L. Graca, S. Thompson, S. P. Cobbold, and H. Waldmann. 2002. Regulatory T cells overexpress a subset of Th2 gene transcripts. Journal of Immunology 168:1069.

95. Huehn, J., K. Siegmund, J. C. Lehmann, C. Siewert, U. Haubold, M. Feuerer, G. F. Debes, J. Lauber, O. Frey, G. K. Przybylski, U. Niesner, M. de la Rosa, C. A. Schmidt, R. Brauer, J. Buer, A. Scheffold, and A. Hamann. 2004. Developmental stage, phenotype, and migration distinguish naive- and effector/memory-like CD4+ regulatory T cells. Journal of Experimental Medicine 199:303.

96. Belkaid, Y., C. A. Piccirillo, S. Mendez, E. M. Shevach, and D. L. Sacks. 2002. CD4+CD25+ regulatory $\mathrm{T}$ cells control Leishmania major persistence and immunity. Nature 420:502.

97. Rosen, S. D. 1999. Endothelial ligands for L-selectin: from lymphocyte recirculation to allograft rejection.[comment]. American Journal of Pathology 155:1013. 
98. You, S., G. Slehoffer, S. Barriot, J. F. Bach, and L. Chatenoud. 2004. Unique role of $\mathrm{CD} 4+\mathrm{CD} 62 \mathrm{~L}+$ regulatory $\mathrm{T}$ cells in the control of autoimmune diabetes in $\mathrm{T}$ cell receptor transgenic mice. Proceedings of the National Academy of Sciences of the United States of America 101 Suppl 2:14580.

99. Szanya, V., J. Ermann, C. Taylor, C. Holness, and C. G. Fathman. 2002. The subpopulation of $\mathrm{CD} 4+\mathrm{CD} 25+$ splenocytes that delays adoptive transfer of diabetes expresses L-selectin and high levels of CCR7. Journal of Immunology 169:2461.

100. Fu, S., A. C. Yopp, X. Mao, D. Chen, N. Zhang, M. Mao, Y. Ding, and J. S. Bromberg. 2004. CD4+ CD25+ CD62+ T-regulatory cell subset has optimal suppressive and proliferative potential. American Journal of Transplantation 4:65.

101. Salomon, B., D. J. Lenschow, L. Rhee, N. Ashourian, B. Singh, A. Sharpe, and J. A. Bluestone. 2000. B7/CD28 costimulation is essential for the homeostasis of the $\mathrm{CD} 4+\mathrm{CD} 25+$ immunoregulatory $\mathrm{T}$ cells that control autoimmune diabetes. Immunity 12:431.

102. Lohr, J., B. Knoechel, S. Jiang, A. H. Sharpe, and A. K. Abbas. 2003. The inhibitory function of B7 costimulators in T cell responses to foreign and selfantigens. Nature Immunology 4:664.

103. Nakajima, A., M. Azuma, S. Kodera, S. Nuriya, A. Terashi, M. Abe, S. Hirose, T. Shirai, H. Yagita, and K. Okumura. 1995. Preferential dependence of autoantibody production in murine lupus on CD86 costimulatory molecule. European Journal of Immunology 25:3060.

104. Chakrabarti, D., B. Hultgren, and T. A. Stewart. 1996. IFN-alpha induces autoimmune $\mathrm{T}$ cells through the induction of intracellular adhesion molecule-1 and B7.2. Journal of Immunology 157:522.

105. Rao, P. E., A. L. Petrone, and P. D. Ponath. 2005. Differentiation and expansion of $\mathrm{T}$ cells with regulatory function from human peripheral lymphocytes by stimulation in the presence of TGF-\{beta\}. Journal of Immunology 174:1446.

106. Dalal, M., S. Kim, and R. R. Voskuhl. 1997. Testosterone therapy ameliorates experimental autoimmune encephalomyelitis and induces a $\mathrm{T}$ helper 2 bias in the autoantigen-specific T lymphocyte response. Journal of Immunology 159:3. 
107. Kim, S., and R. R. Voskuhl. 1999. Decreased IL-12 production underlies the decreased ability of male lymph node cells to induce experimental autoimmune encephalomyelitis. Journal of Immunology 162:5561.

108. Jansson, L., and R. Holmdahl. 1998. Estrogen-mediated immunosuppression in autoimmune diseases. Inflammation Research 47:290.

109. Korn-Lubetzki, I., E. Kahana, G. Cooper, and O. Abramsky. 1984. Activity of multiple sclerosis during pregnancy and puerperium. Annals of Neurology 16:229.

110. Birk, K., C. Ford, S. Smeltzer, D. Ryan, R. Miller, and R. A. Rudick. 1990. The clinical course of multiple sclerosis during pregnancy and the puerperium. Archives of Neurology 47:738.

111. Confavreux, C., M. Hutchinson, M. M. Hours, P. Cortinovis-Tourniaire, and T. Moreau. 1998. Rate of pregnancy-related relapse in multiple sclerosis. Pregnancy in Multiple Sclerosis Group.[see comment]. New England Journal of Medicine 339:285.

112. Whitacre, C. C., S. C. Reingold, and P. A. O'Looney. 1999. A gender gap in autoimmunity. Science 283:1277.

113. Whitacre, C. C. 2001. Sex differences in autoimmune disease. Nature Immunology 2:777.

114. Jacobson, D. L., S. J. Gange, N. R. Rose, and N. M. Graham. 1997. Epidemiology and estimated population burden of selected autoimmune diseases in the United States. Clinical Immunology \& Immunopathology 84:223.

115. Bebo, B. F., Jr., A. A. Vandenbark, and H. Offner. 1996. Male SJL mice do not relapse after induction of EAE with PLP 139-151. Journal of Neuroscience Research 45:680.

116. Bebo, B. F., Jr., J. C. Schuster, A. A. Vandenbark, and H. Offner. 1998. Gender differences in experimental autoimmune encephalomyelitis develop during the induction of the immune response to encephalitogenic peptides. Journal of Neuroscience Research 52:420. 
117. Roubinian, J. R., N. Talal, J. S. Greenspan, J. R. Goodman, and P. K. Siiteri. 1978. Effect of castration and sex hormone treatment on survival, anti-nucleic acid antibodies, and glomerulonephritis in NZB/NZW F1 mice. Journal of Experimental Medicine 147:1568.

118. Serreze, D. V., and E. H. Leiter. 1994. Genetic and pathogenic basis of autoimmune diabetes in NOD mice. Current Opinion in Immunology 6:900.

119. Voskuhl, R. R., H. Pitchekian-Halabi, A. MacKenzie-Graham, H. F. McFarland, and C. S. Raine. 1996. Gender differences in autoimmune demyelination in the mouse: implications for multiple sclerosis. Annals of Neurology 39:724.

120. Sambrook, P. N., J. A. Eisman, G. D. Champion, and N. A. Pocock. 1988. Sex hormone status and osteoporosis in postmenopausal women with rheumatoid arthritis. Arthritis \& Rheumatism 31:973.

121. Lahita, R. G., H. L. Bradlow, H. G. Kunkel, and J. Fishman. 1981. Increased 16 alpha-hydroxylation of estradiol in systemic lupus erythematosus. Journal of Clinical Endocrinology \& Metabolism 53:174.

122. Beato, M., and A. Sanchez-Pacheco. 1996. Interaction of steroid hormone receptors with the transcription initiation complex. Endocrine Reviews 17:587.

123. Chakraborty, T. R., G. Rajendren, and A. C. Gore. 2005. Expression of estrogen receptor $\{a \mid p h a\}$ in the anteroventral periventricular nucleus of hypogonadal mice. Experimental Biology \& Medicine 230:49.

124. Edwards, D. P. 2005. Regulation of signal transduction pathways by estrogen and progesterone. Annual Review of Physiology 67:335.

125. Beato, M., and J. Klug. 2000. Steroid hormone receptors: an update. Human Reproduction Update 6:225.

126. Olsen, N. J., and W. J. Kovacs. 1996. Gonadal steroids and immunity. Endocrine Reviews 17:369.

127. Staples, J. E., T. A. Gasiewicz, N. C. Fiore, D. B. Lubahn, K. S. Korach, and A. E. Silverstone. 1999. Estrogen receptor alpha is necessary in thymic development and estradiol-induced thymic alterations. Journal of Immunology 163:4168. 
128. Thurmond, T. S., F. G. Murante, J. E. Staples, A. E. Silverstone, K. S. Korach, and T. A. Gasiewicz. 2000. Role of estrogen receptor alpha in hematopoietic stem cell development and B lymphocyte maturation in the male mouse.

Endocrinology 141:2309.

129. Bellido, T., G. Girasole, G. Passeri, X. P. Yu, H. Mocharla, R. L. Jilka, A. Notides, and S. C. Manolagas. 1993. Demonstration of estrogen and vitamin D receptors in bone marrow-derived stromal cells: up-regulation of the estrogen receptor by 1,25-dihydroxyvitamin-D3. Endocrinology 133:553.

130. Cohen, J. H., L. Danel, G. Cordier, S. Saez, and J. P. Revillard. 1983. Sex steroid receptors in peripheral $T$ cells: absence of androgen receptors and restriction of estrogen receptors to OKT8-positive cells. Journal of Immunology 131:2767.

131. Gulshan, S., A. B. McCruden, and W. H. Stimson. 1990. Oestrogen receptors in macrophages. Scandinavian Journal of Immunology 31:691.

132. Haruki, Y., K. Seiki, T. Enomoto, H. Fujii, and K. Sakabe. 1983. Estrogen receptor in the "non-lymphocytes" in the thymus of the ovariectomized rat. Tokai Journal of Experimental \& Clinical Medicine 8:31.

133. Kawashima, I., K. Seiki, K. Sakabe, S. Ihara, A. Akatsuka, and Y. Katsumata. 1992. Localization of estrogen receptors and estrogen receptor-mRNA in female mouse thymus. Thymus 20:115.

134. Smithson, G., K. Medina, I. Ponting, and P. W. Kincade. 1995. Estrogen suppresses stromal cell-dependent lymphopoiesis in culture. Journal of Immunology 155:3409.

135. Stimson, W. H. 1988. Oestrogen and human T lymphocytes: presence of specific receptors in the T-suppressor/cytotoxic subset. Scandinavian Journal of Immunology 28:345.

136. Tornwall, J., A. B. Carey, R. I. Fox, and H. S. Fox. 1999. Estrogen in autoimmunity: expression of estrogen receptors in thymic and autoimmune $\mathrm{T}$ cells. Journal of Gender-Specific Medicine 2:33.

137. Mosselman, S., J. Polman, and R. Dijkema. 1996. ER beta: identification and characterization of a novel human estrogen receptor. FEBS Letters 392:49. 
138. Palaszynski, K. M., K. K. Loo, J. F. Ashouri, H. B. Liu, and R. R. Voskuhl. 2004. Androgens are protective in experimental autoimmune encephalomyelitis: implications for multiple sclerosis. Journal of Neuroimmunology 146:144.

139. Kuiper, G. G., E. Enmark, M. Pelto-Huikko, S. Nilsson, and J. A. Gustafsson. 1996. Cloning of a novel receptor expressed in rat prostate and ovary. Proceedings of the National Academy of Sciences of the United States of America 93:5925.

140. Paech, K., P. Webb, G. G. Kuiper, S. Nilsson, J. Gustafsson, P. J. Kushner, and T. S. Scanlan. 1997. Differential ligand activation of estrogen receptors ERalpha and ERbeta at AP1 sites.[see comment]. Science 277:1508.

141. Cutolo, M., and R. L. Wilder. 2000. Different roles for androgens and estrogens in the susceptibility to autoimmune rheumatic diseases. Rheumatic Diseases Clinics of North America 26:825.

142. Jansson, L., T. Olsson, and R. Holmdahl. 1994. Estrogen induces a potent suppression of experimental autoimmune encephalomyelitis and collagen-induced arthritis in mice. Journal of Neuroimmunology 53:203.

143. Kim, S., S. M. Liva, M. A. Dalal, M. A. Verity, and R. R. Voskuhl. 1999. Estriol ameliorates autoimmune demyelinating disease: implications for multiple sclerosis. Neurology 52:1230.

144. Garidou, L., S. Laffont, V. Douin-Echinard, C. Coureau, A. Krust, P. Chambon, and J. C. Guery. 2004. Estrogen receptor alpha signaling in inflammatory leukocytes is dispensable for 17beta-estradiol-mediated inhibition of experimental autoimmune encephalomyelitis. Journal of Immunology 173:2435.

145. Carlsten, H., A. Tarkowski, R. Holmdahl, and L. A. Nilsson. 1990. Oestrogen is a potent disease accelerator in SLE-prone MRL lpr/lpr mice. Clinical \& Experimental Immunology 80:467.

146. Olsen, N. J., G. Olson, S. M. Viselli, X. Gu, and W. J. Kovacs. 2001. Androgen receptors in thymic epithelium modulate thymus size and thymocyte development. Endocrinology 142:1278. 
147. Viselli, S. M., N. J. Olsen, K. Shults, G. Steizer, and W. J. Kovacs. 1995. Immunochemical and flow cytometric analysis of androgen receptor expression in thymocytes. Molecular \& Cellular Endocrinology 109:19.

148. Rosen, J. L., H. T. Tran, A. Lackey, and S. M. Viselli. 1999. Sex-related immune changes in young mice. Immunological Investigations 28:247.

149. Olsen, N. J., M. B. Watson, G. S. Henderson, and W. J. Kovacs. 1991. Androgen deprivation induces phenotypic and functional changes in the thymus of adult male mice. Endocrinology 129:2471.

150. Olsen, N. J., and W. J. Kovacs. 2001. Effects of androgens on T and B lymphocyte development. Immunologic Research 23:281.

151. Olsen, N. J., P. Zhou, H. Ong, and W. J. Kovacs. 1993. Testosterone induces expression of transforming growth factor-beta 1 in the murine thymus. Journal of Steroid Biochemistry \& Molecular Biology 45:327.

152. Fitzpatrick, F., F. Lepault, F. Homo-Delarche, J. F. Bach, and M. Dardenne. 1991. Influence of castration, alone or combined with thymectomy, on the development of diabetes in the nonobese diabetic mouse. Endocrinology 129:1382.

153. Stahl, N. I., and J. L. Decker. 1978. Androgenic status of males with systemic lupus erythematosus. Arthritis \& Rheumatism 21:665.

154. Walker, S. 2001. Modulation of hormones in the treatment of lupus. Am J Manag Care 7:S486.

155. Alarcon-Segovia, D. 2001. The future of treatment for systemic lupus erythematosus. Israel Medical Association Journal: Imaj 3:127.

156. Weinstein, Y., and Z. Berkovich. 1981. Testosterone effect on bone marrow, thymus, and suppressor T cells in the (NZB X NZW)F1 mice: its relevance to autoimmunity. Journal of Immunology 126:998.

157. Fox, H. S. 1992. Androgen treatment prevents diabetes in nonobese diabetic mice. Journal of Experimental Medicine 175:1409. 
158. Maccio, D. R., G. Calfa, and G. A. Roth. 2005. Oral testosterone in male rats and the development of experimental autoimmune encephalomyelitis.

Neuroimmunomodulation 12:246.

159. Tomassini, V., E. Onesti, C. Mainero, E. Giugni, A. Paolillo, M. Salvetti, F. Nicoletti, and C. Pozzilli. 2005. Sex hormones modulate brain damage in multiple sclerosis: MRI evidence. Journal of Neurology, Neurosurgery \& Psychiatry $76: 272$.

160. Beato, M. 1989. Gene regulation by steroid hormones. Cell 56:335.

161. AyanlarBatuman, O., A. P. Ferrero, A. Diaz, and S. A. Jimenez. 1991. Regulation of transforming growth factor-beta 1 gene expression by glucocorticoids in normal human T lymphocytes. Journal of Clinical Investigation 88:1574.

162. Sader, M. A., K. C. McGrath, M. D. Hill, K. F. Bradstock, M. Jimenez, D. J. Handelsman, D. S. Celermajer, and A. K. Death. 2005. Androgen receptor gene expression in leucocytes is hormonally regulated: implications for gender differences in disease pathogenesis. Clinical Endocrinology 62:56.

163. Viselli, S. M., S. Stanziale, K. Shults, W. J. Kovacs, and N. J. Olsen. 1995. Castration alters peripheral immune function in normal male mice. Immunology 84:337.

164. Ansar Ahmed, S., W. J. Penhale, and N. Talal. 1985. Sex hormones, immune responses, and autoimmune diseases. Mechanisms of sex hormone action. American Journal of Pathology 121:531.

165. Yao, G., and X. J. Shang. 2005. A comparison of modulation of proliferation of thymocyte by testosterone, dehydroisoandrosterone and androstenedione in vitro. Archives of Andrology 51:257.

166. Karpuzoglu-Sahin, E., R. M. Gogal, Jr., C. Hardy, P. Sponenberg, and S. A. Ahmed. 2005. Short-term administration of 17-beta estradiol to outbred male CD1 mice induces changes in the immune system, but not in reproductive organs. Immunological Investigations 34:1.

167. Medina, K. L., K. P. Garrett, L. F. Thompson, M. I. Rossi, K. J. Payne, and P. W. Kincade. 2001. Identification of very early lymphoid precursors in bone marrow and their regulation by estrogen. Nature Immunology 2:718. 
168. Sadovnick, A. D., D. Bulman, and G. C. Ebers. 1991. Parent-child concordance in multiple sclerosis.[see comment]. Annals of Neurology 29:252.

169. Smith, R., and J. W. Studd. 1992. A pilot study of the effect upon multiple sclerosis of the menopause, hormone replacement therapy and the menstrual cycle. Journal of the Royal Society of Medicine 85:612.

170. Stoll, M. L., and J. Gavalchin. 2000. Systemic lupus erythematosus-messages from experimental models. Rheumatology 39:18.

171. McMurray, R. W. a. M. W. 2003. Sex Hormones and Systemic Lupus Erythematosus: Review and Meta-Analysis. Arthritis and Rheum . 48:2100.

172. Liu, M. F., C. R. Wang, L. L. Fung, and C. R. Wu. 2004. Decreased CD4+CD25+ $\mathrm{T}$ cells in peripheral blood of patients with systemic lupus erythematosus. Scandinavian Journal of Immunology 59:198.

173. Monk, C. R., M. Spachidou, F. Rovis, E. Leung, M. Botto, R. I. Lechler, and O. A. Garden. 2005. MRL/Mp CD4+,CD25- T cells show reduced sensitivity to suppression by $\mathrm{CD} 4+, \mathrm{CD} 25+$ regulatory $\mathrm{T}$ cells in vitro: a novel defect of $\mathrm{T}$ cell regulation in systemic lupus erythematosus. Arthritis \& Rheumatism 52:1180.

174. Grossman, C. 1989. Possible underlying mechanisms of sexual dimorphism in the immune response, fact and hypothesis. Journal of Steroid Biochemistry 34:241.

175. Schuurs, A. H., and H. A. Verheul. 1990. Effects of gender and sex steroids on the immune response. Journal of Steroid Biochemistry 35:157.

176. Gallatin, W. M., I. L. Weissman, and E. C. Butcher. 1983. A cell-surface molecule involved in organ-specific homing of lymphocytes. Nature 304:30.

177. Siegelman, M. H., I. C. Cheng, I. L. Weissman, and E. K. Wakeland. 1990. The mouse lymph node homing receptor is identical with the lymphocyte cell surface marker Ly-22: role of the EGF domain in endothelial binding. Cell 61:611.

178. Gomes-Pereira, S., O. R. Rodrigues, and G. M. Santos-Gomes. 2004. Dynamics of CD62L/CD45RB CD4+ and CD8+ lymphocyte subsets in hepatic and splenic tissues during murine visceral leishmaniasis. Immunology Letters 95:63. 
179. Sakaguchi, S. 2005. Naturally arising Foxp3-expressing CD25+CD4+ regulatory $\mathrm{T}$ cells in immunological tolerance to self and non-self. Nature Immunology 6: 345

180. Smithson, G., J. F. Couse, D. B. Lubahn, K. S. Korach, and P. W. Kincade. 1998. The role of estrogen receptors and androgen receptors in sex steroid regulation of B lymphopoiesis. Journal of Immunology 161:27.

181. Bebo, B. F., Jr., E. Zelinka-Vincent, G. Adamus, D. Amundson, A. A. Vandenbark, and H. Offner. 1998. Gonadal hormones influence the immune response to PLP 139-151 and the clinical course of relapsing experimental autoimmune encephalomyelitis. Journal of Neuroimmunology 84:122.

182. Roubinian, J. R., R. Papoian, and N. Talal. 1977. Androgenic hormones modulate autoantibody responses and improve survival in murine lupus. Journal of Clinical Investigation 59:1066.

183. Roubinian, J., N. Talal, P. K. Siiteri, and J. A. Sadakian. 1979. Sex hormone modulation of autoimmunity in NZB/NZW mice. Arthritis \& Rheumatism 22:1162.

184. Melez, K. A., W. A. Boegel, and A. D. Steinberg. 1980. Therapeutic studies in New Zealand mice. VII. Successful androgen treatment of NZB/NZW F1 females of different ages. Arthritis \& Rheumatism 23:41.

185. Jiang, J. F., H. Liu, and C. X. Zhang. 2005. Sex hormones in female patients with systemic lupus erythmatosus. Zhong Nan Da Xue Bao Yi Xue Ban 30:315.

186. Suffia I, R. S., Salay G, Belkaid Y. 2005. A role for CD103 in the retention of CD4+CD25+ Treg and control of Leishmania major infection. J Immunol. 174: 5444.

187. Banz, A., A. Peixoto, C. Pontoux, C. Cordier, B. Rocha, and M. Papiernik. 2003. A unique subpopulation of $\mathrm{CD} 4+$ regulatory $\mathrm{T}$ cells controls wasting disease, IL10 secretion and T cell homeostasis. European Journal of Immunology 33:2419.

188. Walker, S. E., L. W. Keisler, C. W. Caldwell, A. B. Kier, and F. S. vom Saal. 1996. Effects of altered prenatal hormonal environment on expression of autoimmune disease in NZB/NZW mice. Environmental Health Perspectives 104 Suppl 4:815. 
189. Carlsten, H., N. Nilsson, R. Jonsson, K. Backman, R. Holmdahl, and A. Tarkowski. 1992. Estrogen accelerates immune complex glomerulonephritis but ameliorates T cell-mediated vasculitis and sialadenitis in autoimmune MRL lpr/lpr mice. Cellular Immunology 144:190.

190. Siegmund, K., M. Feuerer, C. Siewert, S. Ghani, U. Haubold, A. Dankof, V. Krenn, M. P. Schon, A. Scheffold, J. B. Lowe, A. Hamann, U. Syrbe, and J. Huehn. 2005. Migration matters: regulatory t-cell compartmentalization determines suppressice activity in vivo. Blood 1:3097.

191. Walker, M. R., D. J. Kasprowicz, V. H. Gersuk, A. Benard, M. Van Landeghen, J. H. Buckner, and S. F. Ziegler. 2003. Induction of FoxP3 and acquisition of T regulatory activity by stimulated human CD4+CD25- T cells.[see comment]. Journal of Clinical Investigation 112:1437.

192. Balandina, A., S. Lecart, P. Dartevelle, A. Saoudi, and S. Berrih-Aknin. 2005. Functional defect of regulatory CD4(+)CD25+ T cells in the thymus of patients with autoimmune myasthenia gravis. Blood 105:735.

193. Huan, J., N. Culbertson, L. Spencer, R. Bartholomew, G. G. Burrows, Y. K. Chou, D. Bourdette, S. F. Ziegler, H. Offner, and A. A. Vandenbark. 2005. Decreased Foxp3 levels in multiple sclerosis patients. J. Neurosci. Res. 1:45.

194. Reddy J, W. H., Zhang X. Illes Z, Wucherpfennig KW, Sobel RA and Kuchroo VK. 2005. CD4+CD25+ regulatory T cells contribute to gender differences in susceptibility to experimental autoiimune encephalomyelitis. J. Immunol. 175:5591.

195. Nancy, P., and S. Berrih-Aknin. 2005. Differential estrogen receptor expression in autoimmune myasthenia gravis. Endocrinology 146:2345.

196. Delpy, L., V. Douin-Echinard, L. Garidou, C. Bruand, A. Saoudi, and J. C. Guery. 2005. Estrogen enhances susceptibility to experimental autoimmune myasthenia gravis by promoting type 1-polarized immune responses. J. Immunol. 15:5050.

197. Rijhsinghani, A. G., K. Thompson, S. K. Bhatia, and T. J. Waldschmidt. 1996. Estrogen blocks early T cell development in the thymus. American Journal of Reproductive Immunology 36:269. 
198. Richards, H. B., M. Satoh, J. C. Jennette, B. P. Croker, H. Yoshida, and W. H. Reeves. 2001. Interferon-gamma is required for lupus nephritis in mice treated with the hydrocarbon oil pristane. Kidney International 60:2173.

199. Theofilopoulos, A. N., S. Koundouris, D. H. Kono, and B. R. Lawson. 2001. The role of IFN-gamma in systemic lupus erythematosus: a challenge to the Th1/Th2 paradigm in autoimmunity. Arthritis Research 3:136.

200. Pollard, K. M., P. Hultman, and D. H. Kono. 2003. Using single-gene deletions to identify checkpoints in the progression of systemic autoimmunity. Annals of the New York Academy of Sciences 987:236.

201. Hayashi, T., K. Hasegawa, and C. Adachi. 2005. Elimination of CD4+CD25+ T cell accelerates the development of glomerulonephritis during the preactive phase in autoimmune-prone female NZBxNZW F mice. Int. J. Exp. Pathol. 86:289.

202. Wu, H. Y., and N. A. Staines. 2004. A deficiency of CD4+CD25+ T cells permits the development of spontaneous lupus-like disease in mice, and can be reversed by induction of mucosal tolerance to histone peptide autoantigen. Lupus 13:192.

203. Crispin, J. C., A. Martinez, and J. Alcocer-Varela. 2003. Quantification of regulatory $\mathrm{T}$ cells in patients with systemic lupus erythematosus. Journal of Autoimmunity 21:273. 


\section{LIST OF ABBREVIATIONS}

\begin{tabular}{|c|c|}
\hline $\mathrm{APC}$ & Allophycocyanine \\
\hline APC & Antigen presenting cells \\
\hline AR & Androgen receptor \\
\hline BSA & Bovine serum albumin \\
\hline CFSE & Carboxy-fluorescein diacetate, succinimidyl ester \\
\hline CTLA-4 & Cytotoxic T-lymphocyte-associated molecule 4 \\
\hline DHEA & Dehydroepiandrostene \\
\hline DHT & Dihydrotestosterone \\
\hline dsDNA & Double-stranded deoxy-ribonucleic acid \\
\hline E2 & Estradiol \\
\hline EAE & Experimental autoimmune encephalomyelitis \\
\hline ELISA & Enzyme-linked immunosorbent assay \\
\hline ER & Estrogen receptor \\
\hline ERKO & Estrogen receptor knockout \\
\hline FACS & Fluorescence activated cell sorter \\
\hline FCS & Fetal calf serum \\
\hline FITC & Fluorescein isothiocyanate \\
\hline Foxp3 & Forkhead box P3 \\
\hline GAPDH & Glyceraldehyde-3-phosphate dehydrogenase \\
\hline
\end{tabular}




$\begin{array}{ll}\text { GITR } & \text { Glucocorticoid-induced tumor-necrosis factor receptor } \\ \text { HBSS } & \text { Hank's balanced salt solution } \\ \text { HEPES } & \text { 4-(2-hydroxyethyl)-1-piperazineethanesulfonic acid } \\ \text { HEV } & \text { High endothelial venule } \\ \text { HPLC } & \text { High Performance Liquid Chromatography } \\ \text { IFN } & \text { Interferon } \\ \text { Ig } & \text { Immunoglobulin } \\ \text { IL } & \text { Interleukin } \\ \text { IPEX } & \text { Immune dysregulation, polyendocrinopathy, enteropathy, X-linked syndrome } \\ \text { LN } & \text { Lymph node } \\ \text { MG } & \text { Myasthenia gravis } \\ \text { MHC } & \text { Major histocompatibility complex } \\ \text { mRNA } & \text { Messenger ribonucleic acid } \\ \text { MS } & \text { Multiple sclerosis } \\ \text { NOD } & \text { Non-obese diabetes } \\ \text { NZB } & \text { New Zealand black } \\ \text { NZW } & \text { New Zealand white } \\ \text { OVA } & \text { Ovalbumin } \\ \text { PBS } & \text { Phosphate-buffered saline } \\ \text { PEC } & \text { Phycoerythrin } \\ \text { Reverse transcriptase PCR }\end{array}$




$\begin{array}{ll}\text { SLE } & \text { Systemic lupus erythematosus } \\ \text { TCR } & \text { T cell receptor } \\ \text { Tfm } & \text { Testicular feminization mouse } \\ \text { TGF } \beta & \text { Transforming growth factor beta } \\ \text { TNFR } & \text { Tumor necrosis factor receptor } \\ \text { Treg } & \text { Regulatory T cell } \\ \text { nTreg } & \text { Naturally occurring regulatory T cell } \\ \text { WT } & \text { Wildtype } \\ \text { TH } & \text { T helper }\end{array}$




\section{CURRICULUM VITAE}

NAME: $\quad$ Lum Doreen Nebane-Ambe

ADDRESS: Department of Microbiology and Immunology

University of Louisville

Louisville, KY

BORN: $\quad$ October 23, 1975 in Cameroon

\section{EDUCATION/RESEARCH EXPERIENCE:}

$\underline{\text { School of Medicine, University of Louisville, KY }}$

Ph.D. Candidate in Immunology Degree Expected in December 2005

o Current dissertation research interest: Sex-based differences in regulatory T cells.

$\underline{\text { School of Medicine, University of Louisville, KY }}$

MSc. in Microbiology and Immunology August 2003

o Extensive course/research work in Advanced Immunology, Microbiology, Biochemistry and Cell Biology.

o Evaluated the role that $\mathrm{CD} 4^{+} \mathrm{CD} 25^{-}$autoreactive $\mathrm{T}$ cells and/or $\mathrm{CD} 4^{+} \mathrm{CD} 25^{+}$ regulatory $\mathrm{T}$ cells play in autoimmune disease incidence in various mouse strains.

\section{McGill University, Montreal, Canada $\quad$ September 2000-July 2001}

o One year of academic and research training in Microbiology and Immunology with a focus on characterizing the protein-DNA interactions that control DNA transposition and lytic/lysogenic switch in the transposable phage D3112 from Pseudomonas aeruginosa. 
$\underline{\text { University of Zimbabwe, Harare }}$

M.Sc. in Biotechnology

December 1998

Obtained two years of course work and practical training in:

o Basic/Advanced Microbiology and Immunology

o Microbial fermentation

o Plant Biotechnology

o Recombinant DNA technology

o Enzyme technology

University of Buea, Cameroon

B.Sc. in Microbiology (Minor in Medical Laboratory Technology) July 1996

o Extensive course work / practical training in basic Microbiology, Immunology and Molecular Biology.

o Studied basic biomedical/pharmacological procedures.

\section{PROFESSIONAL EXPERIENCE:}

$>$ University of Dschang, Cameroon

Assistant Lecturer

$1999-2000$

o Taught introductory Microbiology to freshmen undergraduate students.

o Supervised daily laboratory operations and trained undergraduate students in Microbiology techniques.

$>$ International Livestock Research Institute (ILRI) Nairobi-Kenya

Research intern

1998-1999

o Conducted thesis research at the International Livestock Research Institute (ILRI) in Nairobi Kenya.

o Identified factors derived from the haemozoan parasite, Trypanosoma congolense, which are responsible for inducing immunosuppression in infected cattle. 


\section{AWARDS:}

o University of Louisville Integrated Programs in Biomedical Sciences (IPIBS) Fellowship [2001-present].

o Canadian Commonwealth Scholarship [2000-2001]

o Dutch Government International Fellowship [1997-1998]

\section{ABSTRACTS:}

o Doreen L Nebane-Ambe, Pascale Alard, Jean N Manirarora, Michele M Kosiewicz. Sex Hormones Influence $\mathrm{CD} 4{ }^{+} \mathrm{CD} 25^{+}$Regulatory $\mathrm{T}$ Cell Numbers and Function. ICI/FOCIS 2004: W28.70

o Doreen L Nebane-Ambe, Pascale Alard, Sherry L Clark, Sarah Parnell, Michele $\mathrm{M}$ Kosiewicz. $\mathrm{CD} 4{ }^{+} \mathrm{CD} 25^{+} \mathrm{CD} 103^{+}$regulatory $\mathrm{T}$ cells may contribute to sexbased differences in autoimmune disease prevalence. AAI Meeting, San Diego, CA 2005: 251.12

\section{ORGANIZATIONS:}

o American Association of Immunology

O Science Advisory Board

o Enlisted in the 2004/2005 minority and women doctoral directory 